CARLOS AUGUSTO FERRATA

\title{
Escolas públicas em São Paulo (1960-1972)
}




\section{Escolas públicas em São Paulo (1960-1972)}




\section{Agradecimentos}

Aos meus pais e família, pelo apoio permanente.

Ao Álvaro Puntoni, mestre inconteste.

A Anália Amorim, pela delicadeza com que conduziu a orientação.

Ao César Shundi, pelas conversas maravilhosas.

A Patrícia Grimaldi, pela ajuda.

A Helena Ayoub Silva.

A Avany Ferreira e Mirela Mello e todos da FDE que contribuíram durante o processo.

A Marta Moreira.

Ao Antonio Carlos Barossi.

Aos arquitetos Paulo Mendes da Rocha, Ubyrajara Gilioli, Paulo Bastos e Décio Tozzi pelas entrevistas.

A Dulcinéia pela gentileza.

A Giana Viscardi e Michael Ruzitschka, meus músicos prediletos.

Ao Anderson Freitas, Cássia Buitoni, Eduardo Ferroni, Moracy Amaral e Pablo Hereñu pelas dicas.

A professora Giselda e a todos os diretores e diretoras das escolas visitadas.

A todos os meus colegas professores, alunos e alunas sem os quais esse trabalho não seria possível.

E finalmente à Luana pela dedicação e paciência. 


\section{Resumo}

Esse trabalho é um catálogo de onze escolas públicas projetadas no estado de São Paulo num período que se estende por pouco mais de uma década, de 1960 a 1972. Reúne projetos emblemáticos da arquitetura moderna paulistana, de autoria de Paulo Mendes da Rocha, Ubyrajara Gilioli, Paulos Bastos, Décio Tozzi, entre outros. A leitura dos projetos selecionados permite reconhecer suas raízes históricas e arquitetônicas no surgimento da escola republicana, nas conquistas pedagógicas "escolanovistas", nas escolas projetadas por Affonso Eduardo Reidy e Oscar Niemeyer, nas obras da Comissão Executiva do Convênio Escolar e, finalmente, na obra precursora do arquiteto João Batista Vilanova Artigas.

\section{Abstract}

This thesis is an analysis of eleven public schools which were projected in the state of São Paulo within a period of little more than ten years from 1960 to 1972. It gathers emblematic projects of the modern architecture of São Paulo with works by Paulo Mendes da Rocha, Ubyrajara Gilioli, Paulos Bastos and Décio Tozzi among others. A comprehensive study of these selected projects allows for an understanding of how they are historically and architectonically rooted in the emergence of public schools during the republic, in the pedagogic accomplishments of the movement of the "Escola Nova" (New School) , in the schools which were planned and executed by Affonso Eduardo Reidy and Oscar Niemeyer, in the projects of the "Comissão Executiva do Convênio Escolar" (a council which was established as a collaboration between state and community authorities), and finally, in the pioneering works of the architect João Batista Vilanova Artigas. 


\section{Sumário}

\section{Introdução}

Capítulo 1: Antecedentes Arquitetônicos.

1.1. Da Escola Republicana a Anísio Teixeira - A Transformação da Escola no Brasil.

1.2. Alguns Exemplos

1.2.1. Affonso Eduardo Reidy: Escola Infantil de Pedregulho, Rio de Janeiro, 1946

Escola Brasil Praguai, Assunção, 1952

1.2.2. Oscar Niemeyer: Escola para Meninos, Cataguases, 1946

Escola Júlia Kubitscheck, Diamantina, 1951

Capítulo 2: O Caso de São Paulo.

2.1. A Produção da Comissão Executiva do Convênio Escolar - 1949 a 1954. 
“Em cada fase da luta pela educação nacional, constróem-se escolas cuja arquitetura reflete talvez melhor do que qualquer outra categoria de edifícios, as passagens mais empolgantes de nossa cultura artística; os recursos técnicos que tivemos a disposição; as idéias culturais e estéticas dominantes; tudo condicionado a um projeto nacional de desenvolvimento. Conhecendo essas passagens pode, a arquitetura brasileira, não só valorizar corretamente os sucessos dos pontos nodais de sua história, como escolher caminhos novos". 


\section{Introdução}

O projeto de pesquisa original para esta Dissertação de Mestrado, elaborado em 2004, tinha como objetivo conceber um catálogo das escolas do IPESP (Instituto de Previdência do Estado de São Paulo) e do FECE (Fundo Estadual de Construções Escolares), realizadas durante a vigência do Plano de Ação do governo Carvalho Pinto (1959 a 1963)'.

A intenção desse apanhado era trazer a público importante acervo de edificações escolares projetadas e construídas no Estado de São Paulo, em curto espaço de tempo, contando com arquitetos (muitos deles recémformados) de fora do quadro do funcionalismo público, numa iniciativa pioneira até então. Para tanto, organizaria essas escolas por grupo de arquitetos e as redesenharia à luz dos projetos executivos originais. Entretanto, em meados de 2006, para nossa surpresa, o livro Arquitetura Escolar Paulista: anos 1950 e $1960^{2}$ foi publicado, trazendo à tona a maior parte desse acervo.

Dessa feita, revisamos o projeto original estabelecendo um recorte mais específico. Selecionamos onze escolas - todas públicas, não necessariamente projetadas para o Governo do Estado - que entendemos serem obras emblemáticas da produção do período compreendido entre 1960 e 1972. Os edifícios eleitos representam um modo peculiar e contundente de pensar a escola como equipamento público na cidade. Neles estão implícitas as conquistas adquiridas ao longo do processo histórico de enfrentamento da questão do desenho do edifício escolar no país e mais especificamente em São Paulo, suas implicações sociais, éticas e estéticas.

O objetivo dessa pesquisa é contribuir para o processo de reflexão sobre as propostas colocadas por esses projetos, entendendo que o conhecimento dessa importante passagem da história da construção escolar em São Paulo permite não só valorizar os aspectos essenciais dessa produção como vislumbrar novos caminhos para a construção da obra pública e para o papel social do arquiteto no país.

O trabalho foi dividido em três capítulos. O primeiro, intitulado "Antecedentes Arquitetônicos", é um breve

1 Plano de Ação do Governo do Estado durantre a gestão do Governador Carlos Alberto Alves de Carvalho Pinto, que envolvia uma alteração de vários setores da administração estadual. No que tange às políticas para a educação, criou o FECE (Fundo Estadual de Construções Escolares), órgão responsável pelo custeio e planejamento da expansão da rede escolar do Estado de São Paulo.

2 FERREIRA, Avany de Francisco; MELLO, Mirela Geiger de (organizadoras). Arquitetura Escolar Paulista: anos 1950 e 1960. FDE (Fundação para o Desenvolvimento da Educação),São Paulo, 2006. 
panorama sobre a escola no Brasil, suas origens, importância histórica e simbólica. Destaca a escola republicana e, principalmente, as escolas modernas paradigmáticas produzidas por dois dos maiores arquitetos brasileiros, Affonso Eduardo Reidy e Oscar Niemeyer, projetadas à luz das conquistas pedagógicas do Movimento da Escola Nova, que teve o educador Anísio Teixeira como um dos maiores expoentes.

O segundo capítulo trata do caso específico da arquitetura escolar de São Paulo e foi subdividido em três partes. A primeira delas aborda a produção de uma equipe de arquitetos, funcionários públicos, chefiados por Hélio Duarte, cujas obras revolucionaram o quadro da arquitetura paulistana ao aliar as conquistas da arquitetura moderna brasileira aos avanços obtidos no plano da educação. A segunda parte do capítulo é um breve panorama histórico das circunstâncias político-institucionais em que as escolas foram realizadas. Em seguida relacionamos três escolas desenhadas por Vilanova Artigas que, em nosso entendimento, inauguraram o processo de renovação do edifício escolar no estado de São Paulo.

O terceiro e último capítulo, "As Escolas", trata especificamente das onze obras selecionadas. Traz desenhos feitos a partir dos projetos executivos originais ${ }^{3}$, imagens fotográficas e leitura dos projetos. Seus autores são os arquitetos Paulo Mendes da Rocha (EE Prof. Antônio Vilela Júnior, 1960; EE Profa. Suely Antunes de Mello, 1961; EE Prof. Ramiro Gonzáles Fernandes, 1962; EE Goferdo Teixeira da Silva Telles, 1967; EE Presidente Roosevelt, 1968; EMEB Aluísio de Azevedo, 1972), Ubyrajara Gilioli (EE Profa. Luiza Collaço Queiroz Fonseca, 1966; EE Prof. Fausto Cardoso Figueira de Mello, 1968; EE D. José de Camargo Barros, 1969), Paulo Bastos (EMEB Mário Martins Almeida, 1966) e Décio Tozzi (EE Prof. Euclides Deslandes, 1967).

Para finalizar, o trabalho conta com um volume anexo que contém a reprodução dos projetos executivos originais das escolas relacionadas, impressos no formato do papel A4, com o intuito de enriquecer a leitura das obras e contribuir para a constituição de importante acervo de escolas públicas em São Paulo. 
Capítulo 01: Antecedentes Arquitetônicos 


\subsection{Da Escola Republicana a Anísio Teixeira - A Transformação da Escola no Brasil}

Em seu célebre Raízes do Brasil', Sérgio Buarque de Hollanda discute a diferença entre as ocupações espanhola e portuguesa na América, ressaltando na primeira a importância do traçado urbano ordenador e das obras dele decorrentes:

"A construção da cidade começaria sempre pela chamada praça maior. Quando em costa de mar essa praça ficaria no lugar do desembarque do porto; quando em zona mediterrânea, ao centro da povoação... Assim, a povoação partia nitidamente de um centro; a praça maior representa aqui o mesmo papel do cardo e do decumanos nas cidades romanas - as duas linhas traçadas pelo lituus do fundador, de norte a sul e de leste a oeste, que serviam como referência para o plano futuro da rede urbana. Mas,

ao passo que nestas o agrupamento ordenado pretende apenas reproduzir na terra a própria ordem cósmica, no plano das cidades hispano-americanas, o que se exprime é a idéia de que o homem pode intervir arbitrariamente, e com sucesso, no curso das coisas e de que a história não somente acontece, mas também pode ser dirigida e até fabricada”.²

Por outro lado, a idéia de construção da própria história por meio de uma ordenação abstrata, de uma intenção prévia de ocupação, de um projeto, não figurava nas intenções originais da coroa Portuguesa durante a ocupação de sua porção de território americano. De acordo com Sérgio Buarque de Hollanda, isso se insere dentro do espírito usurário dessa ocupação. Não interessava, portanto, aos portugueses constituir cidades nem tampouco os equipamentos dela decorrentes. Disso resultou a primazia da vida rural em relação à urbana durante mais de três séculos de ocupação portuguesa no Brasil:

"Essa primazia acentuada da vida rural concorda bem com o espírito da dominação portuguesa, que renunciou a trazer normas imperativas e absolutas, que cedeu todas as vezes em que as conveniências imediatas aconselharam a ceder, que cuidou menos em construir, planejar ou plantar alicerces, do que em feitorizar uma riqueza fácil e quase ao alcance da mão”.

Os espanhóis, por sua vez, pensavam de maneira distinta a ordenação do território e a construção das obras representativas das colônias; a construção das escolas de ensino superior, nesse sentido, refletiu sua intenção urbanizadora: 
"O afã de fazer novas terras mais do que simples feitorias comerciais levou os castelhanos, algumas vezes, a começar pela cúpula a construção do edifício colonial. Já em 1538, cria-se a Universidade de São Domingos. A de São Marcos, em Lima, com os privilégios, isenções e limitações da de Salamanca, é fundada por célula real de 1551, vintes anos apenas depois de iniciada a conquista do Peru por Francisco Pizarro. Também de 1551 é a da Cidade do México, que em 1553 inaugura seus cursos”.

Em contrapartida, no Brasil, as primeiras instalações de ensino superior datam de 1827 (cursos de Direito em São Paulo e Olinda) e a instituição escolar é um fenômeno ainda mais recente, foi implantada só a partir da República. Em São Paulo a escola nasceu na Praça da República, em substituição ao edifício da Igreja.

“ [...] Em 1894 era construída a Escola Normal de São Paulo, centro de preparação de professores, hoje Instituto de Educação

Caetano de Campos [...] O prédio da Escola Normal de São Paulo conservou-se tal qual era inicialmente até 1940. Magnífico edifício implantado em vasta área verde, simboliza bem o ímpeto renovador que caracterizou os primeiros anos republicanos. A Escola e o Relógio como que se transformaram em símbolos do ardoroso ideário republicano aparecendo nas escolas mais novas em substituição da Igreja e do Cruzeiro".

A cidade modificava-se, passava a ter um caráter nitidamente urbano, resultado direto do desenvolvimento industrial e conseqüente aumento populacional. Foi nesse contexto histórico que o Estado passou a organizar a educação do país. "[...] a escola é conseqüência da vida urbana - equipamento da cidade industrial”" ${ }^{\prime \prime}$ resume Artigas.

MARCÍLIO (2005) assim descreve o nascimento de um sistema público de ensino em São Paulo:

“Com o empenho e determinação dos intelectuais do primeiro momento da República, São Paulo realizou a sua primeira Reforma paulista da Instrução Pública, em 1892, criando um primeiro e aperfeiçoado sistema escolar, que ia do ensino primário e secundário à Escola Normal e ao superior, incluindo a criação do jardim-de-infância e do Ginásio de Estado. Foi organizada a primeira rede de ensino público estruturada e articulada no sentido vertical. Ela tornou-se o paradigma para todo o país". ${ }^{7}$

A Escola Normal de São Paulo, de 1884, batizada depois de Instituto de Educação Caetano de Campos em homenagem a seu primeiro diretor, é exemplar desse momento histórico. Este edifício ocupava extensa área

HOLLANDA, Sérgio Buarque de. Raízes do Brasil. 2005. São Paulo, Companhia das Letras, p. 98.

ARTIGAS, João Batista Vilanova. Sobre escolas... In: Acrópole n 377. São Paulo, setembro de 1970, p. 11.

Idem p.10. $137-138$.

MARCÍLIO, Maria Luiza. História da Escola em São Paulo e no Brasil. São Paulo, Imprensa Oficial do Estado de São Paulo: Instituto Barudel, 2005, p. 


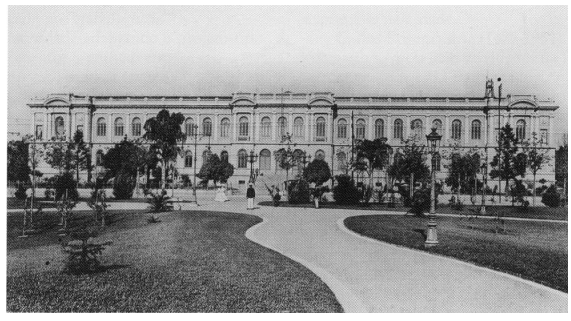

Caetano de Campos. Ramos de Azevedo, 1884.

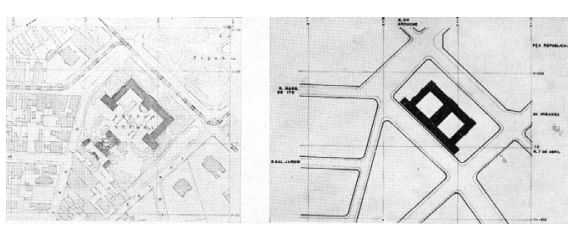

Plantas de situaçăo antes e depois da avenida. e era dividido em dois corpos, o da Escola Normal e o do Jardim da Infância (anos mais tarde demolido para a passagem de uma avenida). O projeto que foi concebido originalmente por Antonio Francisco de Paula Souza e depois desenvolvido pelo escritório do arquiteto Ramos de Azevedo, possuía planta em forma de "U”, simétrica, e continha basicamente salas de aula (em duas alas, a masculina e a feminina) organizadas em dois pavimentos ${ }^{8}$. Podemos reconhecer então no projeto o WOLFF (1992) destaca como o caráter monumental assumido pela arquitetura escolar pública de então:

"A arquitetura escolar pública nasceu imbuída do papel de propagar a ação de governos pela educação democrática. Como prédio público, devia divulgar a imagem de estabilidade e nobreza das administrações [...] Um dos atributos que resultam desta

busca é a monumentalidade, consequência de serem as escolas públicas, edifícios muito evidentes, facilmente percebidos e identificados como espaços da esfera governamental".

\section{ARTIGAS (1970) destaca como os modelos arquitetônicos adotados para as escolas públicas republicanas datadas} até 1911 refletiam uma certa ideologia conservadora de educação:

"As estruturas pouco tinham que ver com a forma com que se revestiam. Constituíam uma solução tectônica, pura em sua rudeza, destinada a programas humildes que retratavam os conceitos dominantes sobre ensino. Estruturas para aceitar qualquer forma que o enciclopedismo pedisse como manifestação artística. Aparências que se justificavam por si mesmas, nem impostas

pela estrutura tectônica nem procura de uma forma para o universo brasileiro. Quanto ao programa, tudo era ensino[...] A escola desconhecia qualquer ampliação de seu significado social além de ensinar primeiras letras e taboada. Só muito mais tarde esses programas foram enriquecidos" ${ }^{10}$ Talvez residam na observação feita acima os pressupostos que irão, anos depois, nortear a produção de edifícios escolares de sua autoria: a importância da escola como edifício simbólico, representativo da vida social urbana, como equipamento público da cidade industrial nascente, em evidente oposição à vida rural; a relação da construção com o programa vigente, com as conquistas pedagógicas e a importância dada à estrutura tectônica simples, desprovida das formas neoclássicas que a revestiam na época da escola republicana.

8 Em 1940 a Escola modificou-se. Sobre ela acrescentou-se mais um pavimento. Houve um incremento no programa original com auditório, biblioteca e outros. Outra alteração que acabou por descaracterizar completamente a construção original foi a demolição do bloco do Jardim da Infância, com substancial diminuição da área da escola e o conseqüente "divórcio" com a praça.

9 WOLFF, Silvia Ferreira Santos. 1992. Espaço e Educacão - Os primeiros passos das escolas públicas paulistas. São Paulo, Dissertação de Mestrado Faculdade de Arquitetura e Urbanismo da Universidade de São Paulo.p. 48

10 ARTIGAS, João Batista Vilanova. Sobre escolas..., In Acrópole nº 377. São Paulo, 1970, p. 11. 
Com o advento do Estado Novo criou-se o Ministério da Educação e Saúde Públicas (MESP), que para FAUSTO (2006), representou o marco de uma mudança nos rumos da educação do país:

"A partir de 1930, as medidas tendentes a criar um sistema educativo e promover a educação tomaram outro sentido, partindo principalmente do centro para a periferia. Em resumo, a educação entrou no compasso da visão geral centralizadora. Um marco

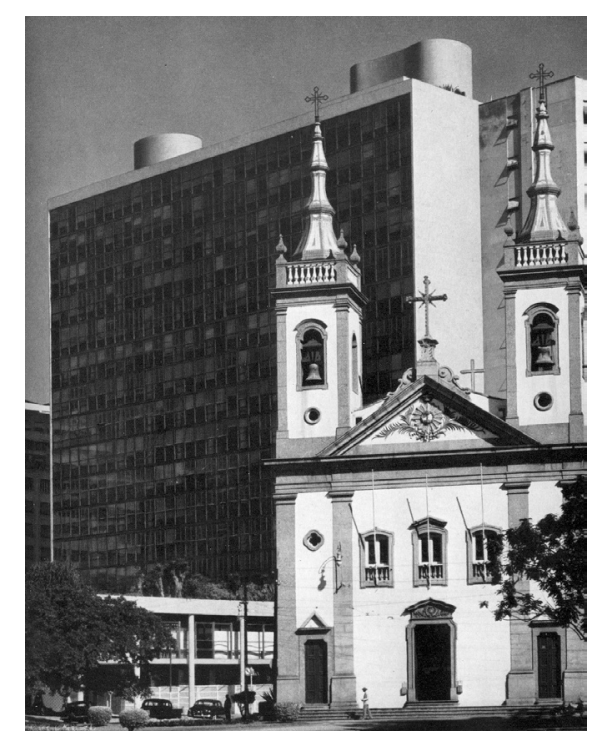

MESP. Lúcio Costa e equipe, 1936 inicial desse propósito foi a criação do Ministério de Educação e Saúde, em novembro de 1930”."1

Em 1934, Gustavo Capanema passou a ocupar o cargo de Ministro da Educação e Saúde, em que permaneceu até 1945. Responsável direto pela iniciativa de promover o concurso público nacional para a construção do edifício sede do Ministério (1935), recusou o projeto ganhador, edifício de feições clássicas de autoria do arquiteto Archimedes Memória, e abriu campo na esfera pública para o desenvolvimento da arquitetura moderna no Brasil ao eleger um grupo de jovens arquitetos, liderados por Lúcio Costa, para projetar a nova sede.O MESP, projetado em 1936 por essa equipe com o auxílio fundamental do mestre Le Corbusier representou um marco na produção arquitetônica brasileira.

"O edifício correspondia, de fato, às esperanças e intenções do ministro que mandara construí-lo. Admirado universalmente, publicado em todas as grandes revistas de arquitetura, tornou-se um símbolo nacional habilmente explorado pelo governo brasileiro na propaganda interna e externa. Portanto, foi decisiva a influência psicológica do Ministério da Educação e Saúde e nenhuma outra realização contemporânea exerceu papel de igual importância. Contudo, não se tratava de uma obra isolada, pois outras de alta qualidade, concebidas dentro do mesmo espírito eram concomitantemente construídas, formando um conjunto que testemunhava a profunda vitalidade da nova arquitetura no país”. ${ }^{2}$

Em 1933, intelectuais liderados pelo educador Fernando de Azevedo ${ }^{13}$ lançaram o Manifesto da Escola Nova, que reclamava para o país uma reforma abrangente do sistema educacional. Preconizava a educação pública, laica, universal, gratuita e unificada como direito do cidadão e desejava romper com a estratificação que dividia as escolas de ensino primário e profissionalizante, voltadas aos pobres, e as de ensino secundário e superior, aos ricos:

11 FAUSTO, Boris. História do Brasil. São Paulo, EDUSP, 2006. P. 337.

BRUAN, Yves. Arquitetura Contemporânea no Brasil. São Paulo, Perspectiva, 1981. P. 93.

Fernando de Azevedo (1894-1874) foi o redator do manifesto (originalmente publicado como Manifesto dos Pioneiros da Educação). Trabalhou como diretor da Instrução Pública de São Paulo, fez parte do grupo fundador da Universidade de São Paulo, além de catedrático e diretor da Faculdade de Filosofia, Ciências e Letras. É autor do livro A Cultura Brasileira. 
“Os educadores liberais sustentavam o papel primordial do ensino público e gratuito, sem distinção de sexo. Propunham o corte de subvenção do Estado às escolas religiosas e a restrição do ensino religioso às entidades privadas mantidas pelas diferentes confissões [...] O manifesto constatava a inexistência no Brasil de uma cultura própria ou mesmo de uma cultura geral. Marcava a distância entre os métodos atrasados de educação no país e as transformações profundas realizadas no aparelho educacional de outros países latino-americanos, como o México, o Uruguai, a Argentina e o Chile”. ${ }^{4}$

Pouco tempo depois do Manifesto (e contando com a participação de seus idealizadores) foram criadas, no âmbito do ensino superior, as Universidades de São Paulo, em 1934, e a do Distrito Federal, em 1935, no Rio de Janeiro. O Secretário da Educação do Distrito Federal era o educador baiano Anísio Teixeira, responsável direto pela idealização e implementação da Universidade do Distrito Federal e membro integrante do grupo responsável pela publicação do referido manifesto.

De 1932 a 1935, Anísio Teixeira assumiu a função de Secretário Geral de Educação e Cultura da Prefeitura Municipal do Rio de Janeiro, então capital do Distrito Federal. Nesse período foi responsável pela construção de vinte e oito escolas para o ensino primário (das mais de oitenta previstas originalmente), seguindo os preceitos de suas novas propostas pedagógicas e contando com projetos “modernos" realizados pelo arquiteto Enéas Silva.

Vale ressaltar aqui, a propósito dessa menção, alguns pressupostos programáticos das primeiras propostas pedagógicas de Anísio Teixeira, inicialmente denominados de “Sistema Platoon”, que representava a transposição aos trópicos dos ensinamentos adquiridos durante sua passagem pelos EUA como discípulo de John Dewey na Teacher's College da Columbia University, em Nova York. Atividades esportivas, de recreação, artes manuais, música, educação cívica, entre outras, enriqueciam o programa escolar e conseqüentemente a construção deveria adaptar-se a essa nova proposta educativa.

“... o que caracteriza a escola Platoon fisicamente falando é a simultaneidade de uso das salas de aula feita possível graças à discriminação e separação das matérias em dois grandes grupos ou "Platoons" possibilitando - assim que num determinado momento estejam as crianças em atividades chamadas fundamentais (home-room-subjects) isto é, recebendo instruções do ensino fundamental ou em atividades especiais (special subjects)" ${ }^{15}$ 


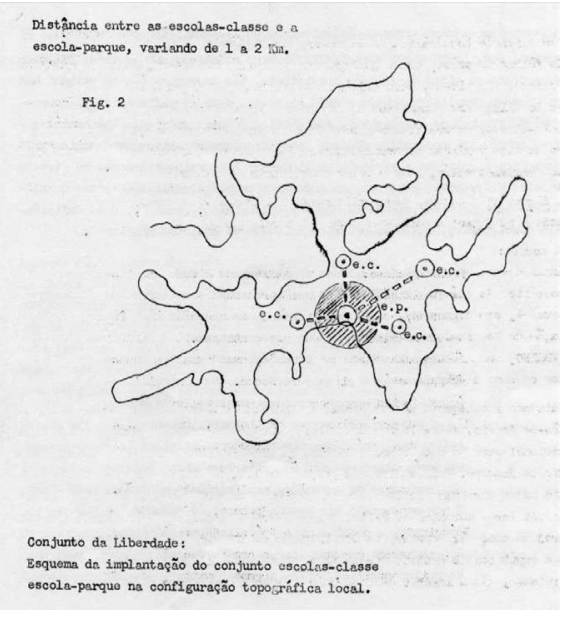

Conjunto Liberdade. Diógenes Rebouças, Salvador, 1954.
Anísio Teixeira, em livro publicado em 1934, propõe que o aprendizado deve aproximar-se das experiências adquiridas e a escola, da vida:

“Com relação às atividades concernentes aos problemas de alimentação, de casa e de vestimenta, a escola, por intermédio de projetos devidamente escolhidos, porá o aluno em contato com os conhecimentos que se encontram na história natural, na agricultura, na geografia, nas artes industriais e na aritmética. Com relação às atividades de organização e regulamentação da vida cooperativa da classe e da escola, - o estudo do direito, da história e da literatura fornecerá objeto para discussões, pelas quais se verá como a humanidade acumulada na literatura, na música, nas artes, nos jogos e nas danças será devidamente aproveitada. E em todas essas atividades, os instrumentos da leitura, da escrita, do desenho, da aritmética e a habilidade manual terão sempre uma grande contribuição" ${ }^{16}$

Anísio Teixeira assumiu, em 1950, a Secretaria de Educação e Saúde do Governo da Bahia, quando teve a oportunidade de implantar sua proposta pedagógica em Salvador. Fruto da experiência adquirida no Rio de Janeiro, o Centro Educacional Carneiro Ribeiro, projeto do arquiteto Diógenes Rebouças (com a participação de Hélio Duarte), foi o único edifício em que conseguiu aplicar na íntegra sua proposta de "escolas-classes" integradas à "escola-parque". A "escola-classe" pode ser definida como a escola tradicionaladaptada à escala do aluno e integrada ao espaço externo através das conquistas arquitetônicas e a "escola parque", como lugar das atividades complementares, como esporte, lazer, artes industriais, dentre outras.

Em 1960 o educador levou seu legado à Brasília, onde, além de implementar o ensino básico e fundamental, criou a Universidade de Brasília. No que tange ao ensino primário, a organização das escolas nas super-quadras foi feita da seguinte forma, conforme o próprio TEIXEIRA (1973):

“- para cada quadra:

um jardim de infância, com 4 salas, para, em dois turnos de funcionamento, atender a 160 crianças (8 turmas de 20 crianças); uma escola-classe, com 8 salas, para, em dois turnos, atender a 480 meninos (16 turmas de 30 alunos);

para cada grupo de 4 quadras:

a) uma escola-parque, destinada a atender em dois turnos, cerca de 2.000 alunos de quatro escolas-classe, em atividades de iniciação ao trabalho (para meninos de 7 a 14 anos) nas pequenas oficinas de artes industriais (tecelagem, tapeçaria, cerâmica, 


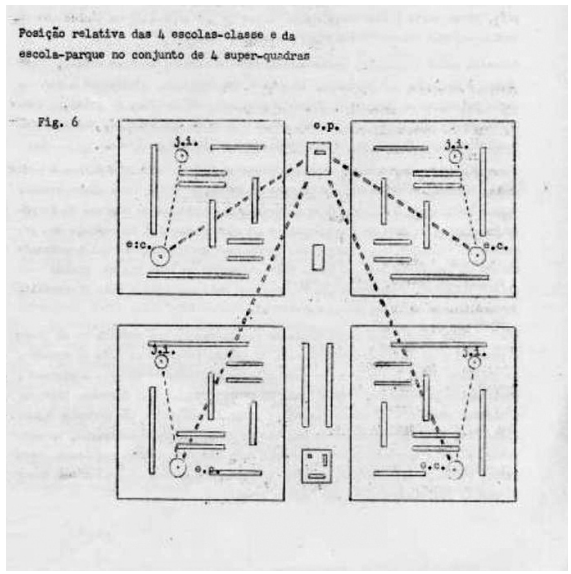

Esquema de implantação das escolas-classe / Escola Parque em cartonagem, costura, bordado e trabalhos em couro, lã, madeira, metal, etc.) além da participação dos alunos em atividades artísticas, sociais, e de recreação (música, dança, teatro, pintura, exposições, grêmios, educação física)." ${ }^{17}$

Do ponto de vista daquilo que se pretende tratar neste trabalho, interessa encontrar os ecos dos avanços pedagógicos propostos por Anísio Teixeira na arquitetura escolar brasileira produzida a partir de então. Assim sendo, escolhemos alguns exemplos que consideramos precursores dessa aproximação sugerida. Dois arquitetos e duas obras de cada, projetadas quase concomitantemente. Os arquitetos são Affonso Eduardo Reidy e Oscar Niemeyer. Do primeiro elegemos a Escola Infantil de Pedregulho, no Rio de Janeiro, e a Escola Brasil Paraguai em Assunção (Paraguai); do segundo, a Escola para Meninos de Cataguases e a Escola Júlia Kubitscheck em Diamantina, ambas em Minas Gerais. 


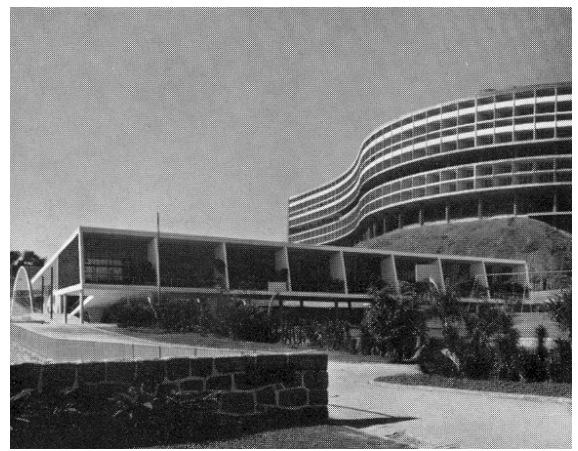

Escola Infantil. Rio de Janeiro. Reidy, 1949

\subsection{Alguns Exemplos}

\subsubsection{Escola Infantil de Pedregulho, Rio de Janeiro, 1946. Affonso Eduardo Reidy.}

Projetado em 1946 para o Departamento de Habitação Popular da Secretaria-Geral de Viação e Obras da Prefeitura do Rio de Janeiro, órgão idealizado pela engenheira Carmen Portinho, a Escola Infantil de Pedregulho foi projetada como parte integrante do Conjunto Residencial de Pedregulho. A obra tem grande importância na carreira profissional de Reidy, que por ela ganhou o 1 Prêmio da Bienal Internacional de São Paulo de 1951, o que Ihe conferiu grande repercussão nacional e internacional.

Carmen Portinho teve influência direta na realização desse e de outros projetos e obras do arquiteto. Em depoimento de 1998, ela assim define o começo do conjunto de Pedregulho:

“A origem da construção do Pedregulho começou em 1945, quando regressei da Inglaterra, onde havia colaborado com arquitetos e engenheiros britânicos na reconstrução de suas cidades no final da Segunda Grande Guerra. Imbuída de grande entusiasmo, propus ao secretário de Obras e Viação da Prefeitura do Distrito Federal a criação do Departamento de Habitação

Popular, uma vez que aqui, como na Inglaterra naqueles anos terríveis, a moradia popular continuava sendo problema de difícil solução. Como ainda hoje em dia. A idéia foi tão bem aceita pelo prefeito que ele acabou me nomeando diretora do novo

Departamento de Habitação Popular.

Logo que assumi, o primeiro projeto seria a construção de conjuntos habitacionais, sob novo conceito de moradia, destinados à população de baixa renda e, principalmente, localizados próximos aos seus locais de trabalho. Com isso, economizariam tempo

e dinheiro gasto com transporte. Enfim, seriam moradias dignas, respeitando o trabalhador, pondo-lhe ao alcance todas as comodidades da vida moderna, integrando-as também às artes”."

O Conjunto localiza-se no bairro industrial de São Cristóvão, um dos mais antigos do Rio de Janeiro, em terreno de cerca de 50 mil metros quadrados, ao lado do antigo Reservatório Imperial. Servia, na proposta original, a 570 famílias, com densidade demográfica de 500 hab./hec. e previa a existência de quatro blocos habitacionais de diferentes tipologias (os blocos A, B1 e B2 e o bloco C, não construído). Além dos edifícios habitacionais, o conjunto conta com equipamentos de apoio à vida doméstica: escola primária; ginásio, piscina e vestiários;

18 PORTINHO, Carmem, 1998 apud BONDUKI, Nabil Georges. Departamento de Habitação Popular. In: BONDUKI, Nabil Georges (org.). Affonso Eduardo Reidy. São Paulo: Instituto Lina Bo e P. M. Bardi; Lisboa: Editorial Blau. 1999. P. 82. 
centro de saúde; lavanderia e mercado; creche e playground. Além desses equipamentos, junto ao bloco C o projeto propunha a instalação de escola maternal, creche e clube (não construídos). REIDY e PORTINHO (s/ data) referiram-se à questão dos equipamentos públicos complementares da seguinte forma:"[...] a função habitar não se resume na vida de dentro da casa. Ela se estende, também, a atividades externas, compreendendo serviços e instalações complementares, que proporcionem aos habitantes as facilidades necessárias à vida de todos os dias".19

\section{E assim definem o projeto da Escola Primária, elemento central da composição:}

"A escola primária é, sem dúvida, um dos mais importantes elementos da comunidade. É um centro de influência atuando na formação do caráter e das personalidades das gerações futuras. Na escola primária a criança aprende a viver e a se comportar em sociedade. A influência da escola ultrapassa a criança e vai penetrar nos lares dos seus pais, levando aos mesmas noções e conhecimentos que muito contribuem para elevar seu nível de educação [...] A transformação quase radical dos métodos de ensino acarretou naturalmente profundas modificações no plano do edifício escolar. A tendência atual é no sentido de estimular o espírito de cooperação, em formar individualidade pelo livre desenvolvimento das aptidões de cada um. A sala de classe é o elemento básico de uma escola moderna. Sai do tipo tradicional para constituir uma unidade individual que permite uma

relação mais íntima entre mestres e alunos, maior flexibilidade na disposição do mobiliário e maior contato com o exterior, utilizando espaços ao ar livre imediatamente ligados às mesmas". ${ }^{20}$

\section{Segue uma descrição bastante pormenorizada da escola:}

"[...] a escola primária do conjunto deveria ter capacidade para freqüência de 200 crianças (de 7 a 11 anos), ou seja, cinco salas de aulas de 40 alunos cada. As condições locais do terreno, bem como o propósito de orientar as salas de classe para o sul lado da sombra -, levou-nos a adotar a forma quadrada para as mesmas. O corredor de circulação, no lado norte, guarnecidos por peças de terracota que o protegem do excesso de iluminação, permite o estabelecimento de ventilação cruzada, através das aberturas situadas na parte alta das paredes das classes, aproveitando a agradável brisa que sopra do lado norte. As salas de classe prolongam-se e amplos terraços ao ar livre, nos quais, durante os dias mais quentes, são realizados os trabalhos escolares.

Além das cinco salas de classe, dispõem de uma biblioteca, sala de estar, administração, vestiário e instalações sanitárias. O

19 REIDY, Affonso Eduardo; PORTINHO, Carmem. Conjunto Residencial Pedregulho. In: BONDUKI, Nabil Georges (org.). Affonso Eduardo Reidy. São Paulo: Instituto Lina Bo e P.M. Bardi; Lisboa: Editora Blau, 1999, p. 83

20 Idem. P. $84-85$. 


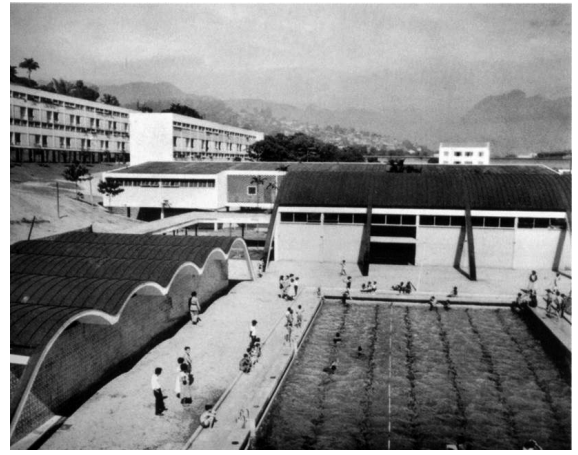

Piscina, vestiário e ginásio.

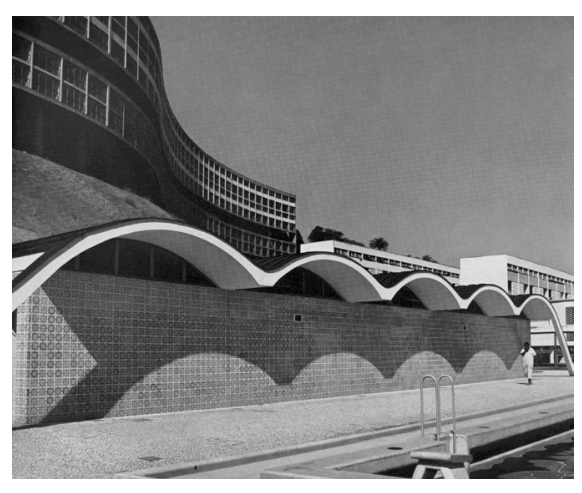

Vestiário.

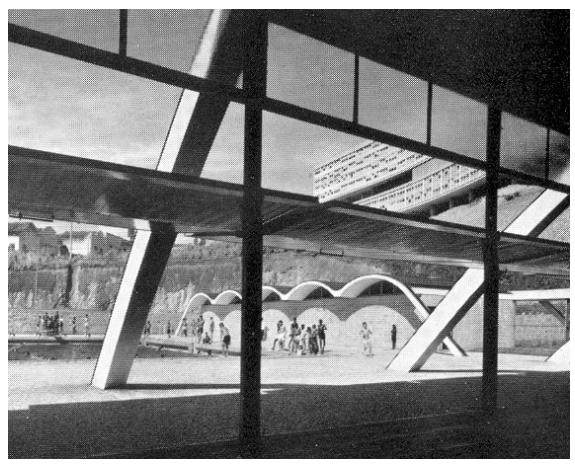

Portas basculantes do ginásio. bloco das aulas, sobre pilotis, proporciona local para recreio coberto, em prolongamento ao playground. Foram localizados sob o mesmo a cantina, onde é servida uma refeição às crianças, uma pequena cozinha e as instalações sanitárias do recreio. $\mathrm{O}$ acesso

às salas de classe é feito por uma larga rampa coberta.

A Escola funciona em dois turnos, podendo, pois, atender não só aos moradores do Conjunto, como também a parte das

crianças excedentes das escolas de bairros vizinhos.

GINÁSIO, PISCINA, VESTIÁRIOS E CAMPOS DE JOGOS AO AR LIVRE: A circunstância de estar este conjunto num bairro muito quente e longe das praias de banho, fez com que fosse construída uma piscina de $12 \mathrm{~m}$ opor $25 \mathrm{~m}$. A Piscina, o ginásio, o vestiário e o campo de jogos ao ar livre constituem um conjunto completo para a prática da cultura física. Uma equipe de instrutores dirige as atividades esportivas e de recreação de crianças e de adultos, em diferentes horários.

O serviço de recreação funciona perfeitamente entrosado com a escola primária, e o ginásio é utilizado, também, para solenidades e festas escolares.

O lado do ginásio que dá para a piscina é guarnecido por largas portas basculantes que, quando abertas, transformam num só ambiente toda a área de esporte. As portas em posição horizontal fazem o papel de marquise, proporcionando uma área de sombra".21

Destacamos ainda a utilização da obra de arte como parte essencial da composição arquitetônica. No pátio de recreação sob pilotis, um painel de mosaico feito por Burle Marx com os desenhos de uma série de brincadeiras infantis. Na sala da diretoria, um afresco também de sua autoria. Para completar a composição, painéis de azulejos de Portinari aplicado sobre a parede oeste do ginásio, elemento de grande destaque na paisagem. Em depoimento de 1999, Carmem Portinho se refere às contribuições desses artistas na obra de Reidy:

“Como em todas as obras de Reidy, não poderiam faltar as colaborações de grandes artistas de arte brasileira, como Portinari que, a nosso pedido, fez o desenho de uma criança pulando carniça para o painel de azulejos, instalado em 1951. Fato curioso

é que, na época, Portinari estava em Paris, tendo o contato sido feito por mim através de carta. Depois de receber as plantas

do projeto, ele enviou-me os estudos e maquete com indicação de cores, dando inclusive o modelo de azulejo que deveria ser utilizado, na medida de 15 x $15 \mathrm{~cm}$ [...]O painel, intitulado Crianças Pulando Carniça, com fundo de áreas irregulares em vários tons de azul, ocupa a parede externa principal do ginásio, ao lado da entrada. Outros artistas que colaboraram com Pedregulho foram Burle Marx, que criou um painel interno, além dos jardins circundantes, e Anísio Medeiros”.22

21 Idem. p.86 22 PORTINHO, Carmem. In: Bonduki, Nabil Georges (org.). Affonso Eduardo Reidy. São Paulo: Instituto Lina Bo e P.M. Bardi; Lisboa: Editora Blau, 


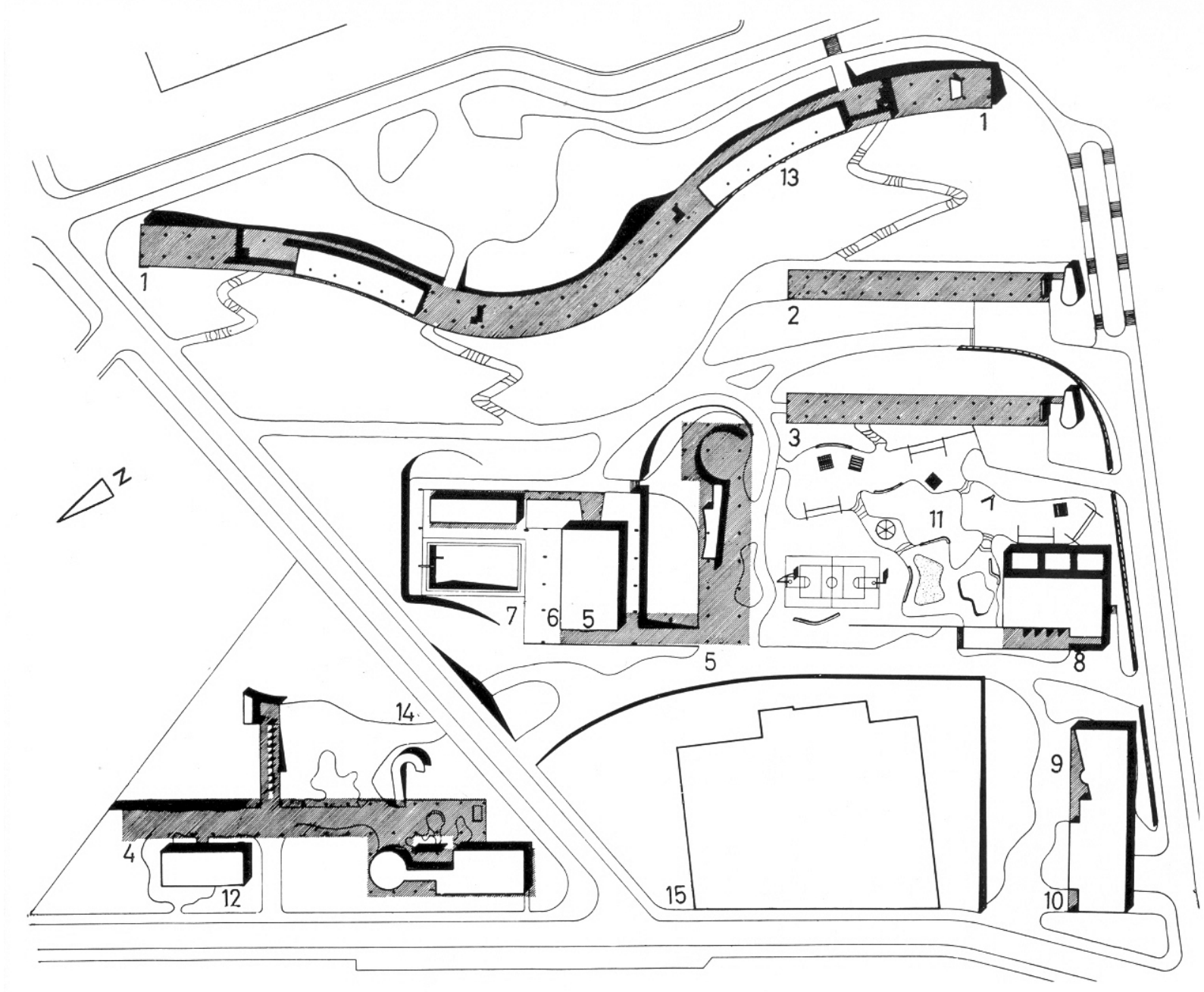




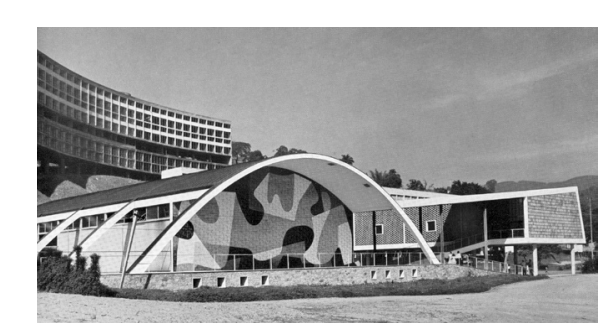

Painel do Portinari.

De baixo para cima, térreo, primeiro pavimento, corte e elevaçăo
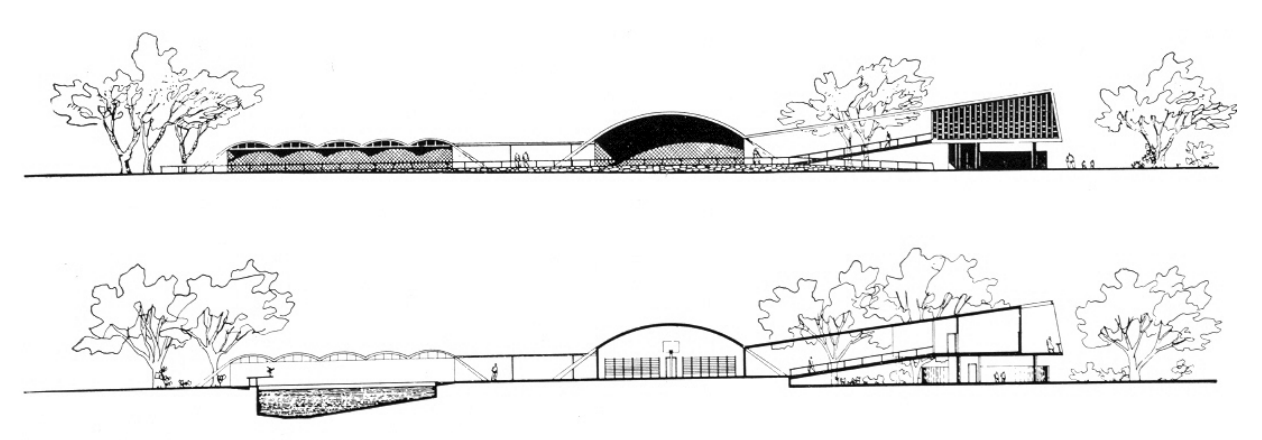

View and longitudinal section, scale 1:1,000

Ansicht und Längsschnitt
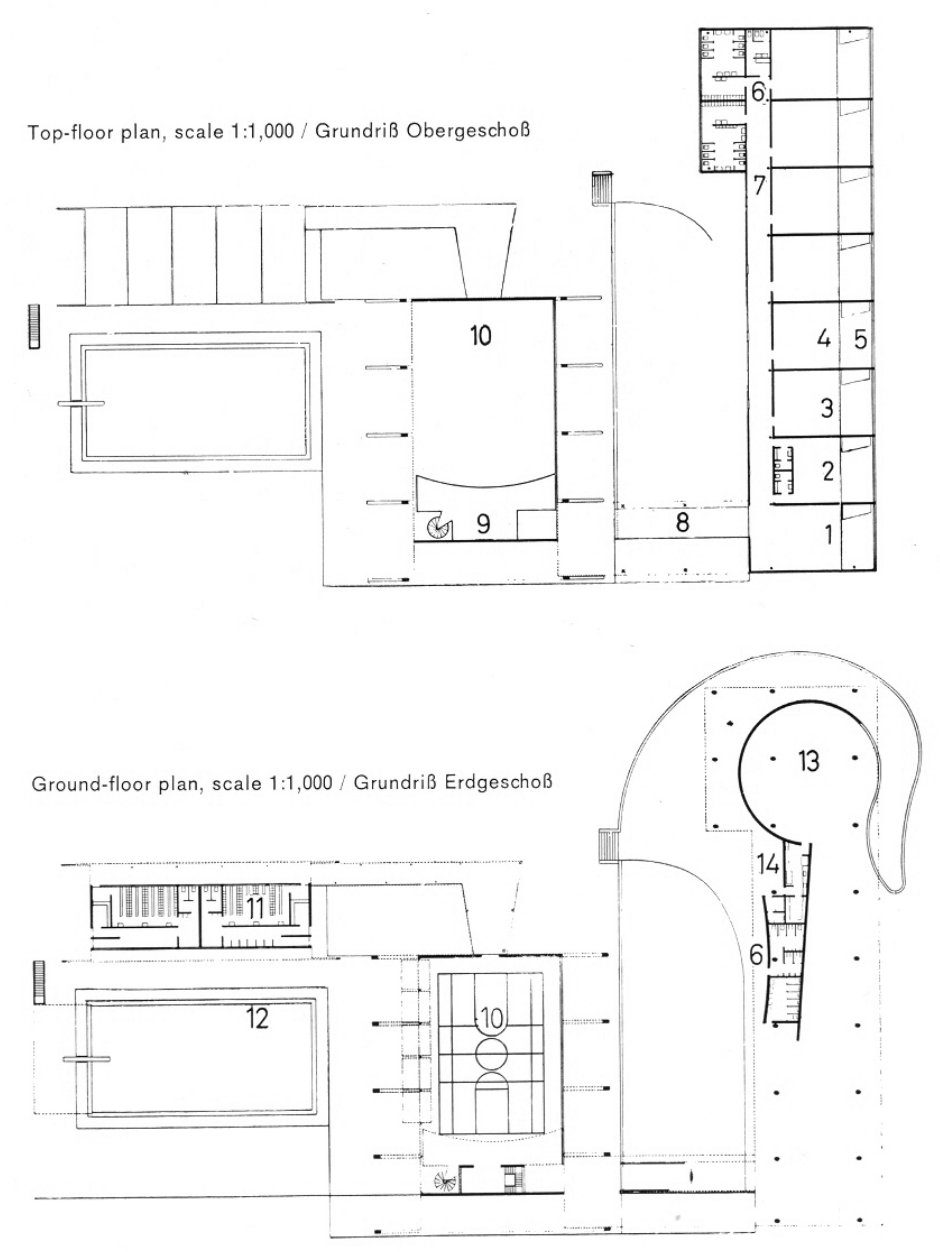


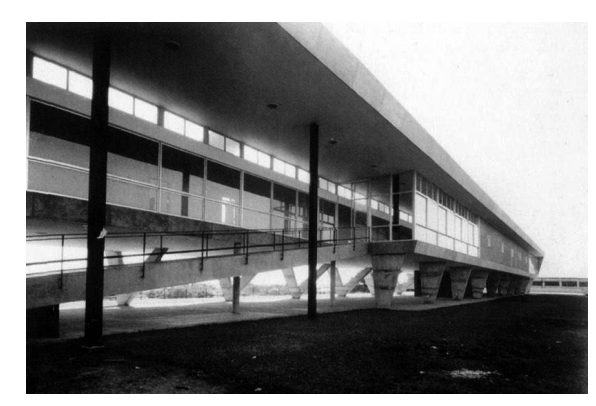

Escola Brasil Paraguai. Rampa de acesso ao pavimento das salas de aula.

\section{Escola Brasil-Paraguai, Assunção, Paraguai, 1952. Affonso Eduardo Reidy}

Um ano antes da realização do projeto para o Museu de Arte Moderna do Rio de Janeiro, Reidy projetou uma escola para Assunção. A obra foi uma doação do governo brasileiro ao paraguaio, feita por meio do Ministério das Relações Exteriores.

Da escola, que está localizada na parte mais elevada do terreno reservado à construção da Cidade Universitária em Yta-Pyta-Punta, divisa-se o rio Paraguai e o Chaco. O projeto previa a existência de três blocos (salas de aula, auditório e ginásio), mas apenas o bloco das salas de aula foi executado, o que muito contribuiu para a descaracterização da obra. Apesar disso, a escola teve grande importância para o desenvolvimento da arquitetura brasileira, especialmente para a arquitetura da edificação escolar em São Paulo em meados do séc. XX.

A unidade tripartida (presente também na escola infantil de Pedregulho) propõe uma relação franca entre a escola e a cidade, sem contudo negligenciar as necessidades próprias das atividades desenvolvidas em sala de aula:

"O bloco das aulas foi disposto no sentido da maior dimensão do terreno, permitindo manter a orientação uniforme e conveniente para todas as aulas, além de proporcionar a melhor vista para o exterior. Em face das condições climáticas locais, a direção norte é a mais indicada para localizar as salas de aula. Foi, entretanto, previsto um quebra sol, constituído por placas longitudinais paralelas, formando uma espécie de marquise, que evitará incidência direta de raios solares, sem prejuízo da iluminação, da ventilação e da visibilidade para o exterior. Além disso, disporão as salas de aula de ventilação transversal, asseguradas por aberturas situadas na face superior das paredes opostas à face das janelas.

Auditório e Ginásio foram dispostos nas proximidades da rua de acesso, de forma a que sua utilização não perturbe o funcionamento normal do Colégio.

As partes edificadas dividem o terreno de maneira a estabelecer uma nítida classificação das funções das áreas livres resultantes."23

A orientação tanto das salas de aula quanto dos outros elementos do programa sugerem, portanto, uma comunicação direta com o espaço social ampliado, como se gradativamente se pudesse passar da cidade às 23 REIDY, Affonso Eduardo. Colégio Brasil - Paraguai. In: BONDUKI, Nabil Georges (org.). Affonso Eduardo Reidy. São Paulo: Instituto Lina Bo e P. M. Bardi; Lisboa: Editorial Balu, 1999, p. 156 


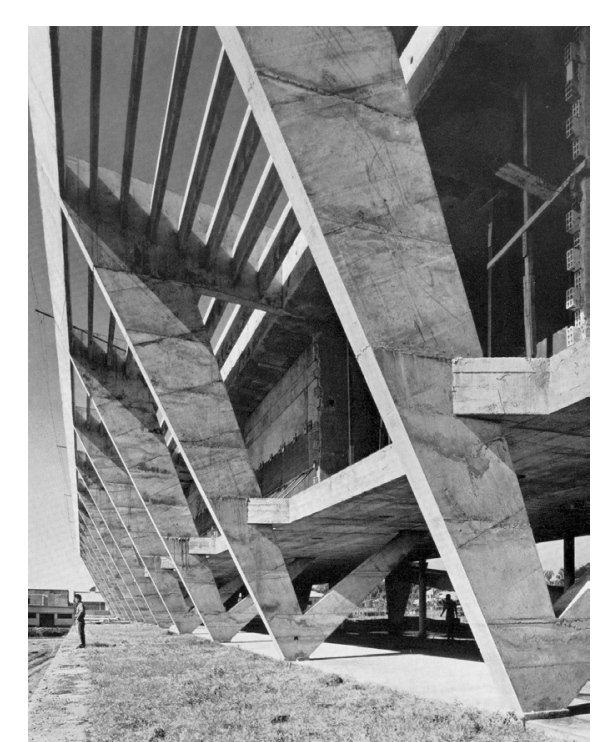

Escola Brasil Paraguai. Brises na fachcada norte. aulas e destas ao Chaco e ao rio. O pavimento térreo é praticamente livre de ocupação, proporcionando vista desimpedida para a paisagem circundante e abrigo aos estudantes durante o recreio.

O interesse estético da obra reside na exposição do sistema construtivo através do uso do concreto armado aparente, da modulação, da independência dos vedos (alvenarias e caixilhos) em relação à estrutura, exercendo assim uma função didática, na medida em que representa, como equipamento urbano, uma referência de constituição de cidade.

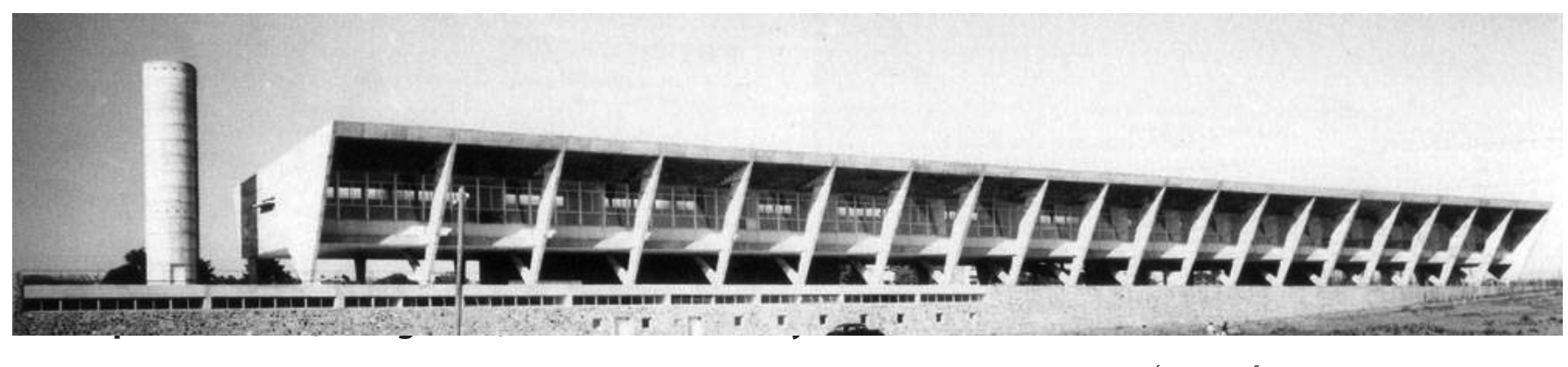




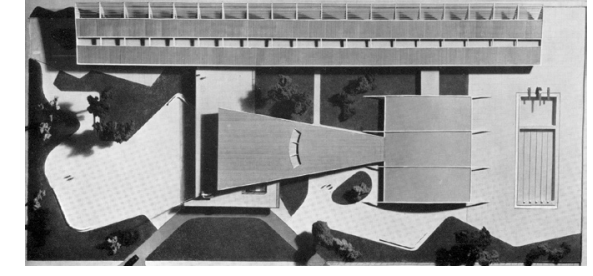

Escola Brasil Paraguai. Maquete.

Escola Brasil Paraguai.

Plantas: térreo, primeiro pavimento e subsolo.
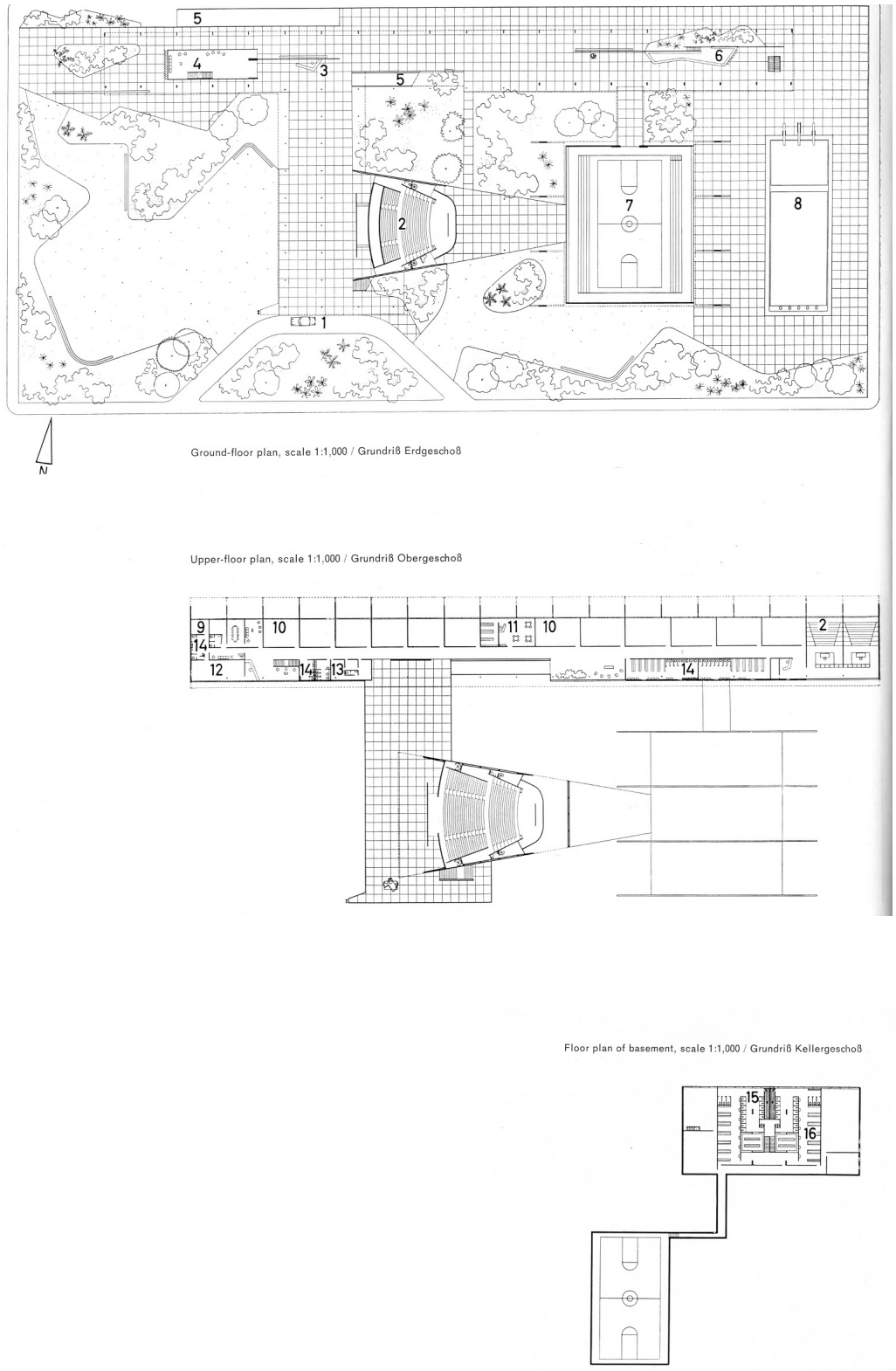


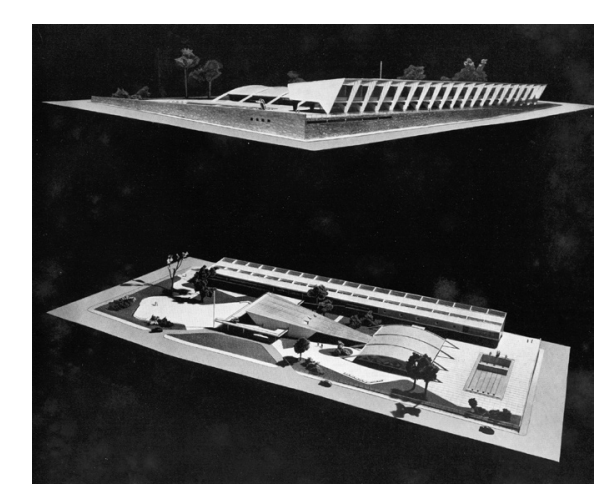

Escola Brasil Paraguai. Maquete.

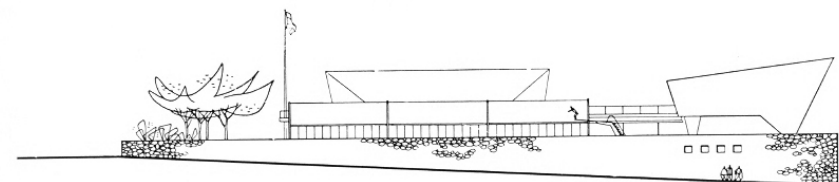

View from the east, scale 1:1,000 / Ostansicht
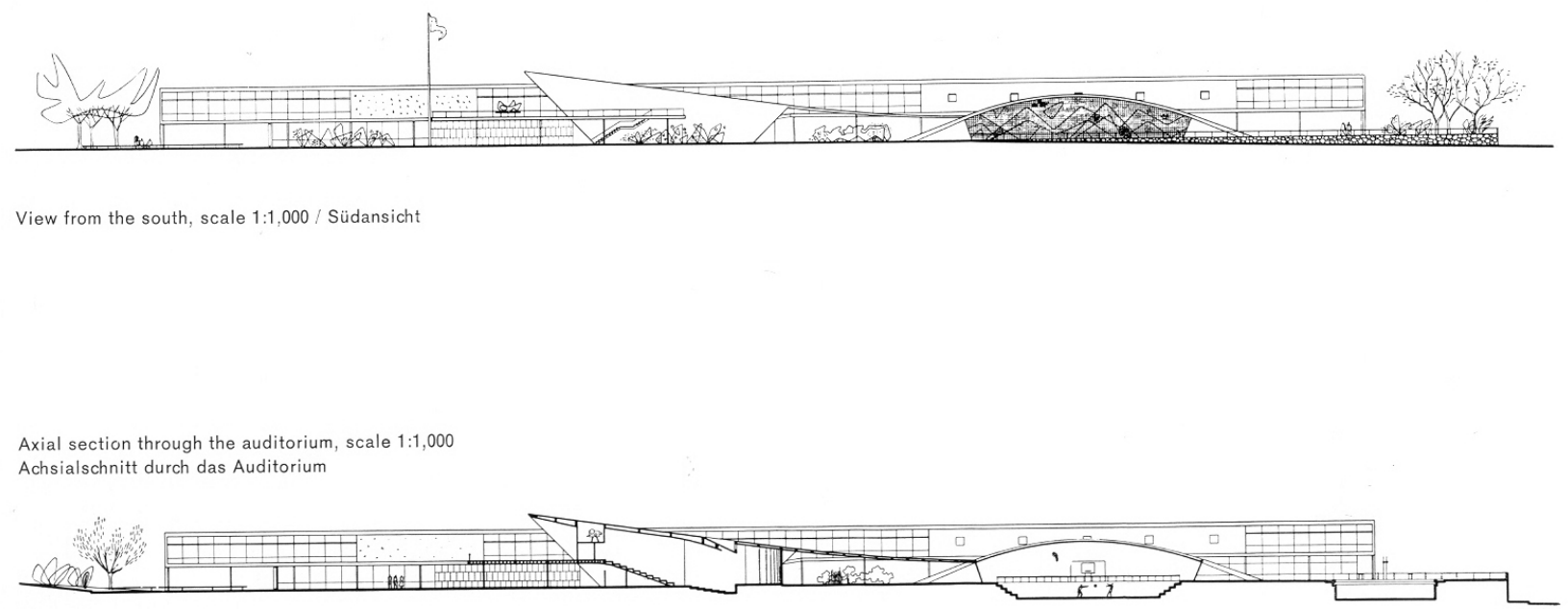


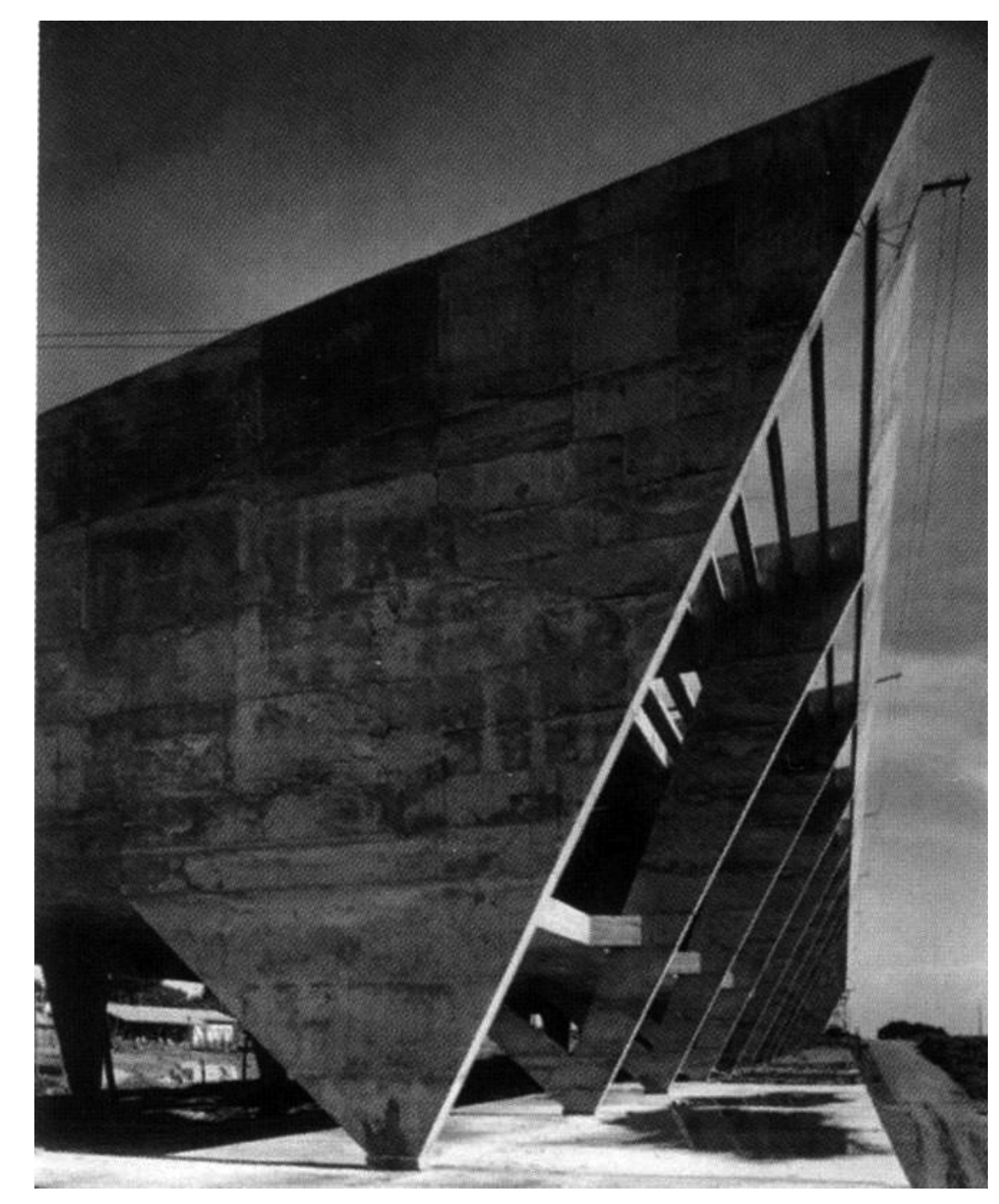




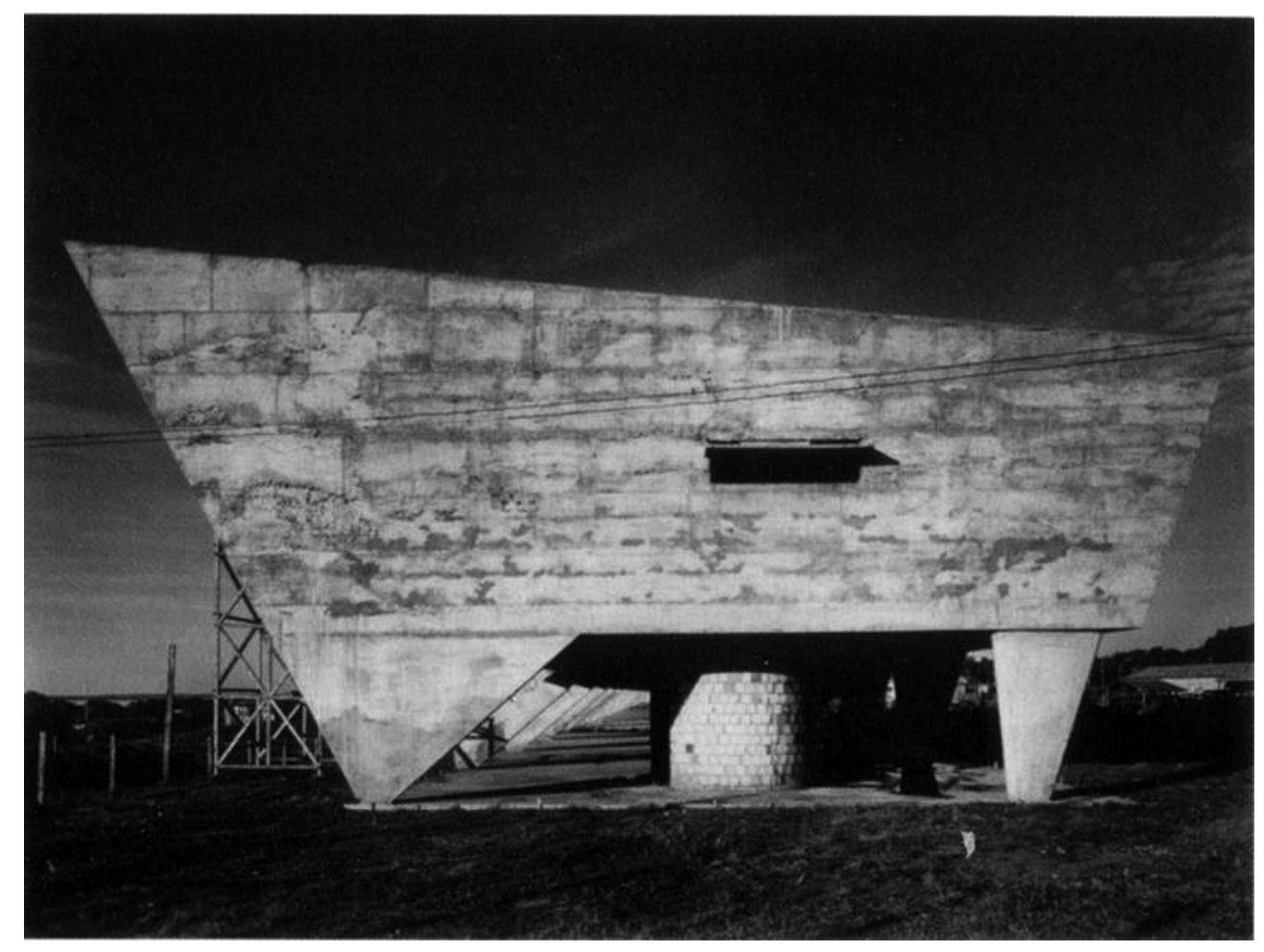




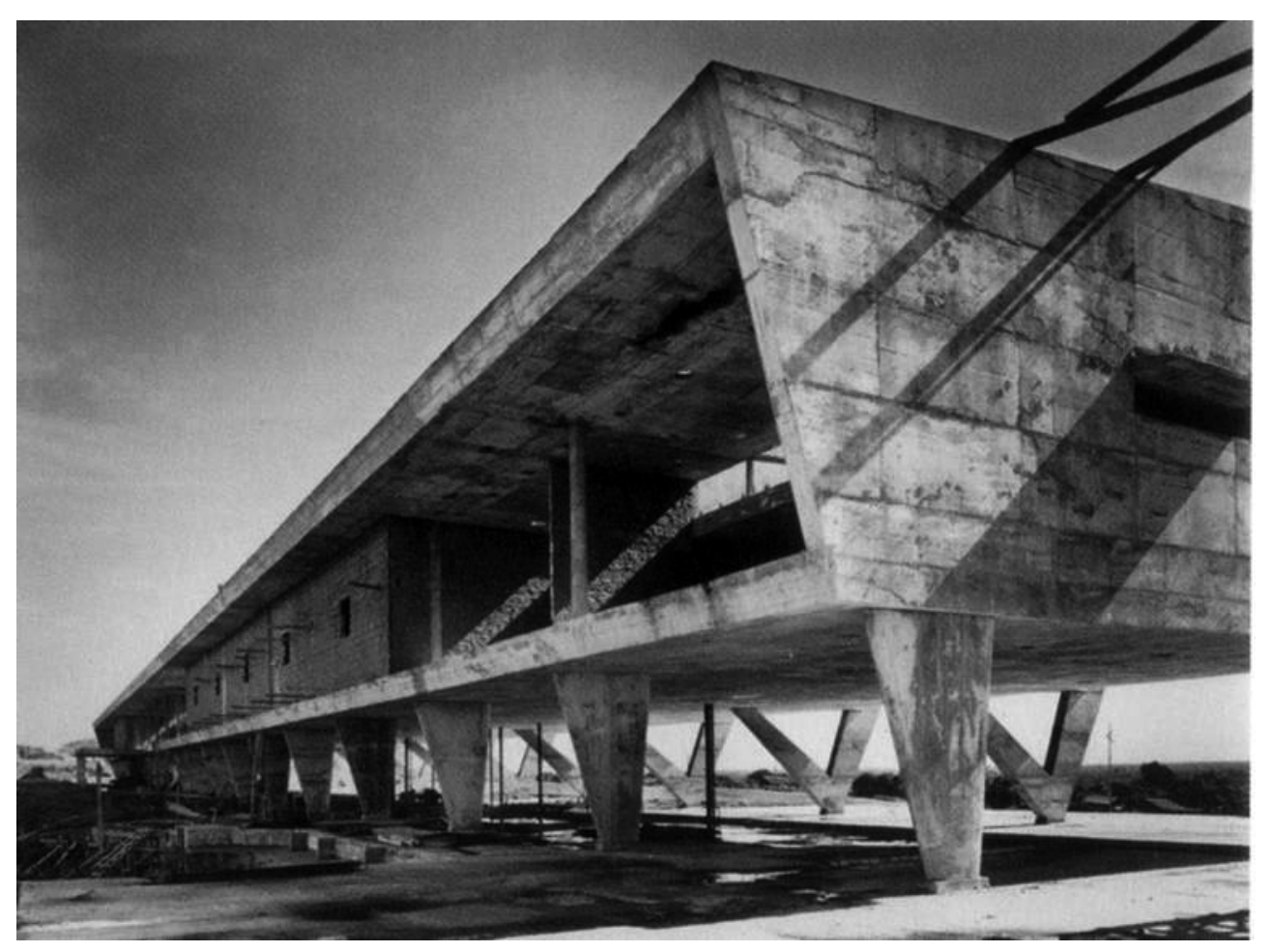




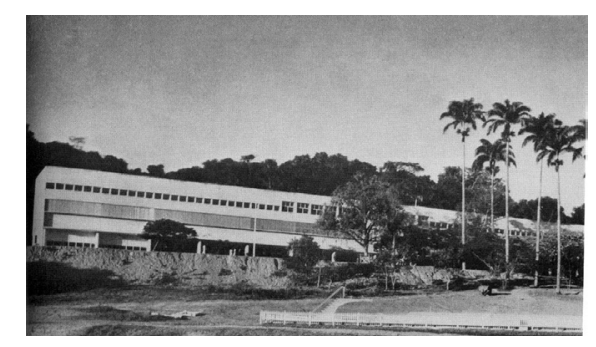

Escola para Meninos. Vista externa.

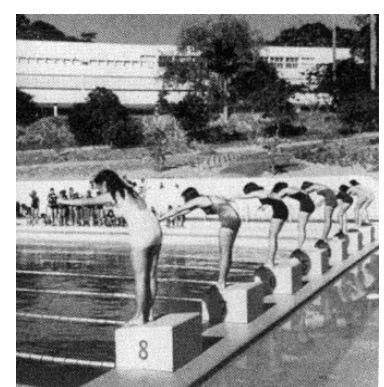

Escola para Meninos. Piscina.

\subsubsection{Escola para Meninos, Cataguases, 1942. Oscar Niemeyer}

Cataguases, cidade da Zona da Mata mineira, notabilizou-se nos anos quarenta como pólo do modernismo arquitetônico brasileiro. Conta com exemplares de Oscar Niemeyer, Francisco Bolonha, MMM Roberto, Aldary Toledo, Edgar do Vale, Gilberto Lemos, Flávio de Aquino, Roberto Burle Marx e dos artistas plásticos Cândido Portinari, José Pedrosa, Anísio Medeiros, Paulo Werneck e Amílcar de Castro. ${ }^{24}$

Niemeyer foi convidado pelo industrial Francisco Inácio Peixoto a projetar sua casa, em 1941. No ano seguinte fez um colégio modelo em chácara da família Peixoto. Projetada para receber trezentos alunos, metade em regime de internato, a escola foi concebida como bloco único ortogonal de três pavimentos com aproximadamente 150 metros de comprimento, em vasta área com cobertura vegetal de grande porte (hoje parque público da cidade). O térreo do edifício contém saguão de acesso, administração, auditório, refeitório, banheiros e pátio coberto de recreação sob pilotis. O primeiro pavimento abriga as salas de aula, todas voltadas para a mesma orientação e protegidas do sol por brises. O segundo pavimento abriga dormitórios para cento e cinqüenta alunos, atualmente convertidos em salas de aula.

O artista plástico Cândido Portinari realizou para o saguão de acesso da escola uma pintura afresco de grande dimensão representando a saga de Tiradentes (anos depois essa pintura foi adquirida pelo governo do Estado de São Paulo e encontra-se hoje no Memorial da América Latina). Completa o conjunto uma piscina pública, provavelmente projetada por Oscar Niemeyer na mesma época.

Chico Buarque de Hollanda, importante figura da cultura brasileira, lá estudou em idos de 1950 e assim descreve essa passagem em texto escrito em 1998 por ocasião da comemoração dos 90 anos de Oscar Niemeyer: "A surpresa desse surto vanguardista é menor, contudo, se nos lembrarmos que a cidade abrigou, através de Humberto Mauro, o principal centro da indústria cinematográfica brasileira e, a partir de 1927, um grupo de intelectuais ali funda a revista literária Verde. Foi justamente um desses intelectuais, Francisco Peixoto, que nos anos quarenta, proprietário de uma indústria de tecidos, inicia o surto modernista em Cataguases, convidando Oscar Niemeyer para projetar sua casa. O desejo de modernidade foi inoculado na então próspera cidade que encontra no novo estilo arquitetônico um instrumento de construção de sua própria identidade longe do provincianismo interiorano". Trecho retirado do Guia Escola Itinerante 2006, roteiro de viagem a Minas Gerais produzido pelo Núcleo de Comunicação da Escola da Cidade em parceria com os professores Álvaro Puntoni, Paula Cardoso, Ruben Otero e Carlos Ferrata. 
"A casa do Oscar era o sonho da família. Havia um terreno para os lados da Iguatemi, havia o anteprojeto, presente do próprio, havia a promessa de que em um belo dia iríamos morar na casa do Oscar. Cresci cheio de impaciência porque meu pai, embora fosse dono do Museu do Ipiranga, nunca juntava dinheiro para construir a casa o Oscar. Mais tarde, num aperto, em vez de vender o museu com os cacarecos dentro, papai vendeu o terreno da Iguatemi. Desse modo a casa do Oscar, antes de existir, foi demolida. Ou ficou intacta, suspensa no ar, como a casa no beco de Manuel Bandeira. Senti-me traído, tornei-me um rebelde, insultei meu pai, ergui o braço contra minha mãe e saí batendo a porta da nossa casa velha e normanda: só volto para casa quando for a casa do Oscar! Pois bem, internaram-me num ginásio em Cataguases, projeto do Oscar. Vivi seis meses naquele casarão do Oscar, achei pouco, decidi-me a ser Oscar eu mesmo. Regressei a São Paulo, estudei geometria descritiva, passei no vestibular e fui o pior aluno da classe. Mas ao professor de topografia, que me reprovou no exame oral, respondi calado: lá em casa tenho um canudo com a casa do Oscar. Depois larguei a arquitetura e virei aprendiz de Tom Jobim. Música do Tom, na minha cabeça, é casa do Oscar “.25 


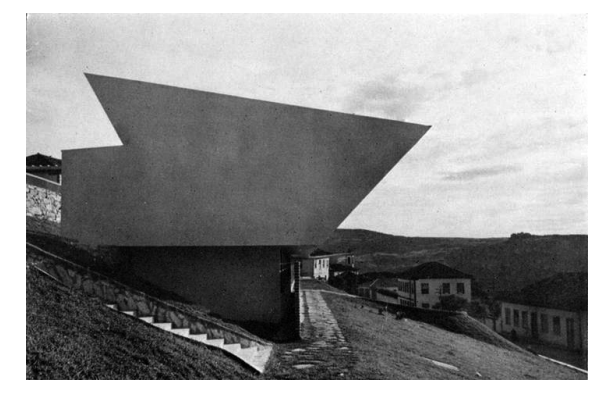

\section{Escola Júlia Kubitscheck, Diamantina, 1951. Oscar Niemeyer.}

A parceria entre Oscar Niemeyer e Juscelino Kubitscheck iniciou-se em Belo Horizonte, na Pampulha (em 1942) e teve seu apogeu na construção de Brasília (em 1960). Na década de 1950, o arquiteto foi chamado a projetar uma escola, um hotel e um clube na cidade natal de Juscelino Kubitscheck, então governador do Estado de Minas Gerais. Tanto a escola como o hotel continuam em perfeito funcionamento e o clube está em ruínas.

A escola, batizada com o nome da mãe de Juscelino (que fora professora em Diamantina), é uma obra de extrema simplicidade e elegância, construída nos moldes das conquistas pedagógicas mencionadas anteriormente, através de uma linguagem moderna numa cidade barroca.

O lugar em que está implantada, bem como os das duas outras obras mencionadas, parecem ter sido escolhido pelo próprio arquiteto, tamanha comunhão entre obra e geografia. Olhando hoje parecem sempre ter estado lá.

A escola contém dois pavimentos, respeitando os gabaritos das construções circunvizinhas. $O$ térreo abriga o saguão de entrada, a administração, o pátio de recreação coberto em pilotis e o refeitório. Uma rampa conecta o térreo ao primeiro pavimento, onde se localizam as salas de aula. Das salas de aula, assim como de todos os principais ambientes da escola, a paisagem descortinada é desconcertante: o Vale do rio Tijuco e as montanhas ao fundo que, quando recebem a luz do sol, parecem refletir ouro. 

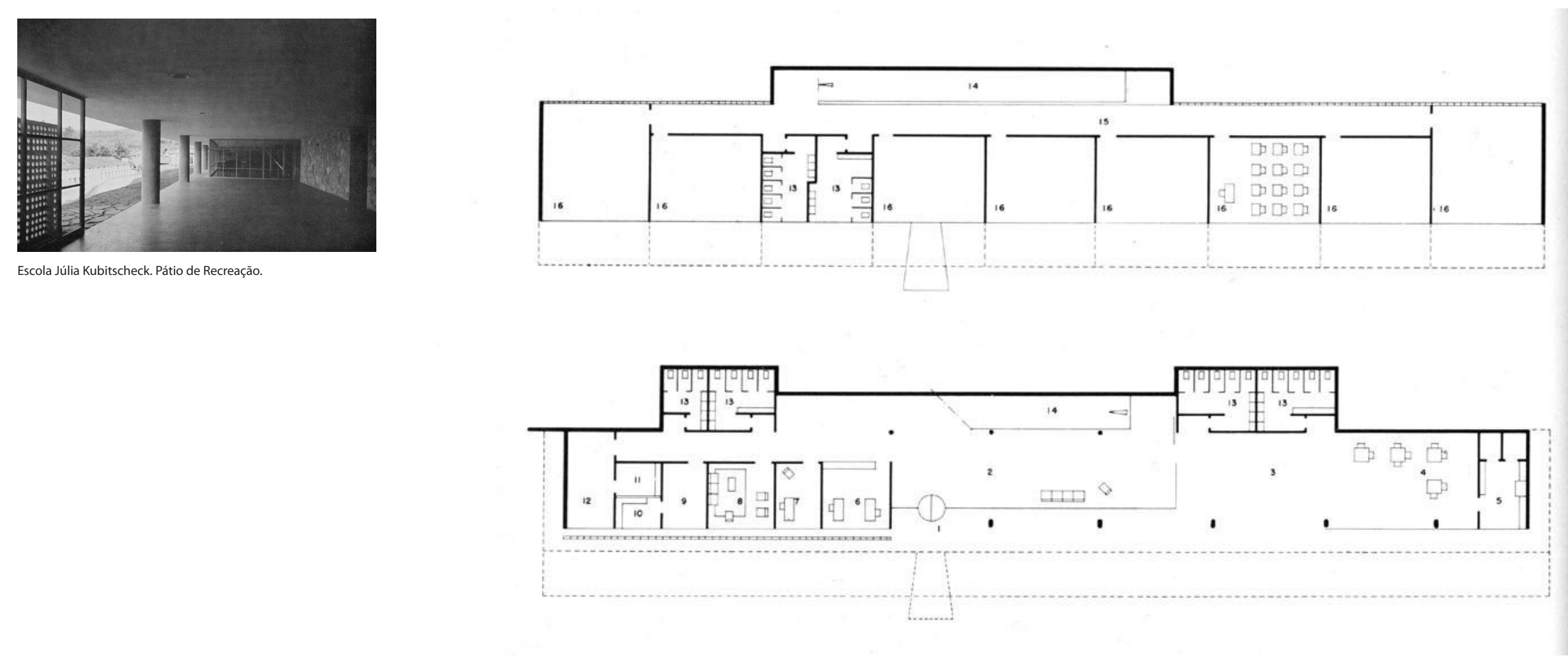

Escola Júlia Kubitscheck.

Plantas: térreo e primeiro pavimento.

Corte Transversa:

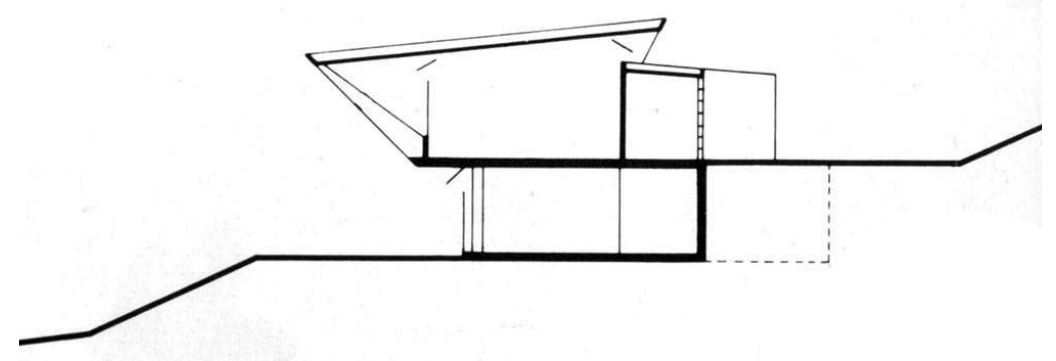



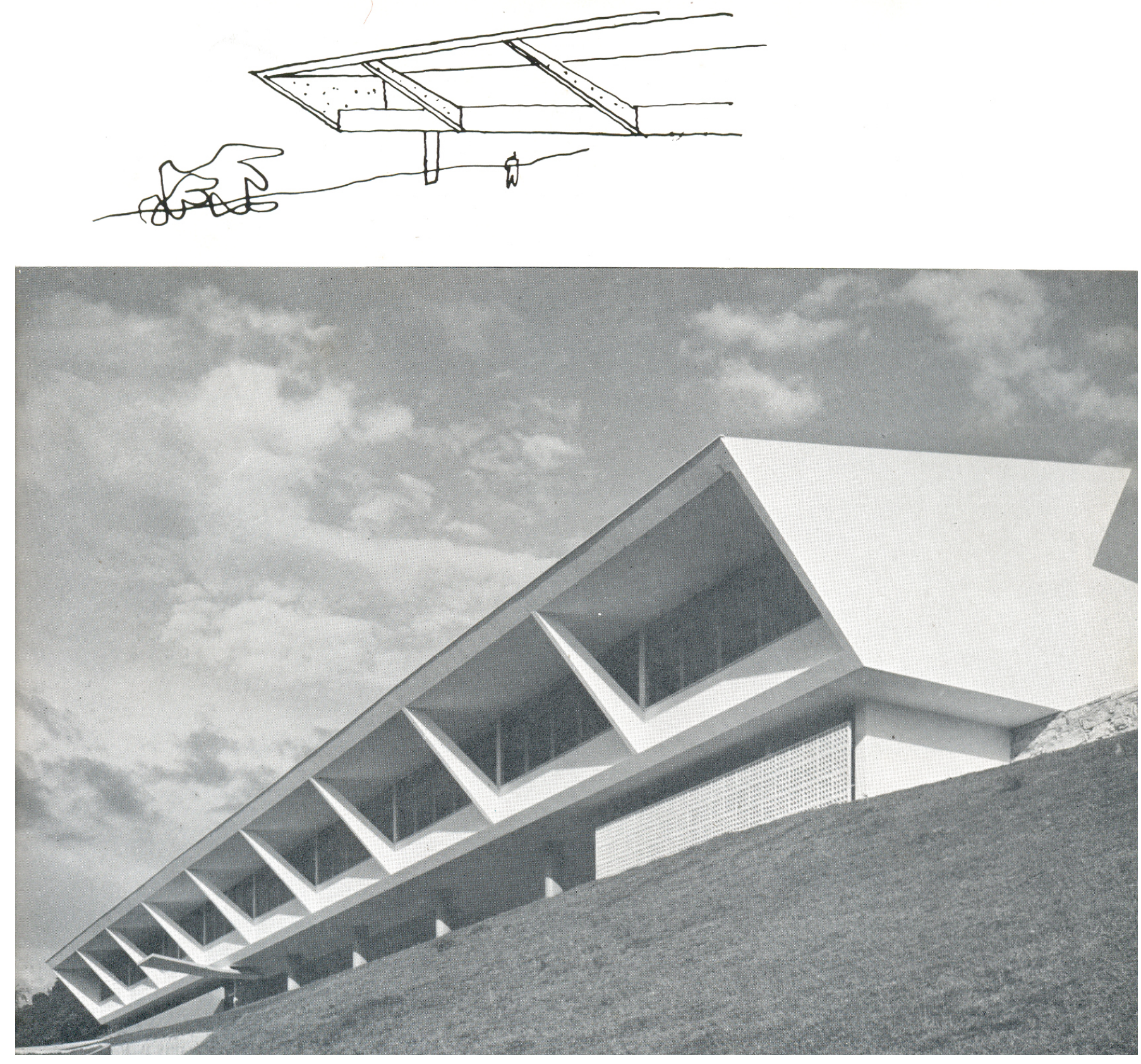
Capítulo 02: O Caso de São Paulo

ESCOLAS PÚBLICAS EM SÃO PAULO (1960-1972)

28 


\subsection{A Produção da Comissão Executiva do $2^{\circ}$ Convênio Escolar (1949-1953)}

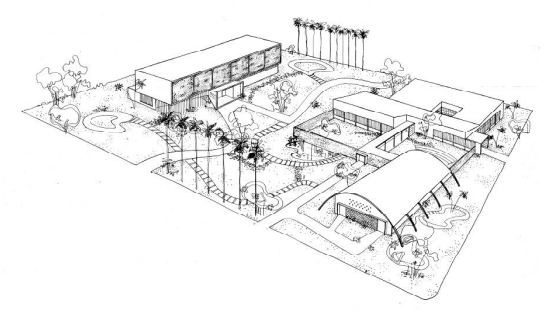

Biblioteca no Tatuapé. Hélio Duarte, 1950

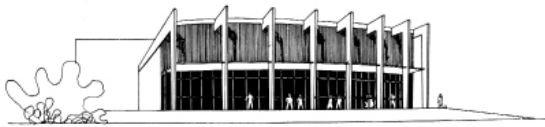

Teatro Popular. Roberto Tibau. 1950.
"Comecemos pelas escolas; se alguma cousa deve ser feita para reformar os homens, a primeira cousa é formálos".1. Em 1949, no estado de São Paulo foi firmado o $2^{\circ}$ Convênio Escolar ${ }^{2}$ : acordo entre estado e município que pretendia zerar, até as comemorações do IV Centenário da cidade, o défict educacional de São Paulo.

Para tanto, foi confiada a uma equipe de profissonais chefiados pelo arquiteto Hélio Queiroz Duarte a tarefa de planejar e executar a rede de escolas e equipamentos correlatos, como parques infantis, bibliotecas e teatros, da cidade de São Paulo. Dessa equipe fizeram parte os arquitetos Eduardo Corona e Roberto Goulart Tibau (formados pela Escola Nacional de Belas Artes do Rio de Janeiro); Ernest Carvalho Mange e Oswaldo Correa Gonçalves (engenheiros/arquitetos formados pela Escola Politécnica da Universidade de São Paulo).

A produção das edificações escolares desse período é marcada pela presença das propostas pedagógicas do educador baiano Anísio Teixeira, já mencionado no primeiro capítulo desse trabalho, que influenciou de maneira decisiva os rumos da edificação escolar em São Paulo. Interessa salientar a relação estreita entre o arquiteto Hélio Duarte e o educador baiano Anísio Teixeira, com quem trabalhou como consultor no projeto para o Centro Educacional Carneiro Ribeiro, em Salvador, e sobre quem anos depois escreveu uma pequena homenagem em forma de livro: Escolas classe- Escola parque ${ }^{3}$.

Nesse sentido, a idéia da escola dinâmica, relacionada à cidade ao redor e aos seus moradores, numa troca ininterrupta, é perseguida permanentemente pelos arquitetos em seus projetos. Arquitetura transpirando os avanços pedagógicos através da escola aberta para a comunidade e dos novos usos atrelados ao edifício escolar.

"Porque não considerar em cada bairro - a escola, o grupo escolar, como fonte de energia educacional, como ponto de reunião social, como sede das sociedades de amigos do bairro, como ponto focal de convergência dos interesses que mais de perto dizem com a vida laboriosa de suas populações?

BARDI, Lina Bo. Primeiro: escolas. Habitat no 4, São Paulo, set-dez, 1951, p. 01.

Houve três convênios firmados entre Estado e Município em São Paulo. O primeiro vigorou de 1943 a 1948, o segundo, de 1949 a 1953 e o terceiro, de 1954 a 1959. Ver a esse respeito: ABREU, Ivanir Reis Neves. Convênio Escolar: Utopia Construída. 2007. Dissertação de Mestrado-Faculdade de Arquitetura e Urbanismo da Universidade de São Paulo (FAUUSP), São Paulo.

3 DUARTE, Hélio Queiroz. Escolas Classe - Escola Parque: uma experiência educacional. São Paulo: Editora da FAUUSP, 1973.

ESCOLASPÚBUCAS EM SÃOPAULO(1960-1972) 


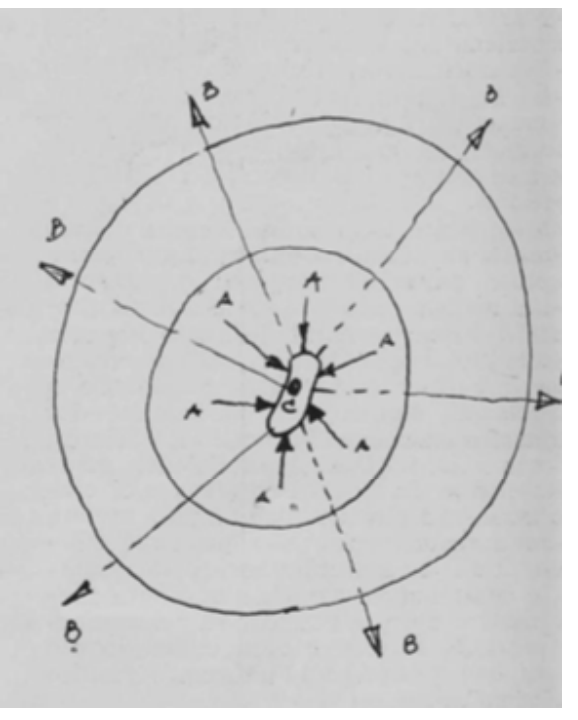

Relação da escola com a comunidade. Hélio Duarte, 1951

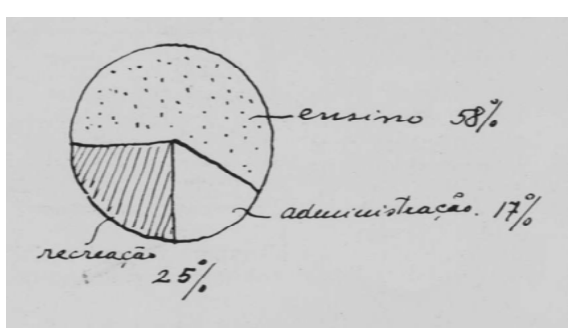

Esquema programático. Hélio Duarte, 1951

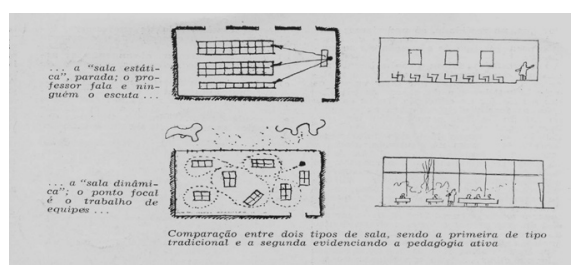

Esquema salas de aula. Hélio Duarte, 1951
Nela, com o aproveitamento integral do prédio, em rodízio de um farto número de horas, poderíamos, a par da educação ministrada, à noite à adultos, recrear e educar um grande número de pessoas.

A escola passaria a ser um verdadeiro cadinho no amálgama da nossa heterogênea população. Reunião de pais, pequenos bailes,

cursos para mães e noivas, pequenas palestras, cinema e teatro educativos, biblioteca, audições de música, teatro de bonecos

e jogos. Tudo aí poderia ser realizado. Forças centrípetas convergiriam para a escola e seriam as concurrentes da formação intelectual, social, e profissional dessas pequenas comunidades, onde depois de processadas passariam a ser as forças centrífugas - difusoras do conhecimento adquirido." ${ }^{4}$

Para isso o edifício escolar deveria mudar, aproximando-se através de seu uso e também de sua construção da vida social ao redor. Assim, a construção escolar despoja-se. Abandona o ar monumental que a envolvia na sua origem republicana e assume a natureza, as árvores e os jardins propostos, ou mesmo o vazio, como parte integrante de sua constituição. As salas de aula também passam a ser pensadas de outra maneira, menos rígidas que de costume, mais próximas da escala da criança e em contato direto com a paisagem externa através do uso de janelas generosas.

A construção foi dividida, via de regra, em três unidades articuladas, respondendo a um esquema desenvolvido pela equipe, que dividia a escola em blocos de funções distintas e complementares: ensino, administração e recreação. Sobre essa última DUARTE (1951) afirma: "A recreação se processa ao ar livre e coberta, atendendo sempre que possível aos imperativos de mobilidade infantil." ${ }^{5}$

Tecnicamente, o projeto deveria responder, com o máximo de urgência, a uma demanda significativa de vagas. Portanto, a construção foi pensada de maneira econômica, contando com a tecnologia mais simples da época, sempre levando em consideração as propostas teóricas formuladas pela equipe e seguindo os preceitos da arquitetura moderna desenvolvida no Rio de Janeiro na época, de "herança corbusiana".como assinala WISNIK (2006):

“ [...] o período do Convênio marca uma iniciativa pioneira de difusão e consolidação da arquitetura moderna em São Paulo através do poder público [...] Hélio Duarte foi o mensageiro e portador, em São Paulo, de importantes legados recentes no Brasil naquele momento: a arquitetura moderna carioca - de herança corbusiana e, àquela altura, já conhecida mundialmente sob a

DUARTE, Hélio Queiroz.O problema escolar e a arquitetura. Habitat nº 4, São Paulo, set-dez, 1951, p. 05-06. DUARTE, Hélio Queiroz. Op. Cit., p. 05. 


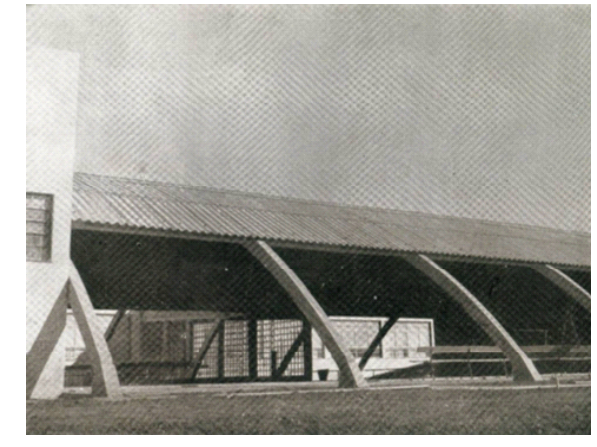

Grupo Escolar José Carlos Dias. Hélio Duarte, 1950 Galpão de recreação alcunha de brazilian style - e o projeto pedagógico de Anísio Teixeira, pioneiro defensor de uma escola pública, laica e gratuita no Brasil, e figura de destaque na fundação do movimento Escola Nova, e na reforma de ensino do Distrito Federal, no início da década de 1930."

Os materiais empregados eram simples, alvenarias de tijolos revestidos e pintados, caixilharia de ferro e vidro, estrutura em concreto armado, paredes de alvenaria (revestidas e pintadas) e coberturas em telhas onduladas de fibrocimento sobre laje. Os volumes articulados eram pensados construtivamente de forma autônoma. Cada um feito de uma maneira e depois articulados, ora com marquises, ora com rampas, passarelas ou escadarias.

Destaque para o galpão coberto de recreação: cobertura feita em estrutura composta de arcos pré-moldados em madeira ou concreto armado sobre os quais apoiavam-se as telhas de fibrocimento, equipado com palco para apresentações teatrais e cinema educativo. Para DUARTE (1951):

“O prédio não deve utilizar o terreno, antes ser com ele homogêneo, adaptar-se-lhe, ser como cousa posta e não imposta. Para a programação de um grupo de 12 salas de aulas estabelecemos as seguintes funções todas concatenadas: - ensino

- recreação

- administração (incluindo o setor assistencial)

Na zona 'ensino' dispomos as salas de aulas, o museu escolar, a biblioteca infantil e a ginástica programada. $\mathrm{Na}$ zona recreação previmos o galpão para recreio coberto, o cinema educativo, com palco para dramatizações.

A 'administração' se compõe de três sub-zonas: a)administração, propriamente dita, com salas para diretoria, secretaria, arquivo, material escolar, sala de professores, biblioteca didática, almoxarifado, e comodo de serventes.

b)assistência escolar, abrangendo as assistências: médico, dentária, social e de nutrição. c)zeladoria com apartamento próprio.”

A forma de organizar essas três zonas articuladas no terreno, atrelada aos meios técnicos utilizados na construção do edifício escolar, confere certa unidade ao conjunto das escolas construídas no período. Ao todo foram executadas cerca de cinquenta e duas escolas na cidade de São Paulo, nos cinco anos que durou o Convênio, o

WISNIK, Guilherme. O programa escolar e a formacão da "escola paulista". In: FERREIRA, Avany de Francisco; MELLO, Mirela Geige (organizadoras). Arquitetura Escolar Paulista: anos 1950 e 1960. Fundação para o Desenvolvimento da Educação (FDE), São Paulo, 2006, p. 59. DUARTE, Hélio Queiroz. O problema escolar e a arquitetura. Habitat nº 4, São Paulo, set-dez, 1951, p. 05. 
que revela o grau de seriedade e coragem com a qual a equipe se lançou no enfrentamento dessa importante questão.

Embora sejam pouco (re)conhecidas no quadro da arquitetura moderna paulistana, as escolas projetadas pelo Convênio são, sem dúvida, as introdutoras da arquitetura moderna no âmbito do poder público paulista. Até então, o estado tinha realizado algumas raríssimas construções que se poderia definir como efetivamente vinculadas ao movimento moderno, como por exemplo os hospitais de Rino Levi, ou a piscina coberta do Parque da Água Branca, projetada por Ícaro de Castro Mello."

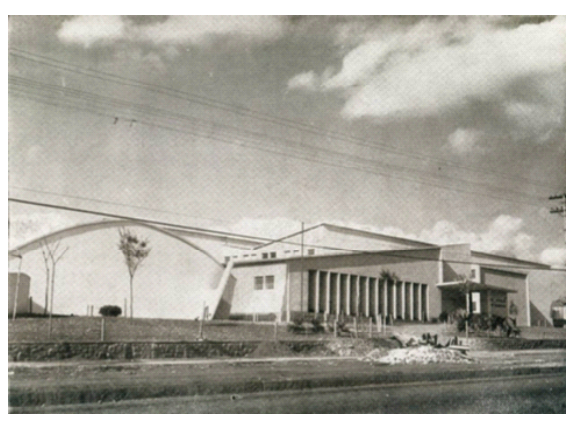

Selecionamos uma obra de cada arquiteto para ilustrar essa importante contribuição à arquitetura nacional, reforçando o caráter coletivo ${ }^{9}$ dessa produção durante a vigência do Convênio Escolar e mesmo depois dele. São elas:

\section{EE Pandiá Calógeras}

Hélio de Queiroz Duarte/ 1949/ Avenida Paes de Barros, 1025, Alto da Mooca. São Paulo, SP

Essa escola concentra os princípios básicos de composição dos edifícios do Convênio Escolar. Unidade tri-partida: bloco administrativo no alinhamento da via de acesso, bloco das salas de aula em dois pavimentos consecutivos e, finalmente, galpão de recreação coberto (com as funções de apoio: cozinha, nutricionista, depósito, banheiros e zeladoria).

A conexão dos blocos é feita por passagens cobertas em forma de "U", ligadas diretamente às galerias de circulação das salas de aula, gerando um interessante pátio interno arborizado. Lugar central de destaque da composição.

A característica mais marcante dessa obra reside no fato dela incorporar, no mesmo terreno, o teatro Arthur de Azevedo, projetado pouco depois pelo arquiteto Roberto Tibau, consolidando naquele trecho do tecido urbano uma espécie de praça de equipamentos sociais.

8 VALENTIM, Fábio Rago. Casas para o Ensino: as Escolas de Vilanova Artigas. 2003. Dissertação de Mestrado-Faculdade de Arquitetura e Urbanismo da Unoversidade de São Paulo (FAUUSP), São Paulo, p. 76.

9 Outros arquitetos participaram do processo. Dentre eles: Aluísio Rocha Leão e Junenal Watage Júnior. Porém restringimos para a leitura proposta algumas obras realizadas apenas pelo núcleo original. 


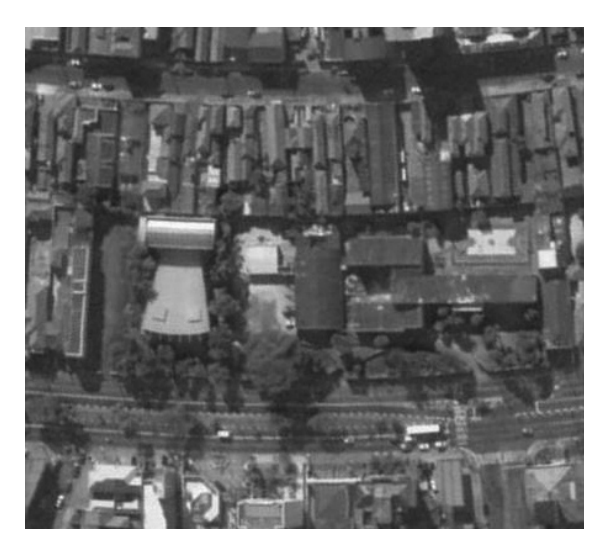

Situação, s/ escala. Pandiá Calógeras. Hélio Duarte, 1951

O teatro Arthur de Azevedo aparece ao lado esquerdo.

EE Pandiá Calógeras. Hélio Duarte, 1951

Plantas s/ escala
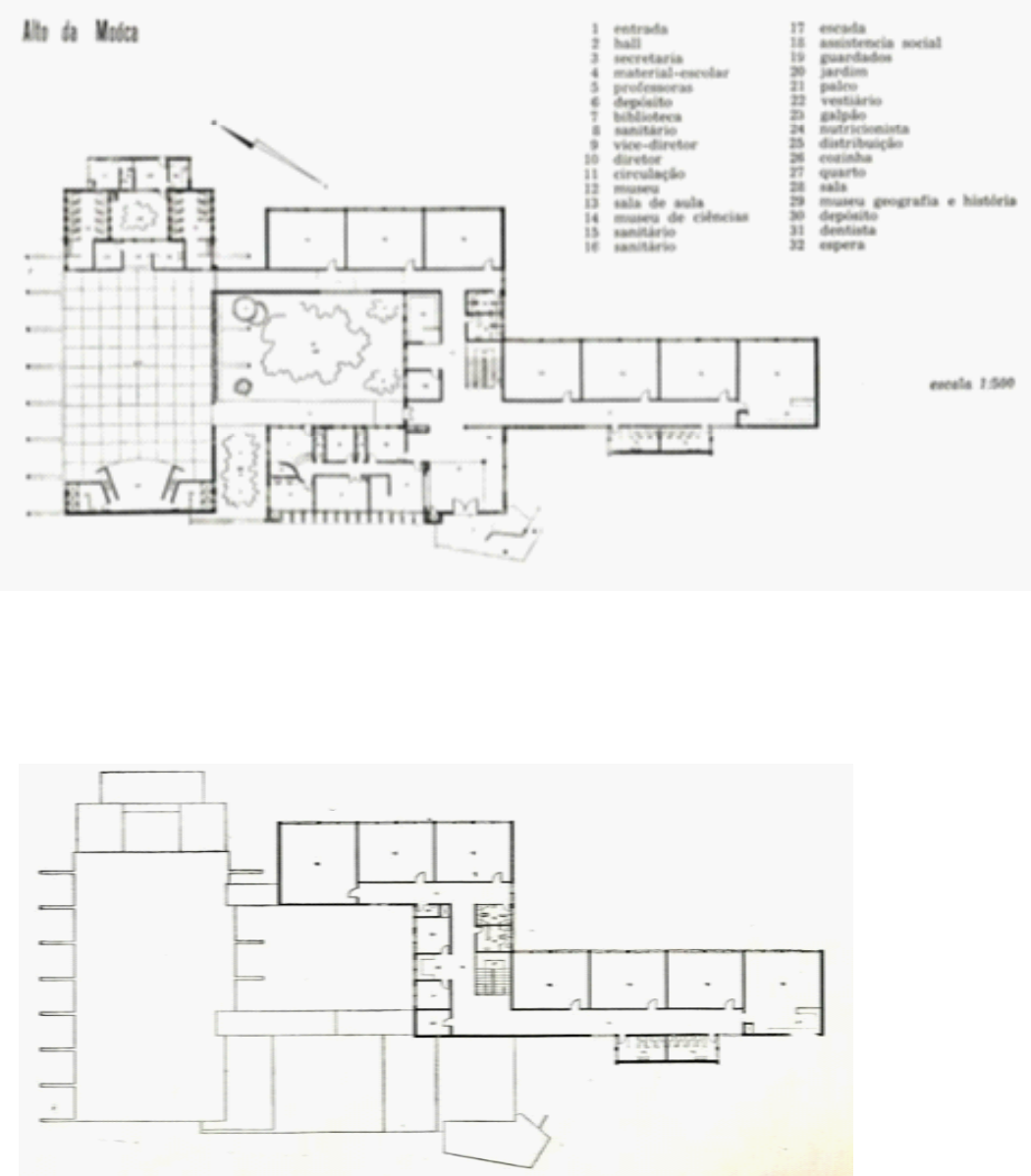

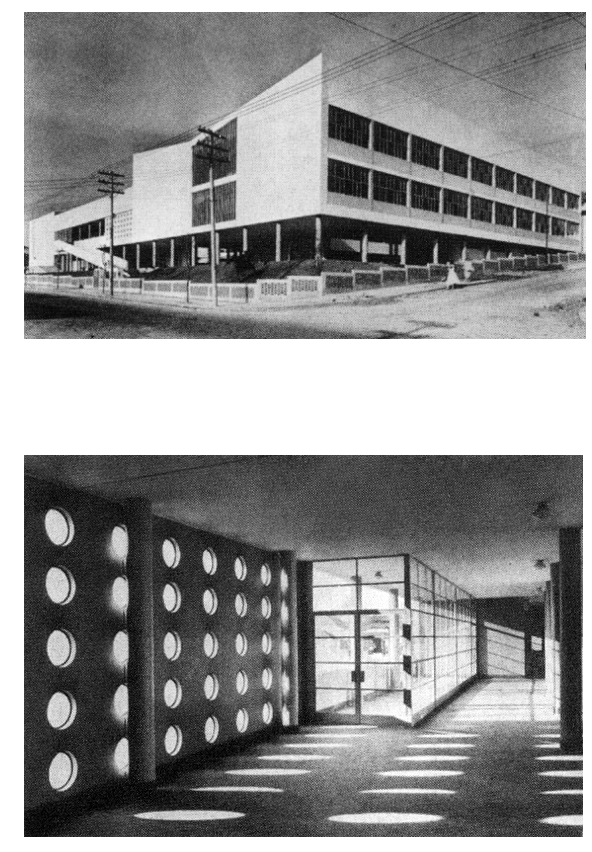

\section{EE Nossa Senhora da Penha}

Eduardo Corona/ 1951/ Rua Padre Benedito de Camargo, 762, Penha. São Paulo, SP

Escola constituída por três blocos justapostos: auditório, administração e salas de aula. Completa o programa do conjunto uma piscina.

O auditório, novidade no programa das escolas, é equipado com palco e pequeno urdimento, vestiários masculino e feminino, platéia e cabine de projeção. Assim, pode ser usado para apresentações diversas: teatro, cinema, apresentações musicais, etc. Além disso, o fato de situar-se numa das extremidades do terreno possibilita que, eventualmente, seja utilizado por um público mais abrangente e funcione inclusive paralelamente às atividades regulares da escola.

Anexado a esse bloco está, em posição intermediária, o volume administrativo de dois pavimentos. No térreo há recepção, museu, diretoria, sala de reunião e imprensa e, no pavimento superior, as funções administrativas complementares e a biblioteca.

O bloco das salas de aula, em três pavimentos, tem forma de "U". Abriga no térreo o pátio de recreação, em pilotis (exceto banheiros e serviços), e nos dois pavimentos superiores, as salas de aula, acrescidas de oficinas e laboratórios, voltados todos à mesma orientação.

O bloco intermediário cumpre o papel de articulação do conjunto. Nele localizam-se escada e rampas. A escada e um lance de rampa conectam o térreo ao primeiro pavimento. Dele para o segundo pavimento chega-se só por um lance de rampa.

Todo o edifício está implantado num platô de nível mais alto do que o da rua de acesso, o que permite aos usuários da escola uma visão desimpedida da paisagem da cidade ao redor. Outra característica interressante desse prédio é o pátio arborizado entre as alas das salas de aula. 

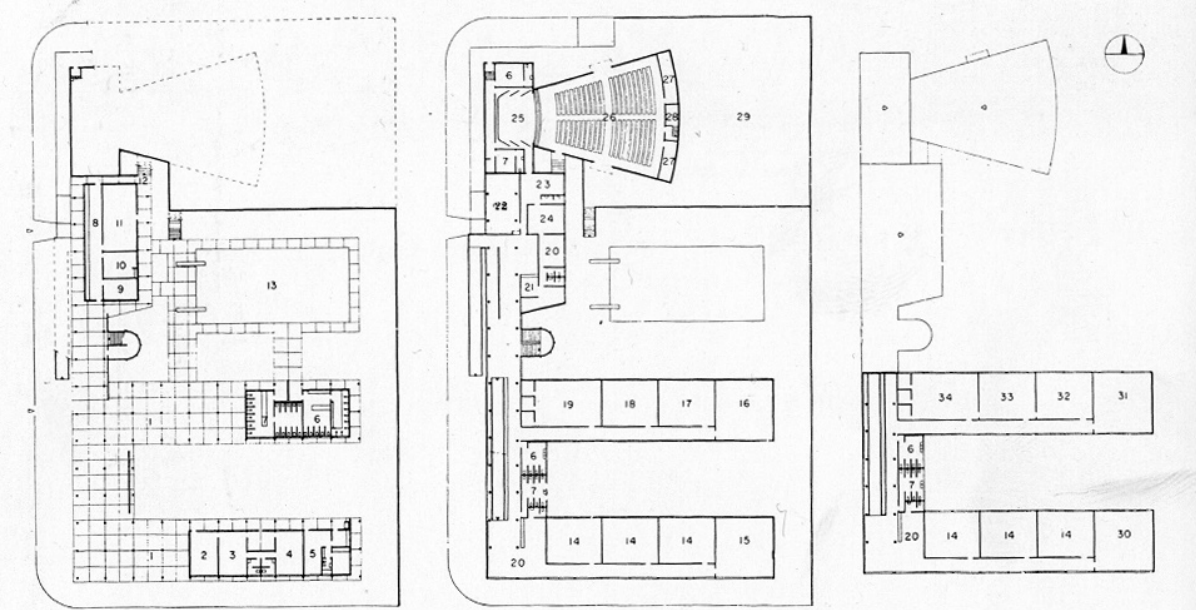

Plantas: térreo, primeiro e segundo pavimentos. 5 / escala

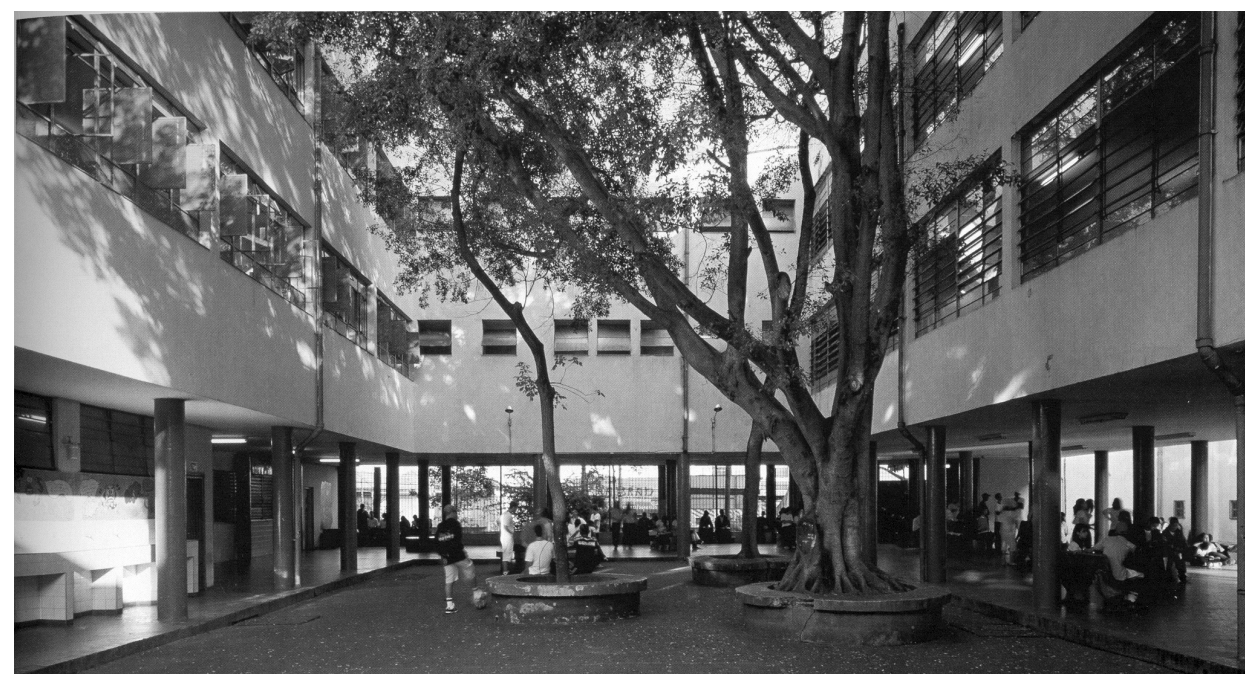




\section{EE Doutor Edmundo de Carvalho}

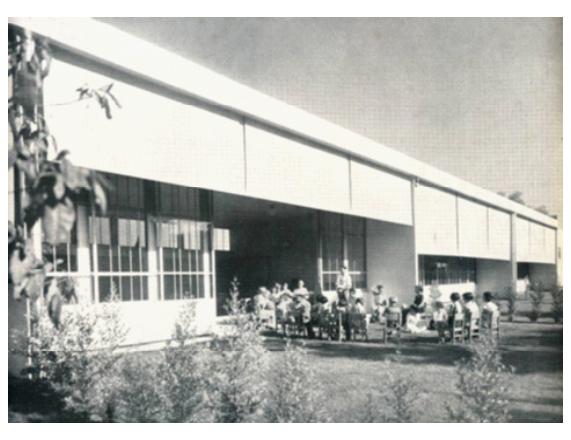

Corona School Bell. Richard Neutra, 1935
Roberto Goulart Tibau/ 1950/ Rua Tibério, 145, Lapa. São Paulo, SP

Localizada em terreno de grandes dimensões, a escola conta com dois acessos. O principal, junto a Rua Tibério e um outro na Rua Faustolo, um pavimento abaixo. Tal diferença de nível que permitiu a locação do pátio de recreação coberto sob o nível das salas de aula, em pilotis: galpão coberto equipado com palco, sala de dança, sala de ginática, cozinha, refeitório (sopa escolar), assistência social, médico, dentista, laboratório fisiológico, banheiros e almoxarifado. Esse é o espaço principal do edifício, estrategicamente posicionado em relação ao conjunto e diretamente vinculado aos outros usos da escola através de rampas, escada e galerias cobertas de circulação.

A escola contava originalmente com quinze salas de aula, nove no pavimento superior, junto ao bloco administrativo e ao acesso (sendo uma delas destinada às atividades de artes manuais) e as outras seis salas de aula implantadas diretamente ao rés do chão, junto à Rua Faustolo. Estas últimas, dispostas duas a duas em três volumes independentes, contavam com um pátio externo de mesma dimensão que permitia que as aulas pudessem ser ministradas também ao ar livre, como na Corona School Bell, projetada em 1935 pelo arquiteto Richard Neutra. Segundo ABREU (2007) essa escola "foi a única do Convênio a usar o conceito de 'aulas ao ar livre'"110. Além desses três volumes, esse corpo contava com um volume praticamente idêntico, destinado ao refeitório, que funcionava como lugar de transição entre o galpão e as salas de aula.

Uma última consideração merece acento: todas as salas de aula estão voltadas à mesma orientação, face norte, e contam com ventilação transversal cruzada. Máxima estabelecida pela equipe de trabalho que garantia, nos projetos em que podia ser concretizada, qualidades semelhantes a todas as salas de aula. 


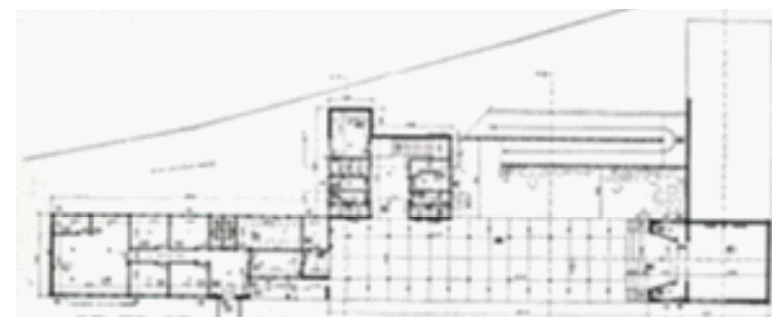

$$
\text { 1.1. }
$$
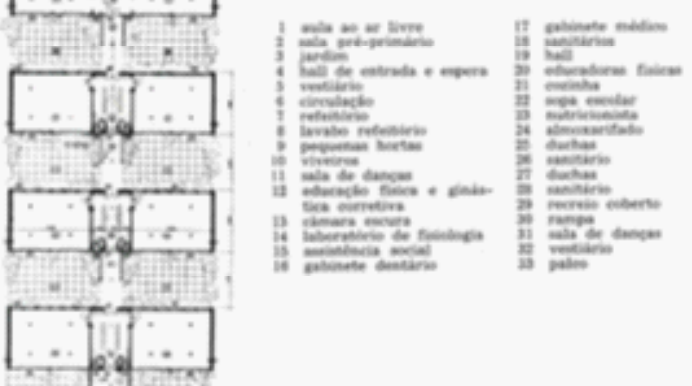

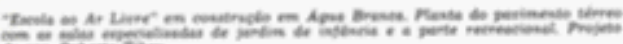

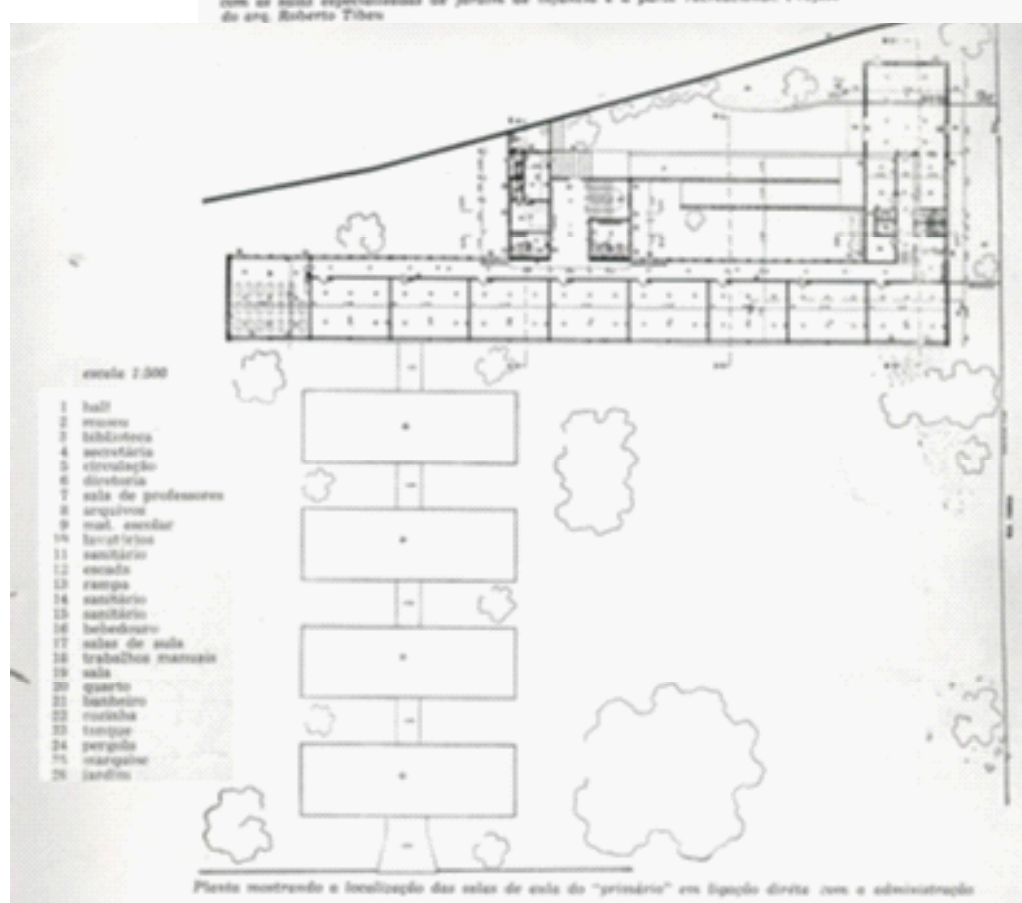



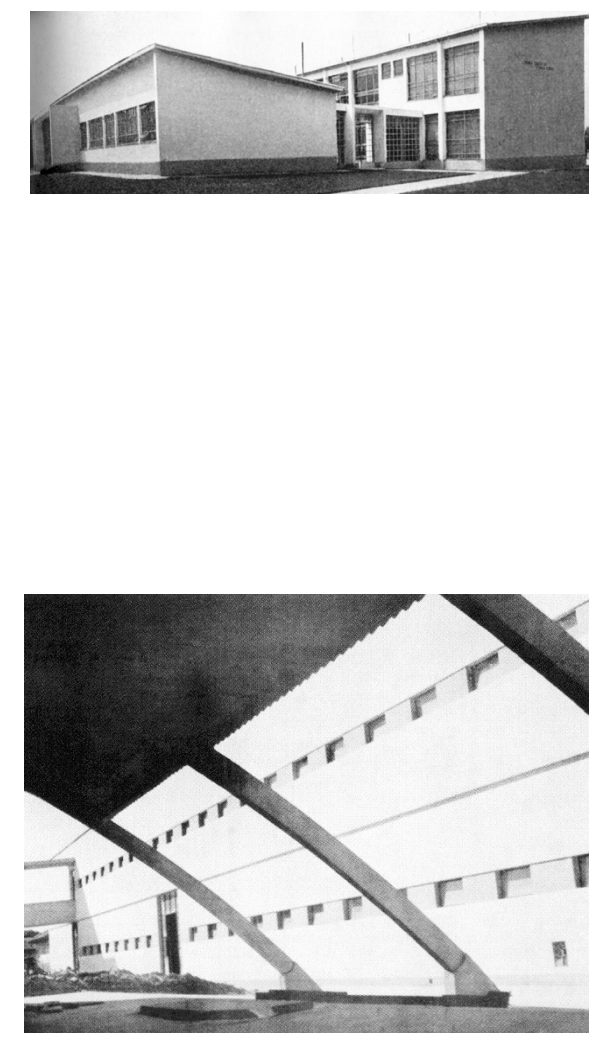

\section{EE Professeor Pedro Voss}

Ernest Robert Carvalho Mange / 1951 / Rua José de Magalhães, 477, Saúde. São Paulo, SP

A característica fundamental dessa obra é a iluminação bilateral das doze salas de aula. Elas estão agrupadas em dois pavimentos e o acesso às salas do pavimento superior é feito por escadarias, uma a cada duas salas, eliminando o corredor de circulação e permitindo grandes aberturas em ambas as faces.

\section{EE Romeu de Moraes}

\section{Oswaldo Corrêa Gonçalves / 1950 / Rua Tonelero, 407, Lapa. São Paulo, SP}

Escola que representa muito bem os princípios do grupo de trabalho. Três volumes principais articulados entre si por passagens cobertas e um volume anexo, destinado à zeladoria, desprovido de conexão coberta com o restante da escola. Os blocos administrativo e didático têm dois pavimentos e escadas independentes entre si. O galpão de recreação coberto em arcos e telha ondulada de cimento amianto é equipado com banheiros e cantina e pode funcionar independentemente dos outros blocos do edifício, ampliando as possibilidades de uso do ambiente da escola para além de suas fronteiras. 


\subsection{O Plano de Ação do governo Carvalho Pinto (1959-1963) - IPESP e FECE}

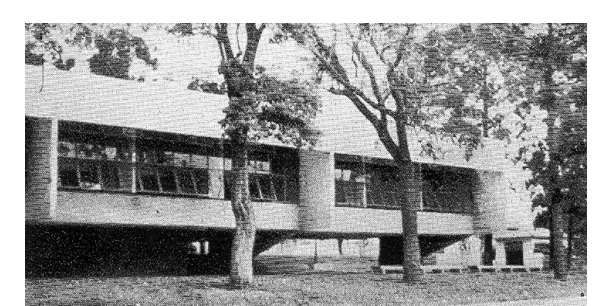

Fórum de Avaré. Paulo Mendes da Rocha, 1961

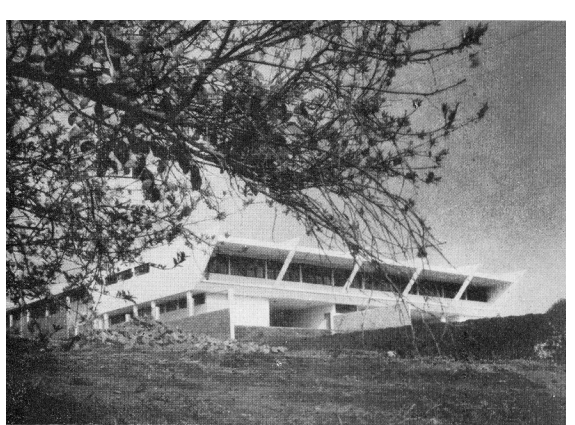

G.E. em Santa Cruz do Rio Pardo. David Libeskind, 1960
Se em 1949 a situação do ensino era precária, apesar dos esforços realizados, dez anos depois a situação era alarmante. São Paulo assistiu a um vertiginoso crescimento populacional resultante, principalmente, de movimentos migratórios. Consolidava-se na grande São Paulo um gigantesco parque industrial, especialmente da indústria automobilística, maciçamente implantada na região do $A B C$ paulista (Santo André, São Bernardo e São Caetano). As cidade necessitavam de instalações adequadas, tanto de moradia como de infra-estrutura urbana e equipamentos sociais (escolas e postos de saúde, só para citar o essencial). Entretanto, a máquina administrativa encontrava-se completamente desaparelhada para atender a contento essa demanda crescente.

Em 1959, assumiu o governo do Estado de São Paulo Carlos A. de Carvalho Pinto, cuja gestão (que se estendeu até 1963$)^{11}$ orientou-se pelas diretrizes delineadas no seu PAGE (Plano de Ação do Governo do Estado), que reorganizava vários setores da administração estadual. Naquela época, no que tange à educação, o quadro era o seguinte:

"O déficit de salas de aula era suprido com construções improvisadas de madeira e com o aumento do número de períodos de funcionamento das escolas existentes. Agravando ainda mais a situação, intensifica-se a migração da população do campo para as cidades. Além de grupos escolares faltam locais adequados para ginásios, para o ensino secundário e para as escolas normais. Esse é o panorama do ensino em São Paulo quando, em 1959, Carvalho Pinto assume o governo do Estado."12

O Brasil vivia naquele momento uma enorme euforia com o "crescimento econômico" da era JK (Juscelino Kubitschek) e, no plano da arquitetura moderna nacional, um entusiasmo equivalente devido à repercussão positiva dessa produção tanto no país quanto fora dele. Brasília, uma cidade projetada no interior do país, estava sendo construída e coroaria, de modo supreendente, esse período:

"Ao final da década de 50, o Brasil vivia um clima de grande entusiasmo em função do crescimento econômico gerado nos anos de Juscelino Kubitschek. A própria arquitetura moderna brasileira, com os sucessos das obras de Brasília, era amplamente 11 A produção mais profícua das escolas do FECE, muitas delas financiadas pelo IPESP, deu-se durante a vigência do Governo Carvalho Pinto (1959 a 1963). Dessa iniciativa participaram muitos arquitetos e escritórios de arquitetura. Dentre eles podemos destacar, além dos já citados acima, Abrahão Sanovicz, Alfredo Paaesani, Carlos Millan, David Libeskind, Eduardo de Almeida, Ícaro de Castro Mello, João Clodomiro B. de Abreu, Maurício Tuck Schneider e Pedro Paulo Saraiva.

12 FERREIRA, Avany De Francisco; CORRÊA, Maria Elizabeth Peirão; MELLO, Mirela Geiger de. Arquitetura Escolar Paulista - Restauro. Fundação para o Desenvolvimento da Educação (FDE). São Paulo, 1998, p. 32. 


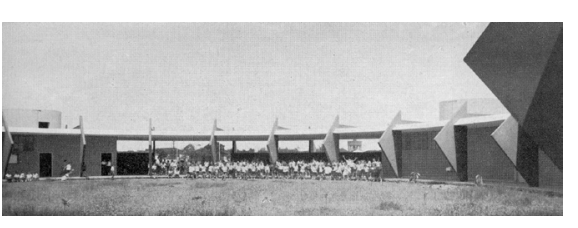

G.E. em Santos. João Clodomiro C. de Abreu, 1962.

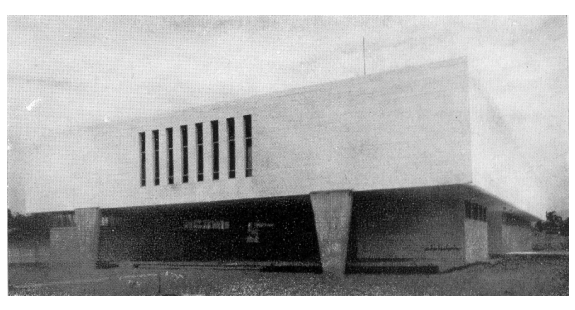

G.E. no Guarujá. Maurício Tuck Schneider, 1961
SANOVICZ (1998) afirma que o então governador de São Paulo reconheceu a oportunidade política que se oferecia a ele pela associação de sua imagem à nova arquitetura em consolidação:

"Carvalho Pinto já tinha ido à Brasília, onde se encontrou com Juscelino, que lhe mostrou o trabalho dos arquitetos. Ele entendeu esse fenômeno (da identidade da administração com os edifícios que produz). Se quisesse ter o mesmo resultado, seria necessário usar os quadros que tinha em São Paulo."14

Então os arquitetos paulistas foram convocados a participar dessa empreitada, muitos dos quais recém-formados, numa iniciativa inovadora pois até então a produção de edifícios públicos esteve praticamente vinculada ao quadro de funcionários públicos. Liderados pelo arquiteto Vilanova Artigas, uma "equipe" de profissionais se lançou a esse novo desafio: projetar os equipamentos públicos necessários, de modo a amparar a vida nas cidades e consolidar a importância social do arquiteto. Assim, fóruns, postos de saúde e principalmente escolas foram disseminadas pelo interior do Estado de São Paulo.

Num primeiro momento o IPESP (Instituto de Previdência do Estado de São Paulo) foi o órgão que custeou a execução desse novo contingente de projetos e obras contratados diretamente pelo estado. Em 1960, foi criado o FECE (Fundo Estadual de Construções Escolares), que passou a ser responsável pela elaboração, desenvolvimento e custeio do programa de construções escolares no Estado de São Paulo. Ao DOP (Departamento de Obras Públicas da Secretaria da Viação) e ao IPESP recaíam ainda o encargo de executar as obras. Em 1966 esse quadro mudou, passando o FECE a ser responsável também pela execução das obras. O FECE vigorou até 1975, quando foi substituído pela Conesp (Compania de Construções Escolares do Estado de São Paulo) e, em 1987, pela FDE (Fundação para o Desenvolvimento da Educação).

3 VALENTIM, Fábio Rago Casas para o Ensino: as Escolas de Vilanova Artigas. 2003. Dissertação de Mestrado-Faculdade de Arquitetura e Urbanismo da Unoversidade de São Paulo (FAUUSP), São Paulo, p. 80.

14 SANOVICZ, Abrahão. Depoimentos. In: Revista AU: Arquitetura e Urbanismo nº 17, São Paulo, 1998, p .56. 


\subsection{A obra precursora de Vilanova Artigas: Ginásios de Itanhaém (1959), Guarulhos (1960) e Utinga}

\section{(1961)}

SILVA (2007) analisa a diferença entre os arquitetos do Convênio os do FECE, ressaltando a dimensão política que o grupo de Artigas atribuía à escola:

“O elemento que diferencia as escolas projetadas por Vilanova Artigas daquelas do Convênio Escolar é a capacidade do projeto em revolucionar a própria idéia de escola, como um edifício com função estrita voltada para a educação. Artigas partiu de outra

premissa buscando um outro conceito, no qual a escola é parte orgânica, elemento integrador e ativo da comunidade. Essa proposta não tem sua origem no ideário da Escola Nova, de raiz humanista, mas numa crítica de base marxista que diz respeito

à conformação da sociedade brasileira, da qual a escola é parte. Essa é, a nosso ver, a raiz do desentendimento entre, por um lado pedagogos, professores e profissionais da educação, que queriam apenas educar bem, e, por outro lado, alguns arquitetos,

que pretendiam contribuir para uma transformação estrutural da sociedade.

Nesse sentido, Vilanova Artigas concebe um outro princípio ordenador, que dissolve a idéia de divisão entre espaço de circulação, de lazer e de aula, construindo um espaço organicamente integrado onde diversas atividades podiam e podem ser realizadas concomitantemente." 15

De fato Artigas (re)inventa o edifício escolar ancorado numa matriz teórica marxista, mas segundo nosso ponto de vista, incorpora muito das conquistas escolanovistas em seus projetos e obras. Assim se refere SILVA (1998) a esse respeito:

“Em 1959 veio a público o Manifesto dos Educadores mais uma Vez Convocados que, invocando as idéias do Manifesto dos Pioneiros da Educação Nova de 1932, centralizou e organizou a campanha pela educação pública.

Como em 32, o Manifesto de 59 foi redigido por Fernando Azevedo. Educadores, intelectuais liberais, liberais progressistas, socialistas, comunistas, nacionalistas, deram sustentação ao Manifesto. O documento não se preocupou com questões didático-

pedagógicas, admitindo como válidas as diretrizes "escalonovistas" de 32. Tratou de questões gerais de política educacional.

O Manifesto de 59 era favorável a existência das redes pública e particular de ensino, mas propunha que as verbas do estado fossem aplicadas somente na rede pública e que as escolas particulares se submetessem à fiscalização oficial." ${ }^{16}$

15 SILVA, Janice Theodoro da. A construção da cidadania e da escola nas décadas de 1950 e 1960. In: FERREIRA, Avany de Francisco; MELLO, Mirela Geiger (organizadoras). Arquitetura Escolar Paulista: anos 1950 e 1960. Fundação para o Desenvolvimento da Educação (FDE), São Paulo, 2006 , p. 56.

16 SILVA, Helena Aprarecida Ayoub. Conceitos, Processos e Métodos Presentes na Elaboração do Projeto de Arquitetura.1998. Dissertação de MestradoFaculdade de Arquitetura e Urbanismo da Universidade de São Paulo, p. 94. 
No Ginásio de Itanhaém as conquistas programáticas foram mantidas e as três funções (administração, recreação e salas de aula), que nas escolas do Convênio estavam separadas em edificações autônomas, foram incorporadas sob uma única cobertura. Dinâmica interessante, em que os espaços destinados à circulação, o vazio do antigo "galpão" e as áreas externas, pátios e jardins fundem-se.

Depreende-se desse projeto um profundo desejo de transformação da escola, não só do ponto de vista programático, mas também construtivo e político. Nele, como em outras obras objetos dessa pesquisa, a escola passa a ser encarada como lugar do exercício democrático, aberta para a cidade e o usufruto de seus moradores. Nesse sentido, o pátio de recreação coberto, tratado nas escolas do Convênio como "galpão" anexo, passa a ter um sentido estruturador do espaço. É incorporado ao interior da escola, articulado aos outros ambientes, abrigados todos sob um mesmo teto. Para isso o uso da estrutura porticada em concreto armado, a exemplo da escola Brasil-Paraguai e do Museu de Arte Moderna (MAM) do Rio de Janeiro, foi fundamental. Assim, os arquitetos guiados por Artigas vislumbraram na invocação da inteligência dos mais altos postos da engenharia nacional uma possibilidade para conter o atraso em que estávamos mergulhados e responder, o mais rapidamente e da melhor forma possível, à enorme demanda colocada.

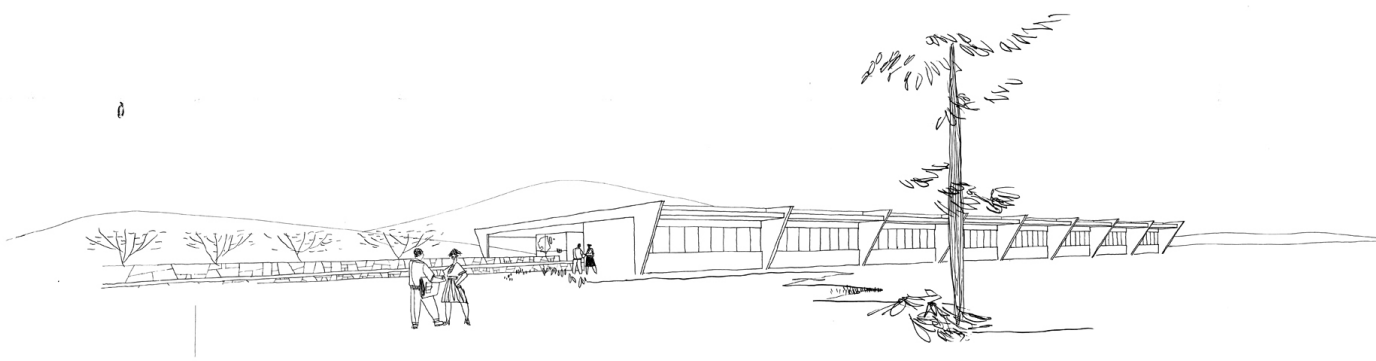




\section{EE Jon Theodoresco (Ginásio de Itanhaém) / 1959}

\section{Colaboração: Arquiteto Carlos Cascaldi}

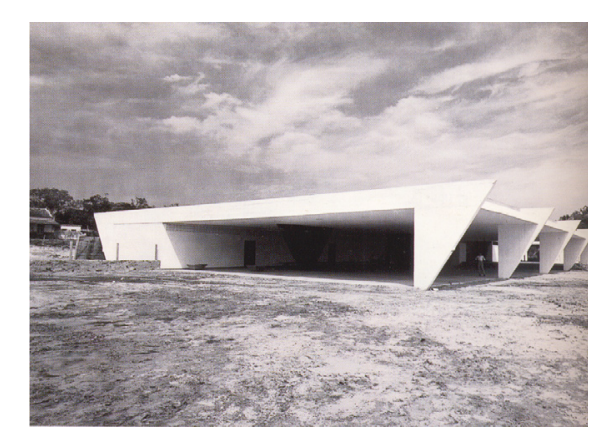

Avenida Tiradentes, Jd. Mosteiro. Itanhaém, SP.

Este edifício foi concebido como um único volume de concreto armado, composto por uma sucessão de nove pórticos estruturais intertravados que sustentam uma laje impermeabilizada (solução inovadora para edifícios desse porte na época em São Paulo). Além dos pórticos estruturais e do uso do concreto armado aparente, os pilares inclinados também fazem alusão às escolas Brasil-Paraguai e Júlia Kubitschek, já mencionadas neste trabalho. O pilar assim utilizado permite a criação de um beiral, responsável pela proteção dos caixilhos contra as intempéries tanto no bloco das salas de aula como no bloco administrativo.

Ainda em relação à estrutura, além dos pilares laterais, existe uma sequência de sete pilares no interior do edifício (dois a menos que os das laterais). Os das extremidades são perpendiculares à cobertura, recuados em relação à face do edifício, pintadas de vermelho em contraposição ao restante da estrutura branca. Na sombra esses pilares vermelhos criam a ilusão de que a laje da cobertura, esbelta, apóia-se apenas nos pilares laterais, vencendo um grande vão com uma pequena espessura.

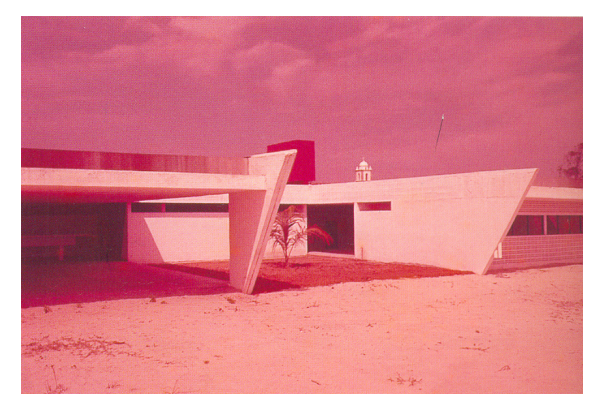

A cobertura, por sua vez, não é contínua, mas interrompida para permitir iluminação diferenciada e ventilação adequada ao espaço do pátio de recreio coberto e ao volume dos banheiros. Outra característica desse edifício é a utilização da obra de arte, um painel cerâmico de Francisco Brennand, aplicada sobre a parede recuada do bloco administrativo, na entrada da escola.

Ao tratamento do terreno, praticamente plano, o arquiteto reservou o desenho de pequenos desníveis, gerando espaços com qualidades distintas, embora abrigadas sob um mesmo teto. Há também um nítido desejo de fruição dos espaços da escola, permitida pela circulação que pode ser feita como extensão do passeio público, num emaranhado interessante entre edifício e cidade, como se não se pudesse perceber muito bem os limites entre o passeio público e o espaço da escola. 

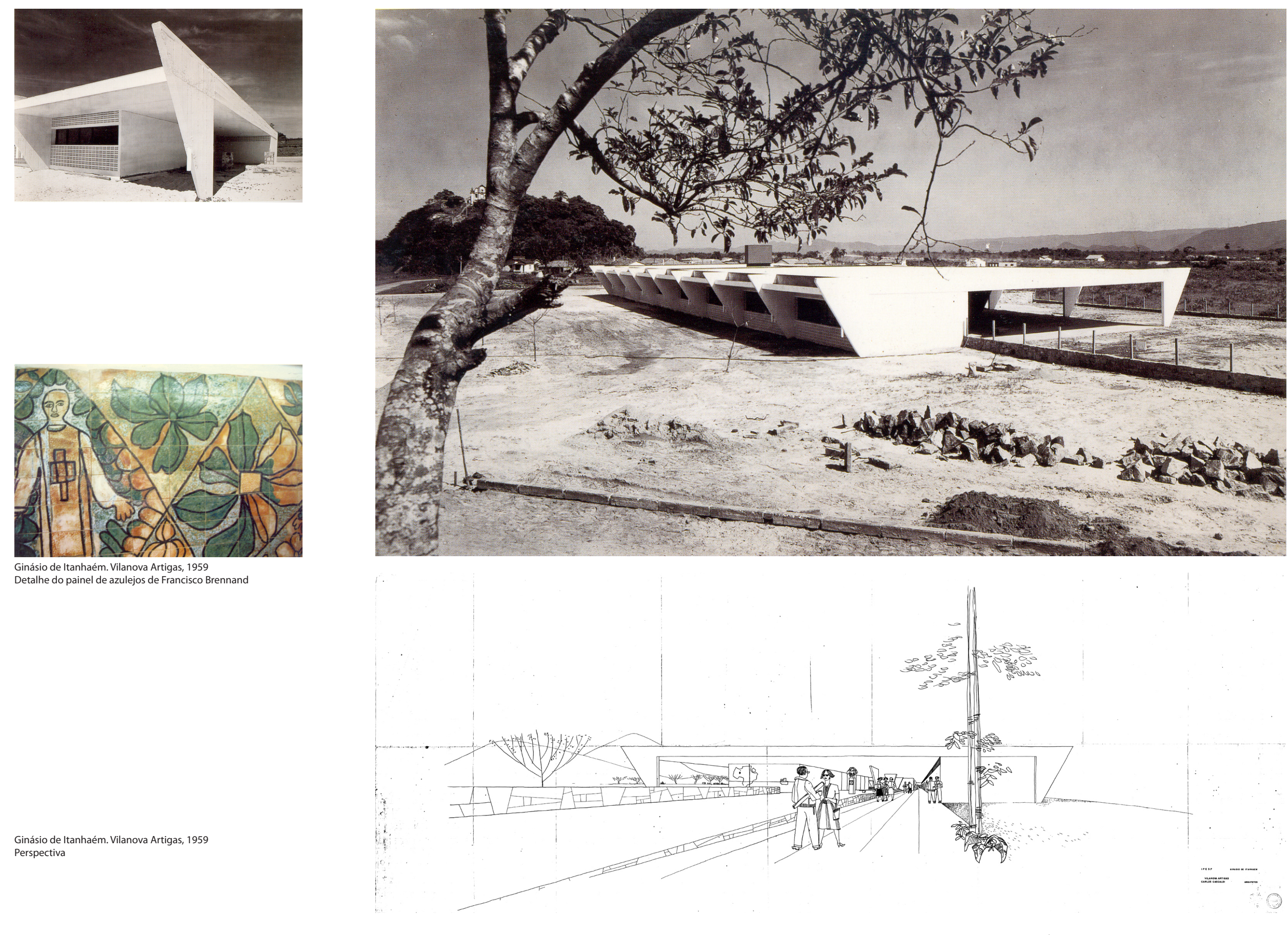


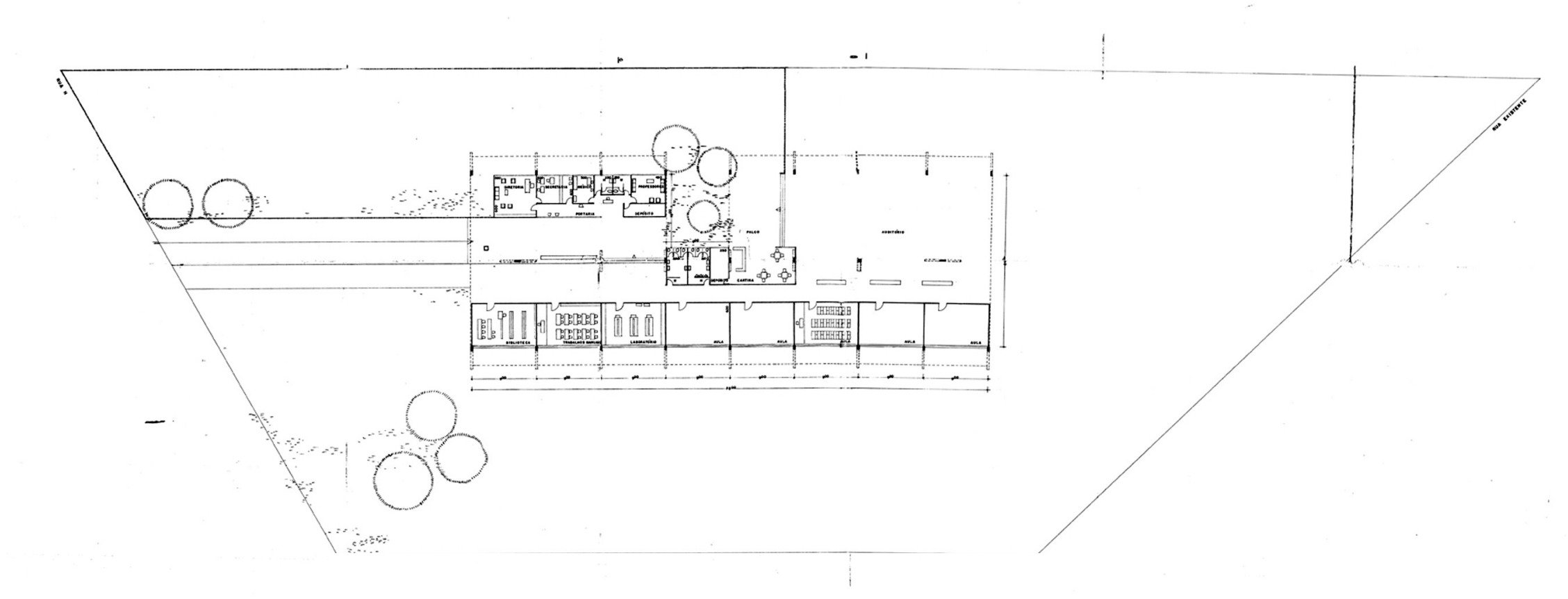

inese

curcumons

nom

"

Ysis

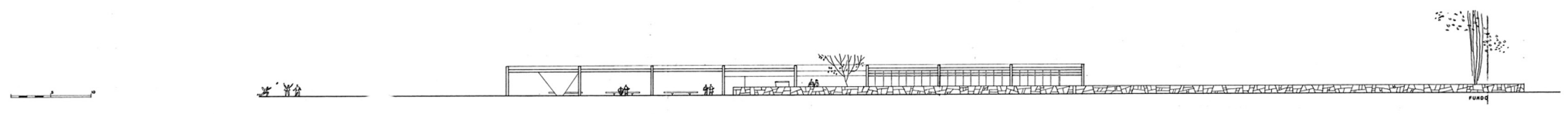

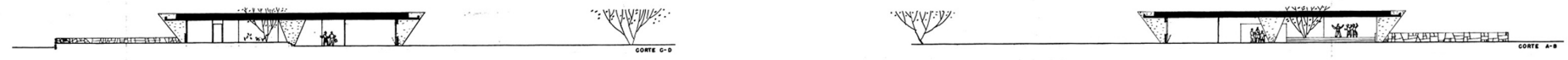




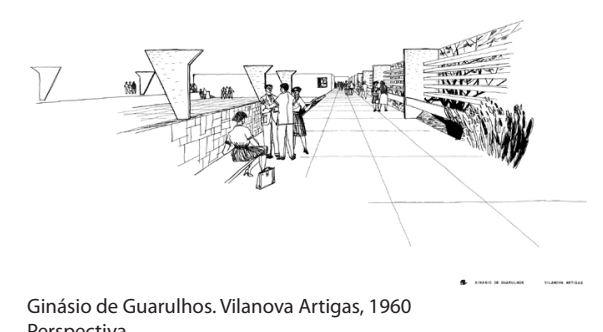

$$
\begin{aligned}
& \text { Ginásio de Gu } \\
& \text { Perspectiva }
\end{aligned}
$$

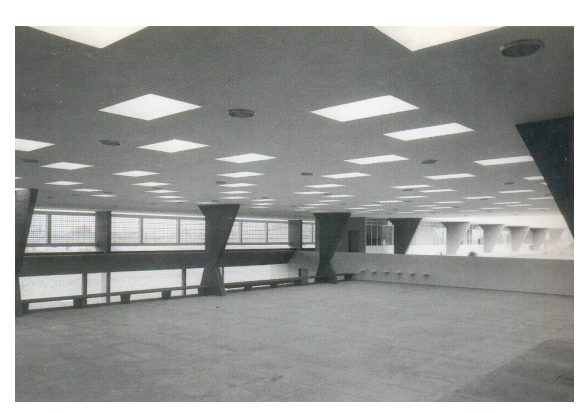

\section{EE Conselheiro Conselheiro Crispiniano (Ginásio de Guarulhos) / 1960}

Colaboração: Arquiteto Carlos Cascaldi

Rua Armindo de Lima, Vila Progresso. Guarulhos, SP.

Prisma retangular, com estrutura porticada em concreto armado como o Ginásio de Itanhaém, essa escola tem um programa mais abrangente. O número de salas de aula é maior e a escola contém, além dos elementos presentes no programa da anterior, um auditório.

O pátio de recreação coberto é o centro da escola, em posição intermediária entre o nível das salas de aula e o nível da cantina, o que lhe confere um pé-direito maior do que dos outros ambientes (de 4,50m). Esse espaço é iluminado zenitalmente através de domus, aberturas no teto para o céu, cobertos por vidros coloridos. Tudo isso, somado a um mural pintado diretamente sobre toda a superfície da parede do auditório voltada para o vazio, confere a esse espaço posição de destaque no conjunto edificado. O mural, feito pelo artista plástico Mário Gruber, trata de temas infantis como jogos, circo e brincadeiras, em consonância com o discurso de transformação do espaço escolar sugerido pelo arquiteto, onde os espaços de convívio e recreação ganham em importância.

Uma sucessão de 14 eixos estruturais compõe o edifício. Cada um deles é constituído por quatro pilares alinhados, dois numa extremidade, configurando um vão menor para os espaços de usos mais restritos (salas de aula, administração e circulações) e outro vão maior, no centro, constituindo os espaços do pátio coberto e do auditório, que necessitam de um vão maior. As formas dos pilares atribuem-lhes personalidade, são "tipos" distintos. Os das faces do edifício têm um desenho, os do interior outro e tanto uns como os outros variam em função da diferença de nível.Variações sobre um mesmo tema.

O desenho dos apoios na obra do arquiteto tem importância já reconhecida. ACAYABA (2007) faz uma observação curiosa sobre esse modo de pensar ao narrar uma orientação informal que recebeu do professor quando cursava o $2^{\circ}$ ano da FAUUSP, ainda na Rua Maranhão, enquanto fazia um projeto para uma biblioteca infantil no estúdio: 

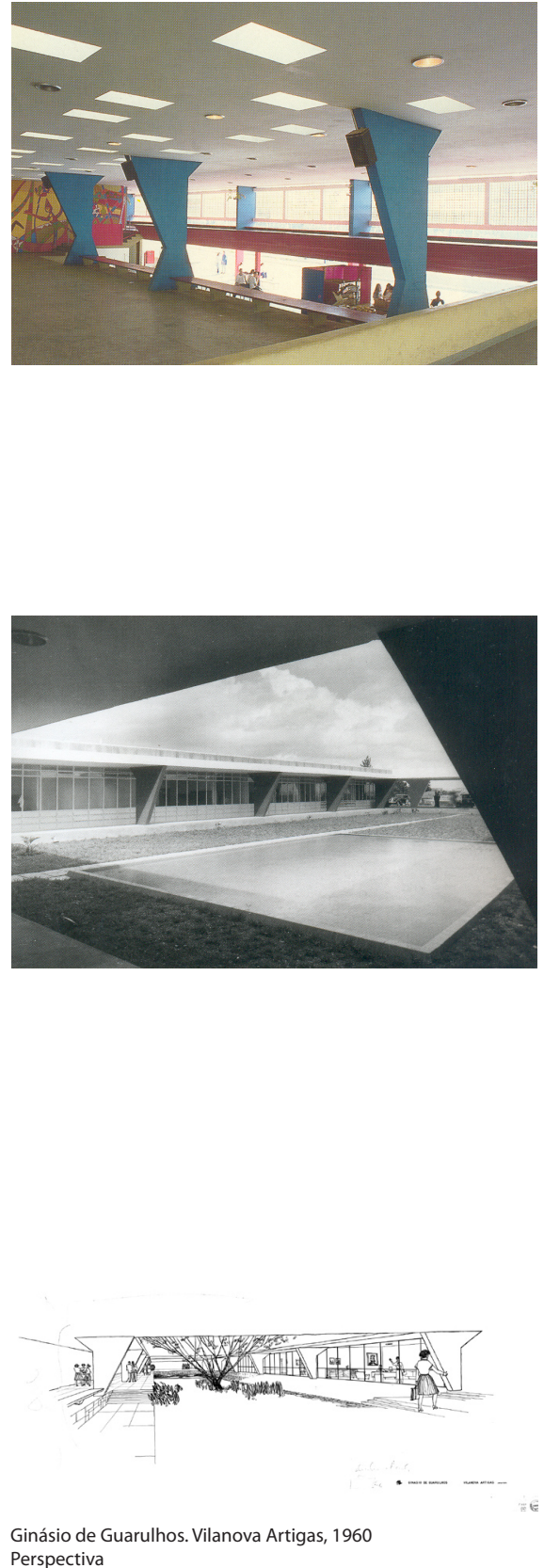

“ "Você está fazendo esses quatro pilares... Eu já fiz coisa assim, mais ainda essa forma que você está fazendo. Puxa, mas para que isso aí? Isto é uma biblioteca infantil. Fico imaginando... Até gostaria de fazer, não fiz ainda, mas, numa situação como essa, um elemento como esse pilar tem outro peso, simbólico, imagine um totem no lugar desse pilar. Fazer um totem... Que beleza! Aqui você faz outro totem! Então as crianças vão dar um nome para este, um nome para aquele." Bom... pensei: "Esse velho tá louco!”. Então, tímido, eu disse: “Não, eu gosto assim mesmo, acho que está bom”. Ele respondeu: “Bom, tudo bem, você acha... Eu gostaria de fazer do outro jeito”. Logo depois, o Artigas fez aquela casa com os troncos de árvore segurando a laje. Por acaso, o engenheiro que fez aquela obra foi o mesmo que construiu a minha casa. Ele me contava: "O Artigas é um sujeito fantástico. Além de botar aqueles troncos de árvore, sabe que tinha um tronco que ele chamava de Joãozinho... Ele dava nome aos troncos!”. O Artigas tinha uma visão diferente e a expressava claramente em seus projetos: o desenho, o caráter semântico das coisas, os símbolos..."17

A cobertura, como a do Ginásio de Itanhaém não é contínua, reserva espaços vazados para jardins internos, responsáveis também pela iluminação e ventilação adequadas aos espaços de circulação e ambientes administrativos. A circulação entre a administração e a biblioteca é uma ponte, elemento de conexão entre as atividades específicas da escola, o vazio central aglutinador e a paisagem da cidade. Uma varanda de dimensões generosas, provida de bancos e protegida por muxarabies de concreto da incidência direta da luz do sol.

“(...) tudo converge para a criação de uma nova unidade espacial no interior do prédio. Os programas específicos das atividades didáticas desenvolvem-se todos num único piso. Ao longo de toda a extensão do prédio, na face posterior, está o bloco das salas de aula, distribuídas ao longo de uma generosa circulação. No lado oposto, uma segunda circulação liga os blocos da administração, biblioteca e laboratórios, cruzando o vazio sobre a cantina e o pátio interno na forma de ponte. Nesse momento, um jogo de escadas, onde o patamar corresponde ao pátio central, conecta estrategicamente todo o conjunto. Na faixa central, entre esses dois blocos sucedem-se o jardim, o pátio de recreação coberto, o auditório, um pequeno pátio aberto com jardim e

os laboratórios.

O ginásio de Itanhaém lembra uma nave delicadamente pousada sobre o terreno. O delgado sistema estrutural de pórticos e laje plana definem o espaço interior. Na escola de Guarulhos, essa mesma idéia persiste, mas o terreno no interior da escola é totalmente recriado. Assim coexistem no edifício dois tipos de espaço, um decorrente do sistema pórtico-cobertura e outro que

17 ACAYABA, Marcos. Crônica de uma formação. In: Marcos Acayaba; textos de Hugo Segawa, Júlio Roberto Katinsky, Guilherme Wisnik. São Paulo Cosac Naify, 2007, p. 29-30. 


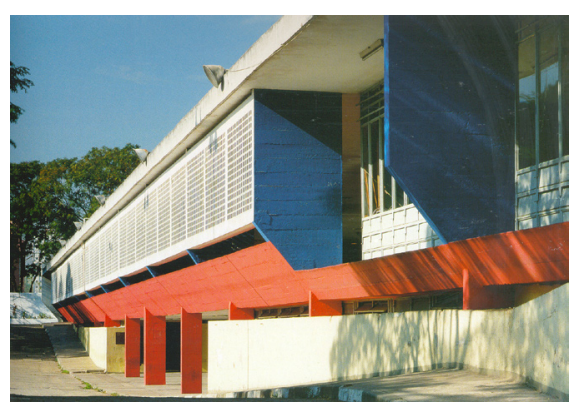

A cor foi utilizada pelo arquiteto com maestria nesse projeto, pilares azuis, com exceção dos pilares da varanda de circulação, pintados de vermelho, assim como a viga-banco de travamento, muxarabies brancos como o restante das faces do edifício, algumas alvenarias amarelas aqui e ali e o restante branco. Herança provável do contato que teve com o Grupo Santa Helena em meados de 1940, onde conviveu com artistas plásticos (pintores fundamentalmente) como Volpi, Rebolo, Bonadei e Zanini.
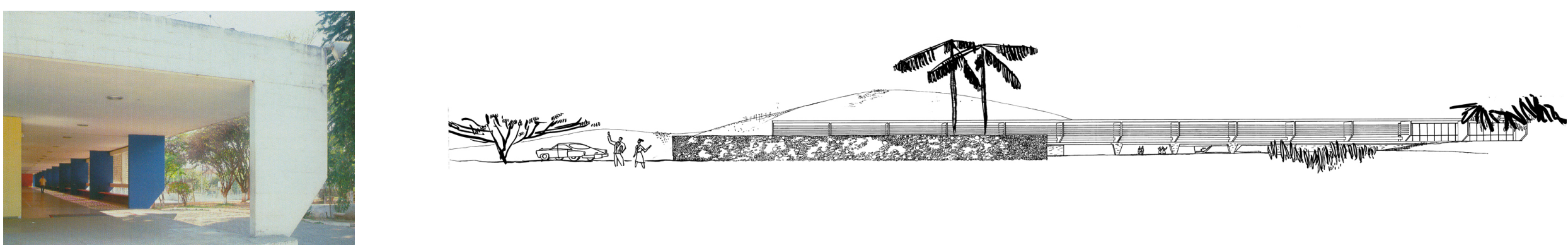

Ginásio de Guarulhos. Vilanova Artigas, 1960 Perspectiva 

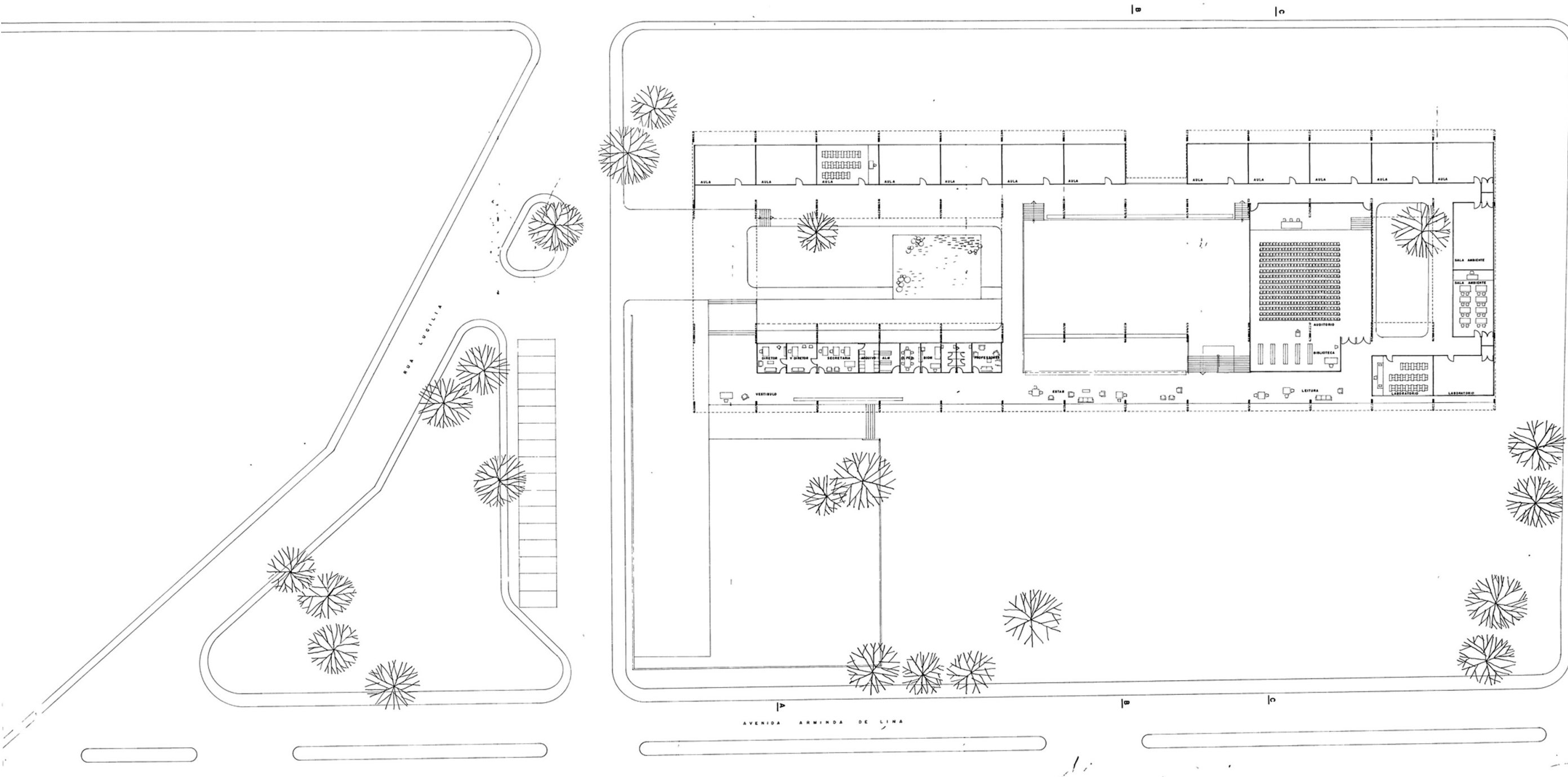

PAVIMENTO TERREO I 200
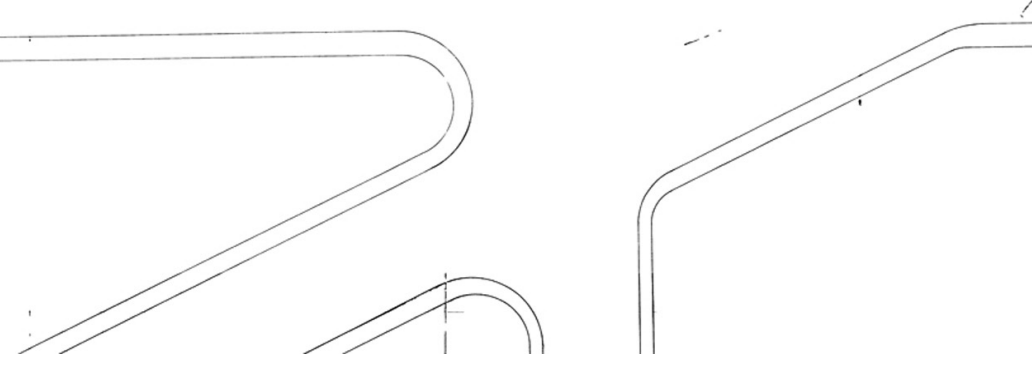

- ginasio de guarulhos vilanova artigas menume 


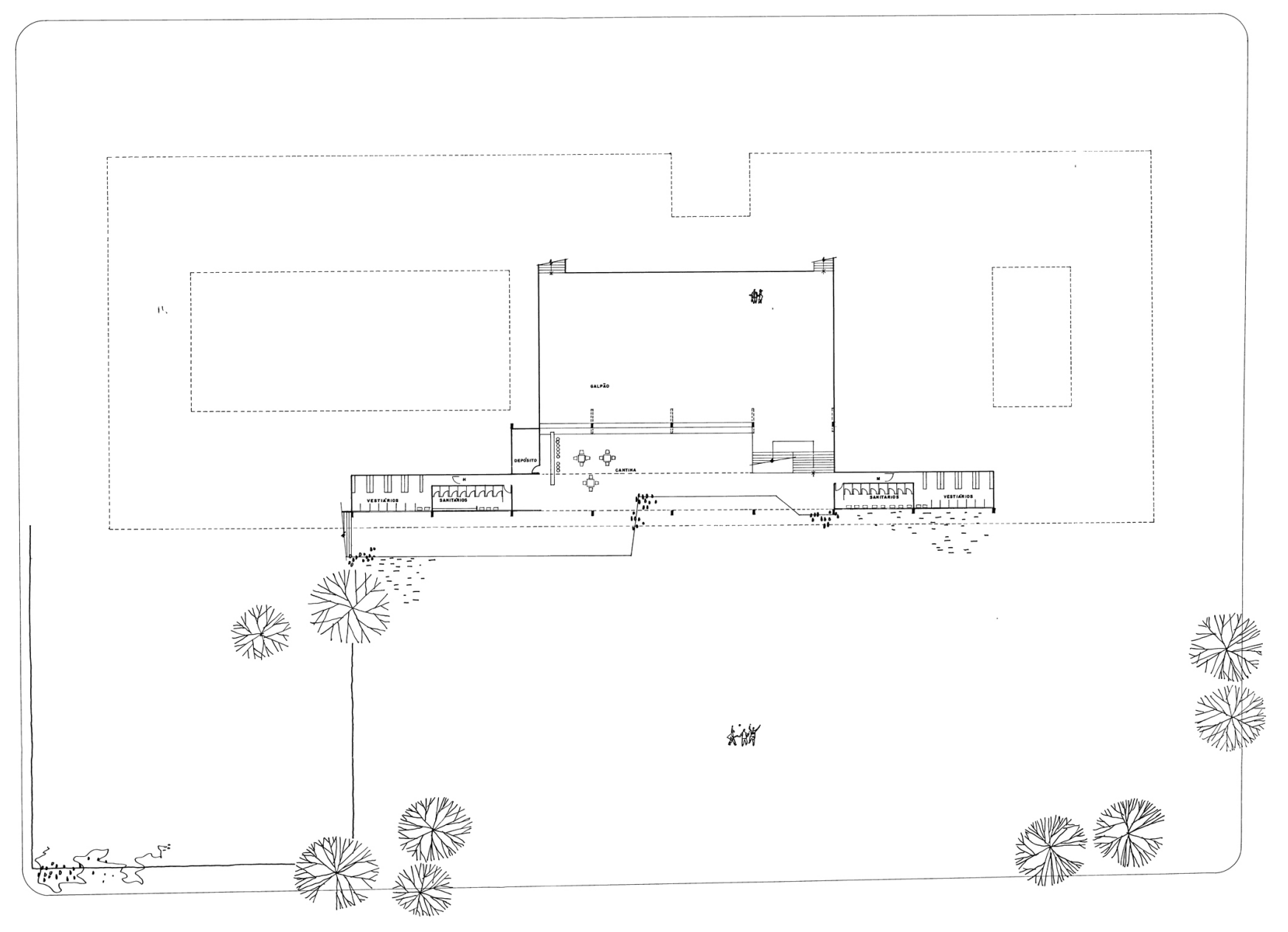




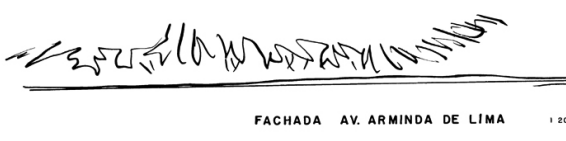
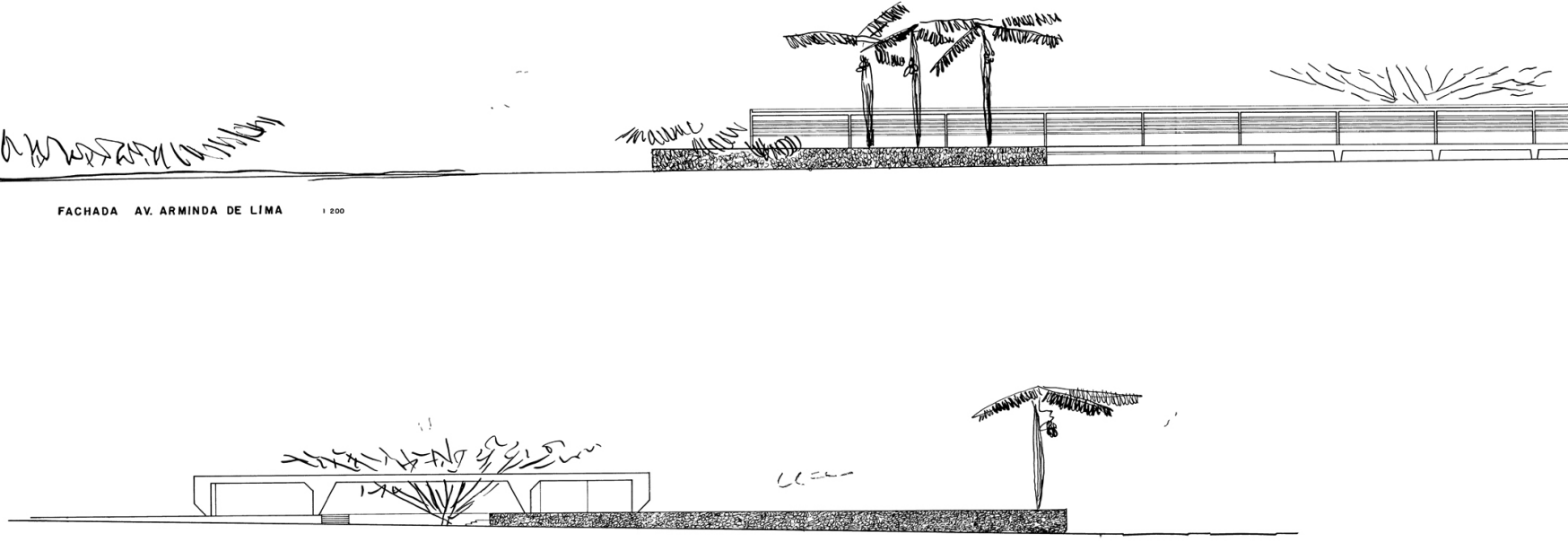

FAchado RUA LUCILIA
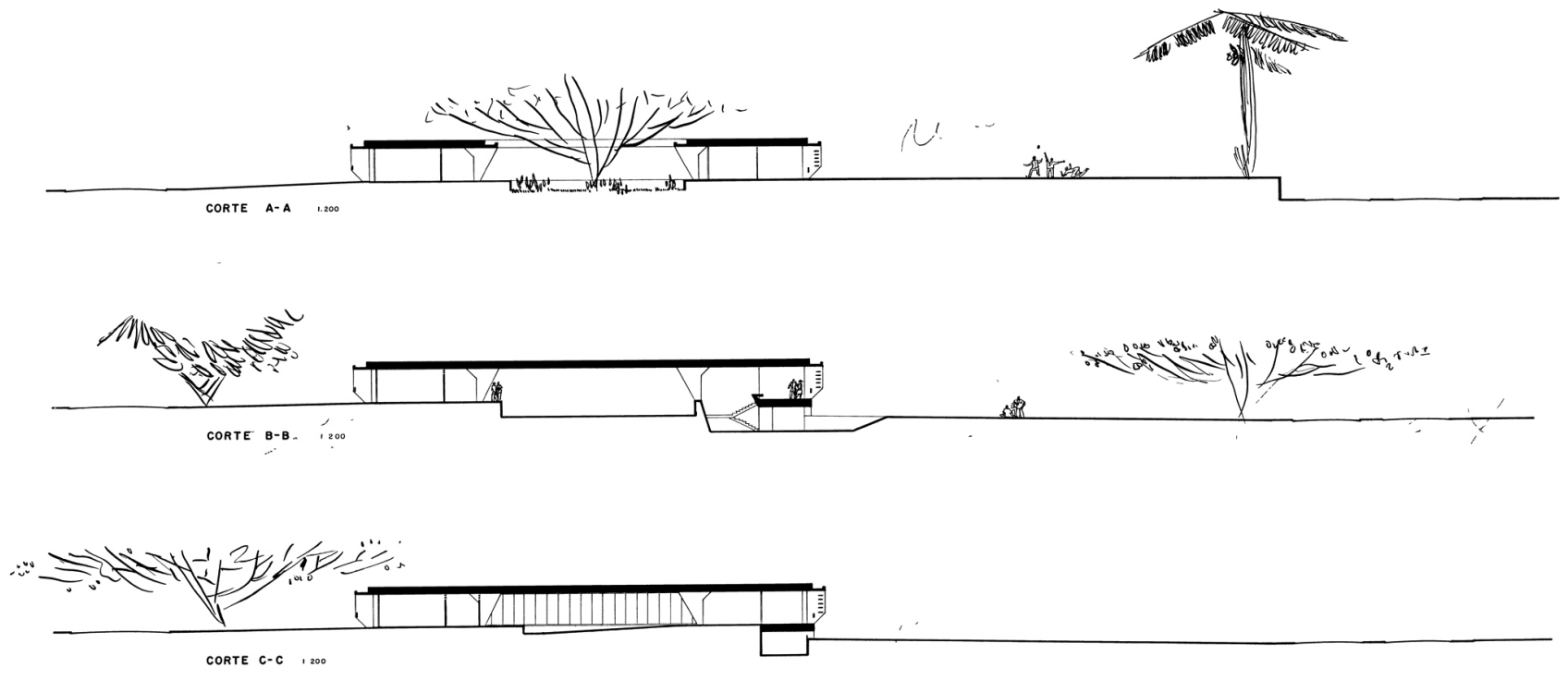

ESCOLAS PÚBLICAS EM SÃO PAULO (1960-1972)

52 


\section{EE Prof. Adamastor de Carvalho (Ginásio de Utinga) / 1962}

\section{Avenida Utinga, 1100. Santo André, SP.}
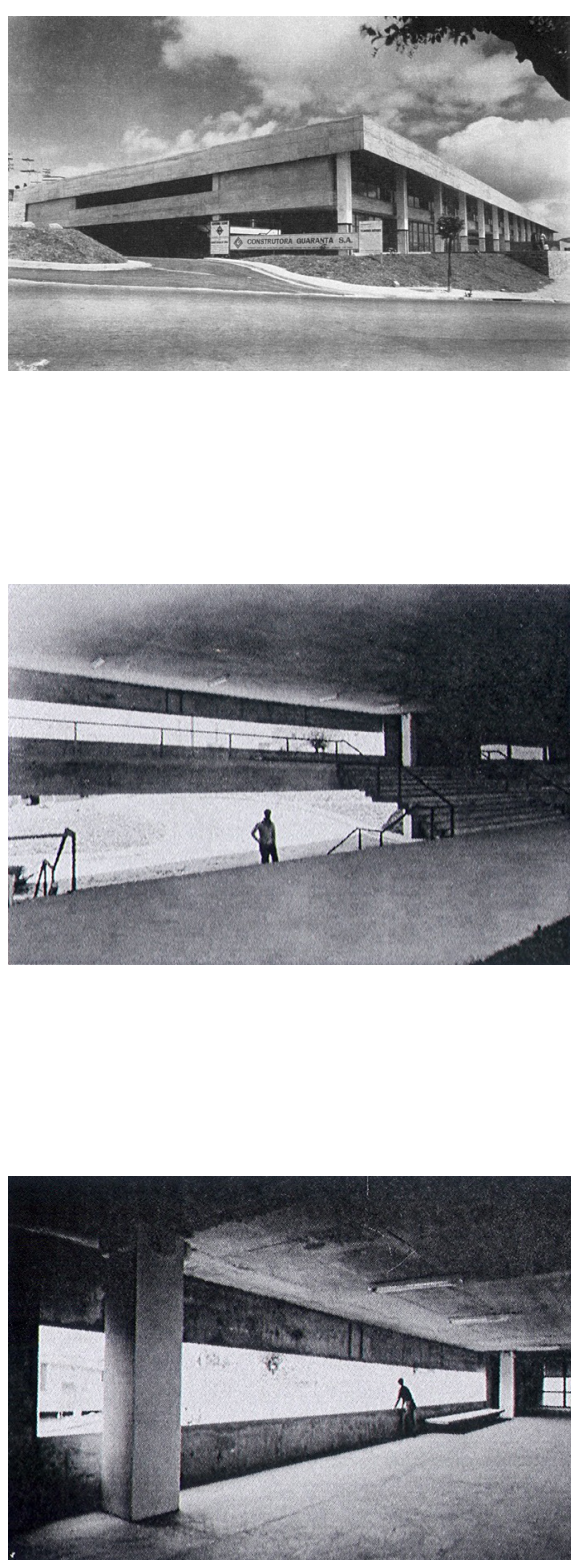

Originalmente a escola foi pensada com a estrutura pré-moldada em concreto armado e vigas protendidas cujo projeto ficou a encargo do engenheiro Roberto Zuccolo. Porém, por motivos econômicos a obra foi revisada em 1966. A estrutura passou de pré-moldada a moldada "in loco" e parte do programa foi modificado. Mesmo assim, a escola guarda espacialmente as mesmas características do projeto original e estruturalmente sugere, na simplicidade dos pilares e em sua repetição principalmente, a hipótese de pré-fabricação da construção escolar.

Em relação à utilização da pré-fabricação na estrutura, vale ressaltar que o Conjunto Residencial Zezinho Magalhães Prado, projetado em 1967 pelo arquiteto Vilanova Artigas em co-autoria com Paulo Mendes da Rocha e Fábio Penteado, foi uma outra experiência que apontava também para a importância da participação da indústria no processo construtivo de todos os equipamentos necessários à vida das pessoas nas cidades. Tanto a casa como a escola eram pensadas da mesma forma, como se a experiência de um projeto pudesse servir à elaboração do outro, mesmo que de programa diferente, num processo dinâmico de criação.

O Ginásio de Utinga lembra muito a organização espacial do ginásio de Guarulhos: dois blocos paralelos separados por um vazio que ora é jardim, ora pátio de recreação coberto, em nível intermediário em relação ao térreo, ora é a quadra no nível do chão. No térreo encontram-se parte da administração, cantina, grêmio, laboratórios, sanitários, vestiários e zeladoria; no pavimento superior, o restante da administração, as salas de aula, auditórios e laboratórios:

“O espaço interno, com seus vãos generosos, faixas contínuas de iluminação zenital, pontes que cruzam o pátio num único vão, as circulações abertas que parecem flutuar sobre os jardins, cortinas de vidro sempre protegidas por largos beirais, e a enorme "gola" de alvenaria que envolve a quadra, revelou-se dos mais belos espaços projetados pelo arquiteto.

A solução dada para a cobertura do pátio de recreação e da quadra esportiva merece atenção. Artigas desenhou uma única peça de concreto (hiperestática), pré-moldada e em forma de " $\mathrm{t}$ ", que funciona aplicada em posições alternadas. Consegue assim que uma cumpra o papel de calha, e a seguinte o papel de shed. Para que o desenho efetivamente funcione, foi preciso dobrar levemente as abas do "t", conformando a calha e simultaneamente o shed. Na colocação, essa dobra faz com que a peça apóie- 


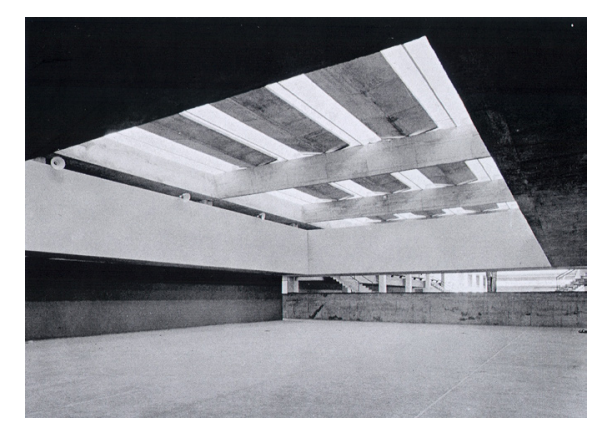

se delicadamente no centro, descolando as abas laterais. Além da delicadeza da solução, garantiu-se ventilação permanente em toda extensão da cobertura e evitou-se o uso de peças translúcidas, uma vez que a luz entra rebatida nas peças de concreto. Entretanto, durante a obra, alterou-se o sentido dessa cobertura, originalmente desenhada para vencer todo o vão central. A construção revela que foram estendidas vigas-calha de concreto entre os pilares, fazendo com que as peças pré-moldadas da cobertura ficassem bem menores do que no projeto inicial." ${ }^{19}$

O Ginásio de Utinga foi a última escola em que o arquiteto contou com a participação de um artista plástico. Uma escultura metálica foi especialmente projetada e executada por Caciporé Torres para ela e é parte intrínseca do pátio de recreação coberto da escola, como um monumento em praça pública.

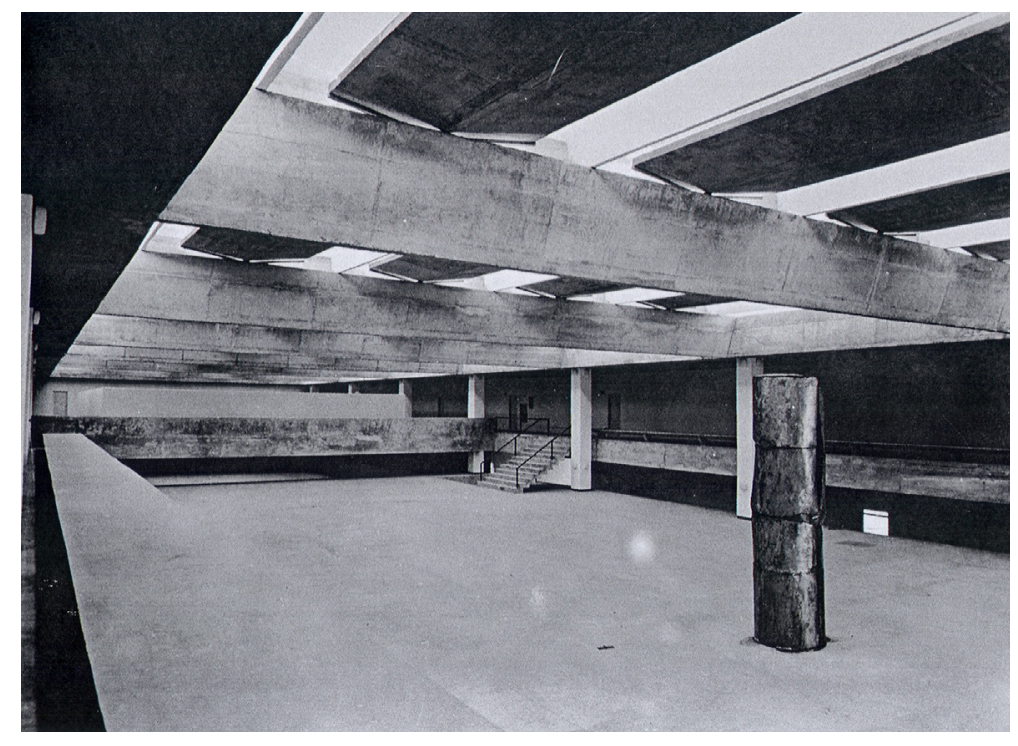




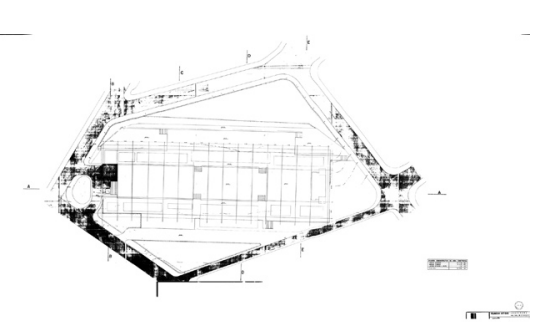

Ginásio de Utinga. Vilanova Artigas, 1962 Situação s/ escala

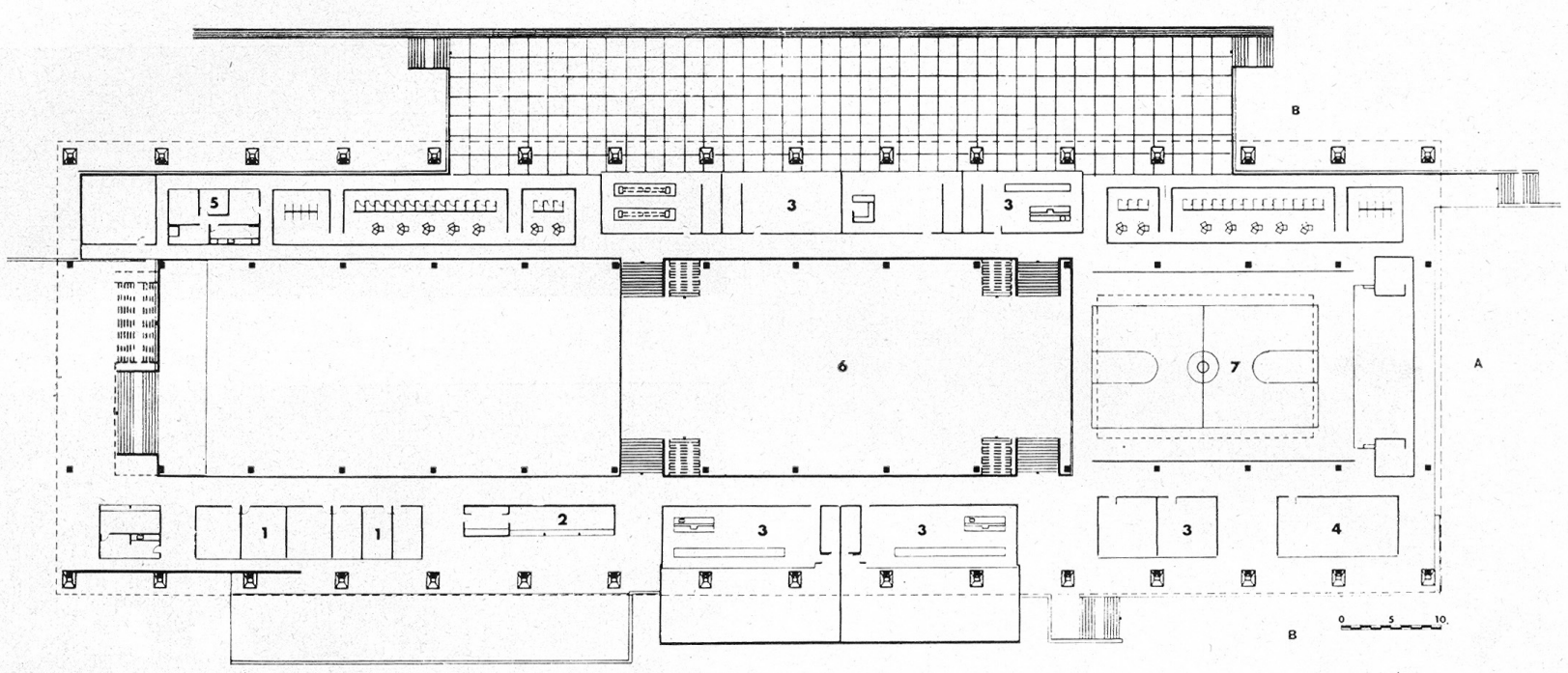

Pavimentos térreo e superior: 1 - Administração; 2 - cantina; 3 - sala de aula; 4 - grêmio; 5 - zelador; 6 - pátio; 7 - esportes

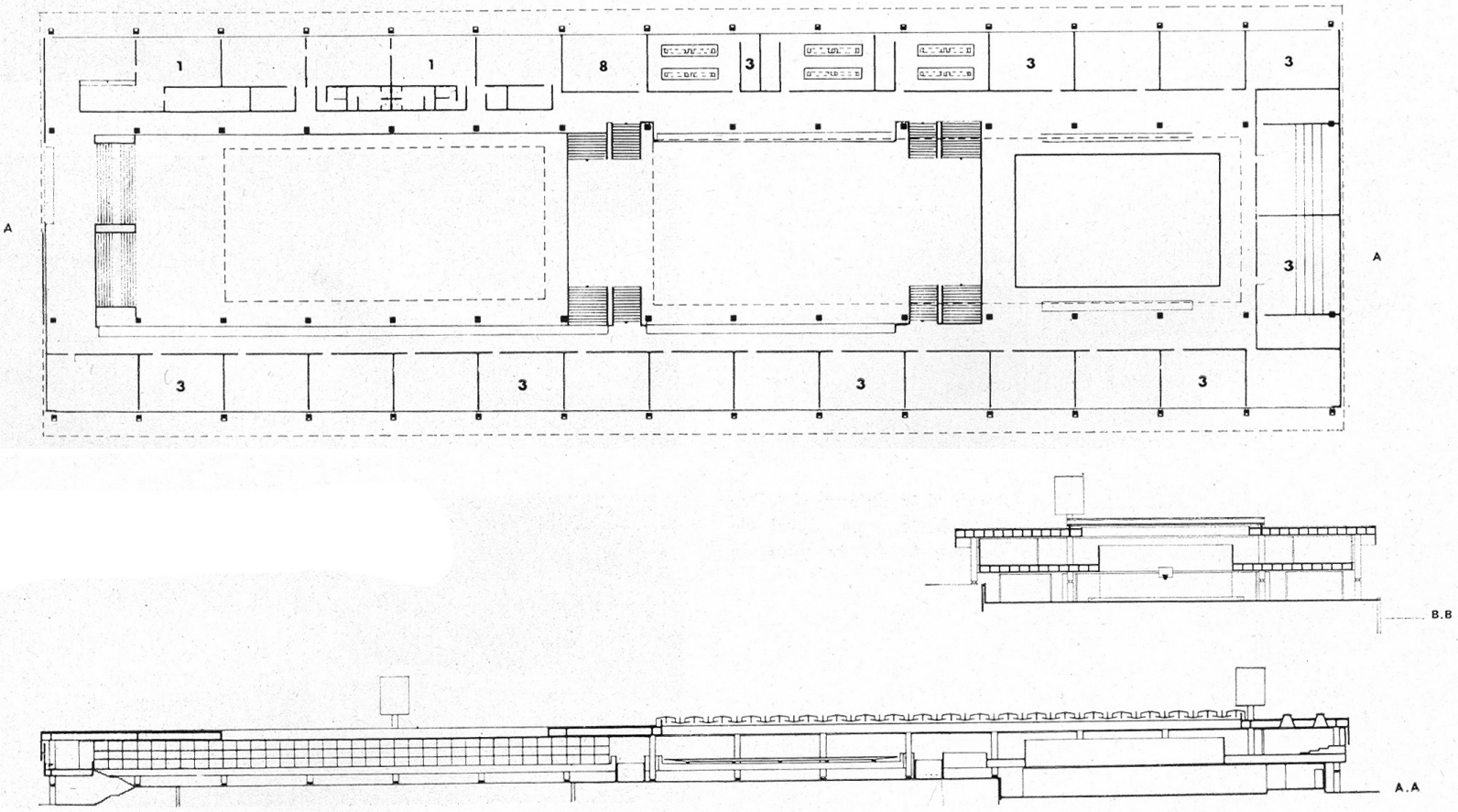



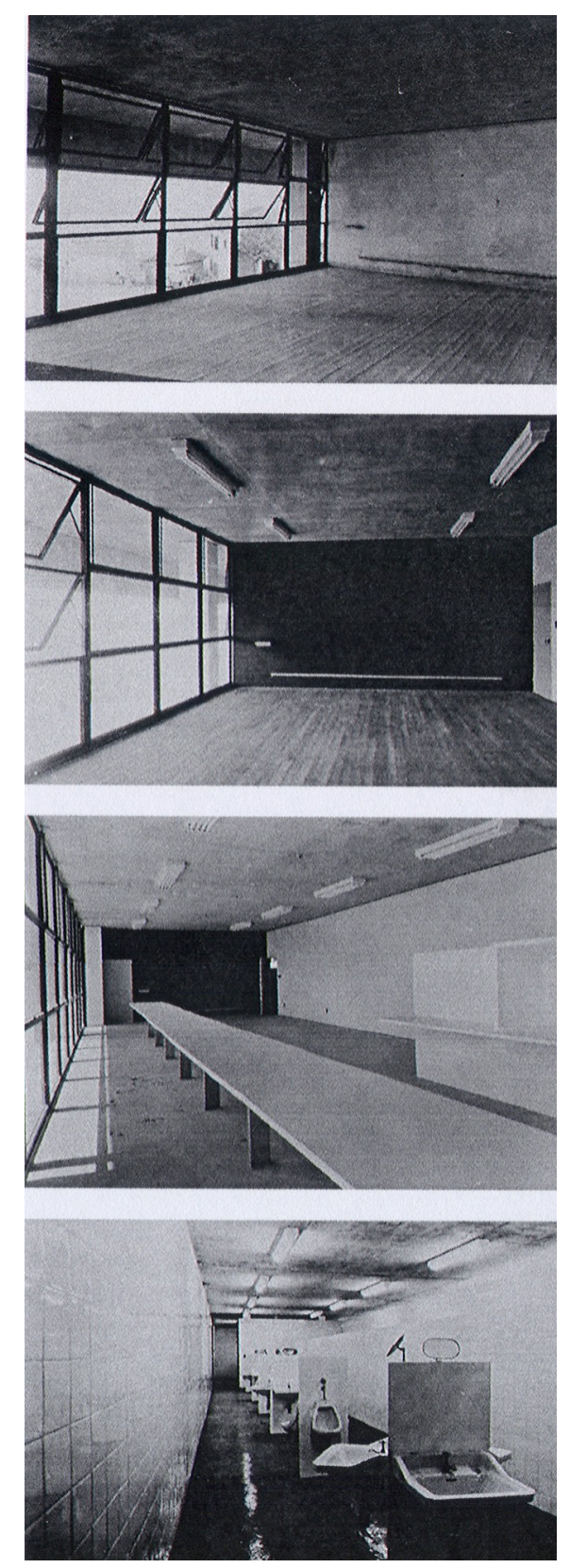
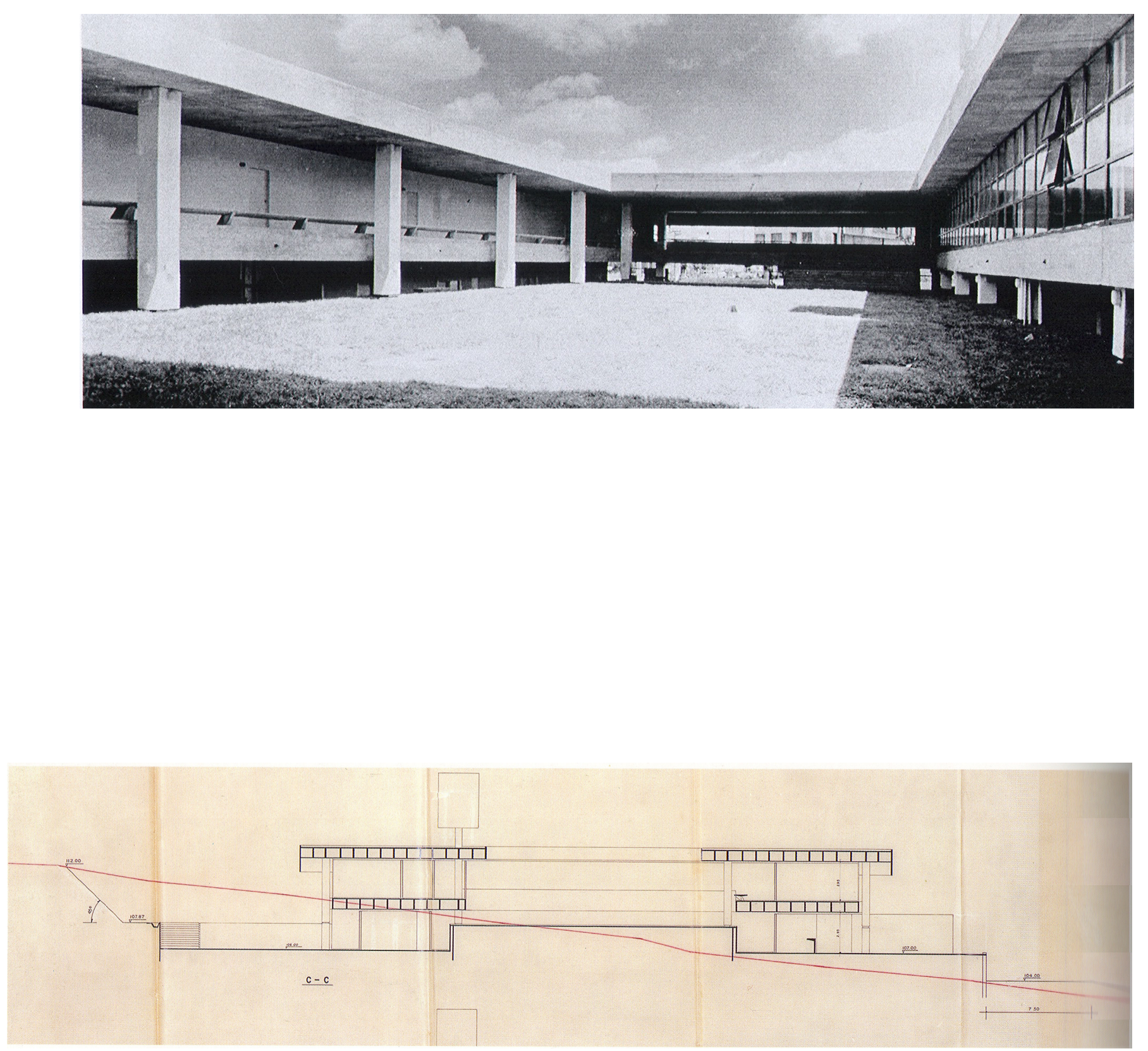
Capítulo 03: As escolas 


\section{EE Antônio Vilela Junior / 1960}

Rua Conselheiro Gomide s/n, Vila Industrial. Campinas, SP

Arquitetos: Paulo Mendes da Rocha e João Eduardo de Gennaro

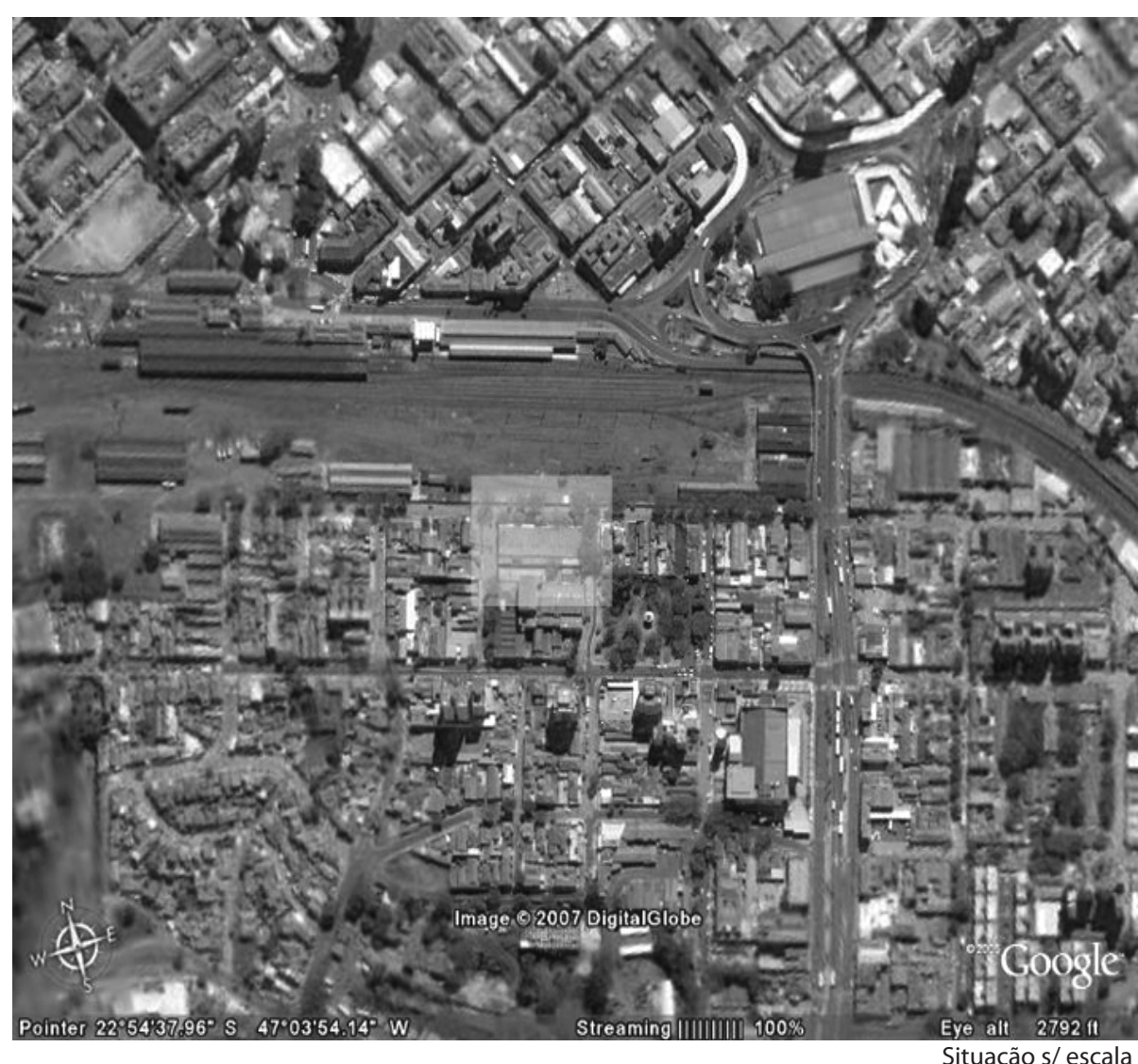




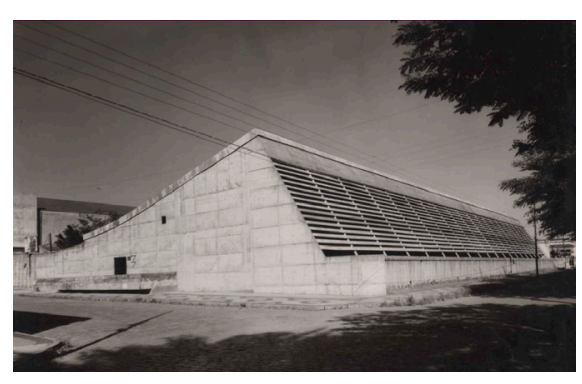

Primeira escola projetada pelo arquiteto para o Governo do Estado de São Paulo através do IPESP (Instituto de Previdência do Estado de São Paulo), situa-se em quadra institucional da cidade de Campinas.

O projeto previu a localização das salas de aula (18 ao todo, sendo duas delas destinadas ao pré-primário) voltadas ao norte, para o leito da ferrovia. As áreas destinadas à administração e serviços voltam-se ao sul, para um pátio externo. Um vazio separa os blocos de salas de aula dos de serviço e administrativo. Trata-se de pátio coberto, iluminado zenitalmente, que funciona como um espaço de recreio e conexão entre as ruas Rangel Pestana e Conselheiro Gomide.

Interessa salientar, nessa escola, a ocupação de toda extensão do lote. As paredes divisórias situam-se praticamente no limite do terreno, configurando a calha das ruas. Duas rampas simétricas e opostas garantem o acesso ao pátio através de pequenas portas. Um acesso é o administrativo e o outro, o de alunos. Assim, duas paredes paralelas e perpendiculares à rua Francisco Teodoro definem o lugar da escola no território. Sobre elas uma cobertura é apoiada, configurando a sombra necessária. Ao Norte abrem-se as salas de aula, protegidas da incidência direta da luz do sol por brises horizontais metálicos. No centro, há o pátio de recreação coberto e, ao sul, administração, banheiros, cozinha e refeitório. Os ambientes comunicam-se entre si e aos pátios e jardins externos por generosas aberturas. Outra característica dessa escola é o desenho da cobertura em uma água com uma leve curvatura que permite abrigar, em dois pavimentos e no mesmo alinhamento, o bloco das salas de aula, nove salas no pavimento térreo (entre elas duas destinadas ao pré-primário) e nove salas no pavimento superior. Duas escadas em dois lances, posicionadas em pólos opostos do edifício, comunicam o piso do recreio à galeria de circulação das salas de aula do piso superior, que por sua vez, relaciona-se como uma varanda com o piso inferior.

A cobertura é dividida em dois trechos, o primeiro abriga as salas de aula e o vazio e o outro, as outras funções, desempenhando o papel de calha, receptáculo das águas derivadas da inclinação do primeiro trecho. A laje de concreto impermeabilizada e as aberturas zenitais são elementos dessa escola que aparecem também no Ginásio de Itanhaém1 e no Ginásio de Guarulhos, projetos de Vilanova Artigas. A proximidade projetual entre a escola de Campinas e o Ginásio de Itanhaém também se faz presente na organização do programa no espaço: o bloco das salas de aula voltadas a uma mesma orientação, um vazio separando-as dos blocos admininistrativo e de vivência

\footnotetext{
1 O ginásio de Itanhaém, projetado um ano antes que a EE Professor Antônio Vilela Junior, foi a primeira escola construída com laje plana impermeabilizada, como grande parte das escolas que se seguiram a ela.
} 
e pequenos desníveis configurando espacialidades específicas.

O Ginásio de Guarulhos, projetado no mesmo ano que a escola de Campinas, é conhecidamente a primeira escola em que Artigas utilizou aberturas zenitais. Na de Campinas, as aberturas zenitais foram propostas por Paulo Mendes da Rocha como sheds (aberturas verticais na cobertra orientadas para uma única face de insolação) voltados ao Sul, localizados no primeiro trecho da cobertura, garantindo iluminação uniforme no vazio central.

A estrutura da escola é feita de concreto armado moldado "in loco" (como todas as outras escolas eleitas nesse catálogo). O módulo estrutural é pautado pela largura das salas de aula (como também veremos mais adiante nas outras escolas). A largura da sala é de $7.00 \mathrm{~m}$ e o módulo entre eixos, $7.15 \mathrm{~m}$. As aberturas das salas de aula, bem como as do bloco administrativo, foram pensadas como caixilhos metálicos e de madeira com vidros transparentes de piso a teto, o que permite uma relação desobstruída entre interior e exterior.

Atualmente a escola encontra-se em péssimo estado de conservação. Algumas alterações comprometram a dignidade do espaço original. Uma delas foi a modificação dos caixilhos das salas de aula, previstos como panos de luz totais, de piso a teto e de parede a parede, agora reduzidos em sua dimensão vertical, o que implicou numa significativa redução da relação prevista entre interior e exterior, principalmente nas salas de aula diretamente vinculadas ao nível do chão, junto ao jardim. Outra alteração significativa foi a ocupação de parte do vazio junto à administração, diminuindo a incidência de luz no interior do edifício e prejudicando a relação entre espaços de recreio coberto e descoberto. 


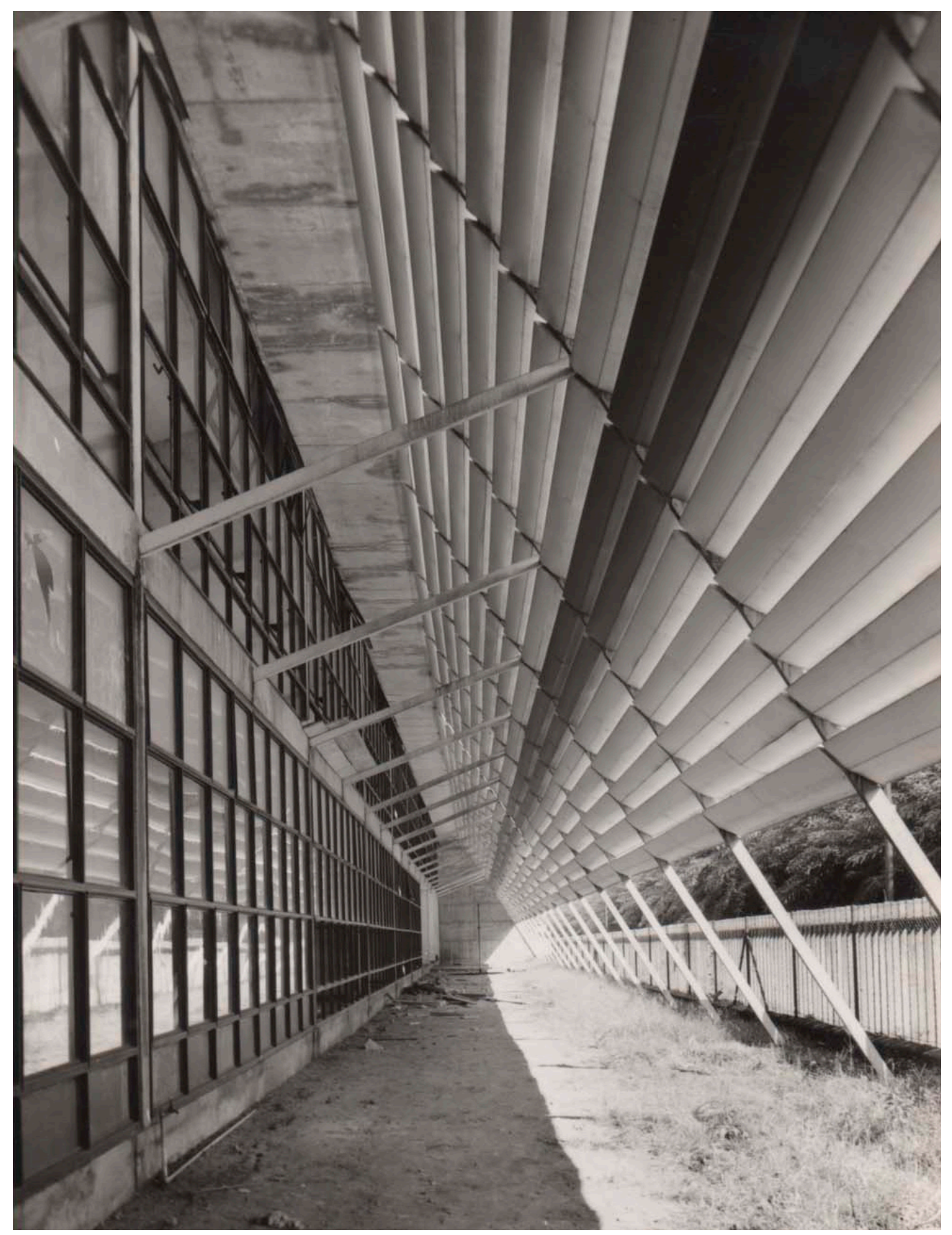


RUA FRANCISCO TEODORO
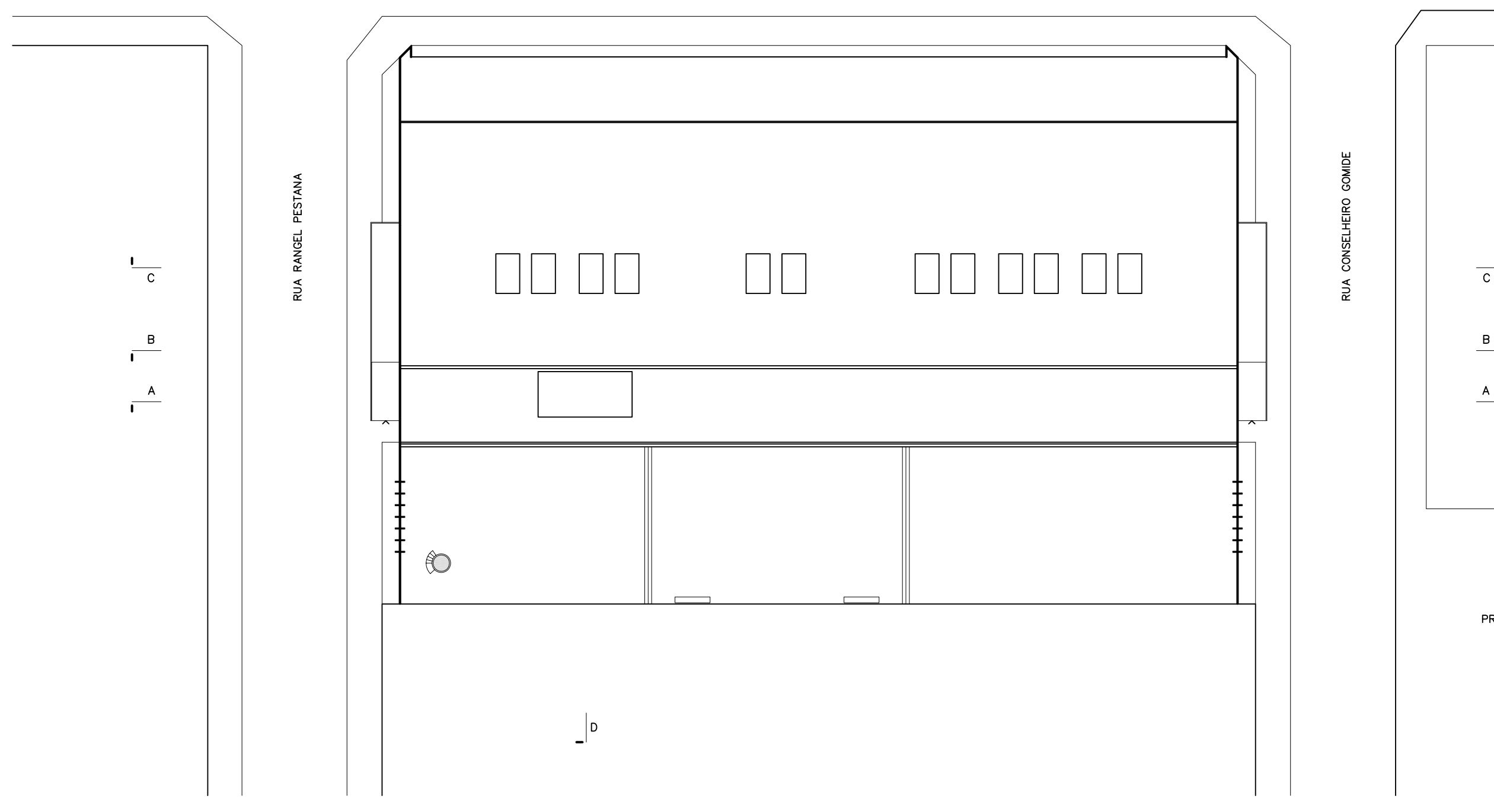

$\frac{1}{c}$

$\mathrm{B}$

A

PRAÇA CORREA DE LEMOS

PLANTA DE COBERTURA ESC. 1:500 
RUA FRANCISCO TEODORO
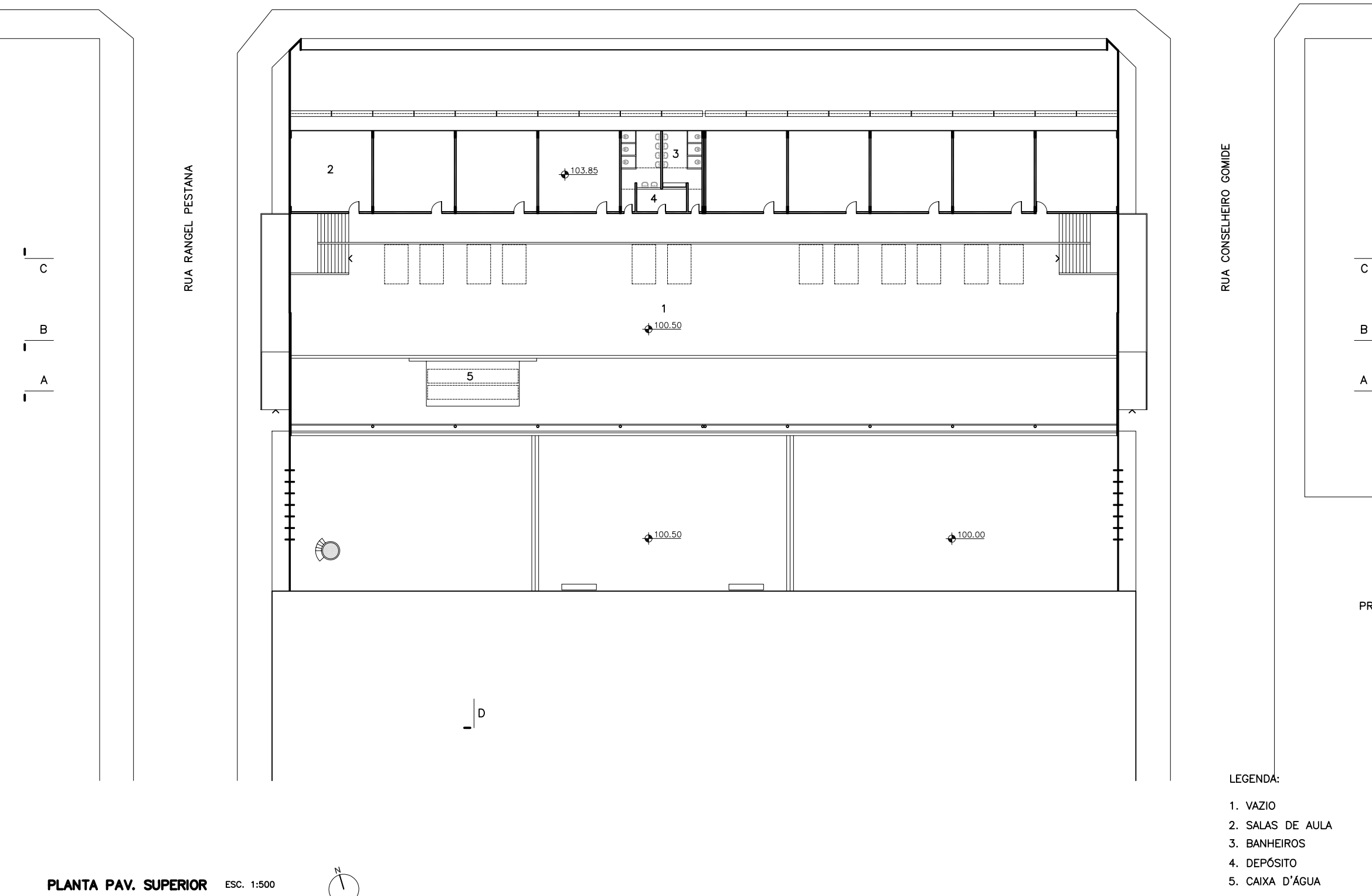

PLANTA PAV. SUPERIOR ESC. 1:500 
RUA FRANCISCO TEODORO
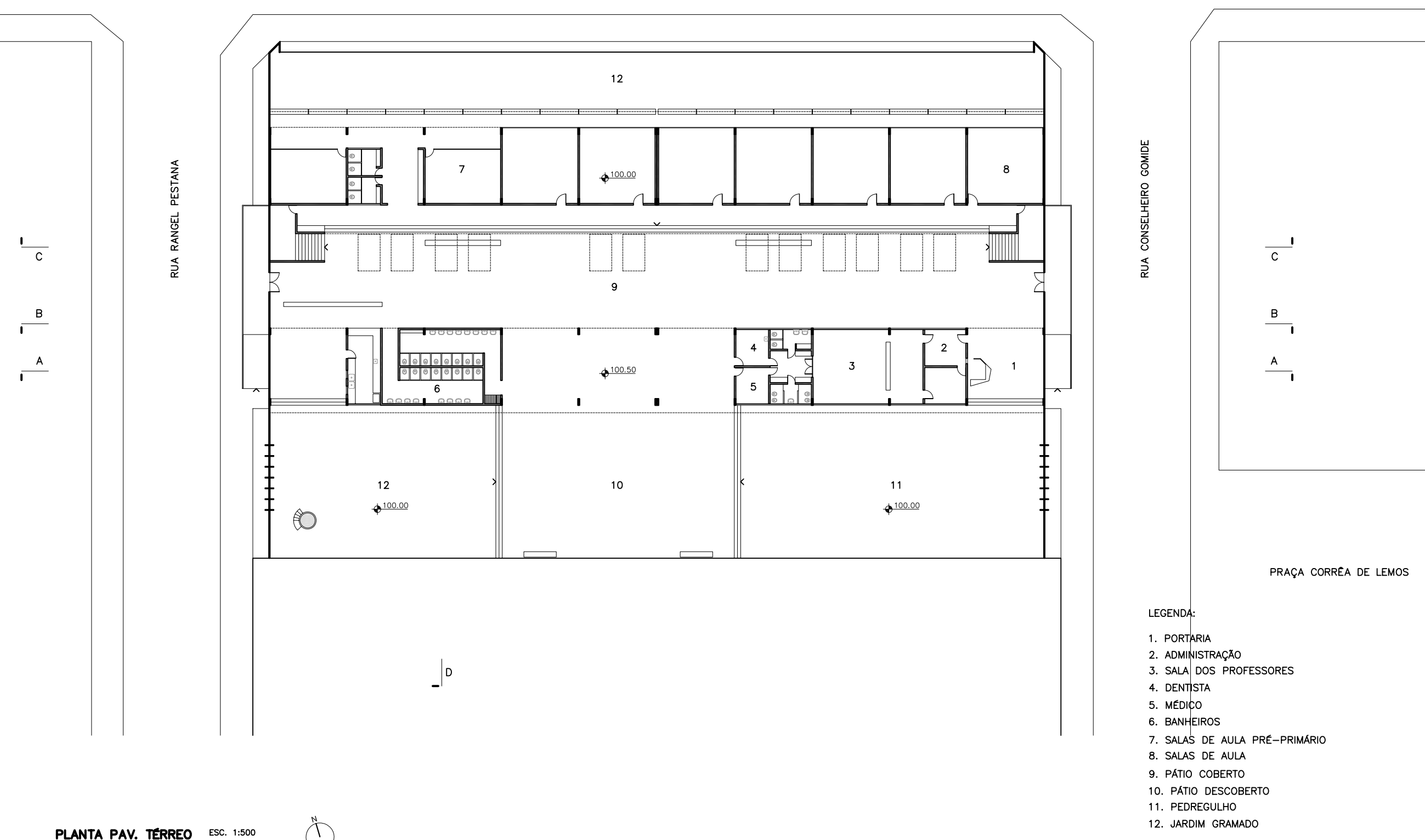


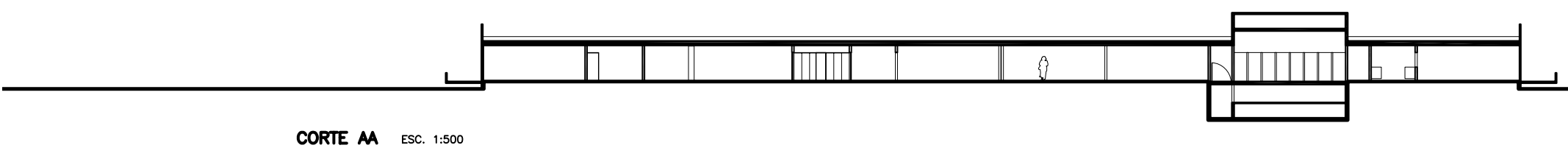

CORTE AM ESC. 1:500

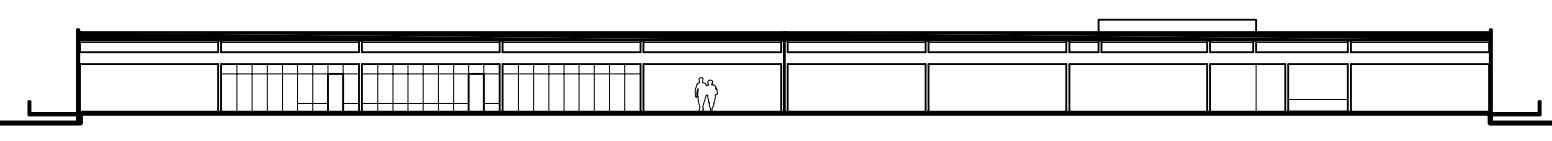

CORTE BB ESC. 1:500

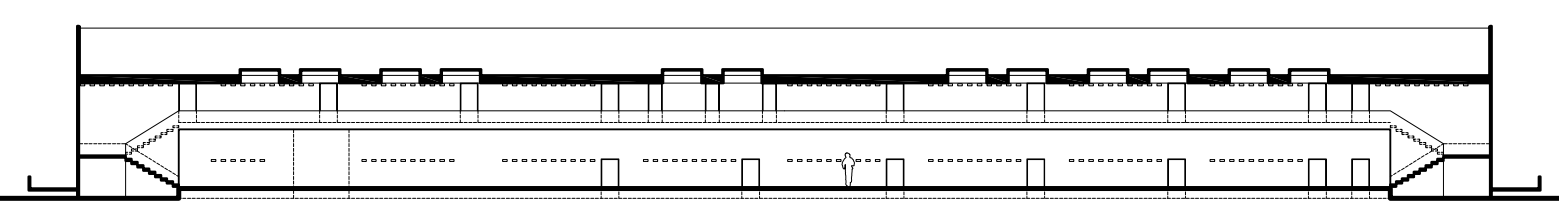

CORTE CC ESC. 1:500 


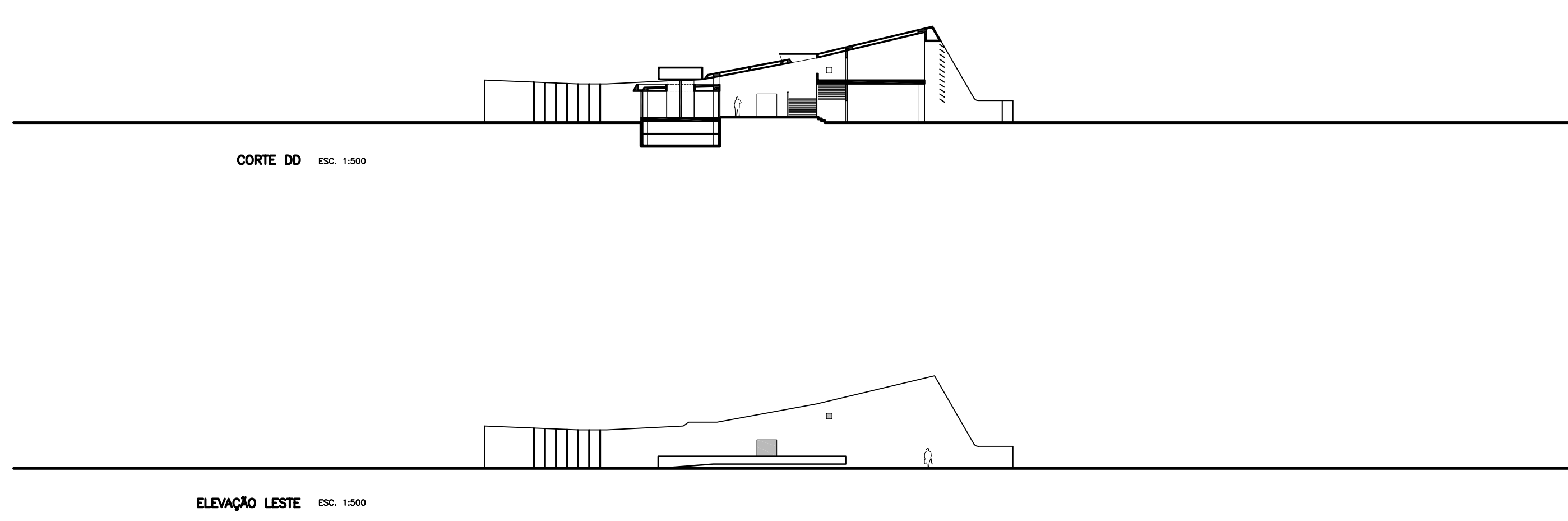




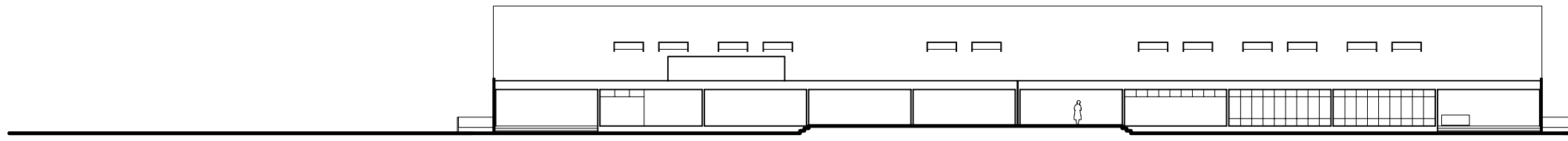

ELEVACAO SUL ESC. 1:500

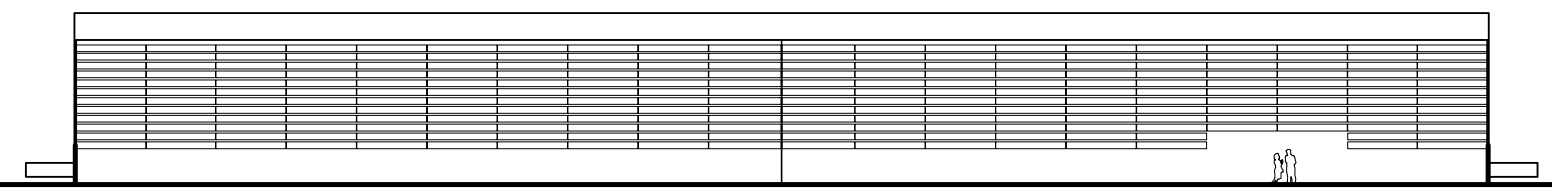

ELEVACAO NORTE ESC. 1:500 

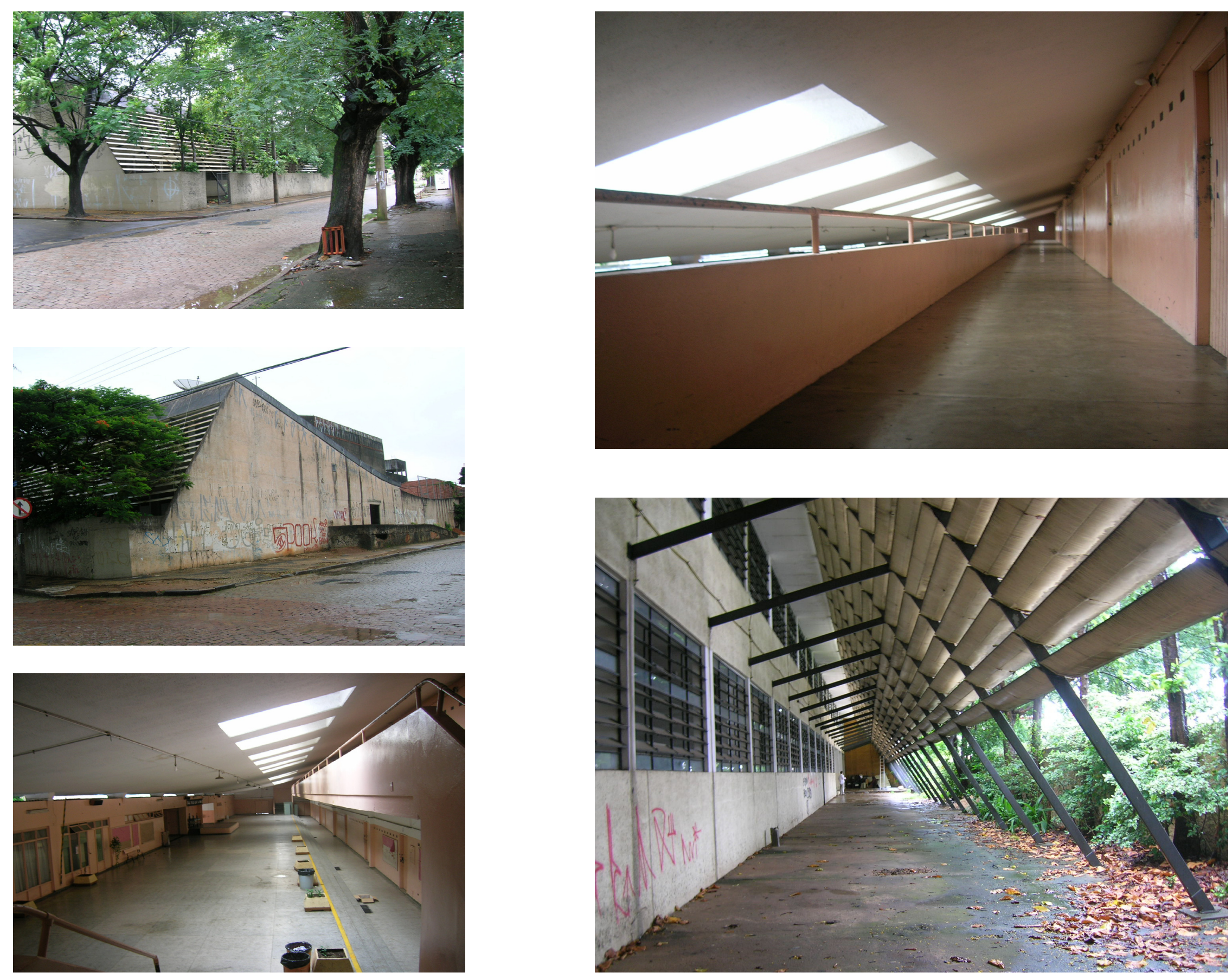


\section{EE Profa. Suely Antunes de Mello / 1961}

Rua Siqueira Campos, 845. Vila Maria. São José dos Campos, SP

Arquitetos: Paulo Mendes da Rocha e João Eduardo de Gennaro

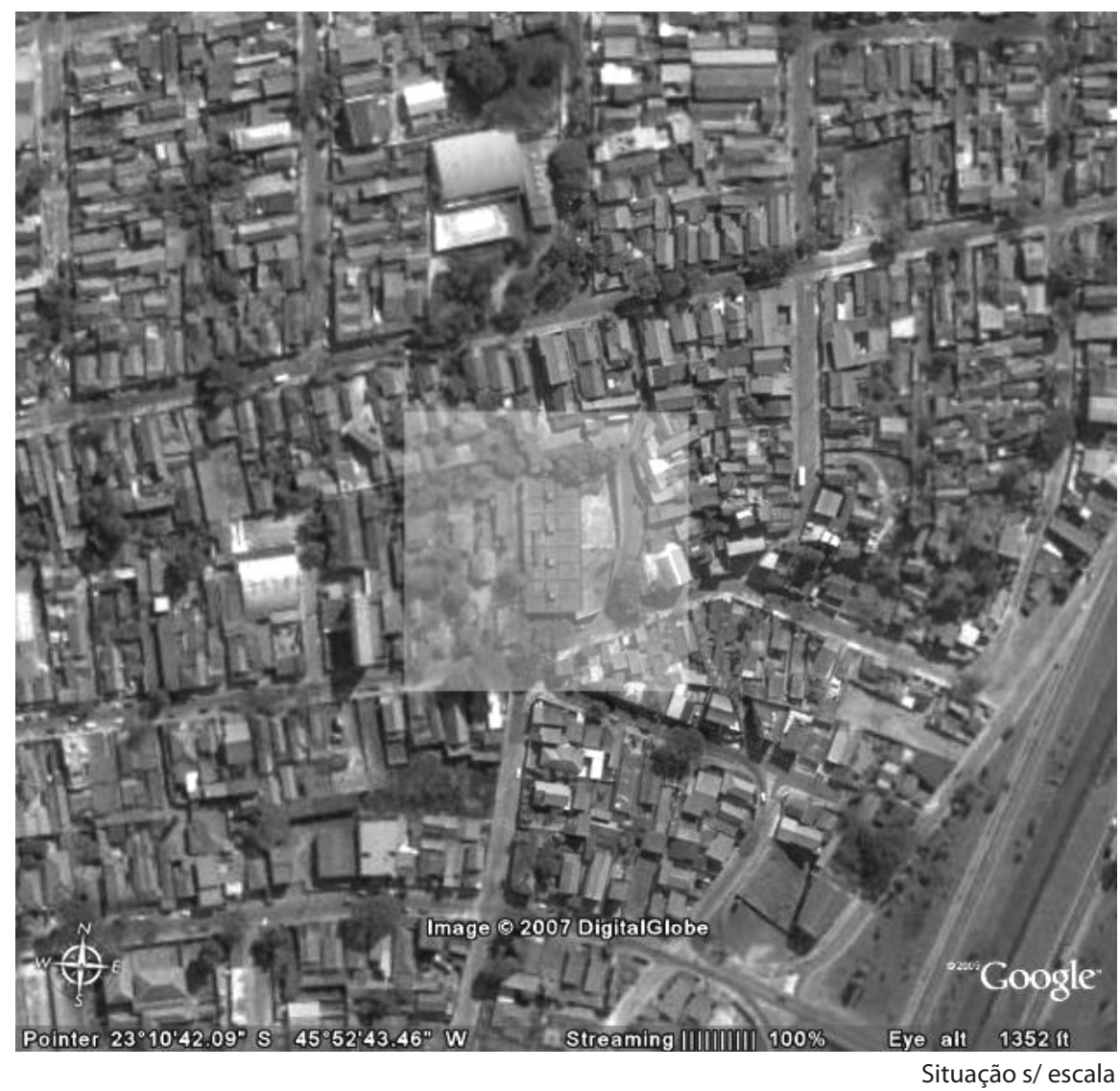



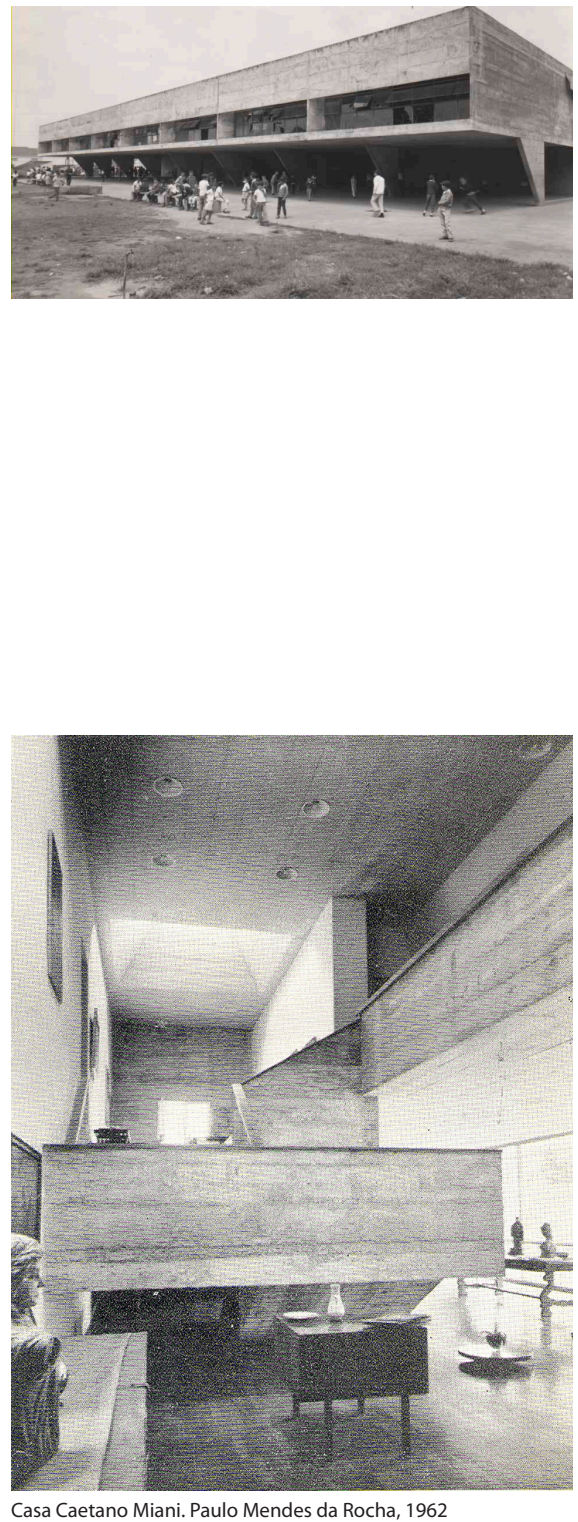

Escola primária projetada para o Governo do Estado de São Paulo através do IPESP. Localiza-se em São José dos Campos, em área de concentração industrial. Pensada como um prisma retangular, confeccionado em concreto armado aparente, pousa na paisagem acidentada do lugar apoiada em uma sucessão de pilares em forma de mãos francesas recuadas do alinhamento frontal do edifício, que estruturalmente funcionam como pórticos.

Organiza-se em dois pavimentos: o primeiro, acessado por uma viela junto a um muro de divisa previamente existente, abriga as dependências administrativas, bem como as salas de aula do pré-primário e seu pátio de recreio coberto. Um vazio de seis metros separa essa ala das oito salas de aula do primário, que estão debruçadas sobre a paisagem do vale. Esse vazio é iluminado através de quatro clarabóias generosas, o que confere a ele uma qualidade insuspeita. Uma ponte interliga, no eixo do vestíbulo de acesso, um lado ao outro. Nela localizase o volume dos banheiros dos "pequenos". Da ponte, uma grande escada em dois lances vincula os dois pavimentos.

O pavimento inferior concentra, junto ao arrimo de um pé-direito de altura, as dependências de serviço: banheiros nas extremidades, um palco, cozinha e refeitório. O pátio de recreação coberto tem comunicação desimpedida com o pátio externo, os jardins e a paisagem ao redor. Parte desse pátio tem dupla altura propiciada pelo intervalo entre alas e a luz das aberturas zenitais tocam o chão do recreio, mudando de foco e de intensidade com a oscilação do sol. Um pequeno auditório aberto foi desenhado praticamente no centro da edificação, através do desenho do chão: um ligeiro desnível de dez degraus sobre os quais são apoiados bancos corridos, com assentos pensados originalmente em madeira. A escada que liga os dois pavimentos debruça-se em seu patamar sobre a platéia, ampliando os recursos de utilização desse espaço. A ausência de barreiras entre interior e exterior no nível do pátio sugere uma escola aberta à comunidade, questão muito discutida pelos pensadores da educação no Brasil, principalmente aqueles ligados ao Movimento da Escola Nova, do qual, como já se disse, faziam parte, entre outros, os educadores Fernando de Azevedo e Anísio Teixeira.

Podemos destacar ainda que essa maneira de pensar o espaço edificado estava sendo aplicado em obras de funções distintas, o que valeu um memorável artigo escrito sobre Paulo Mendes da Rocha por Flávio Motta no qual o crítico discorre sobre o "espaço sem nome" nas obras do arquiteto. Vale lembrar a esse respeito a similaridade entre essa escola e a casa de Caetano Miani, na Granja Julieta em São Paulo, projetada pouco tempo depois, em 


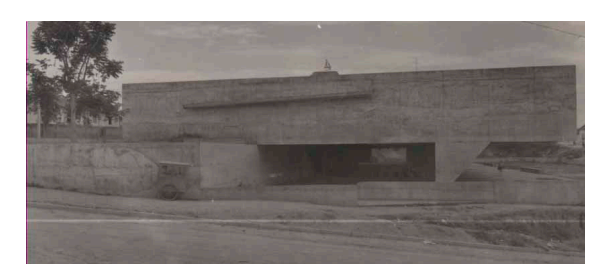

1962. Nela um vazio central separa o bloco de serviço do bloco dos dormitórios; sob eles a grande sala, aberta ao espaço externo. A cobertura com domus de iluminação e ventilação zenital é outro ponto de contato entre as obras, bem como a escada articuladora das funções nos edifícios. A galeria de circulação dos quartos assemelhase à das salas de aula, remetendo uma obra a outra. Por fim, a respeito da gênese da criação em arquitetura, Paulo Mendes da Rocha afirma que "Arquitetura é sempre um discurso entre aquilo que queremos ser e aquilo que já fizemos."2
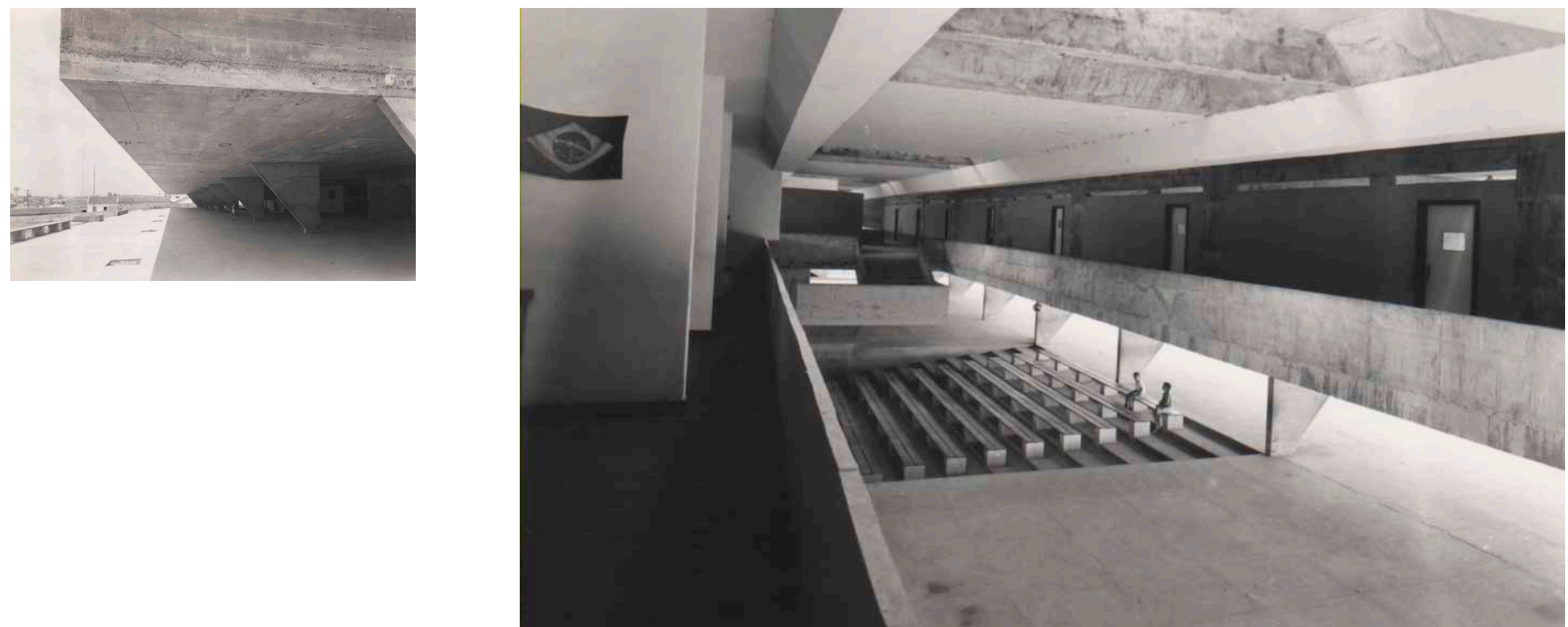


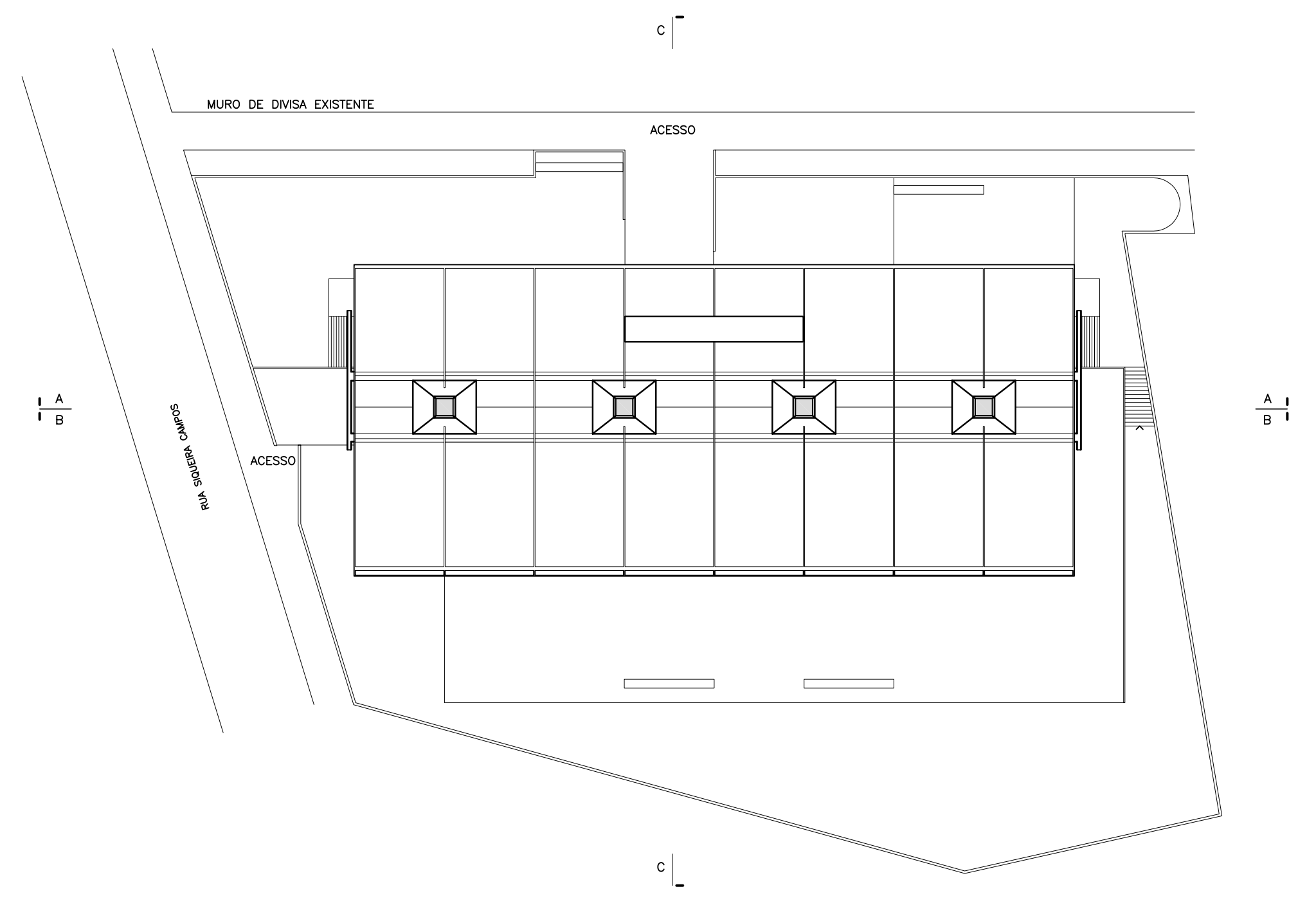

PLANTA DE COBERTURA ESC. 1:500 


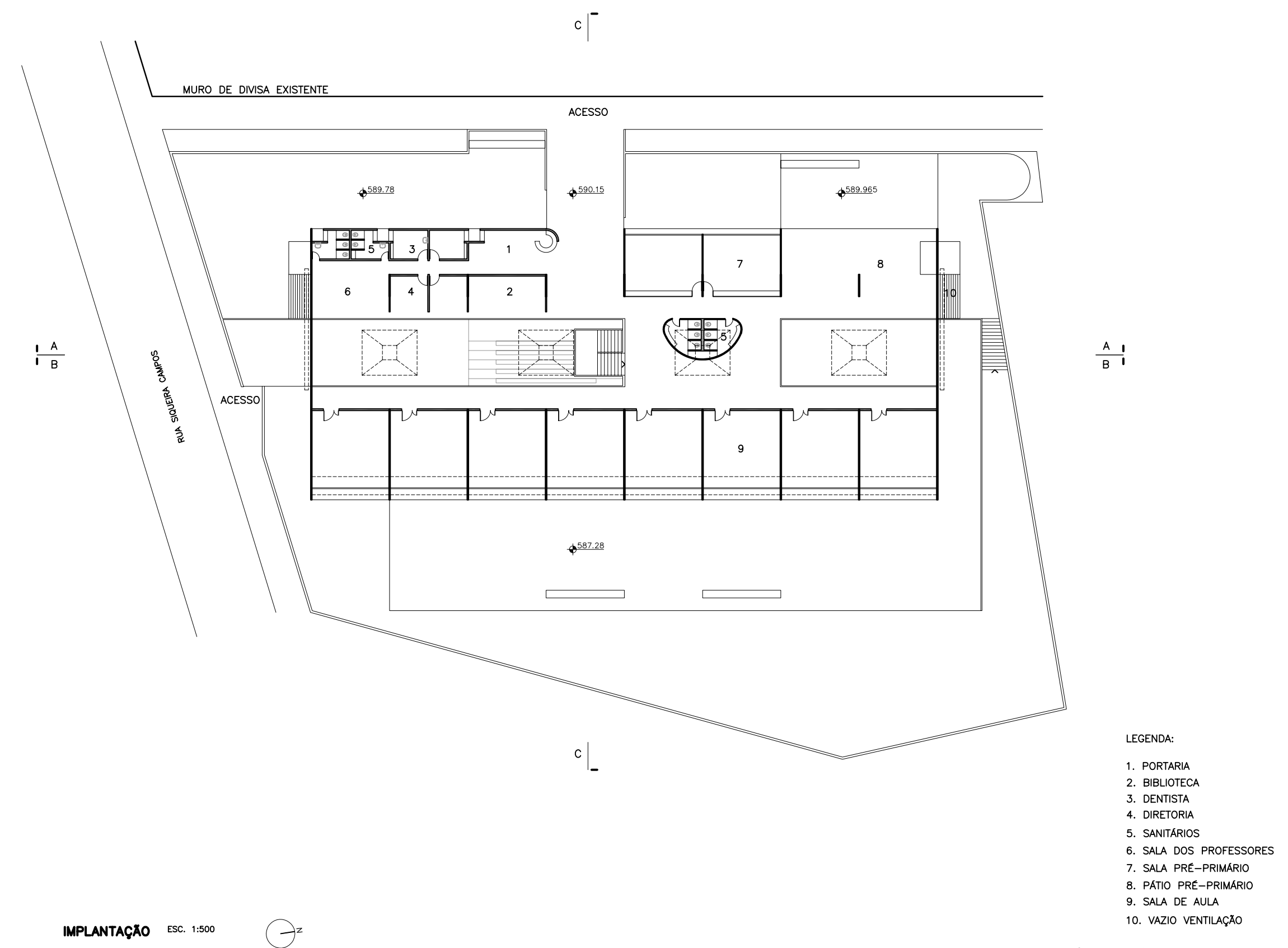

ESCOLAS PÚBLICAS EM SÃo PAULO (1960-1972) 


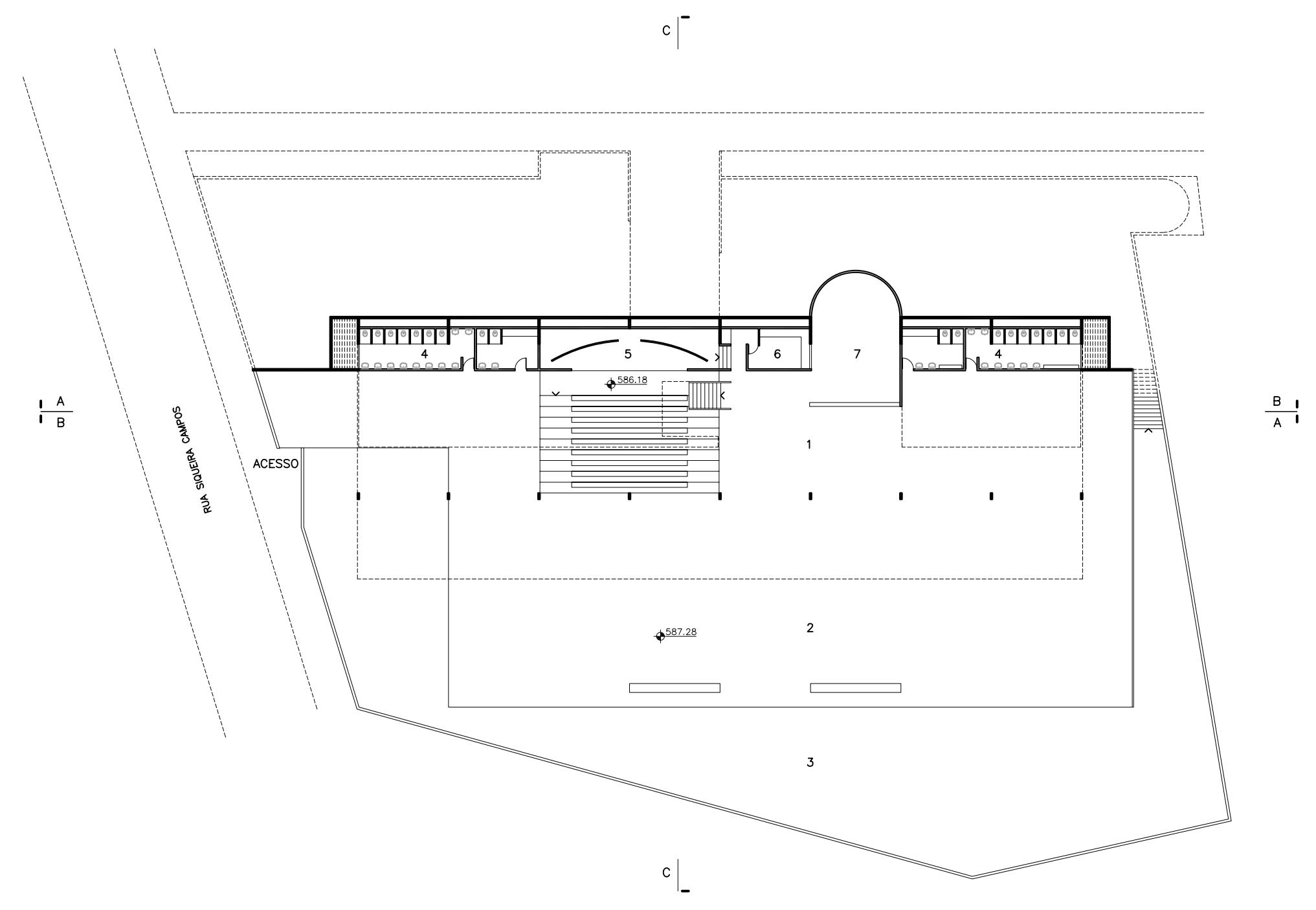

PLANTA PAV. INFERIOR ESC. 1:500

LEGENDA:

1. PATIO COBERTO

2. PATIO DESCOBERTO

3. JARDIM

4. BANHEIROS

5. PALCO

6. COZINHA

7. REFEITORIO 


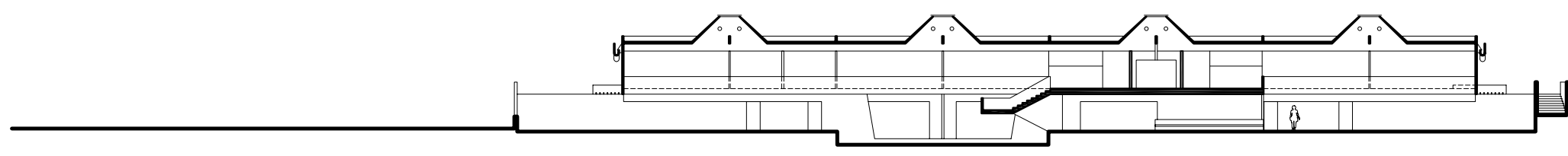

CORTE AA ESC. 1:500

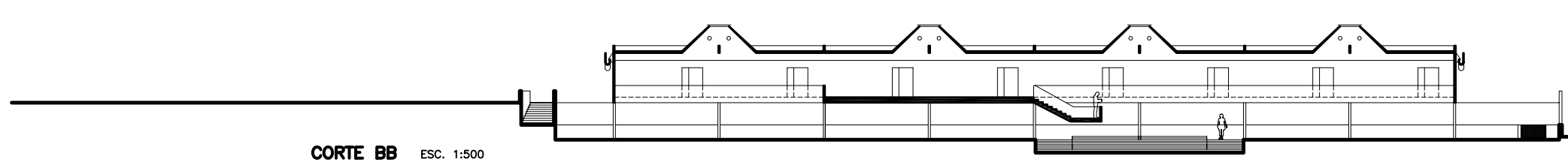




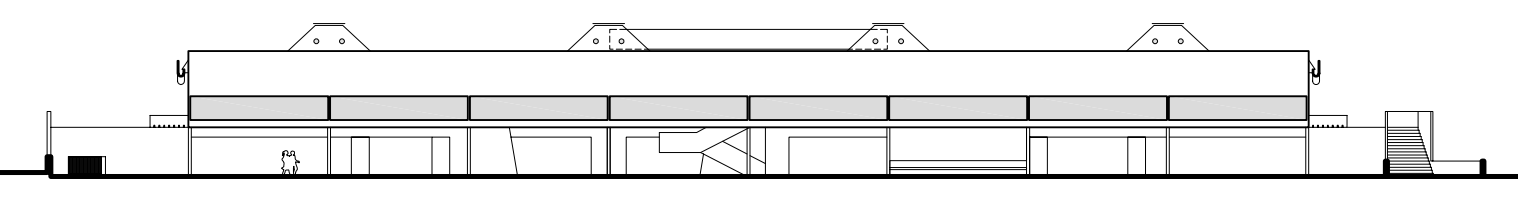

ELEVAÇAO LESTE ESC. 1:500

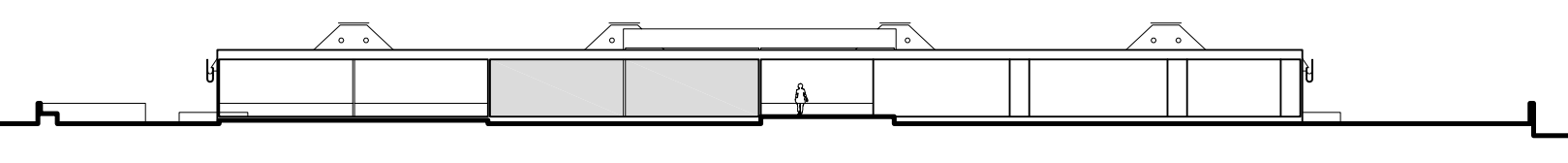

ELEVAGAO OESTE ESC. 1:500 


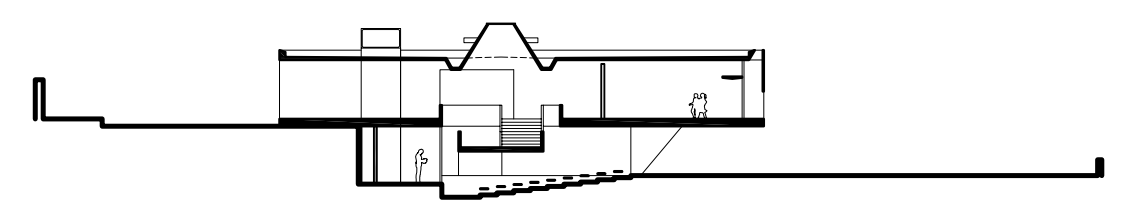

ELEVACAO SUL ESC. 1:500

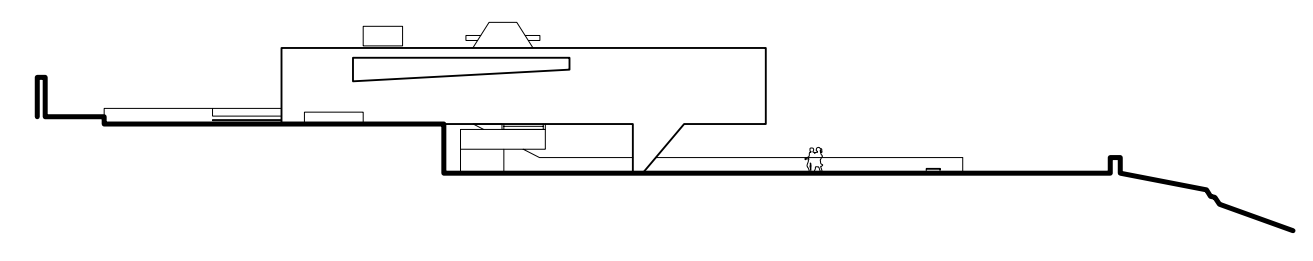

ELEVAÇAO NORTE ESC. 1:500

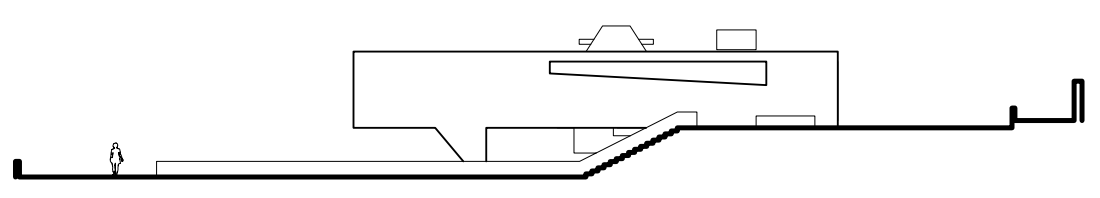



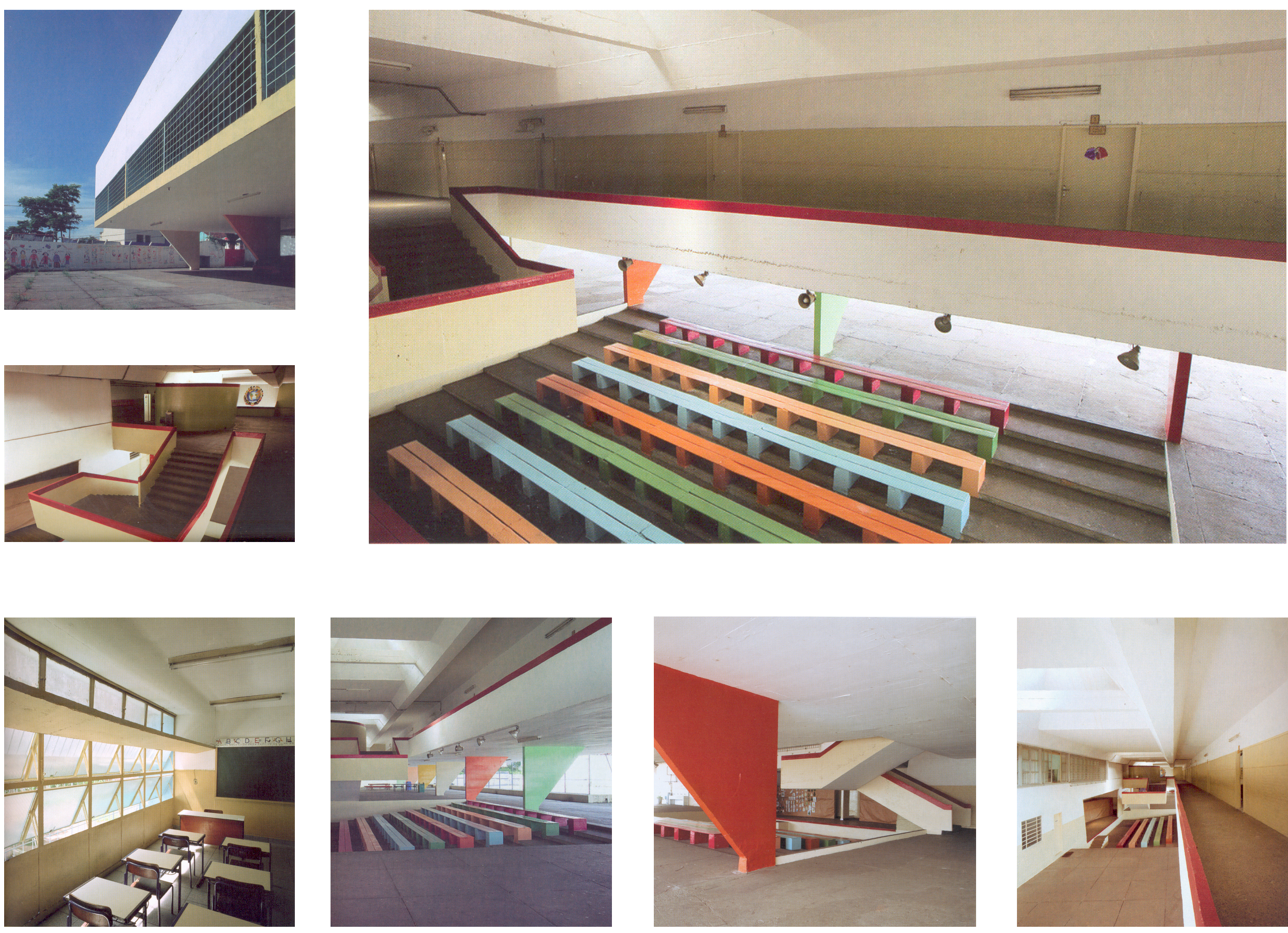


\section{EMEF Prof. Ramiro Gonzales Fernandes / 1962}

Rua Nigéria, 80, Taboão. São Bernardo do Campo, SP

Arquitetos: Paulo Mendes da Rocha e João Eduardo de Gennaro

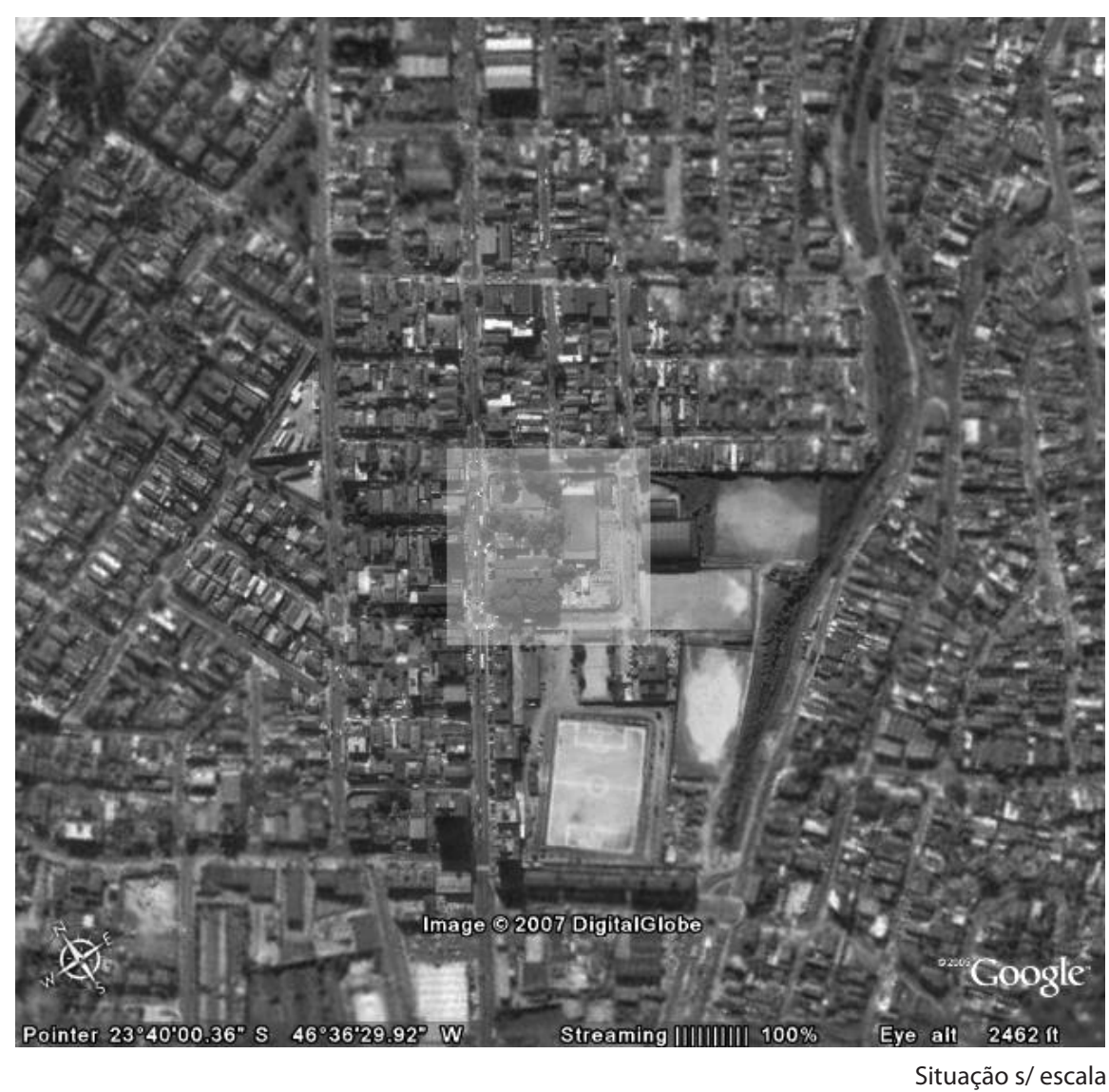



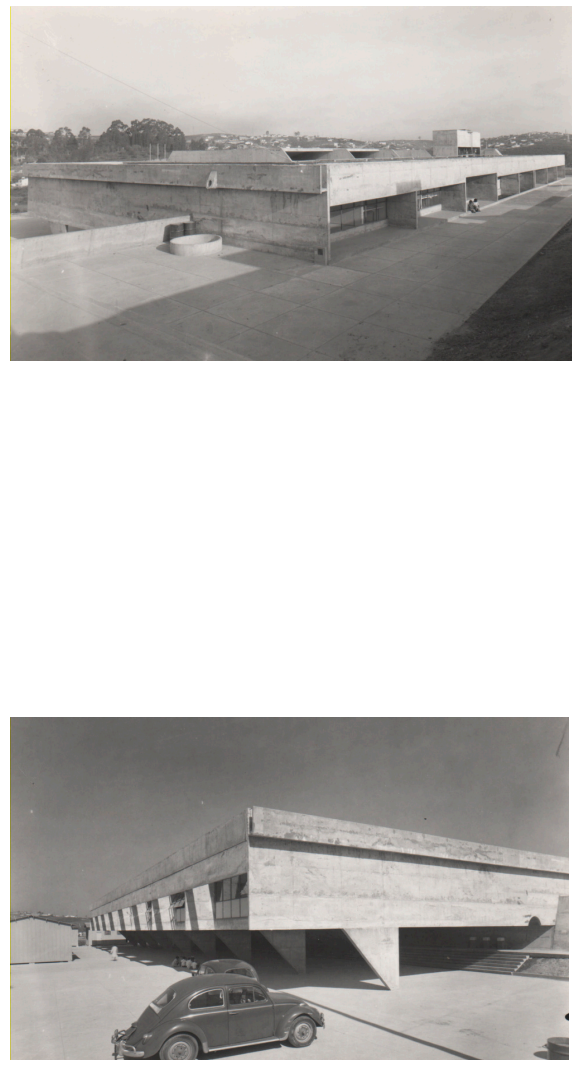

Durante a década de 1960 e início da década de 1970, um grande número de arquitetos e escritórios de arquitetura foram convocados a pensar os equipamentos públicos em São Bernardo do Campo, cidade que se consolidava como pólo industrial de São Paulo. Destaca-se nesse momento a atuação do então Prefeito Lauro Gomes que, em 1961, instituiu uma equipe de profissionais, liderados pelo arquiteto e urbanista Flávio Villaça, destinada a montar o Plano Diretor do Município:

"Este grupo, do qual faziam parte o engenheiro Orid H. Gerbelli e o arquiteto Hector J. Arroyo, passou posteriormente a constituir-se em grupo permanente do planejamento integrando-se na Diretoria de Projetos e Planejamento dirigida pelo arquiteto Jorge Olavo dos Santos Bonfim... estabelecendo Planos de Ação a curto e médio prazo, que definiram e programaram

obras a fim de atingir metas orientadas a atender as reais necessidades da cidade no campo da saúde, educação, recreação, juntamente com as de infra-estrutura, tudo em harmonia com os planos a longo prazo..."

O arquiteto Paulo Mendes da Rocha projetou três escolas para o município nesse período. O Grupo Escolar do Taboão, como era então conhecida essa escola, foi a primeira delas. Projetada um ano depois que a de Vila Maria, ela é muito parecida com a anterior, inclusive do ponto de vista do lugar em que está implantada (terreno em desnível voltado para um vale). Ambas, fundidas à geografia, impõem-se na paisagem como equipamento urbano dominante. ROCHA (2000) destaca o papel fundador da geografia no processo de projeto:

"Para mim, a primeira e primordial arquitetura é a geografia. Antes de construir, o homem escolheu um lugar, onde antevê uma situação arquitetônica sobre o espaço... A idéia de projeção desse universo, das instalações humanas, implica na idéia de construção a partir da configuração inicial que está na geografia e sua necessária transformação.”2

A estrutura da EMEF Prof. Ramiro G. Fernandes caracteriza-se também por uma sucessão de nove pórticos estruturais, cujo vão é definido pela largura das salas (oito ao todo). Os pilares de apoio assemelham-se aos da escola de Vila Maria, em forma de mãos francesas recuadas do plano das salas de aula, o que confere leveza ao corpo do edifício, pois os pilares ficam ocultos na sombra. Junto ao acesso principal estão localizados administração, duas salas de aula do pré-primário e seu respectivo pátio coberto, todos eles abertos para a face noroeste. Diferentemente da escola anterior, os níveis das duas alas opostas separadas pelo vazio do pátio de

Acrópole no 365. São Paulo, p. 15, set. 1969.

ROCHA, Paulo Mendes da. A cidade para todos. In: ARTIGAS, Rosa (org.). Paulo Mendes da Rocha. São Paulo: Cosac \& Naify; Associação Brasil 500 Anos Artes Visuais; Fundação Bienal de São Paulo, 2000, p. 172. 
recreio estão desnivelados em $60 \mathrm{~cm}$, o que constitui um pé-direito maior nas oito salas voltadas ao vale (face sudeste). Outra característica que difere as duas escolas é o fato dessa incorporar ao pátio do pré-primário os banheiros e posicionar, no centro do vazio, a biblioteca e a sala dos professores.

O pavimento inferior abriga, junto ao arrimo, cozinha, refeitório e banheiros na cota 99,00 e o pátio de recreação coberto, pouco mais de um metro abaixo desse nível (97.859), com extensão em nível ao pátio descoberto e aos jardins. Através de um outro patamar chega-se à rua principal de acesso para os alunos e para a comunidade.

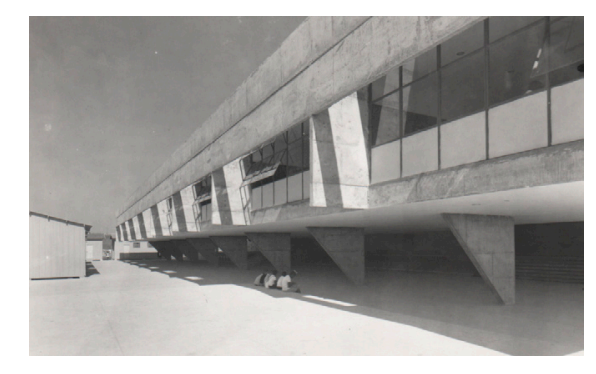

Outra característica dessa escola é a cobertura plana e impermeabilizada, que retoma um tipo de abertura zenital em forma de sheds (como na escola de Campinas) voltados ora para a face sudeste ora à noroeste, gerando uma alternância de incidência de luz no vazio da escola.

A construção é pensada de maneira sempre muito despojada: concreto armado aparente, com a marca das formas de madeira e seus veios; alvenarias de fechamento independentes da estrutura; aberturas generosas configuradas por caixilhos de ferro e vidro, além de captação e escoamento das águas pluviais através de calhas, gárgulas e "poços" de captação expostos. Tudo isso somado confere à obra um caráter modelar, paradigmático, como se assim pudessem ser todas as instalações humanas.

Embora a escola esteja num estado razoável de conservação, no que tange à sua estrutura e instalações, algumas alterações acabaram por descaracterizá-la. Uma delas foi a ocupação de parte do vazio com uma rampa que inviabilizou parte significativa do pátio, executada com o intuito de adaptar a escola a pessoas portadoras de necessidades especiais (o que é legítimo, desde que feito de maneira adequada). Outra alteração foi a construção de um bloco anexo de salas de aula e afins no pátio externo da escola, rompendo a continuidade espacial proposta. Po fim, outra mudança, essa mais urbana que arquitetônica (se é que pode-se distinguir uma da outra), foi a ocupação descriterioza da quadra em que a escola está instalada, o que ilustra de maneira bastante significativa o desmonte do Grupo de Planejamento acima mencionado. A quadra contempla, além dessa escola, uma outra, e também um posto de saúde, gerando espaços segregados e áreas residuais sem nenhum caráter. 


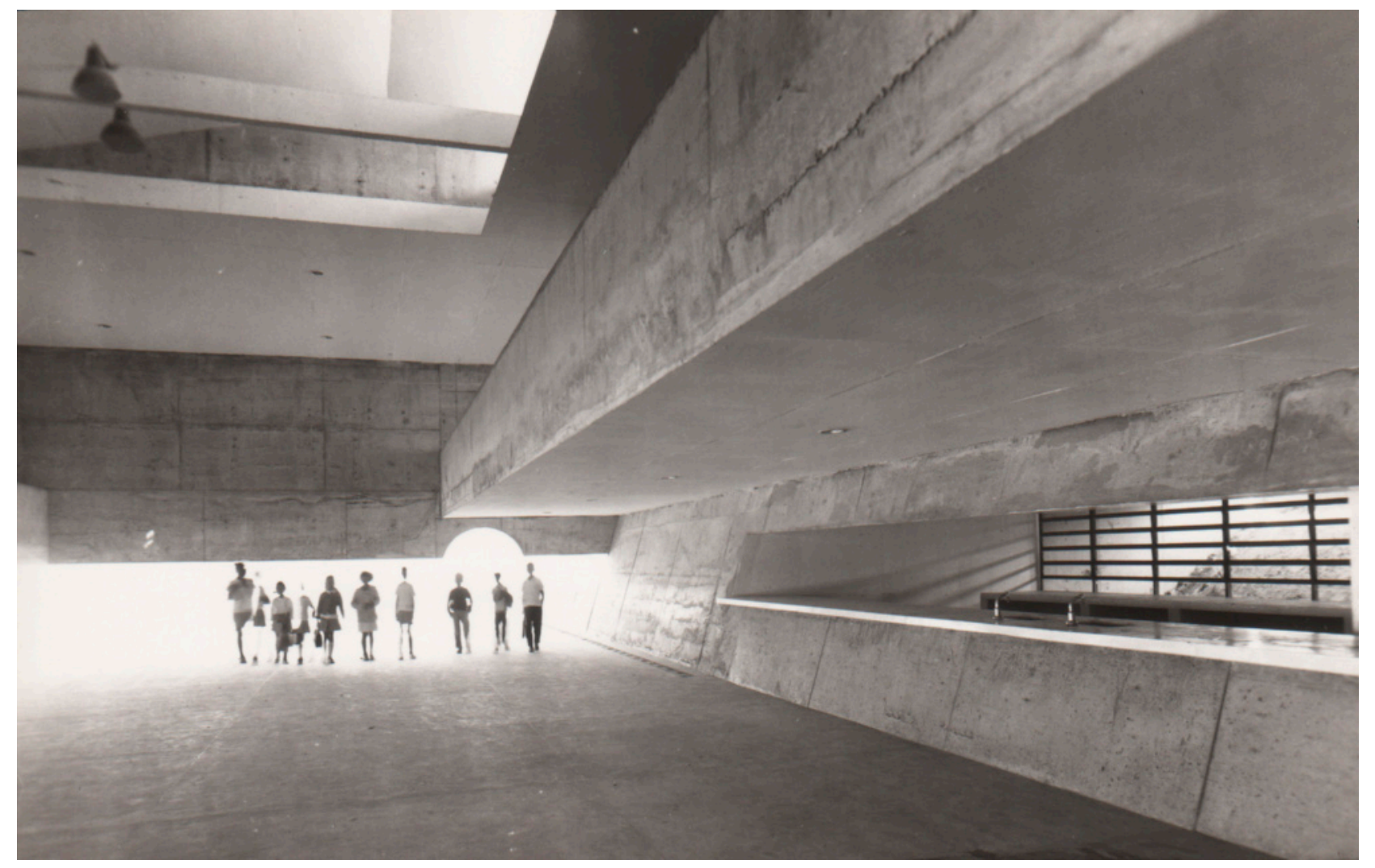




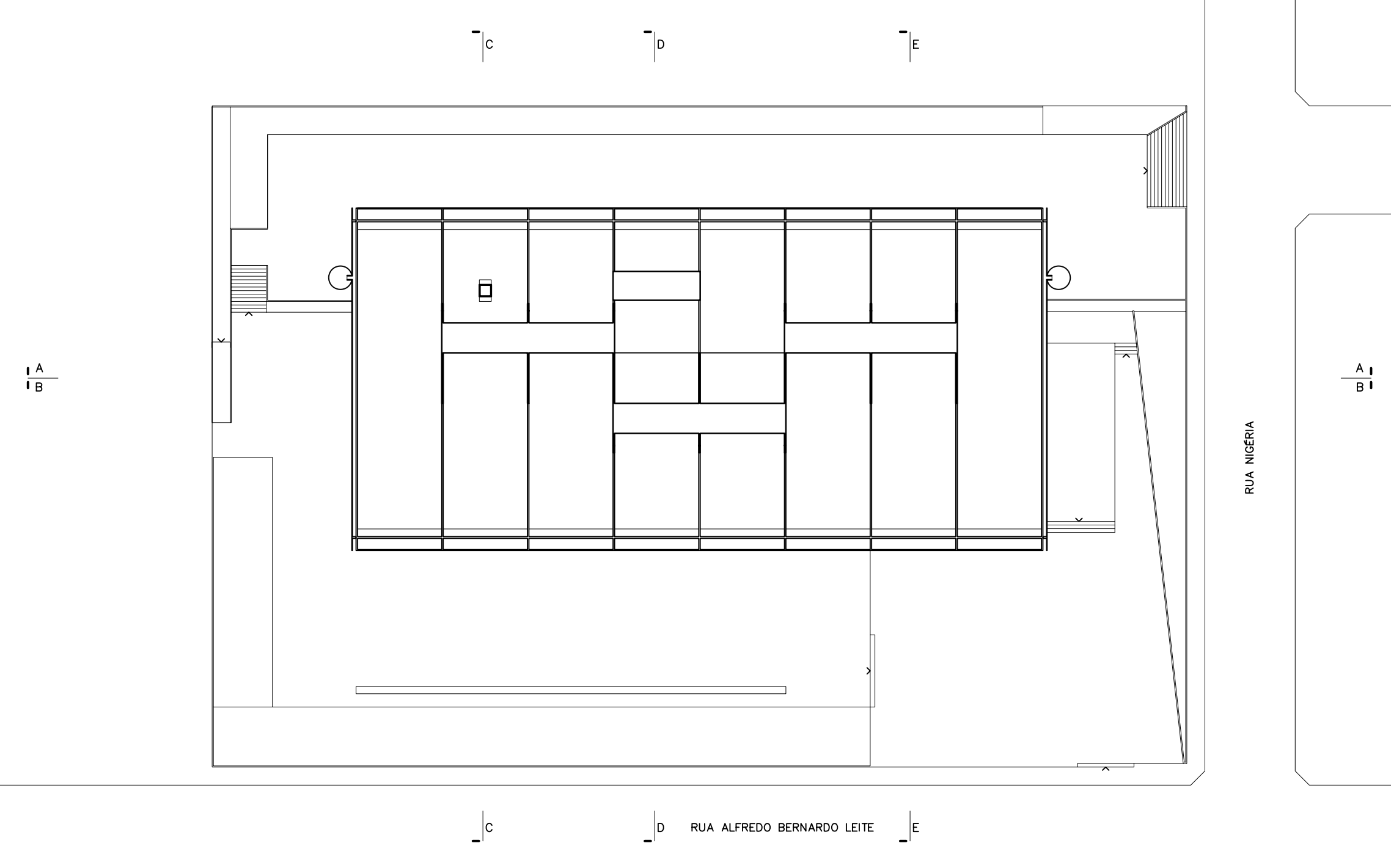



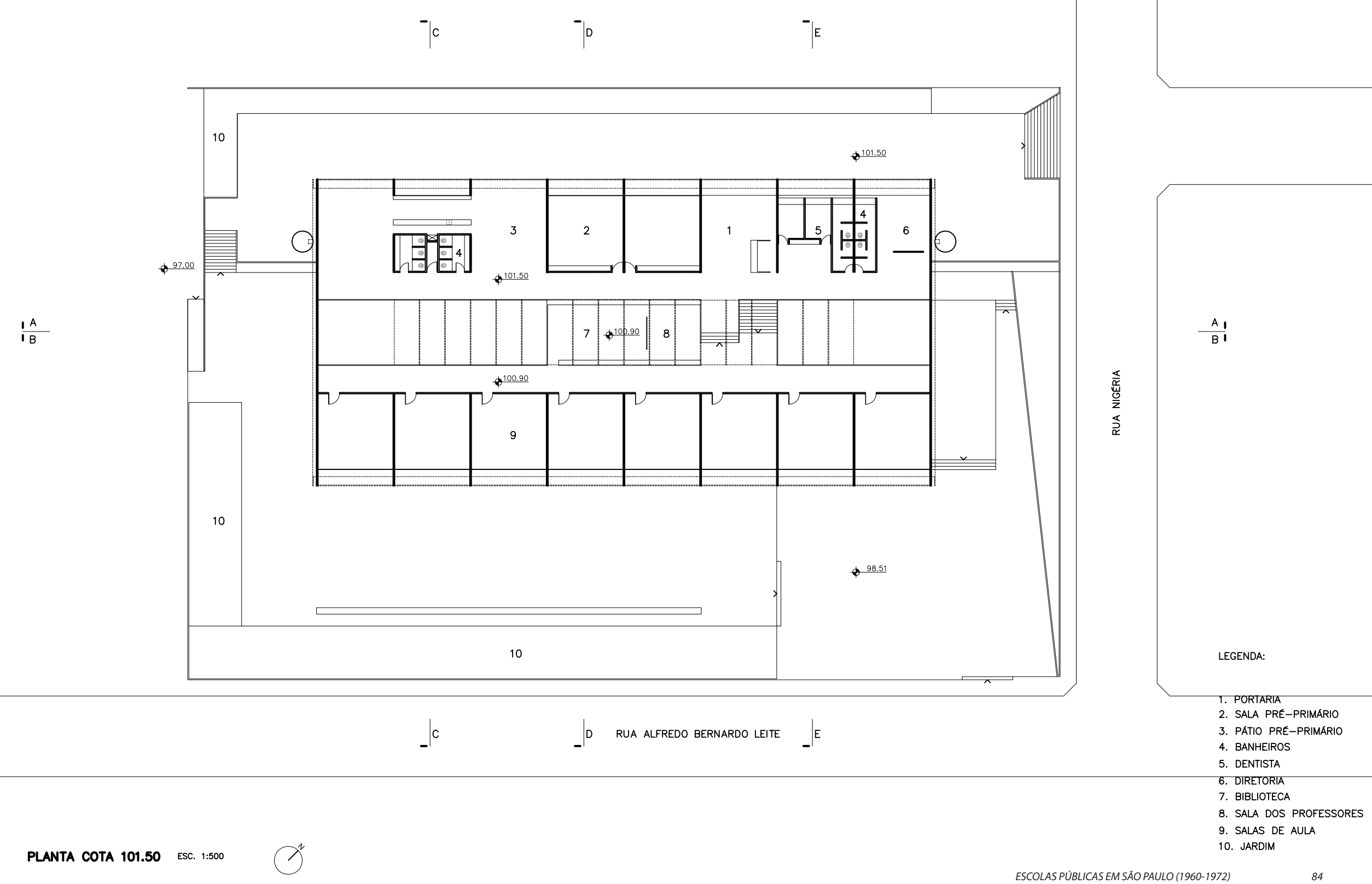

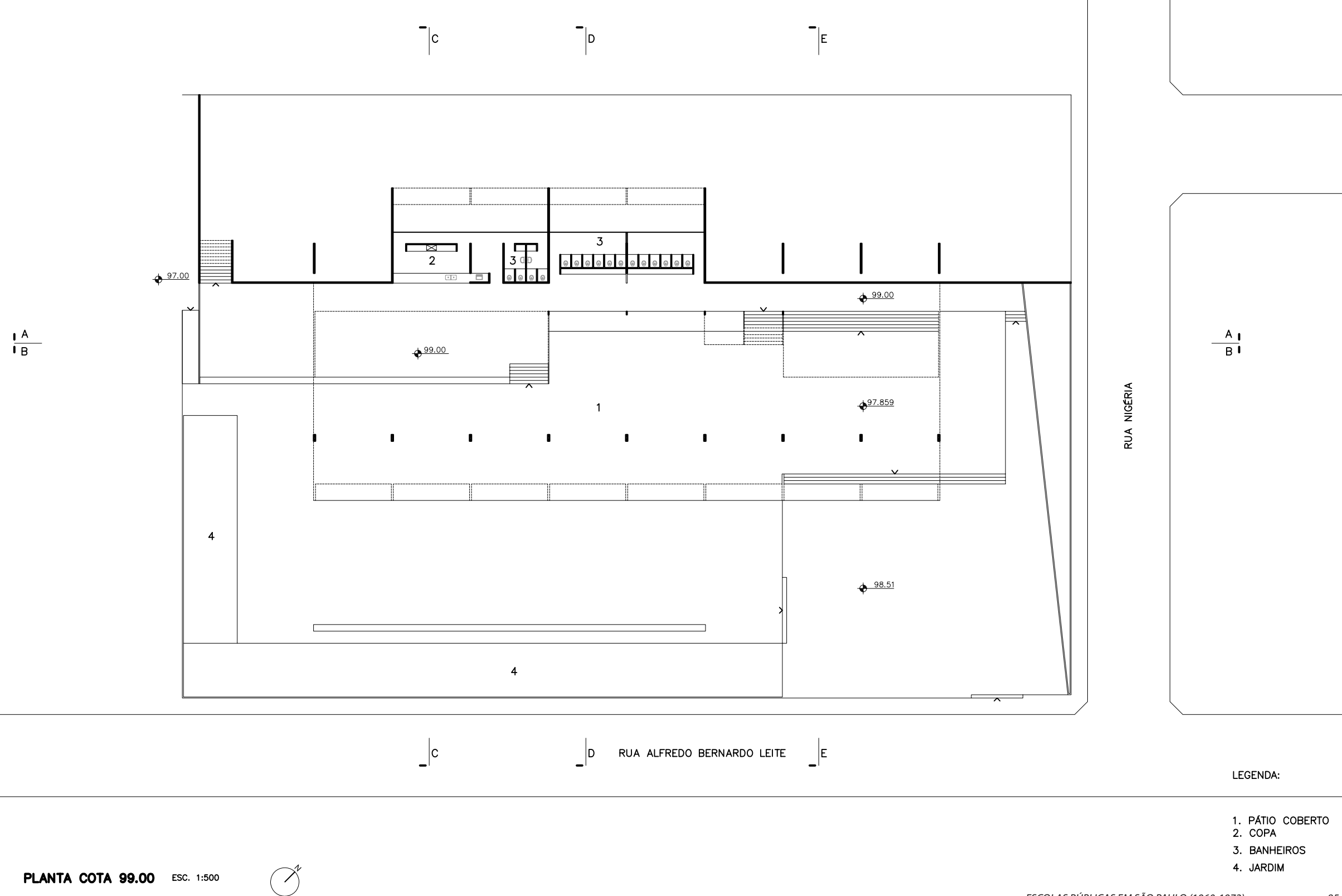


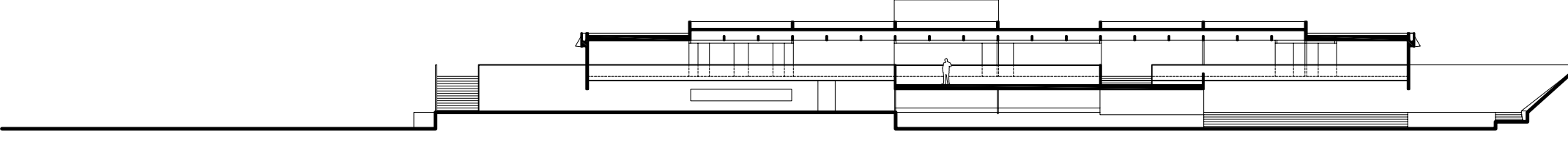

CORTE AM ESC. 1:500

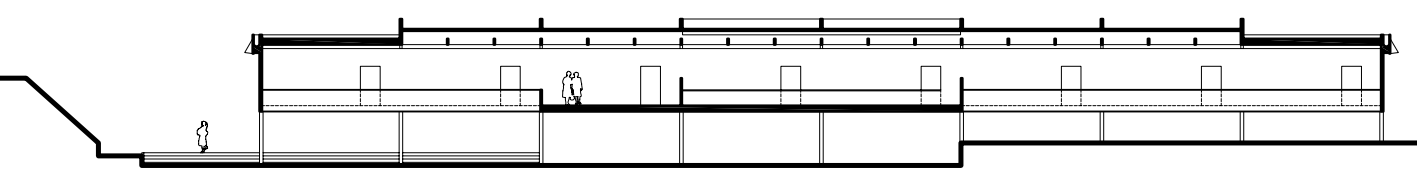

CORTE BB ESC. 1:500 


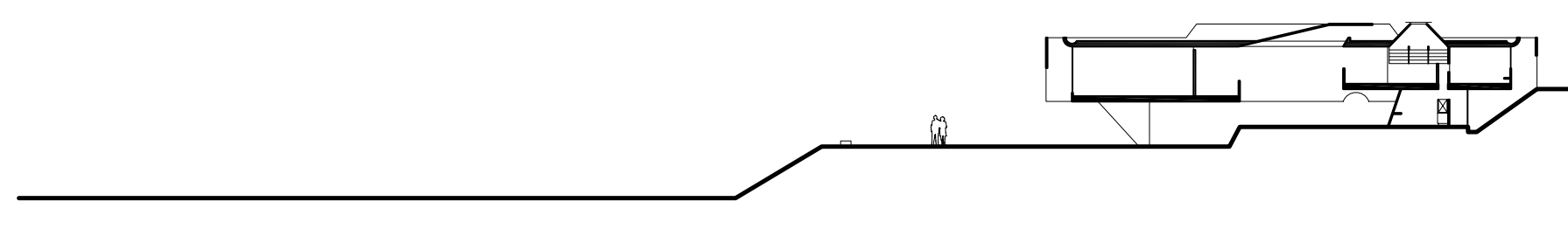

CORTE CC ESC. 1:500

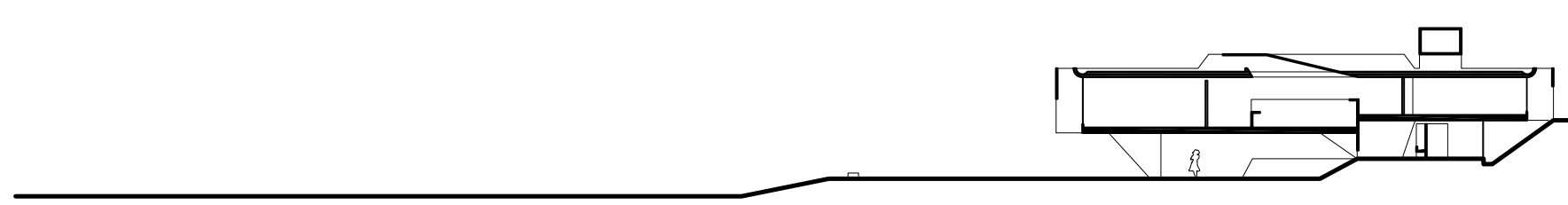

CORTE DD ESC. 1:500

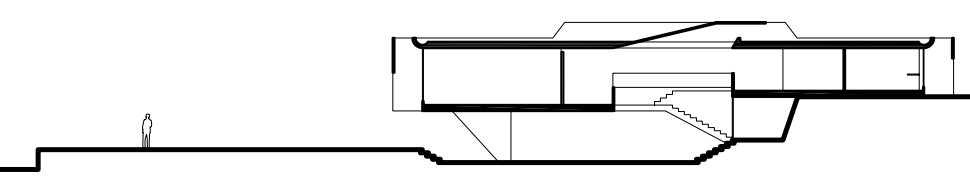

CORTE EE ESC. 1:500 


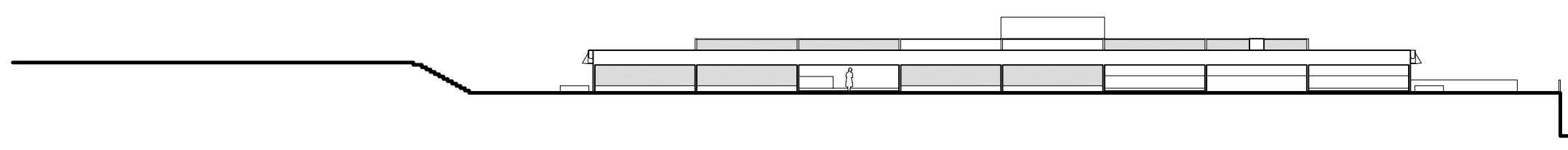

ELEVACAOA NORTE ESC. 1:500

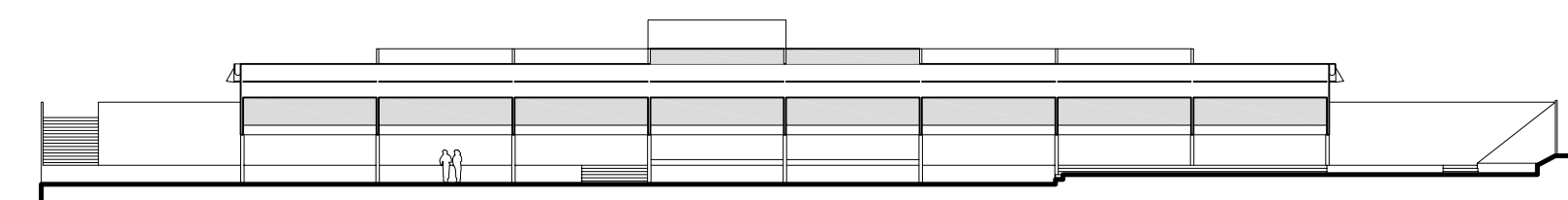

ELEVAGAO SUL ESC. 1:500 


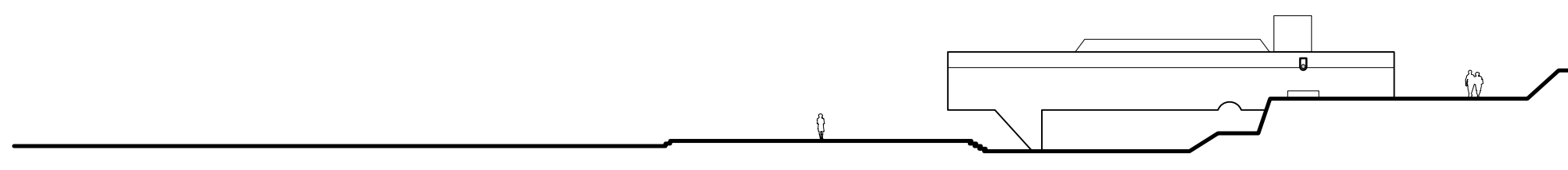

ELEVAÇAO LESTE ESC. 1:500

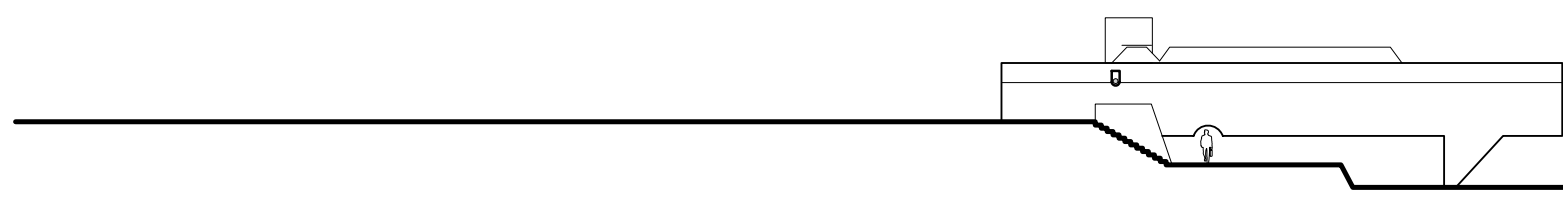

ELEVACAO OESTE ESC. 1:500 

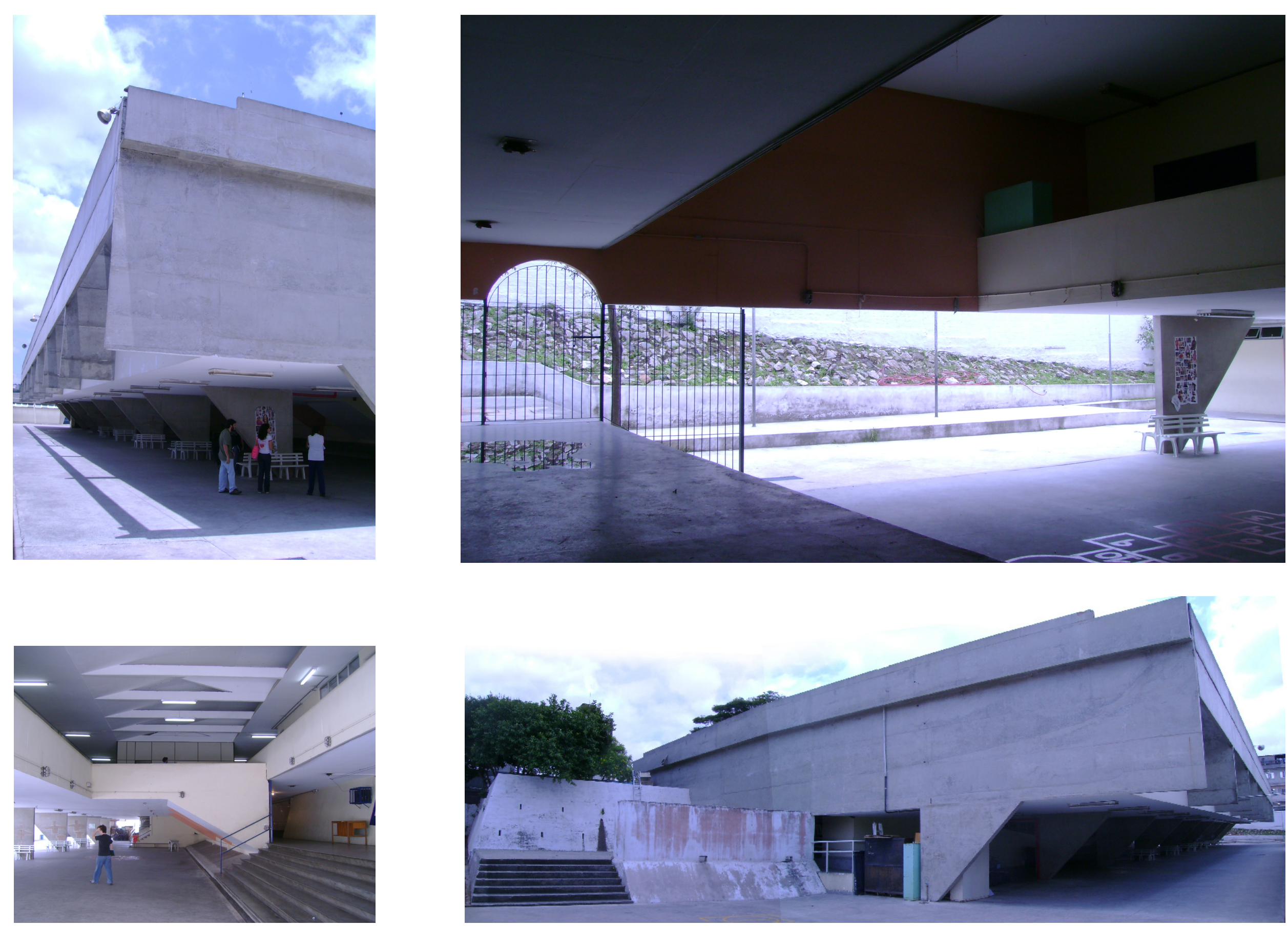


\section{EE Gofredo Teixeira da Silva Telles / 1967}

Rua Giacinto Tognato, Vila Baeta Neves. São Bernardo do Campo, SP

Arquitetos: Paulo Mendes da Rocha e Eduardo de Gennaro

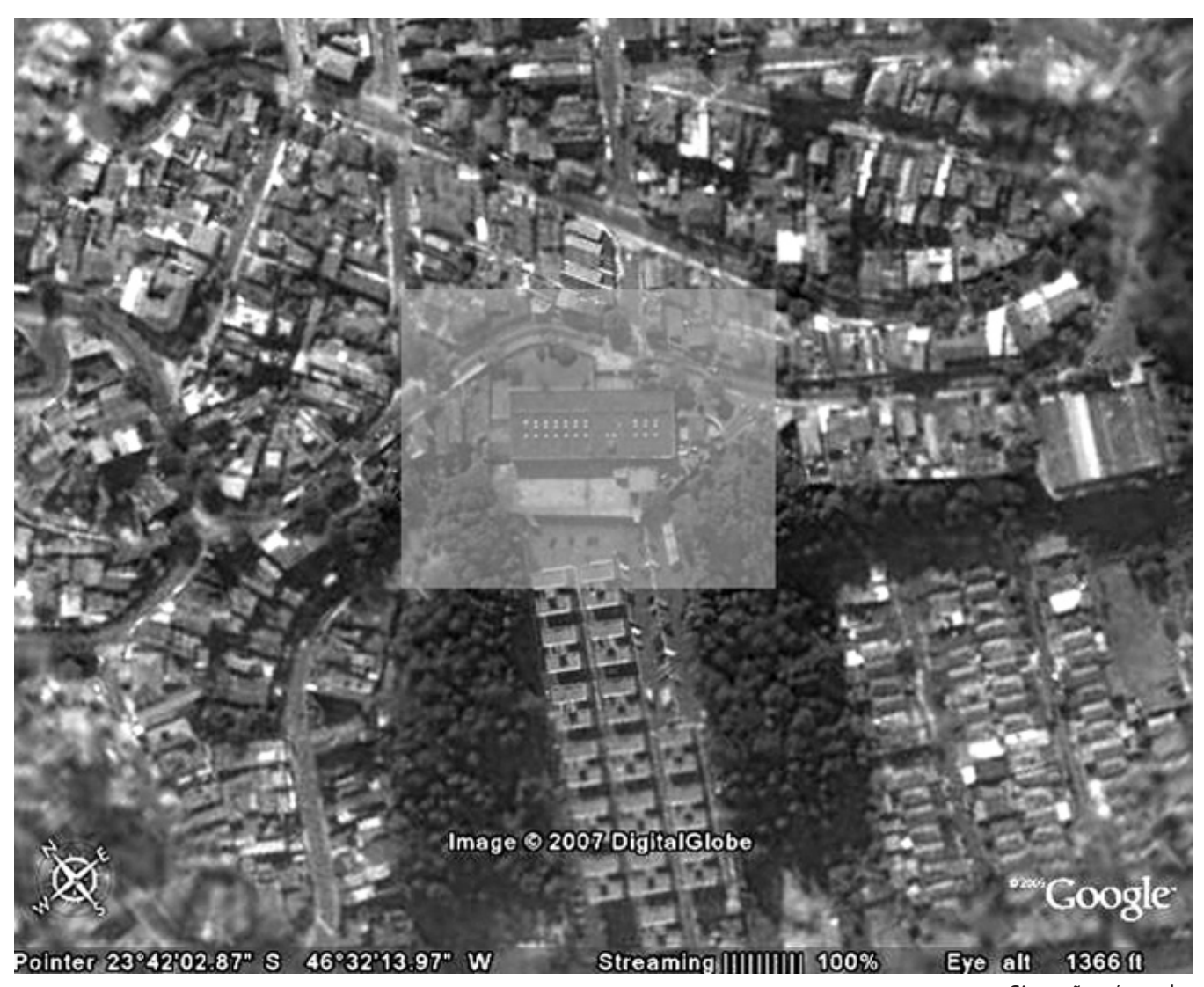

Situação s/ escala 

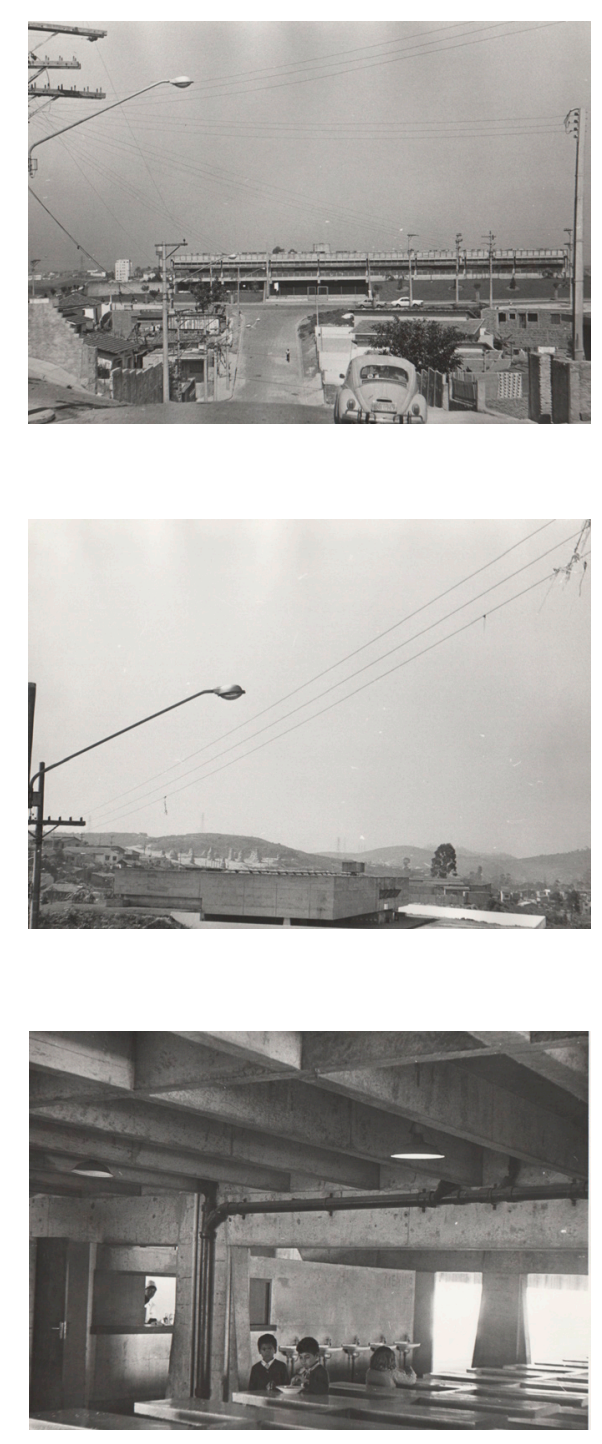

Segunda escola projetada pelo arquiteto para o município de São Bernardo do Campo, situa-se "no topo do morro do Piolho"1 em situação de destaque em relação ao entorno construído.

Escola primária com programa idêntico ao das duas escolas anteriores. Dez salas de aula (oito destinadas ao primário e duas, ao pré-primário), administração, serviços e um extenso pátio coberto por uma grande laje de concreto impermeabilizada iluminada zenitalmente.

Entra-se na escola por um "túnel" em nível com a rua Giacinto Tognato. O pátio de recreação coberto fica em nível com a calçada, separado dela por uma camada de terra a noroeste e as salas de pré-primário a sudeste. A escada de conexão entre os dois níveis serve de baliza entre exterior e interior. Na outra extremidade banheiros, cozinha e refeitório. No mesmo eixo de acesso, no pavimento superior, localiza-se o bloco administrativo e a biblioteca, localizada ao lado da escada, entre a administração e a galeria das salas de aula. Essas salas voltam-se para a rua num pavimento acima (face nordeste) e são protegidas da incidência direta da luz do sol por placas horizontais em concreto armado. Na extremidade oposta, um pano vertical de concreto armado chega quase até o chão, separado deste pela altura de uma porta $(2.10 \mathrm{~m})$. Essa massa pesada, banhada de luz internamente por um rasgo longitudinal na cobertura, parece querer destacar-se da estrutura porticada, como se flutuasse.

O desenho dos pilares, parecidos um pouco com os pilares do Ginásio de Guarulhos, denotam na geometria de sua forma, com suas angulações, a tentativa de anular as deformações provenientes da equação dos esforços verticais, do vão central e dos balanços laterais. Vale ressaltar, nas quatro escolas até aqui apresentadas, a unidade entre engenharia² e arquitetura, técnica e poesia, espaço e construção.
XAVIER, Alberto; LEMOS, Carlos; CORONA, Eduardo. Arquitetura Moderna Paulistana. São Paulo: Pini, 1983, p. 94.

$\mathrm{O}$ projeto de estrutura dessas quatro escolas foram realizados pelo engenheiro Siguer Mitsutani, parceiro de inúmeros projetos e obras realizados pelos arquitetos Paulo Mendes da Rocha e Eduardo de Gennaro. 

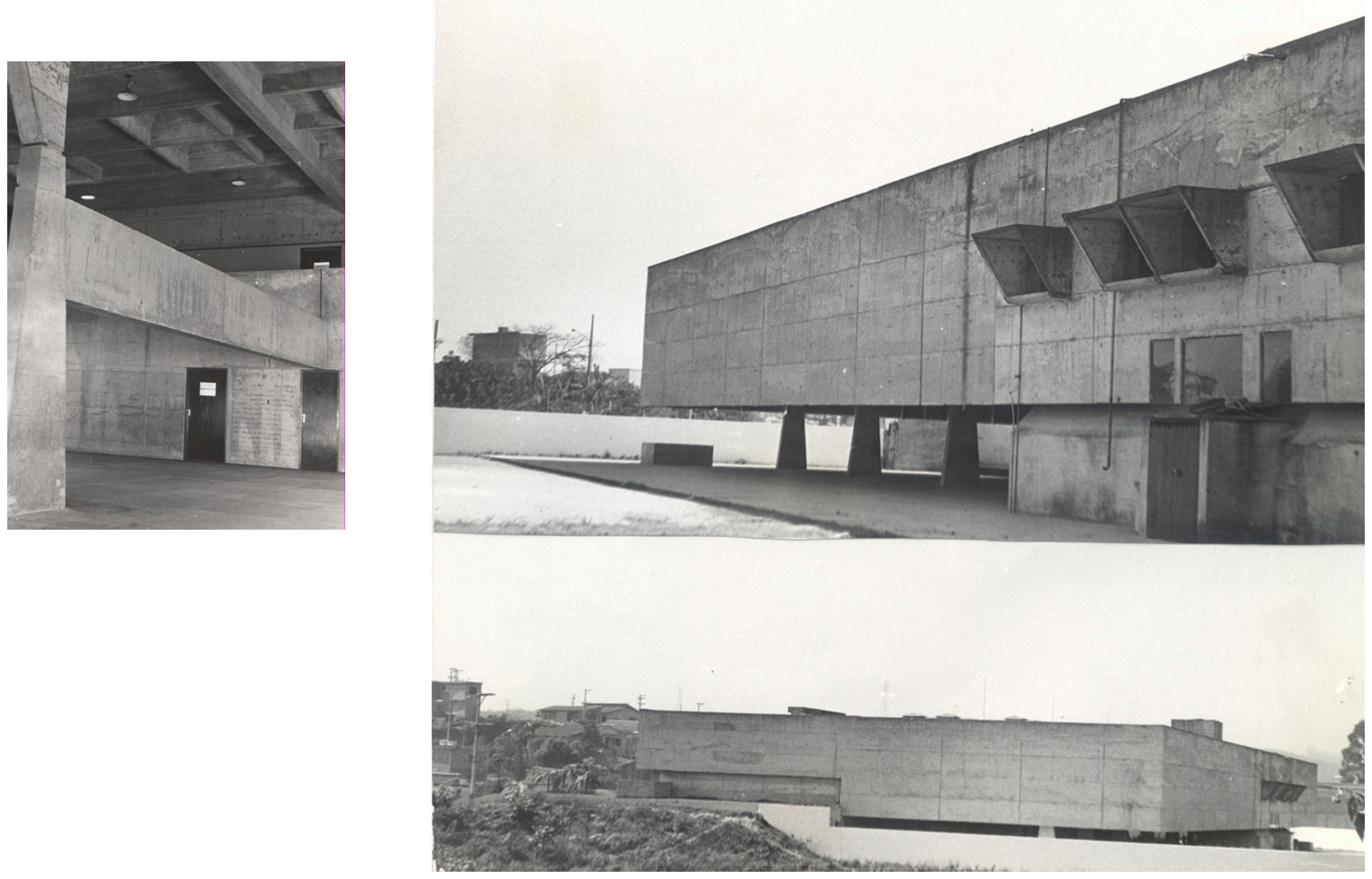


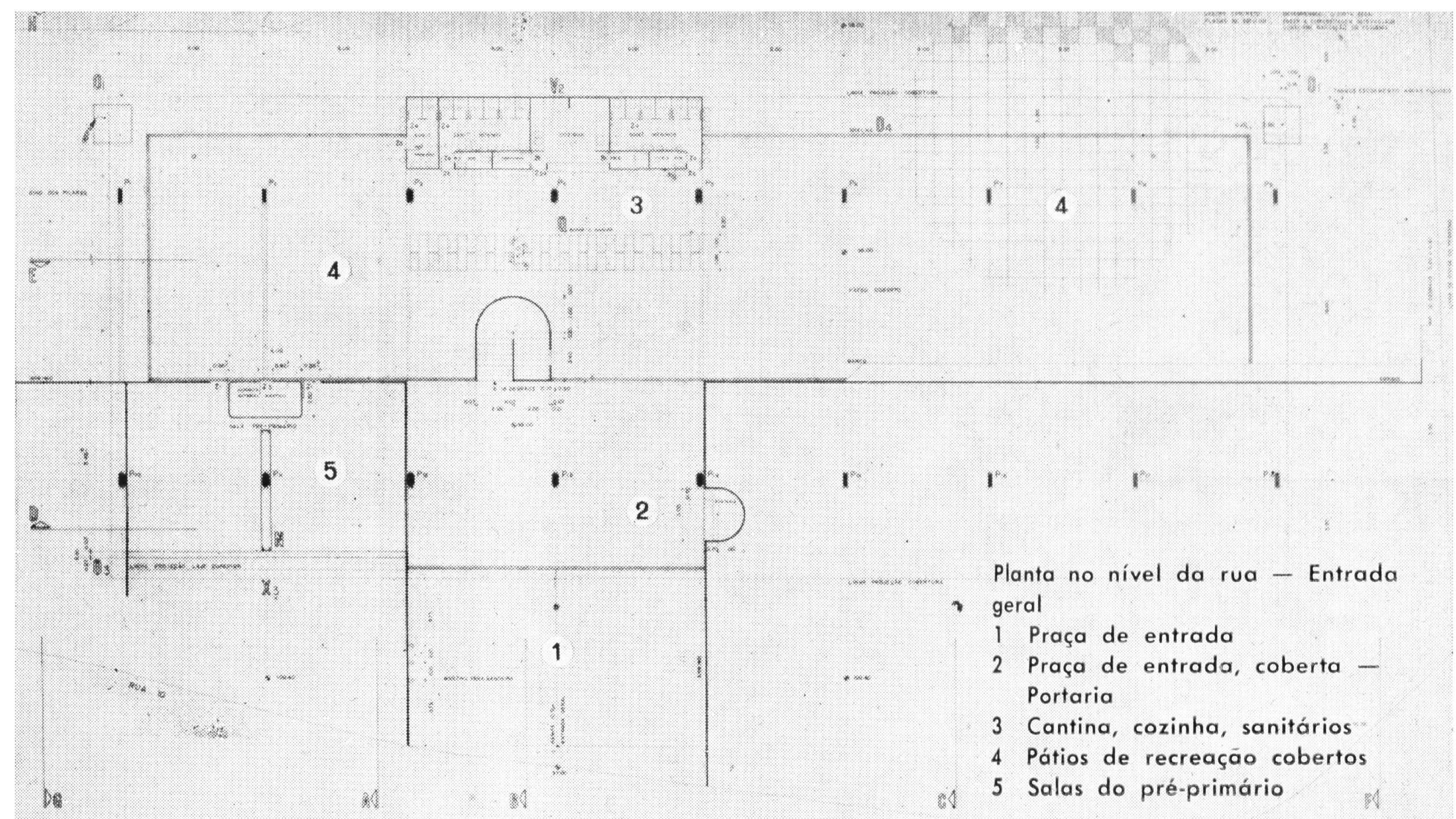




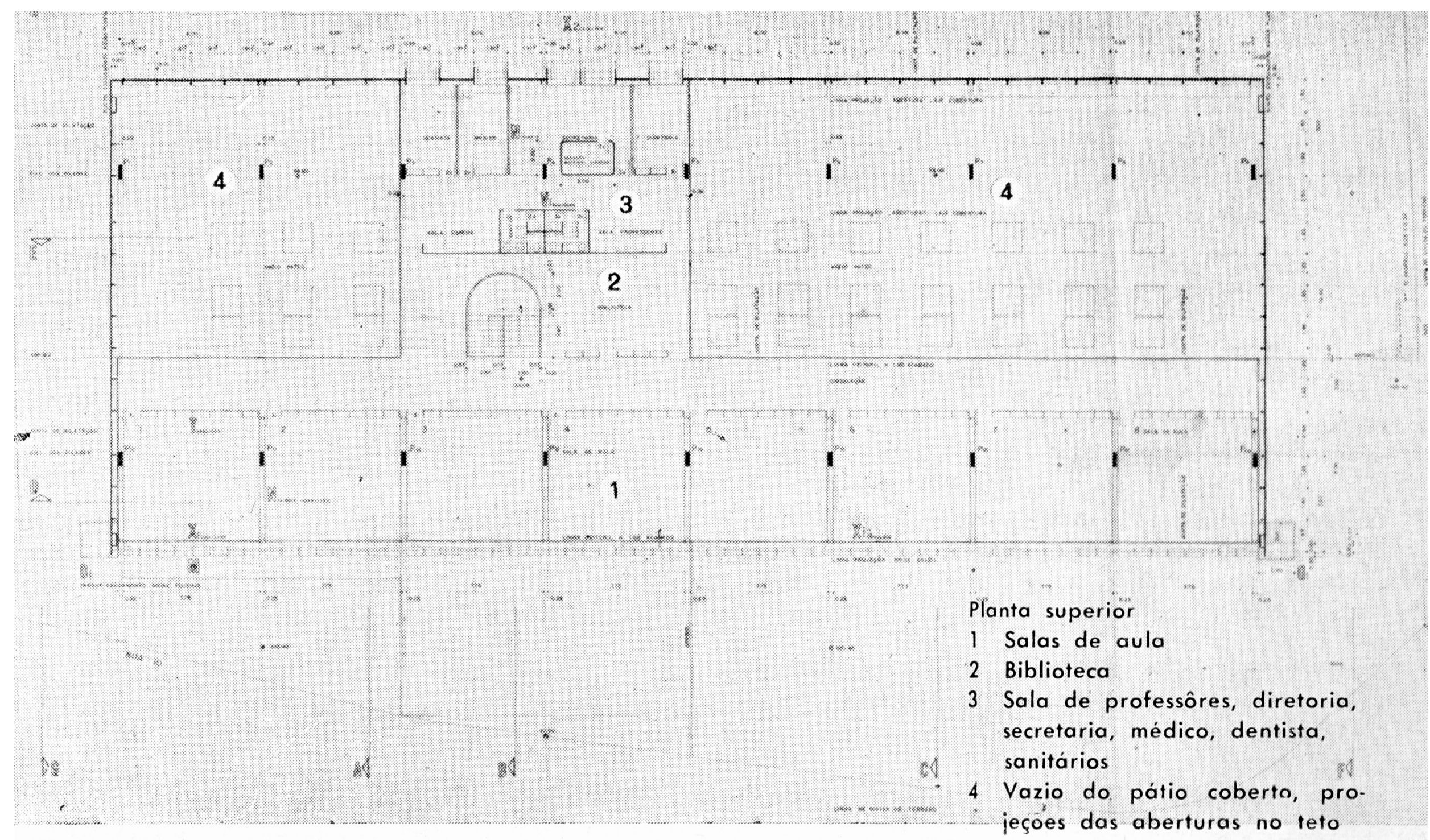



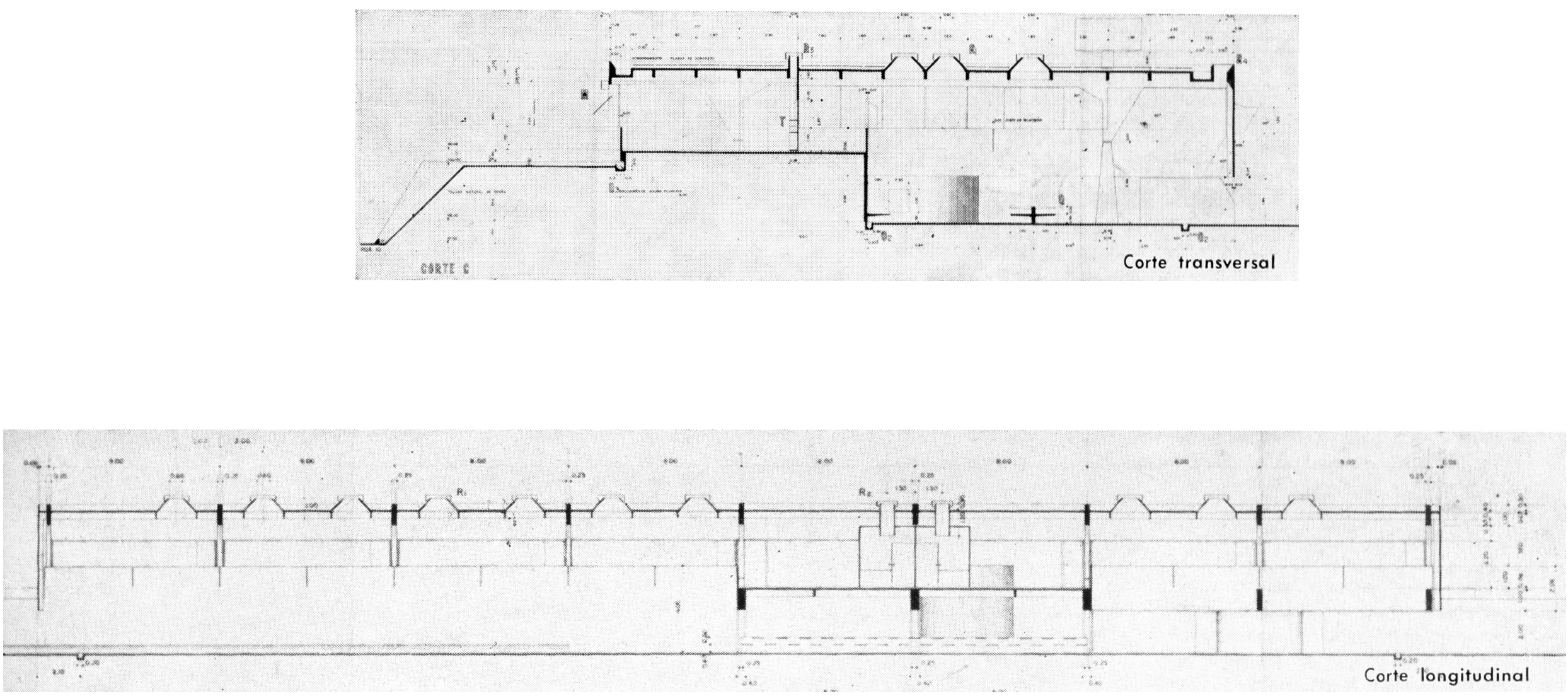

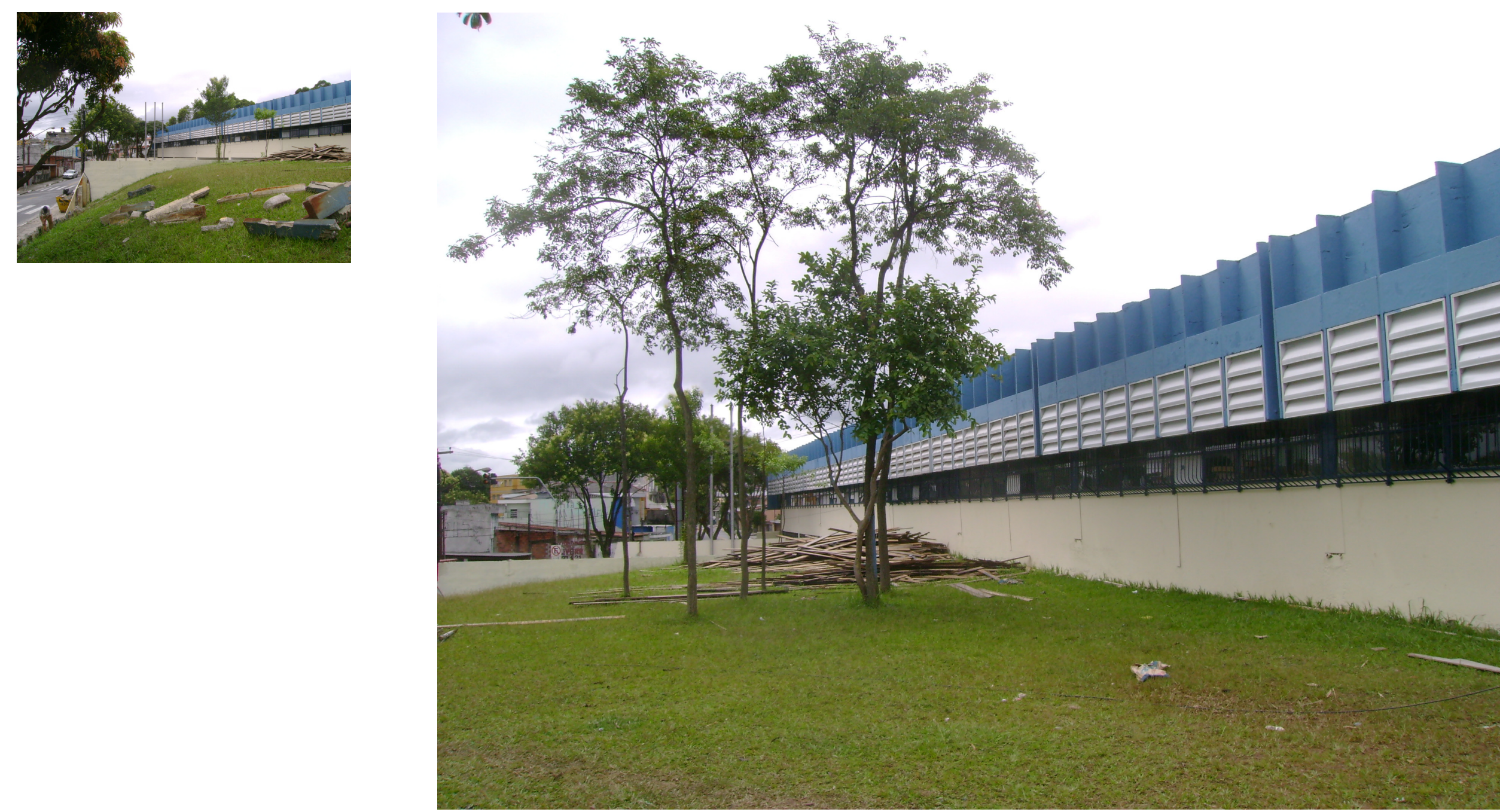


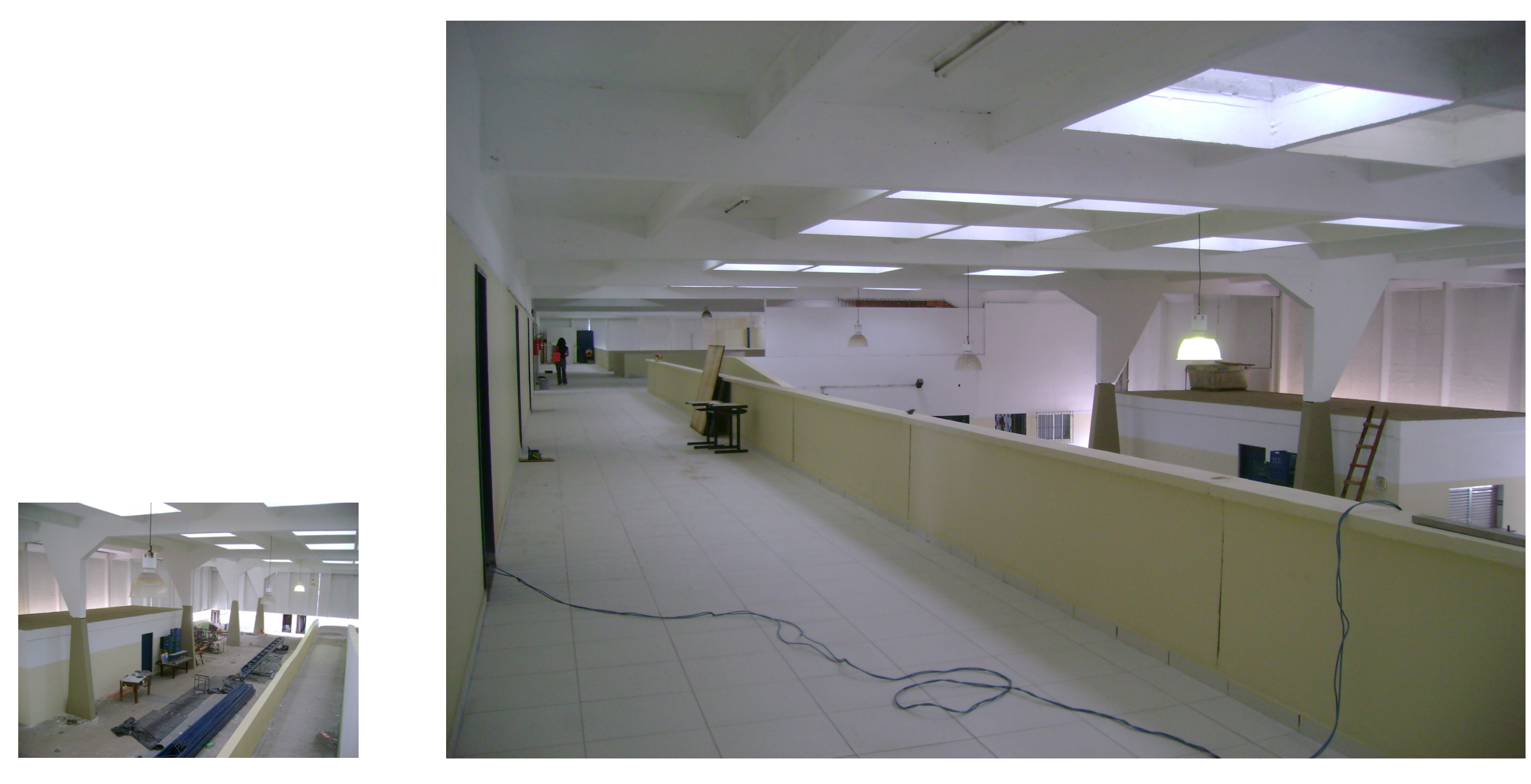




\section{EE Presidente Roosevelt / 1968}

Rua São Joaquim, 228, Liberdade. São Paulo, SP.

Arquitetos: Paulo Mendes da Rocha e Horácio Hirsch

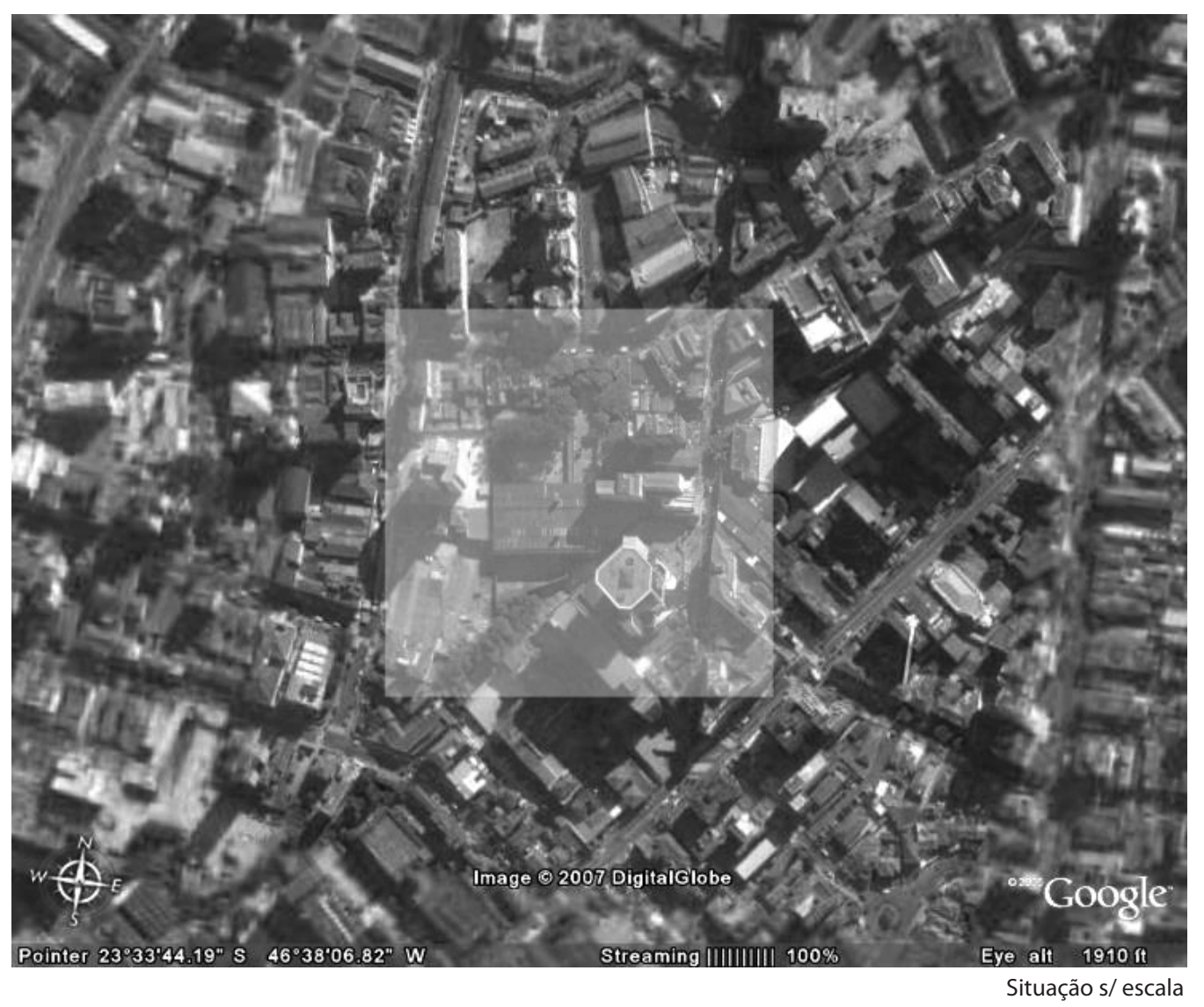




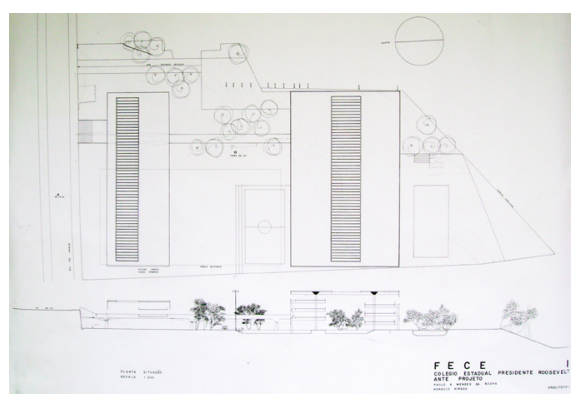

Em 1968, um ano após a realização do projeto da EE Gofredo T. da Silva Telles, Paulo Mendes da Rocha, em parceria com Horácio Hirsch, projetou essa escola para o FECE na cidade de São Paulo. Diferentemente das escolas anteriores, ela ocupa um trecho mais consolidado da cidade de São Paulo. No terreno em que está implantada existia já o tradicional colégio estadual Campos Salles, projetado em 1911 pelo arquiteto João Bianchi (anos depois a escola foi acometida por um incêncio e hoje encontra-se em ruínas)'1.

O colégio Campos Salles encontrava-se no alinhamento da rua e o terreno apresentava um forte desnível, o que levou os arquitetos a locar o novo bloco na porção sul do lote, que, no nível do pátio, encontra-se praticamente sete metros abaixo do nível médio da rua São Joaquim. O projeto original previa a demolição da antiga escola e em seu lugar a construção do pré-primário (como se pode observar no desenho ao lado; outro item que aparece nesse desenho é uma piscina no pátio sul, jamais construída).

O fato da construção anterior não ter sido demolida, aliado ao forte desnível do terreno, gerou uma implantação peculiar. Da rua praticamente não se vê a escola. Junto à calçada, um pequeno largo pavimentado anuncia o seu acesso (no projeto original o largo era previsto durante toda a largura do terreno). Dele, uma ponte conduz o transeunte, no nível da copa das árvores, à portaria, situada em nível intermediário. Daí pode-se divisar o grande vazio interno e coberto da escola, iluminado zenitalmente. Esse nível concentra as funções administrativas da escola (secretaria, diretoria, sala dos professores), bem como um pequeno museu e o grêmio dos alunos.

A construção, prisma retangular em concreto armado apoiado em pilares regularmente espaçados, como pilotis, reserva a maior parte do rés-do-chão para as atividades de recreio das crianças: quadra coberta e descoberta, cantina, banheiros, vestiários, zeladoria, pátios cobertos e descobertos.

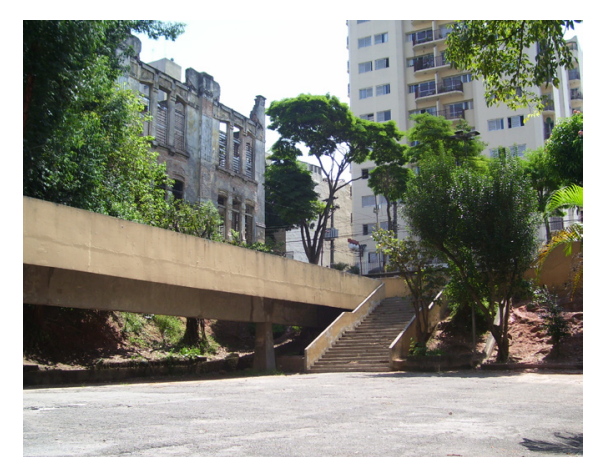

No vazio de quatorze metros de largura e quinze de altura há um jogo de rampas, responsável pela conexão entre as alas, desniveladas de meio em meio nível. A ala norte contém, além do bloco administrativo, dois níveis de sala de aula, oito em cada pavimento, voltadas para a mesma orientação e protegidadas da incidência direta da luz do sol por brises horizontais em concreto armado que também funcionam como contraventamento da estrutura. Os banheiros, localizados nas extremidades opostas do nível das salas de aula, instalados nos balanços da estrutura, completam a organização desse piso. A ala sul abriga, no nível intermediário, as salas de atividades 

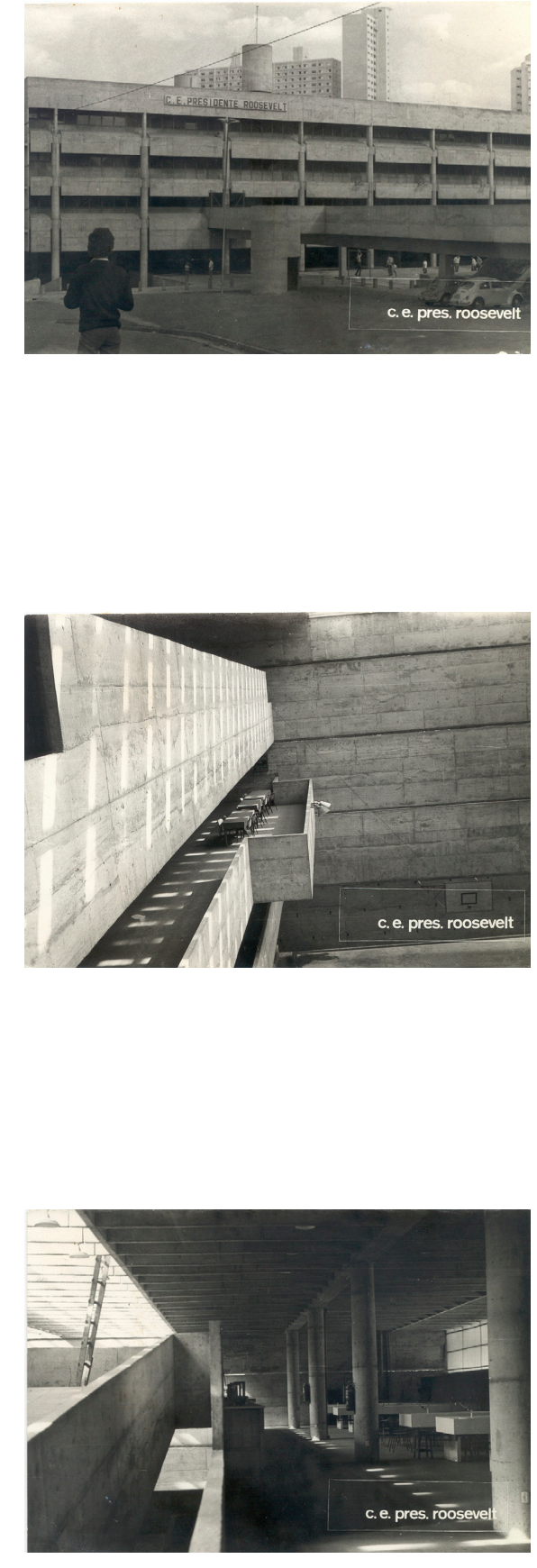

especiais: artes industriais, técnica comercial, música, costura, culinária e artes plásticas; acima dele, biblioteca, pós-graduação, estudos sociais e anfiteatros; no último pavimento (de um pé-direito e meio), os laboratórios.

A estrutura da escola foi pautada pelo módulo dos caixilhos, sete caixilhos de $1.00 \mathrm{~m}$ de largura por $2.50 \mathrm{~m}$ de altura em cada módulo de sala de aula, mais dois em cada extremidade. Constituídos de peças pré-moldadas em argamassa armada, ferro e vidro, com mecanismo de abertura semelhante ao da casa do próprio arquiteto: basculante e com o eixo deslocado do centro, de modo que uma vez destravado, chega à posição de destino com seu próprio peso e a força da gravidade.

Outra consideração que não se pode deixar de mencionar é o parentesco do projeto dessa escola com a Faculdade de Arquitetura e Urbanismo da Universidade de São Paulo. No momento de elaboração do projeto da EE Presidente Roosevelt, o edifício da faculdade estava em construção². Esse parentesco aparece, principalmente, na organização do programa em duas alas paralelas separadas pelo vazio iluminado zenitalmente e nas rampas que interligam os pavimentos, defasados em meios níveis.

Um intervalo de seis anos separa o projeto da inauguração da escola, ocorrida em 1974. Durante esse período algumas alterações surgiram em relação ao projeto original. Talvez a mais significativa tenha sido o acréscimo de uma sucessão de pilares nas faces norte e sul do edifício (originalmente os pilares não prosseguiam até a cobertura). Tal alteração modificou também o desenho da cobertura: as vigas contínuas foram substituídas por trechos de vigas apoiadas nos balanços da estrutura, através de juntas tipo "gerber" e as aberturas zenitais, pensadas como molduras em argamassa armada de $94 \mathrm{~cm}$ por $94 \mathrm{~cm}$ e vidro simples, foram substituídas por cambotas de fibra de vidro.

A escola hoje se encontra bastante deteriorada. Muitas ampliações ("puxadinhos") foram feitas nos pavimentos (muito provavelmente em função das alterações programáticas pelas quais a escola passou) e o largo de acesso foi gradeado. Assim sendo, o uso da ponte deixou de fazer parte do cotidiano da escola, o que acabou por descaracterizar o edifício escolar em relação ao projeto original. 


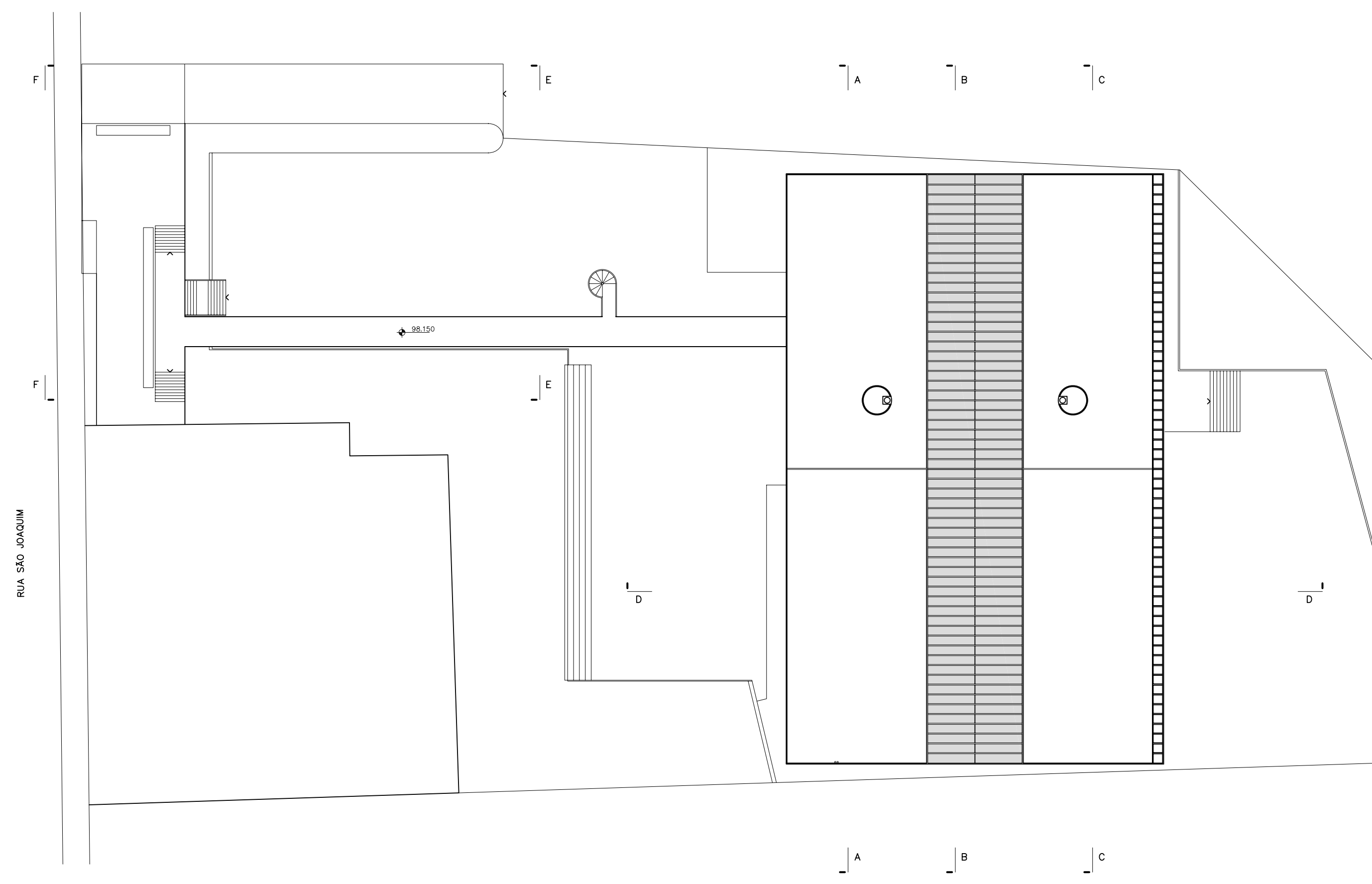

PLANTA DE COBERTURA ESC. 1:500 = 


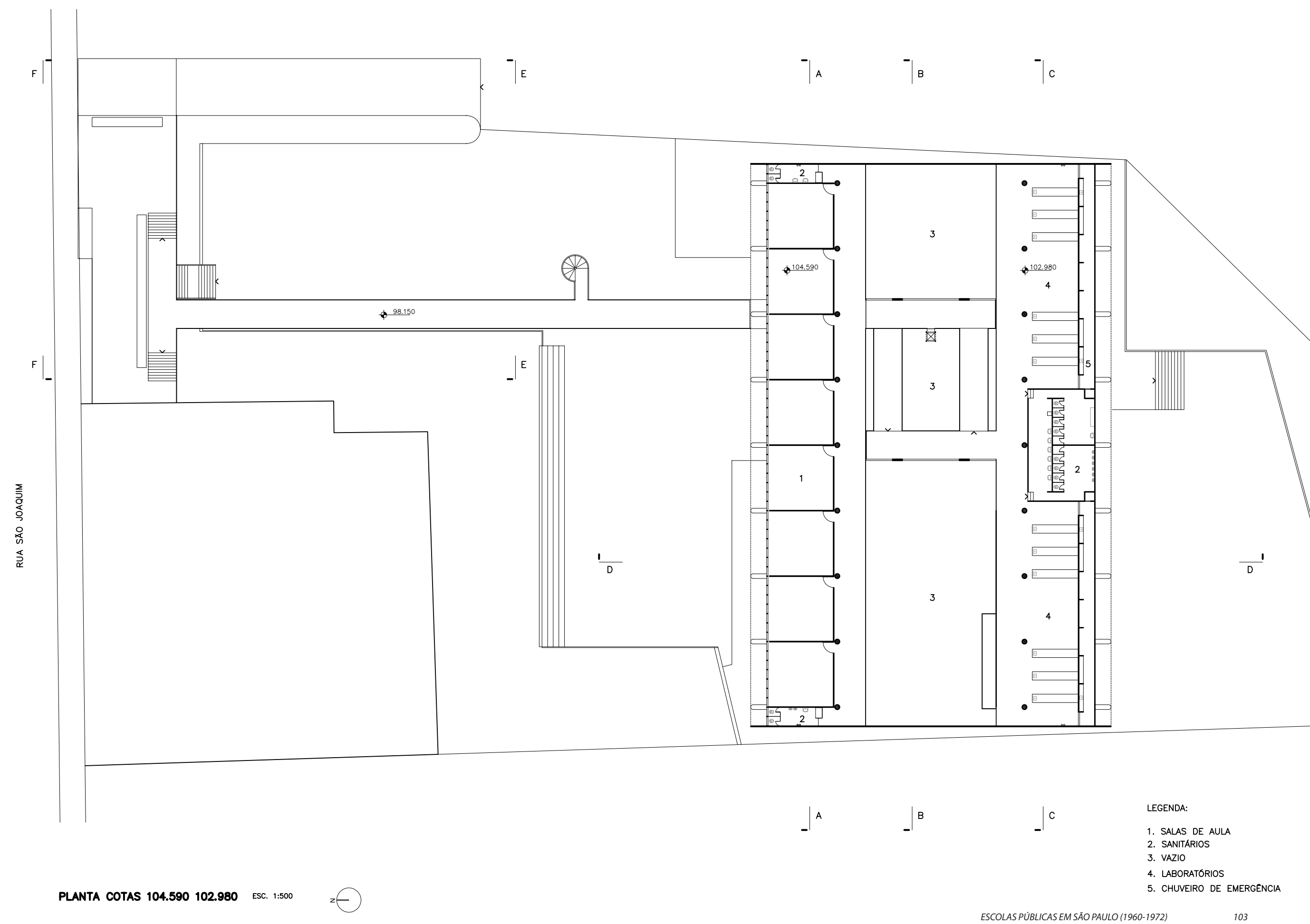




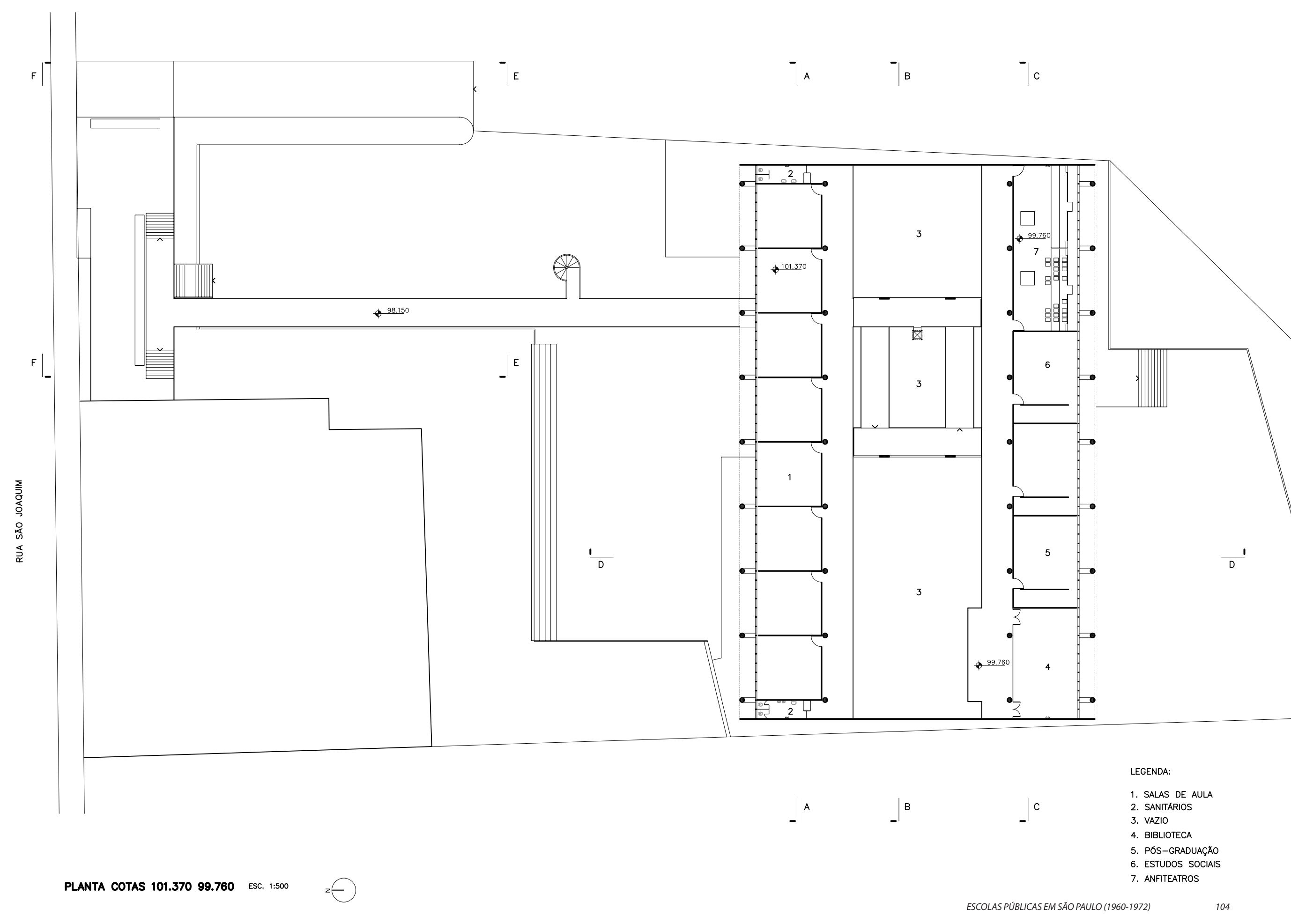




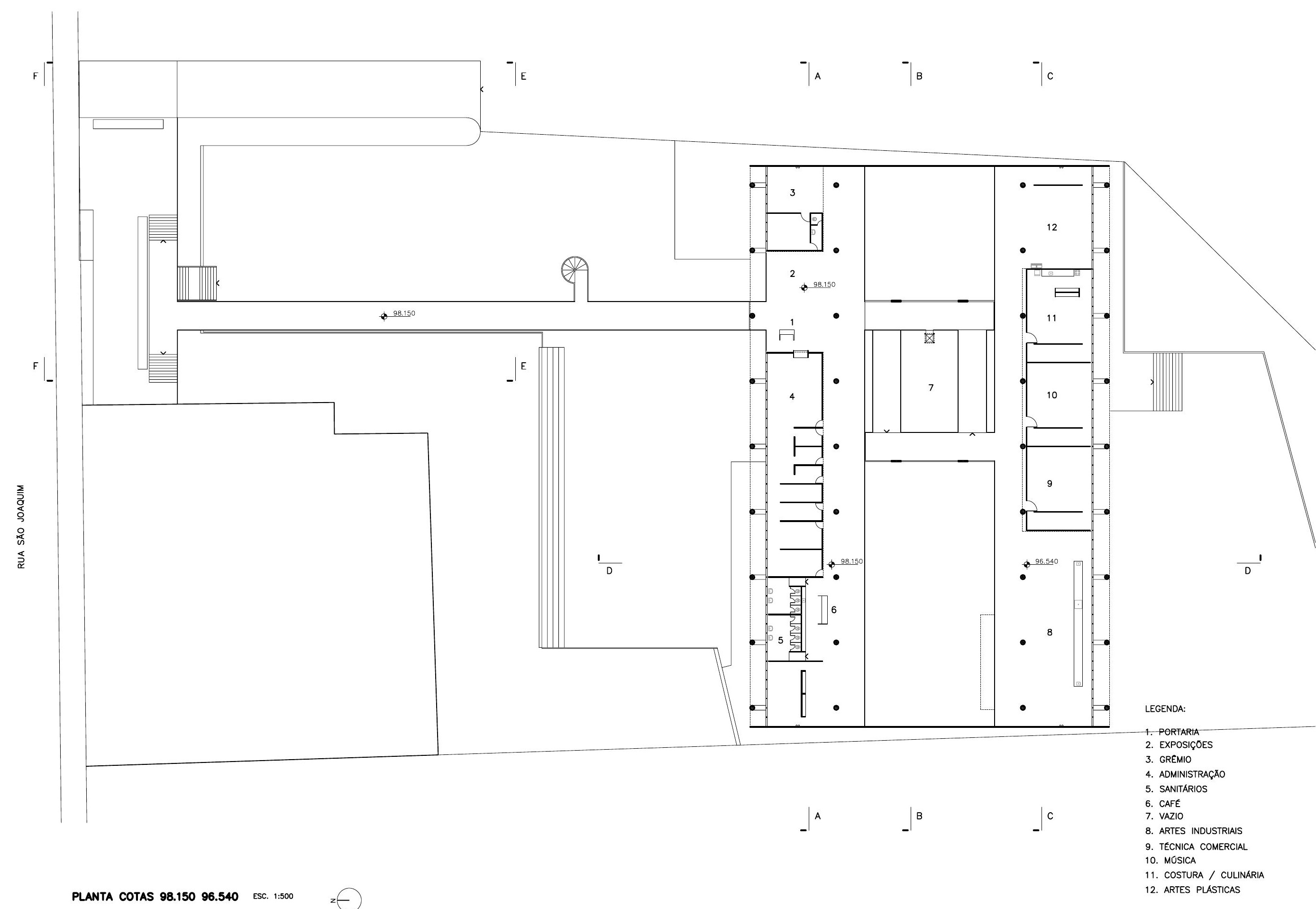




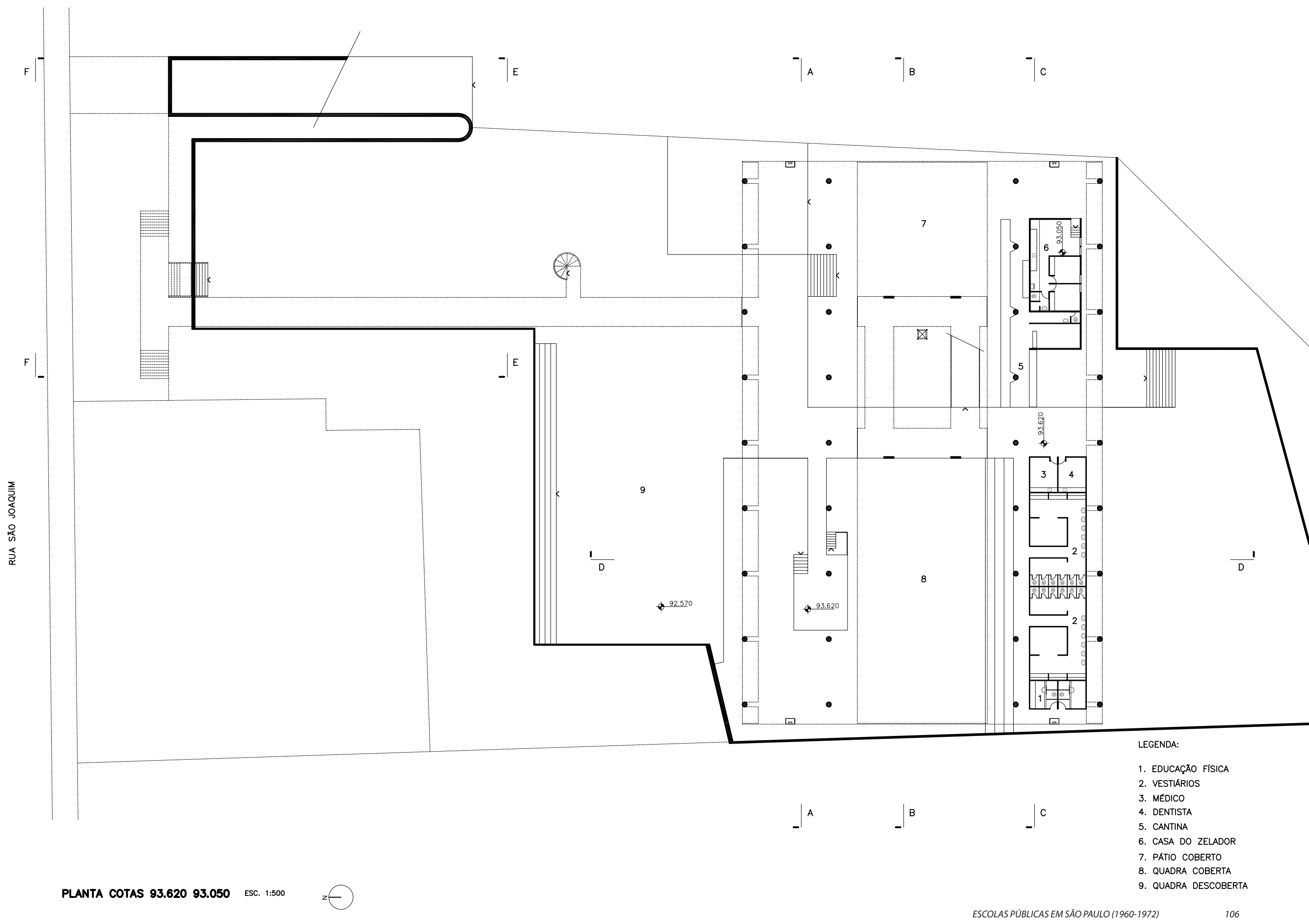




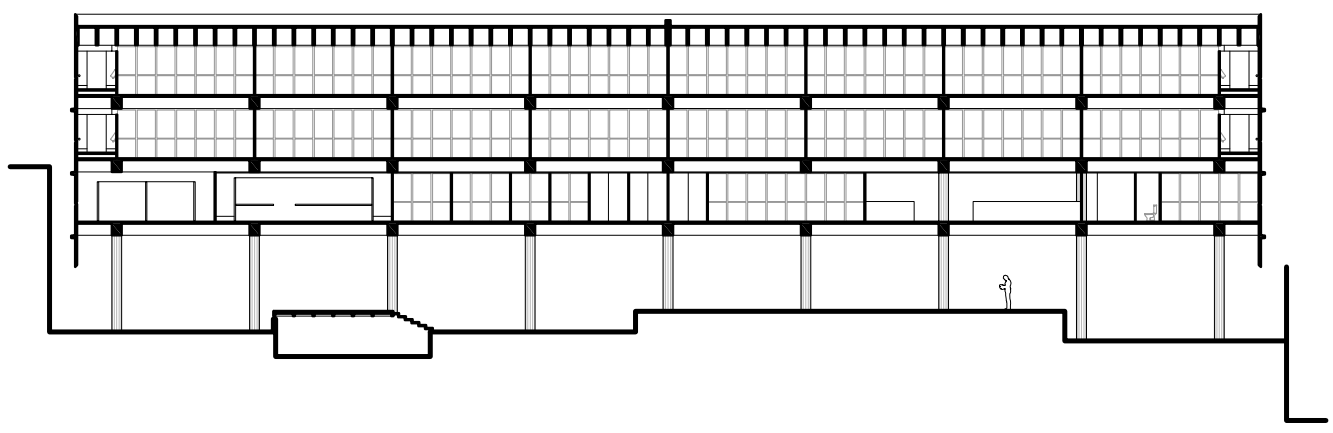

CORTE AA ESC. 1:500

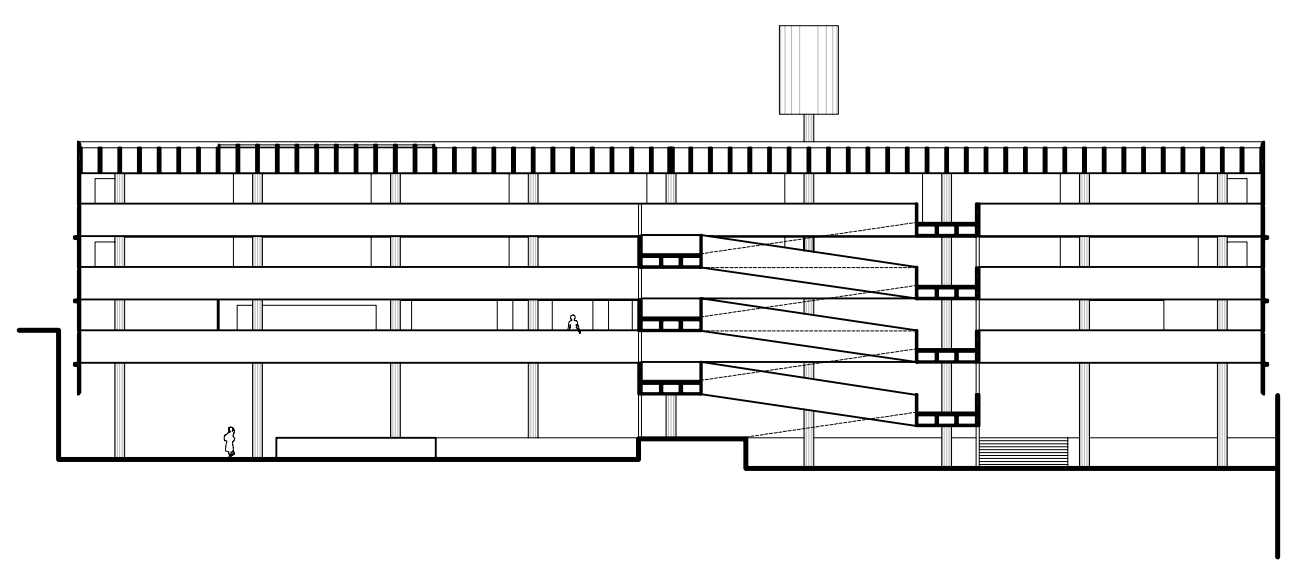

CORTE BB ESC. 1:500

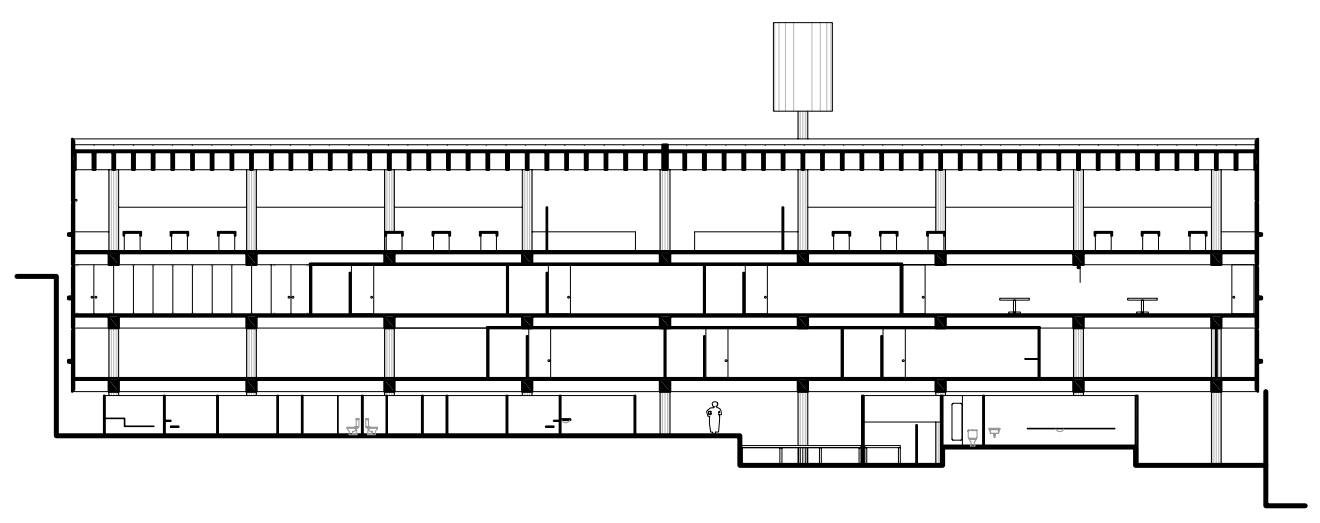




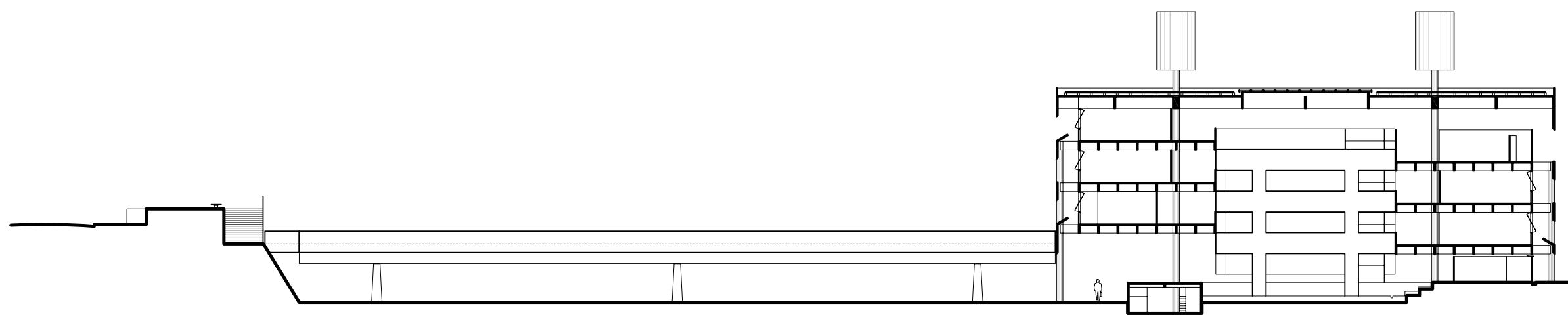

CORTE DD ESC. 1:500
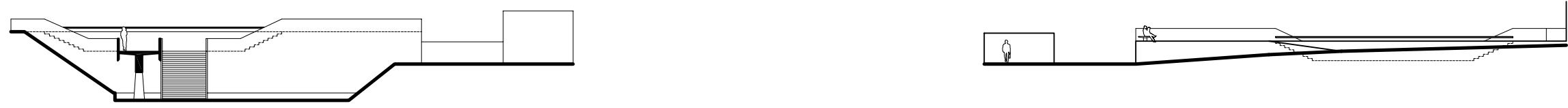

CORTE EE ESC. 1:500 


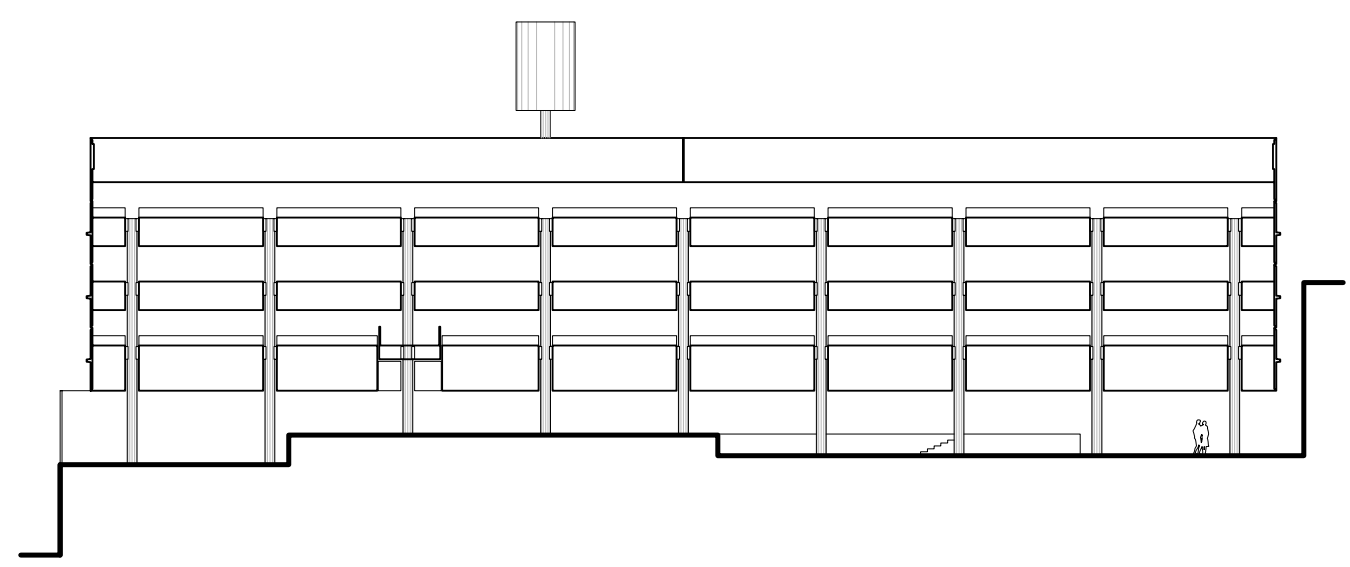

ELEVACAAO NORTE ESC. 1:500

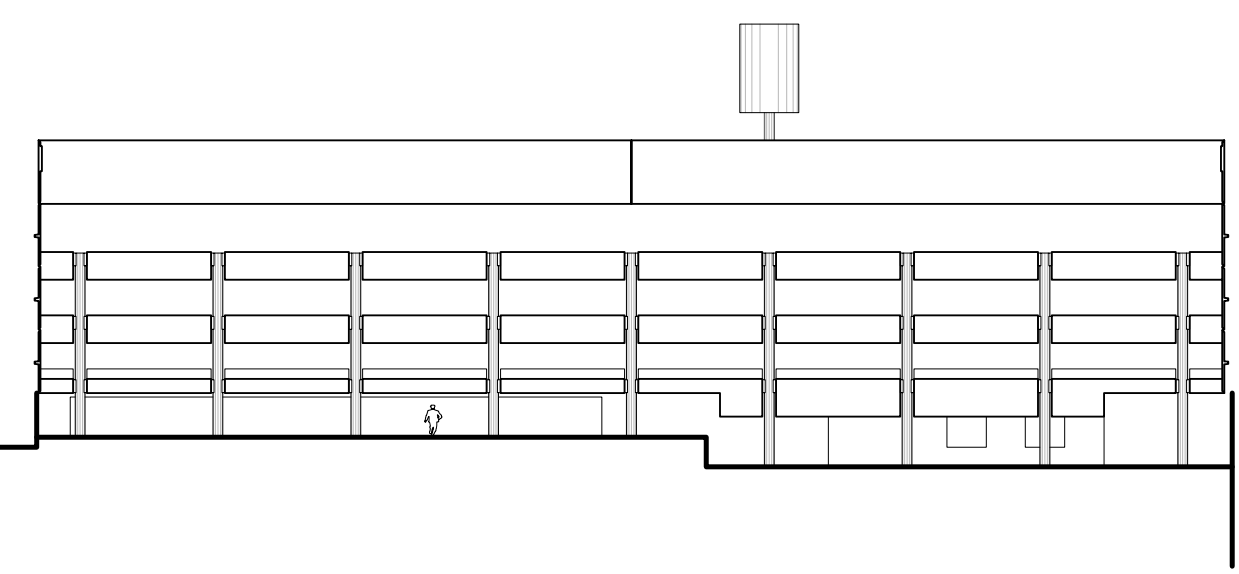



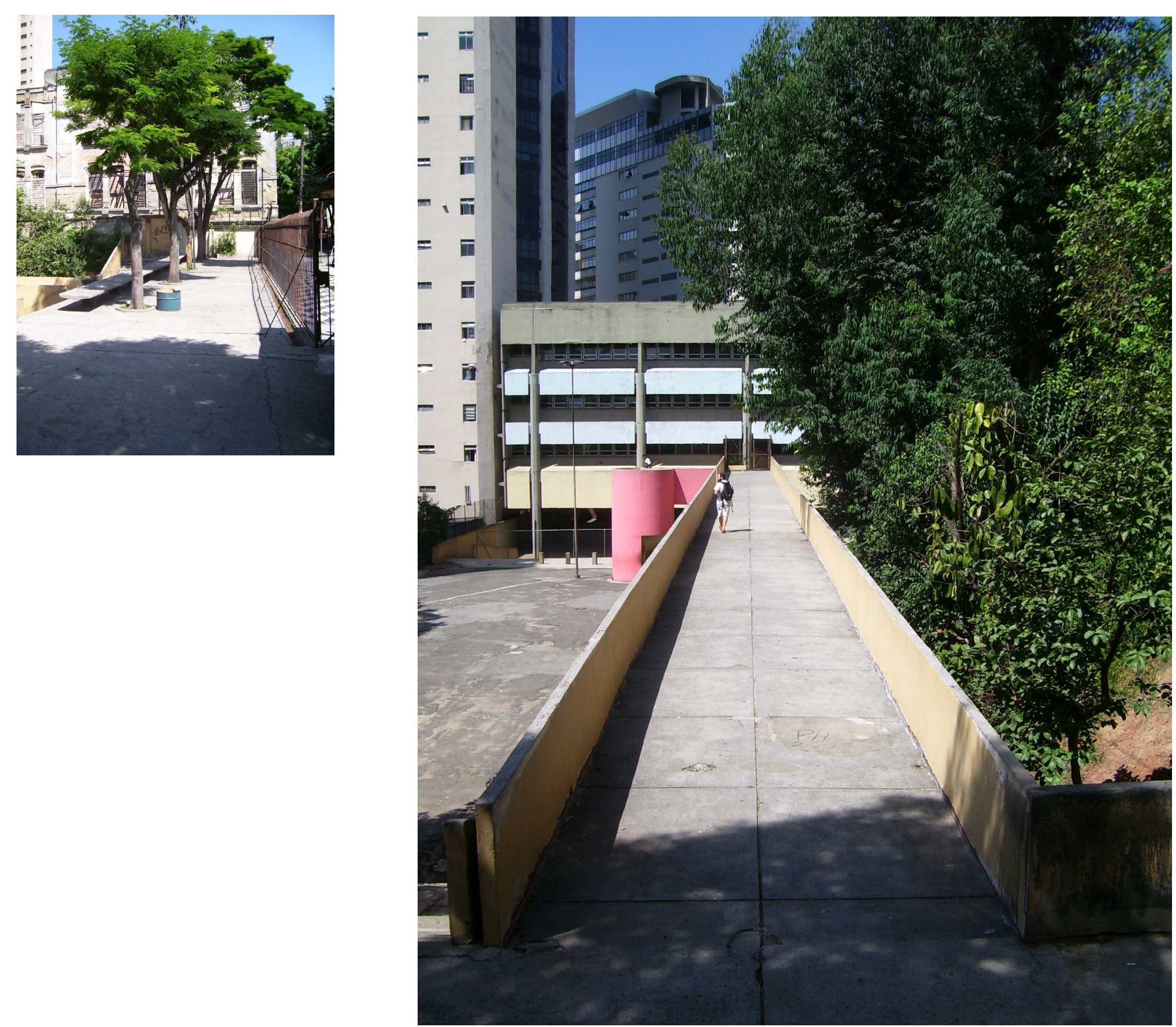

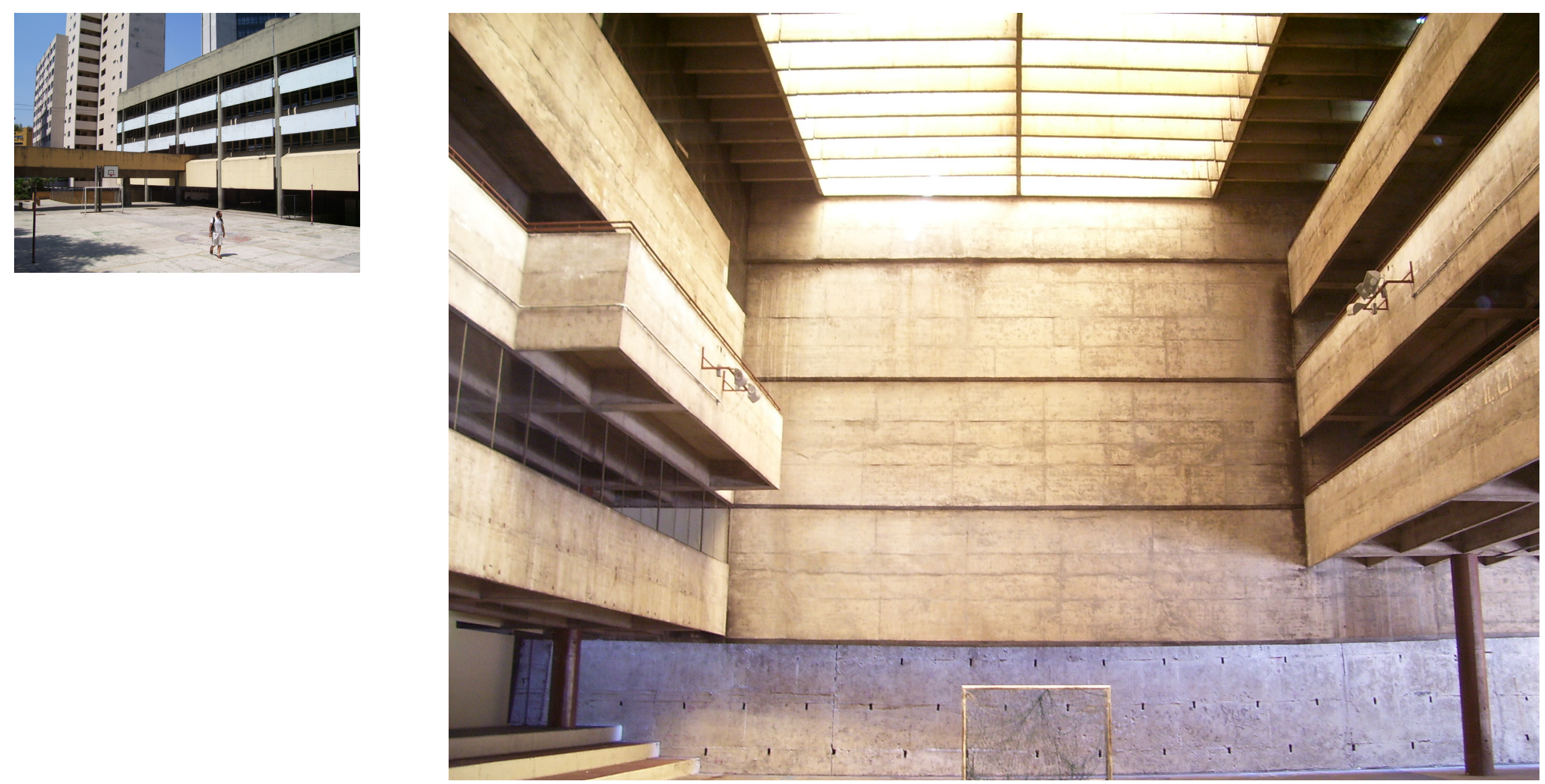

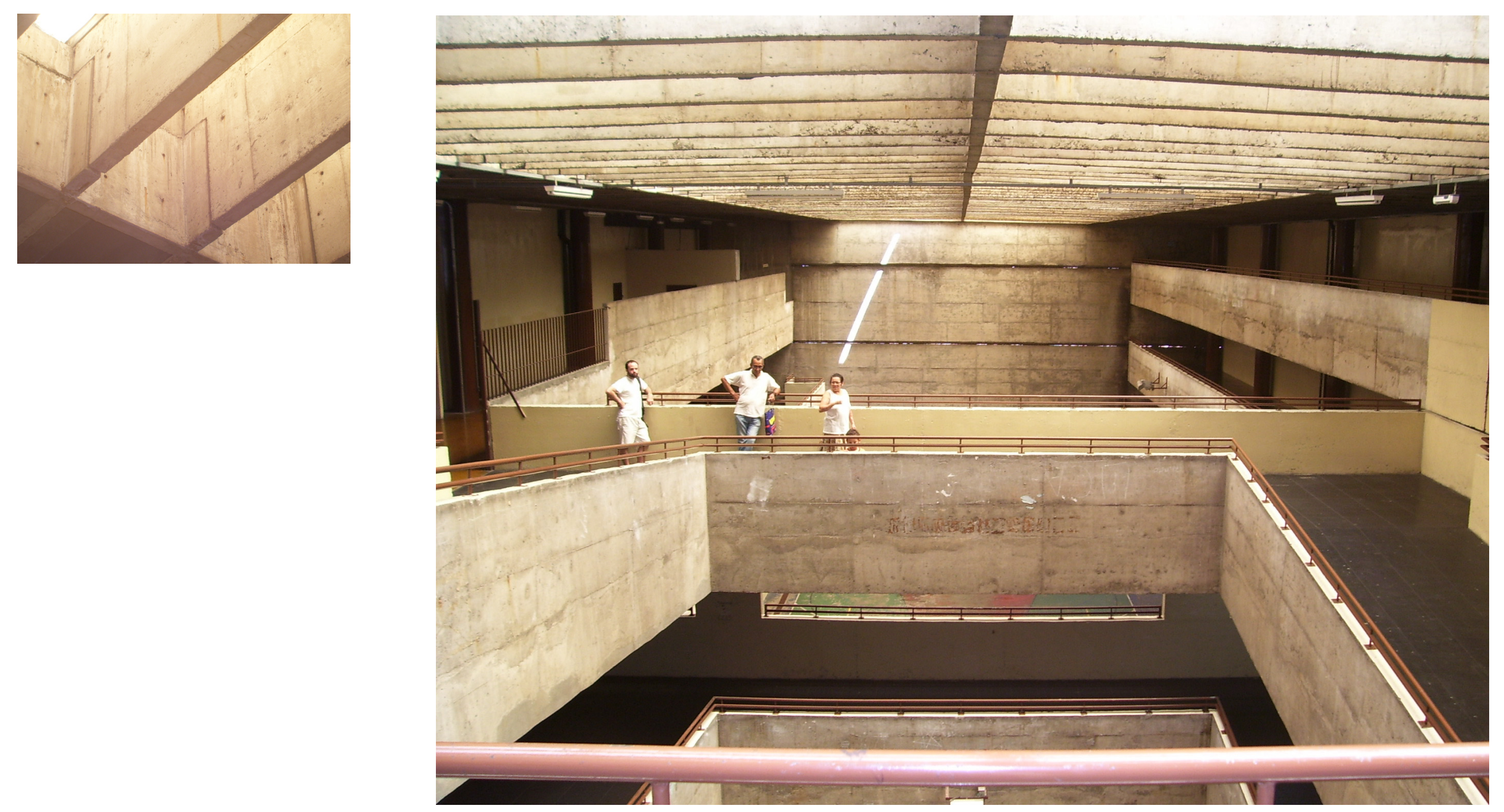

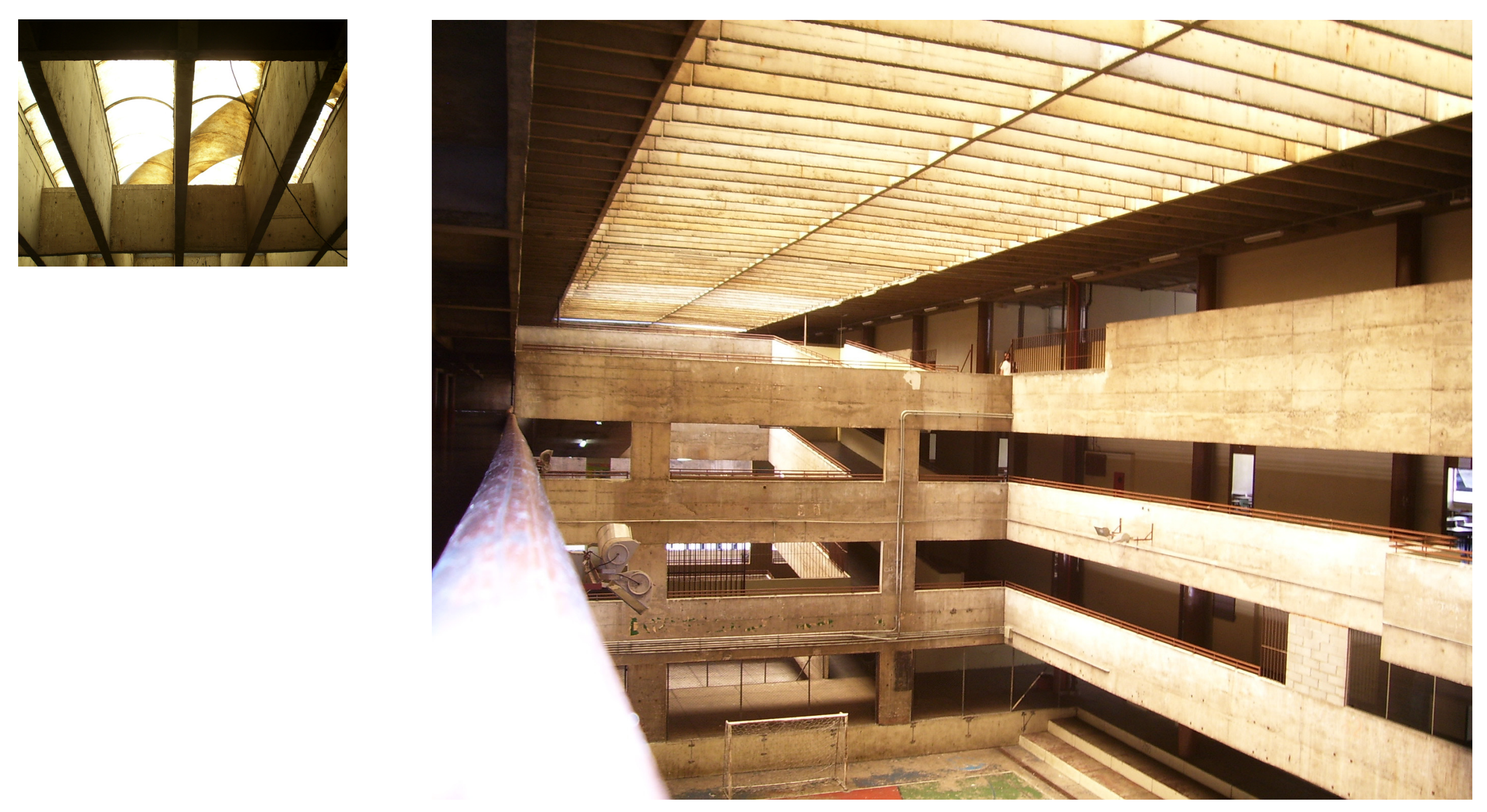
Rua Cabral da Câmara, 57, Jardim Embaré. São Bernardo do Campo, SP.

Arquiteto: Paulo Mendes da Rocha

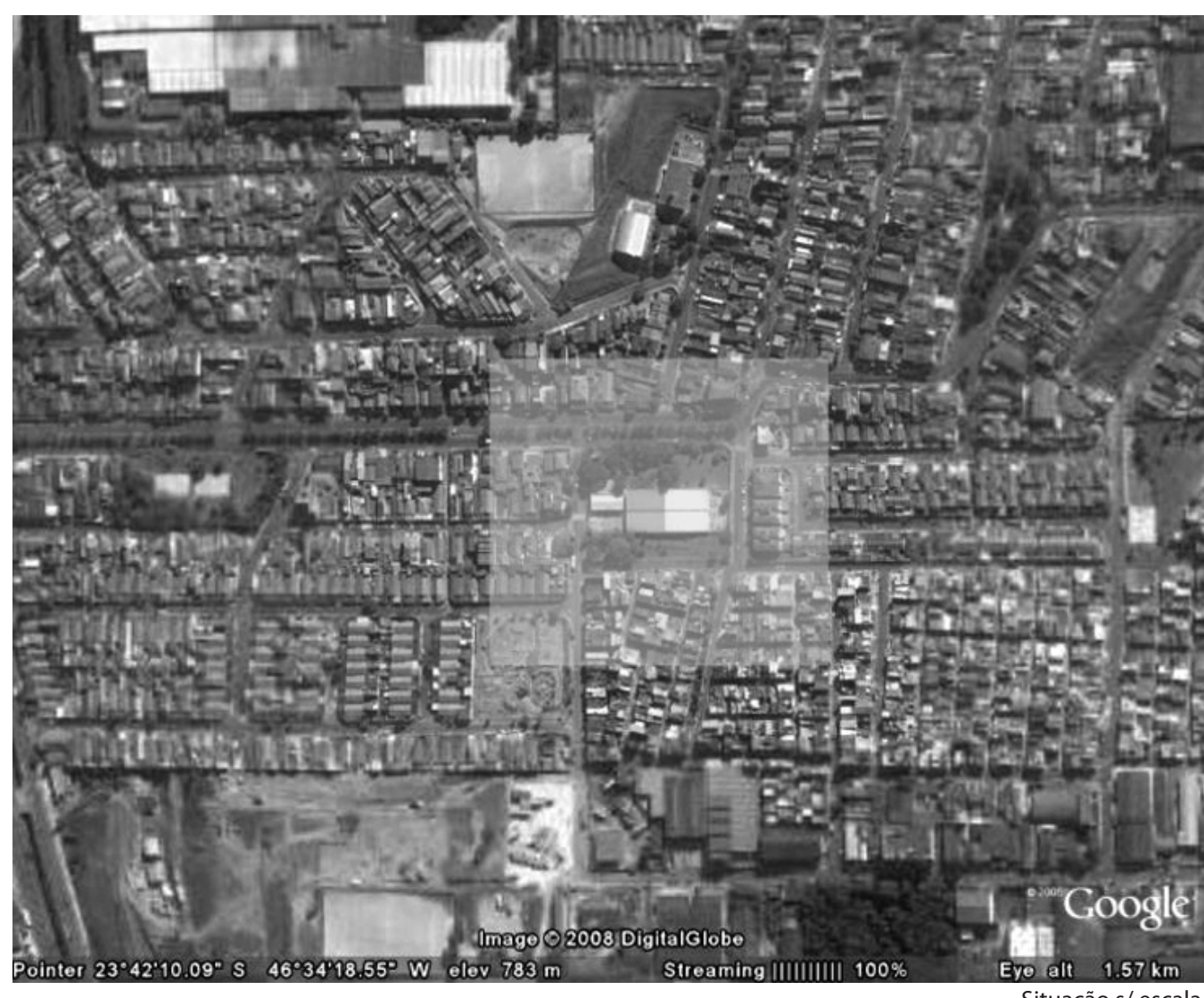

Situação s/ escala 

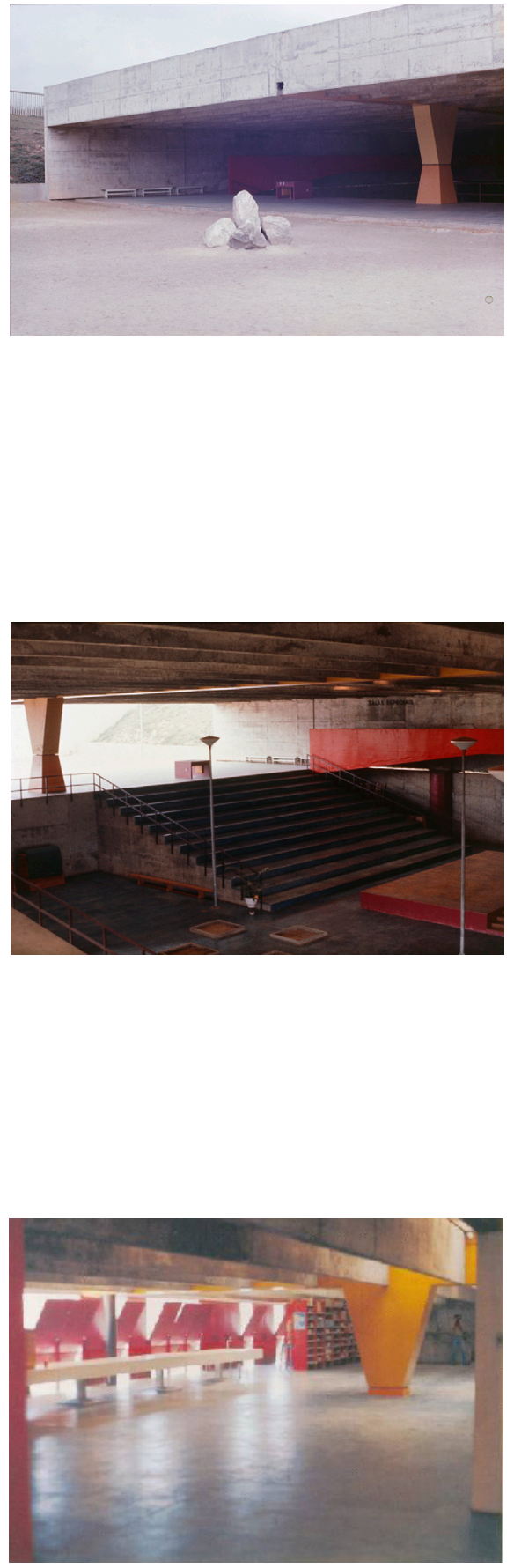

Enfatizando o papel da escola como uma instituição ponte entre a família e o espaço social mais amplo, Paulo Mendes da Rocha lembra (informação verbal)' a origem grega da palavra escola: scholé, que significa lugar do ócio, do tempo livre. Daí proviria a importância do pátio de recreação como ambiente socializador, democrático. A terceira escola desenhada por ele em São Bernardo do Campo, destinada originalmente à educação infantil, materializa esse significado pois é essencialmente lugar do recreio, da atividade lúdica.

O térreo, que serve de conexão entre ruas, abriga os pátios (originalmente um continha areias e rochas e o outro, um lago), a cantina, a administração e um pequeno auditório aberto. No pavimento superior, as salas de aula, oficinas, biblioteca e banheiros das crianças estão agrupados num grande salão que pode ser acessado pelas duas extremidades do edifício, ora por uma rampa-ponte, ora por uma escada metálica helicoidal. Os espaços das salas de aula são divididos apenas por leves painéis de argamassa armada e o fechamento externo, feito por painéis basculantes em madeira, pintados de vermelho.

Três vigas paralelas e longitudinais ao terreno apóiam as nervuras da cobertura translúcida². Duas empenas, apoiadas em quatro pilares de seção circular, localizam-se nas extremidades Norte e Sul. Uma viga calha central, apoiada por outros três pilares de seções quadradas e variáveis, complementa a composição. Outro pilar, o oitavo, de seção circular, existe só até o nível do salão das aulas, museu e oficinas.

A escola foi adaptada pelo município como uma EMEB (Escola Municipal de Ensino Básico), o que resultou na instalação improvisada de oito salas de aula na laje do salão superior, de modo que metade das salas não conta atualmente com iluminação e ventilação naturais. A cobertura foi trocada por telhas opacas, o que prejudica a iluminação interna do edifício. Outra alteração foi a construção de um anexo no pátio do lago e o fechamento do pátio das pedras. Tanto o lago como as rochas já não existem mais. Eles serviam de receptáculo das águas pluviais, provenientes da viga calha central, o que devia representar nos dias de chuva um espetáculo à parte.

Entrevista realizada com o arquiteto em 26/03/2007.

Segundo o arquiteto Paulo Mendes da Rocha na entrevista citada acima, as indústrias Laffer produziram especialmente para essa obra placas de fibra de vidro que, apoiadas sobre uma grelha de concreto armado de $10 \mathrm{x} 10 \mathrm{~cm}$, permitiam a iluminação uniforme de todo o ambiente da escola, sombreado por essa mesma malha de concreto nos momentos de maior incidência da luz do sol. 

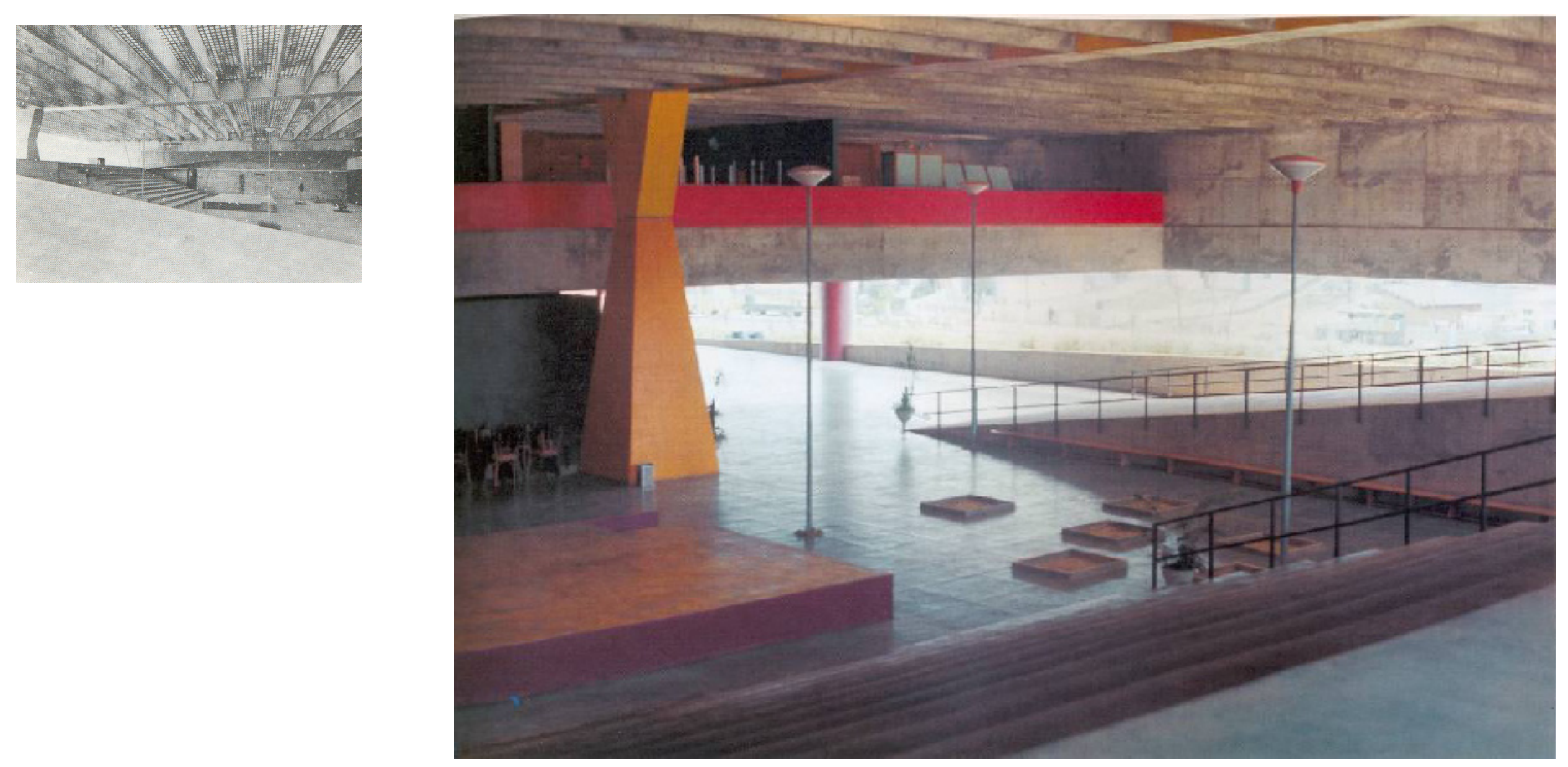


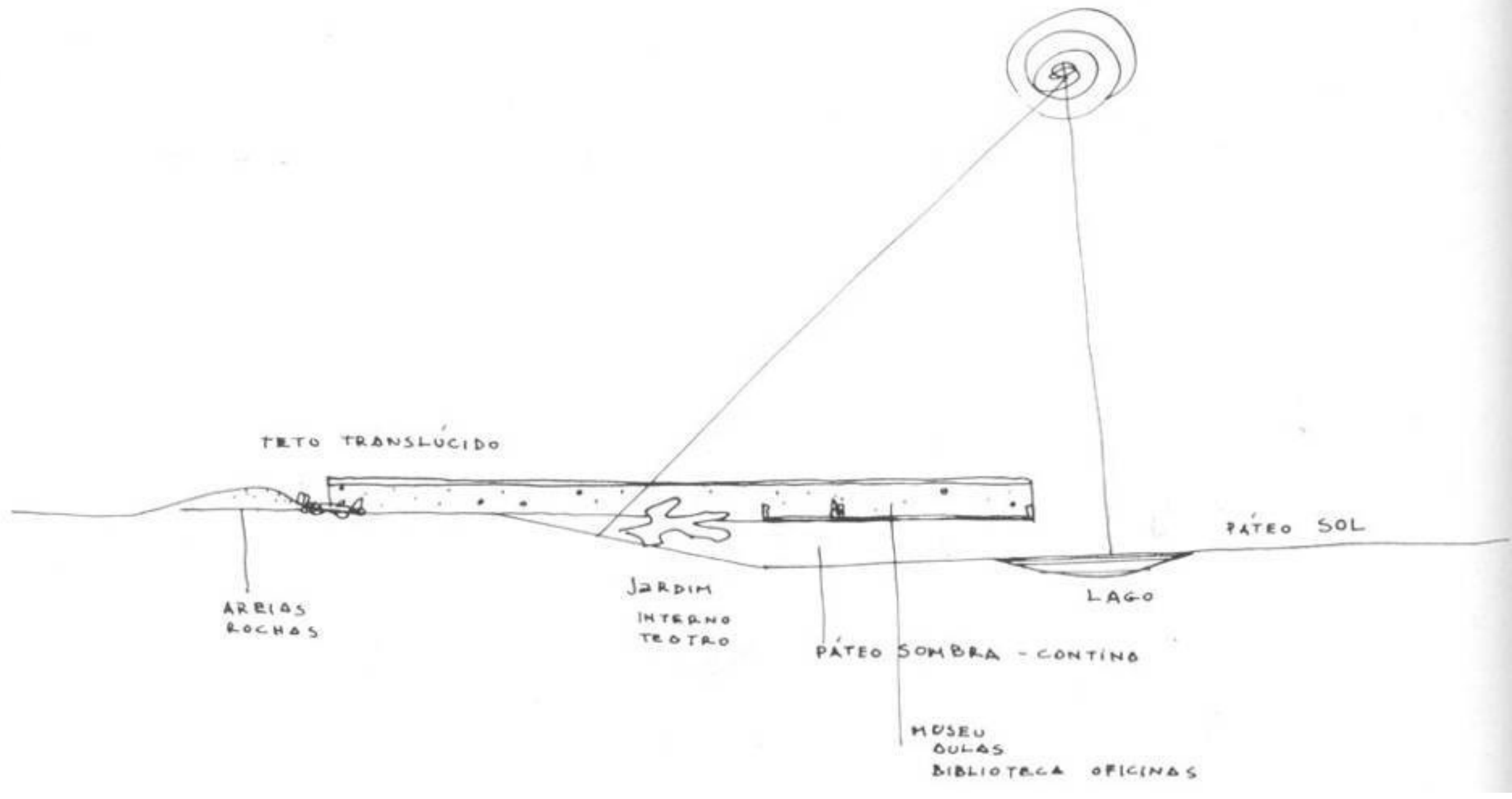


Corte longitudinal e plantas do pavimento superior e térreo s/ escala

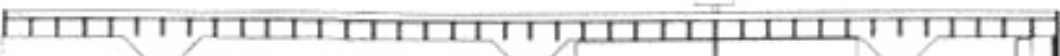
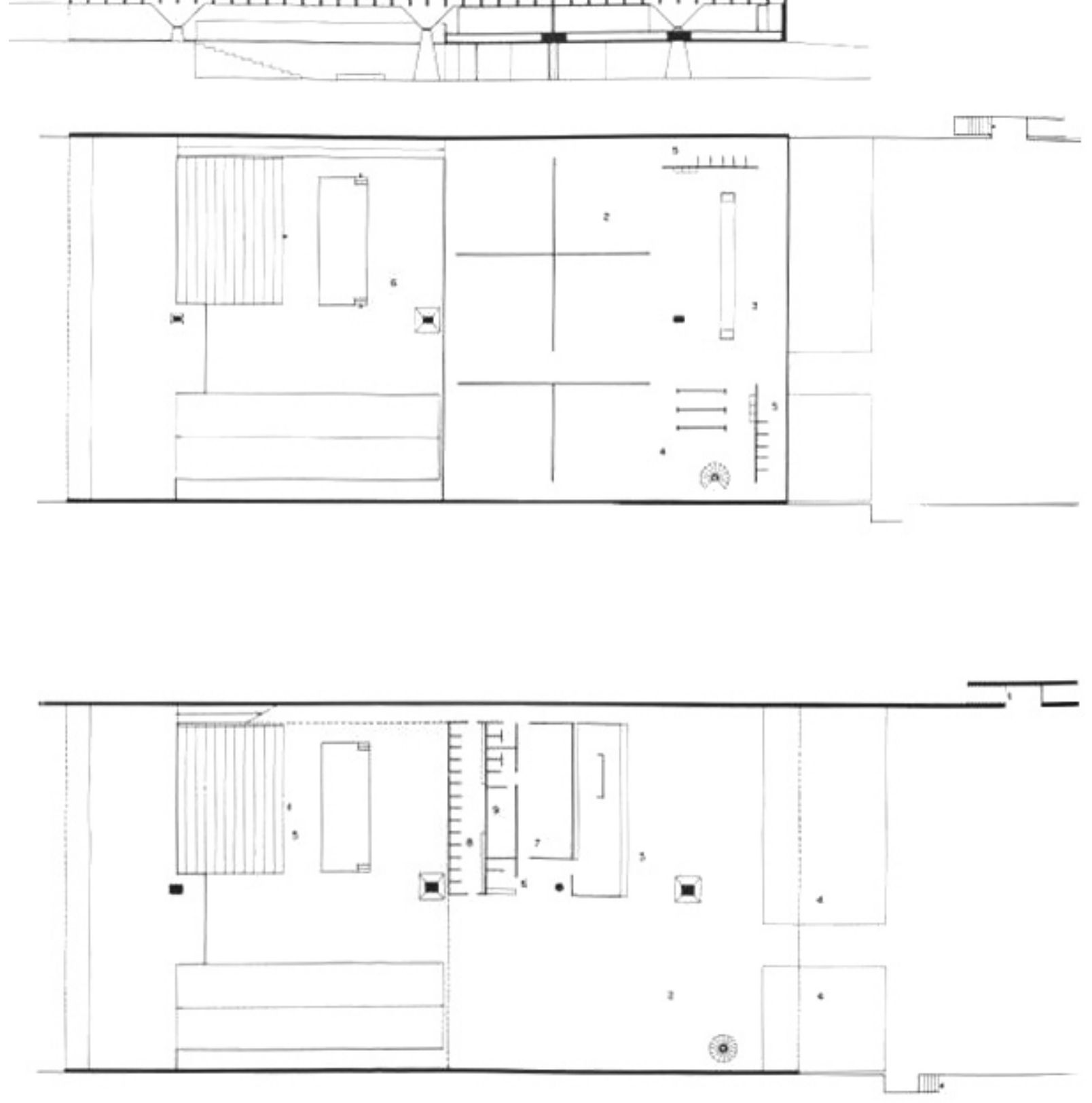
Croquis feito pelo arquiteto Paulo Mendes da Rocha durante a entrevista relaizada em 23/03/2007

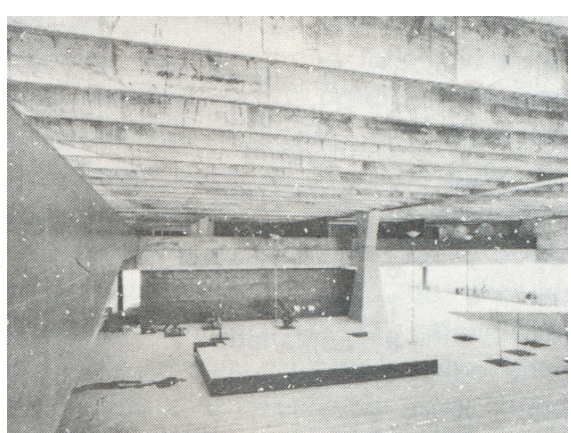

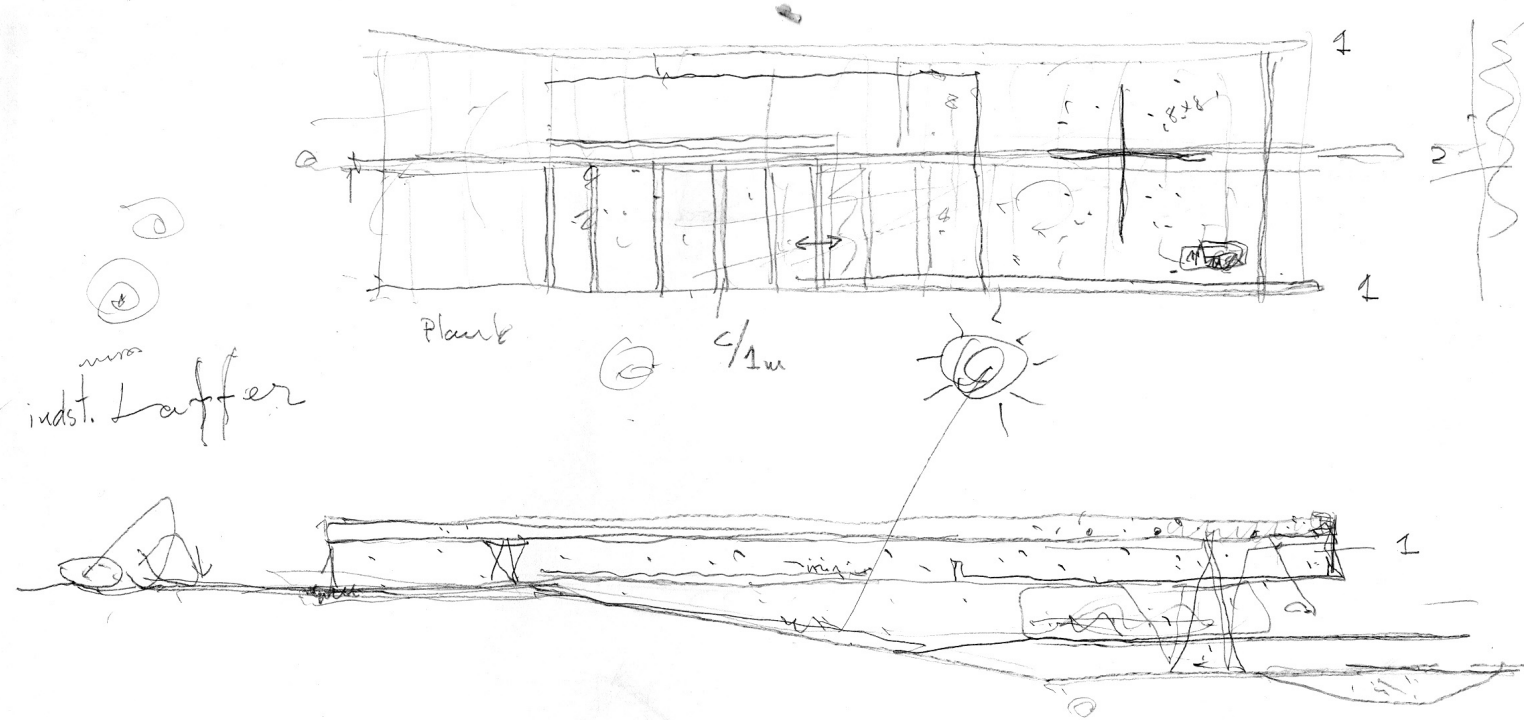

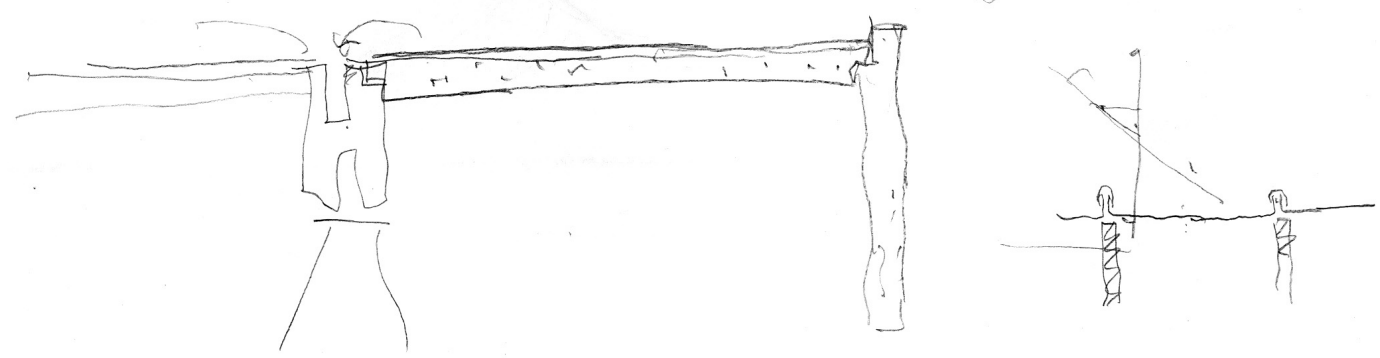



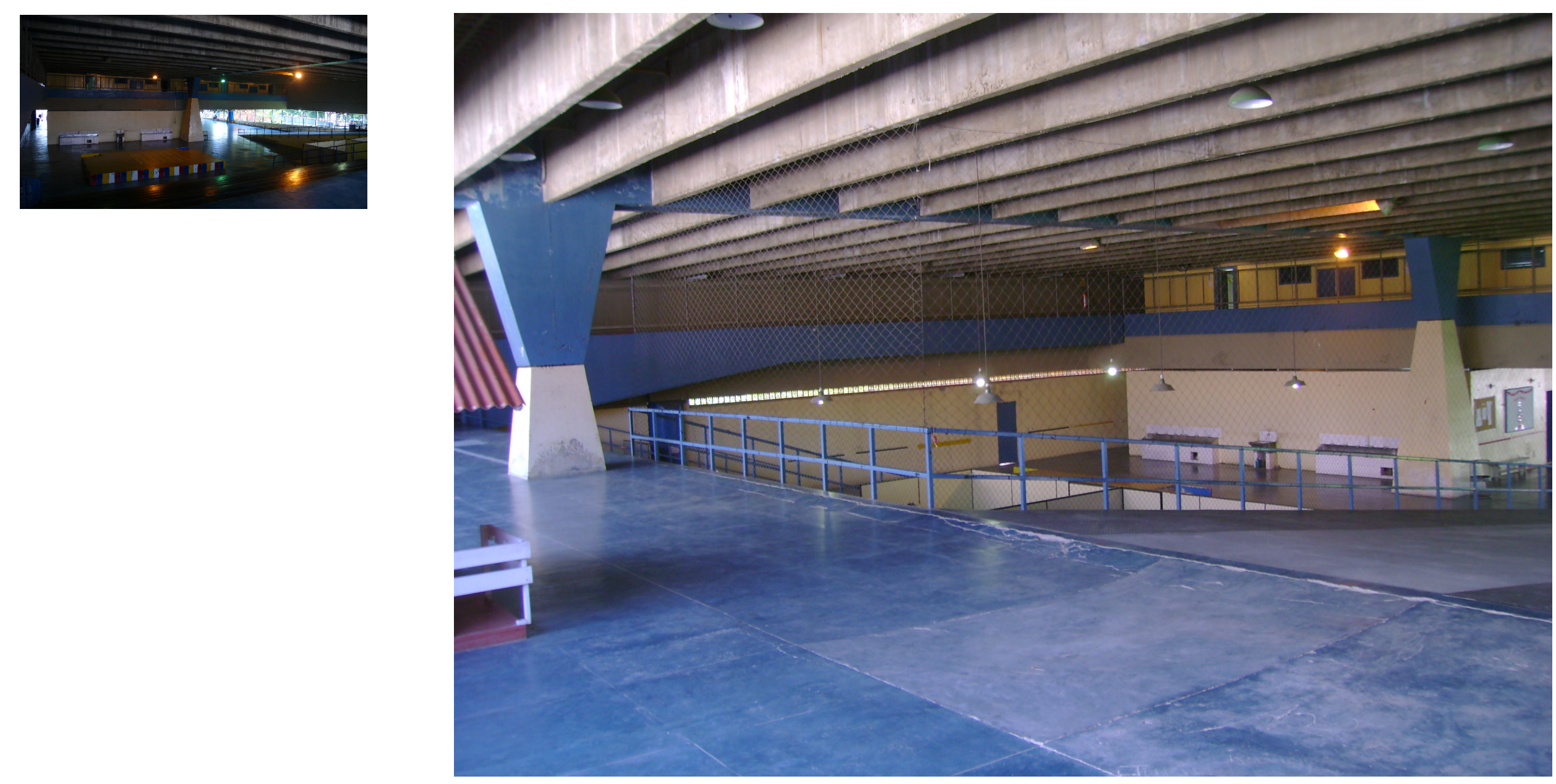

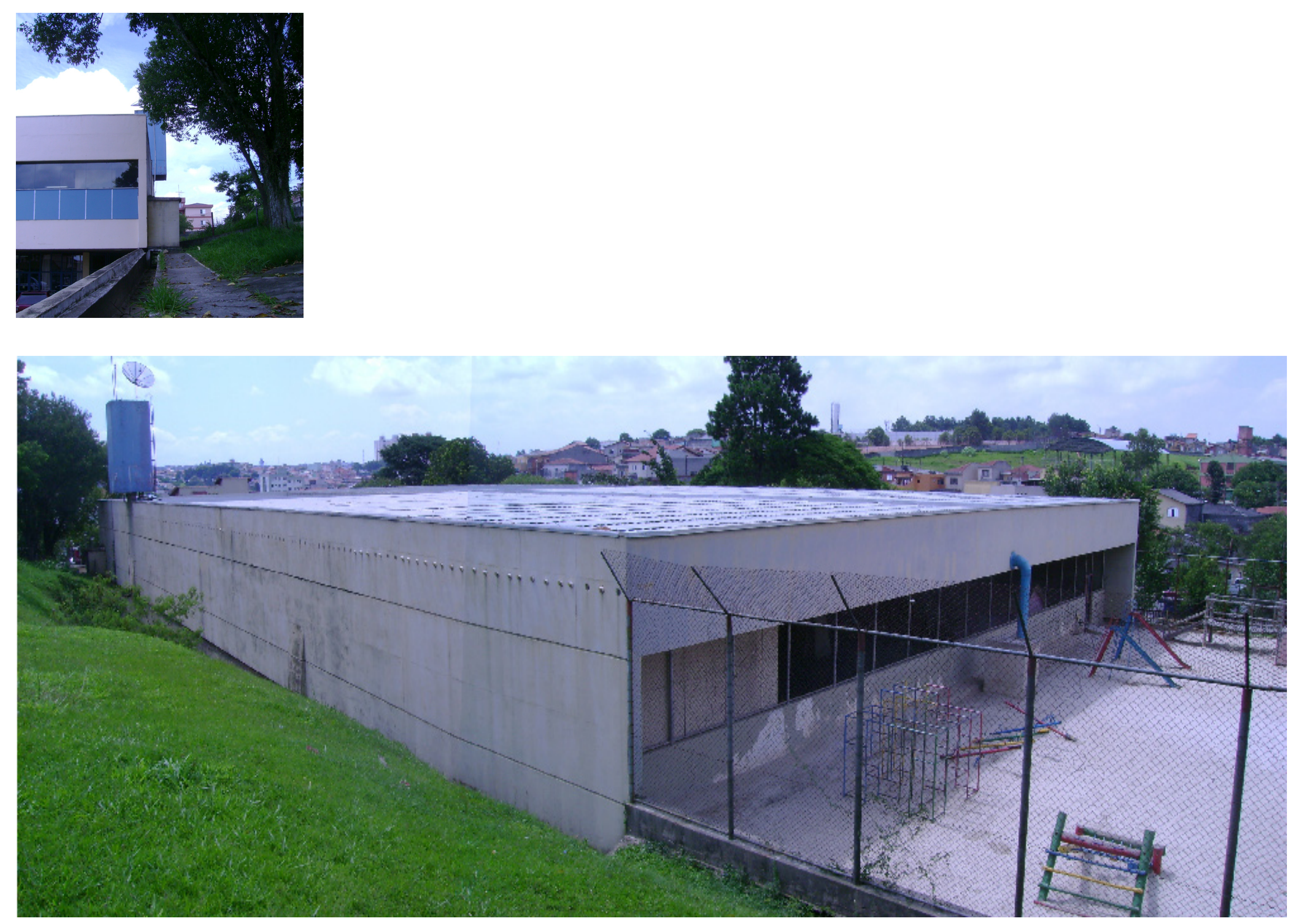


\section{EE Luiza Collaço Queiroz Fonseca / 1966}

Rua Vicente Moreira da Rocha, 44. Vila Ferrazópolis, São Bernardo do Campo, SP

Arquiteto: Ubyrajara Gilioli.

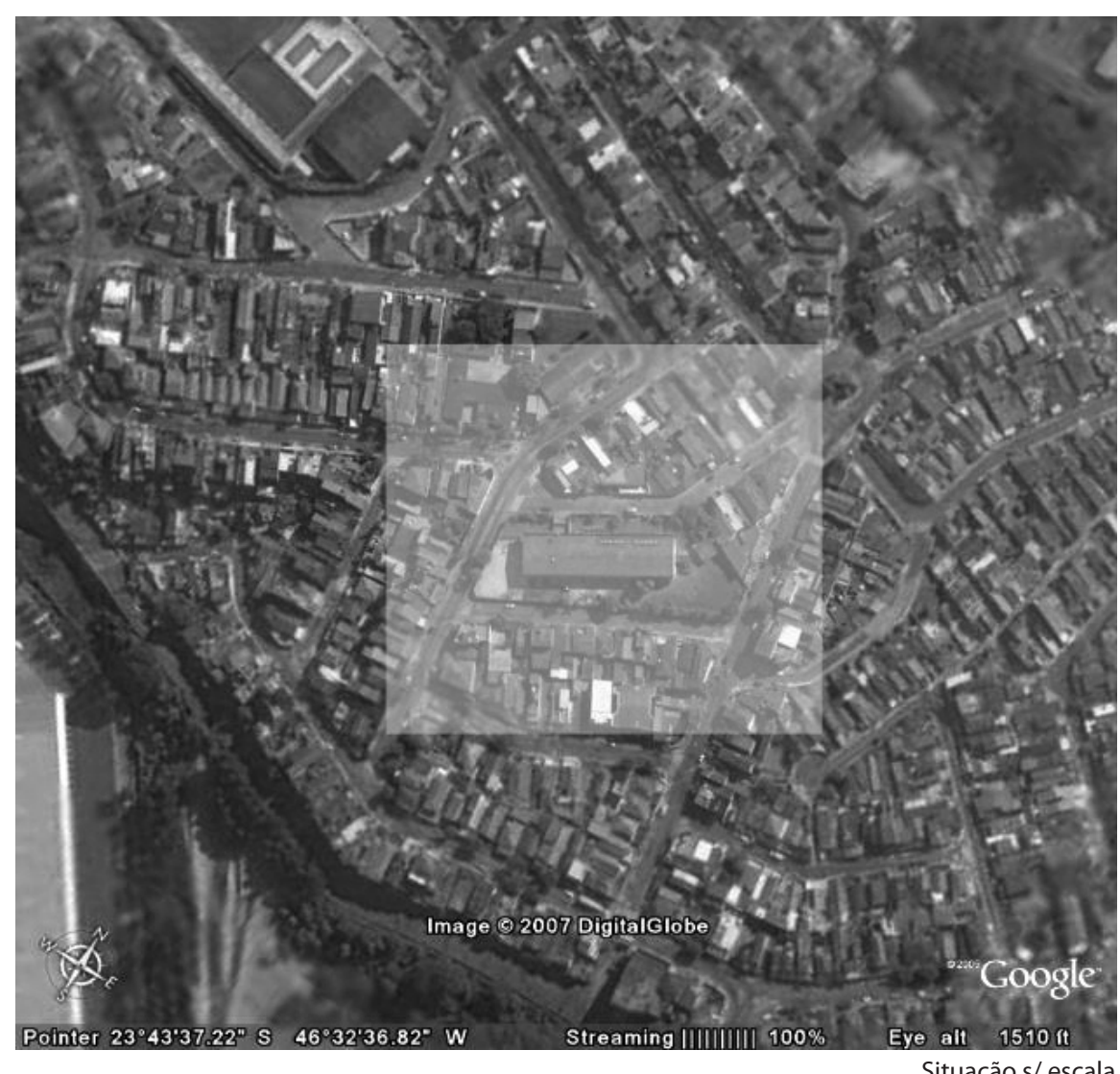



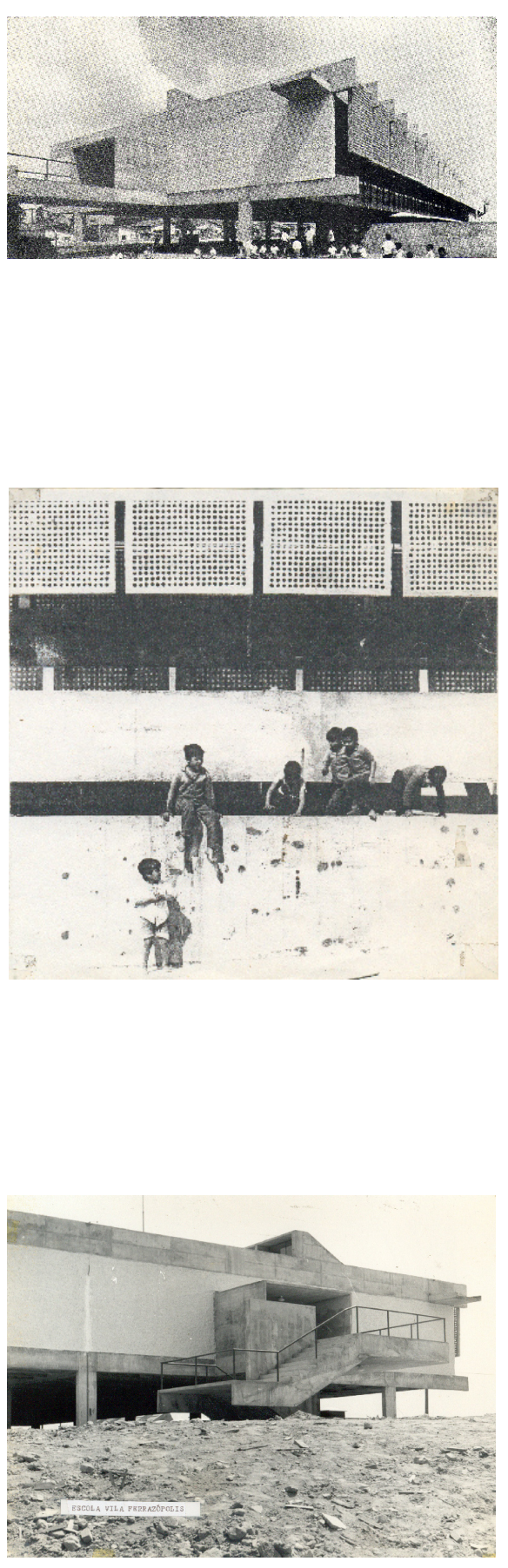

O arquiteto Ubyrajara Gilioli projetou duas escolas na cidade de São Bernardo do Campo para o FECE. Uma na Vila Ferrazópolis e outra na Vila Paulicéia.

Localizada em terreno estreito e praticamente plano, a implantação da escola em Ferrazópolis eleva o bloco didático, reservando ao rés-do-chão o pátio de recreação coberto dos alunos, que é desdobrado em dois níveis: o nível do acesso e o outro, rebaixado em $1.50 \mathrm{~m}$, conectado ao superior por duas generosas escadarias. No nível de acesso situa-se o bloco administrativo e o bloco de serviços, no pavimento inferior.

A estrutura é muito simples, definida por pilares equidistantes que suportam uma laje nervurada, com balanços iguais nos dois sentidos. O módulo estrutural tem um papel fundamental nessa escola sendo definido pela largura das salas de aula $(7.20 \mathrm{~m})$. Todas as outras dimensões são múltiplos ou sub-múltiplos desse módulo. Os caixilhos de vedação das salas são absolutamente iguais, com um módulo de $1.20 \mathrm{~m}$ de largura por $3.00 \mathrm{~m}$ de altura.

O pavimento superior, além de conter as doze salas de aula do primário, abriga duas salas destinadas ao préprimário, tendo anexados a elas o pátio coberto em forma de terraço e os banheiros específicos. Nesse nível, a sala dos professores separa as destinadas ao pré-primário das outras. As salas de aula voltam-se para as ruas de acesso e têm orientações noroeste e sudeste. São muito bem iluminadas e arejadas. As da face noroeste são protegidas por placas pré-moldadas de concreto, afixadas nos avanços das vigas de cobertura. Através de aberturas zenitais em forma de lanternins, elas recebem luz sudeste, o que possibilita que as salas em ambas orientações tenham qualidades semeslhantes, mesmo voltadas para faces opostas

As aberturas zenitais em forma de domus, os caixilhos sobre as paredes divisórias entre as salas (com ventilação permanente) e os bancos dispostos ao longo de sua extensão garantem à circulação horizontal uma qualidade especial, na medida em que pode ser utilizada também como lugar de estar. Duas escadas, uma maior e coberta e outra menor e descoberta, conectam os pavimentos. A maior situa-se exatamente no eixo da "praça" de acesso da escola e a outra, na extremidade nordeste do edifício, como uma circulação alternativa entre o nível das salas de aula e o pátio. Essa diversidade da circulação vertical dinamiza o espaço ao oferecer diferentes possibilidades de percurso. 

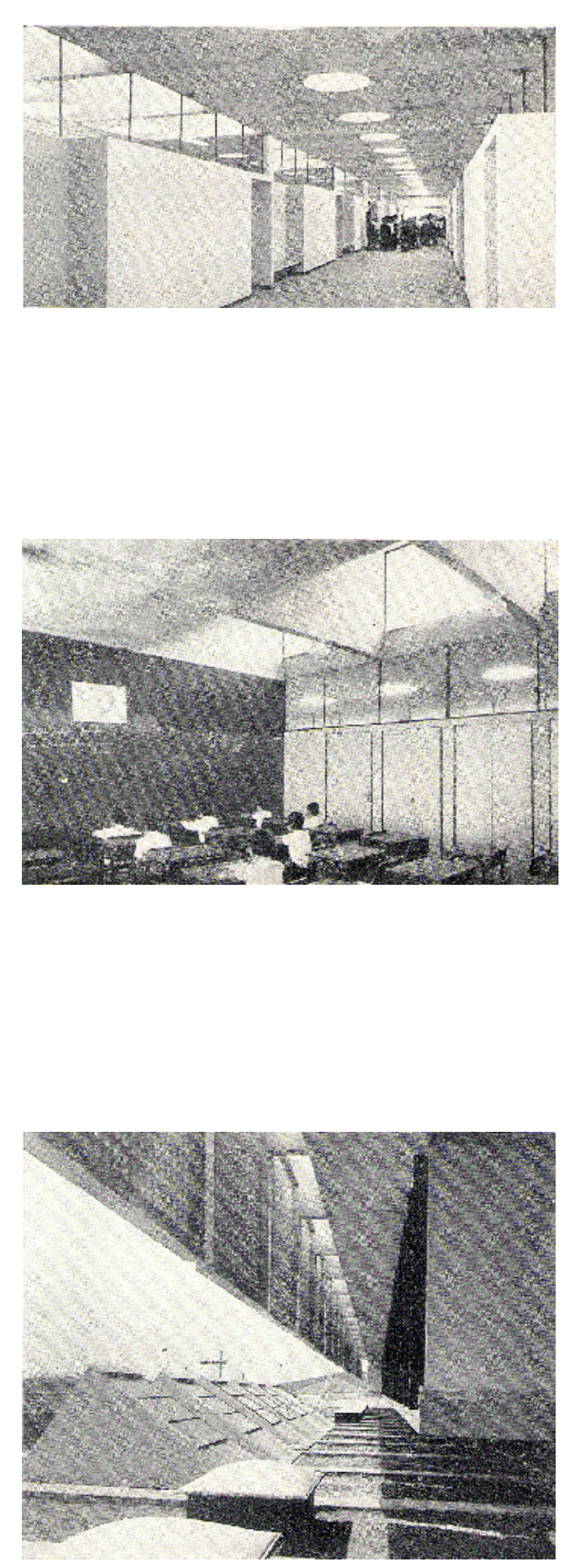

De acordo com Gilioli (informação verbal)', a maioria dos arquitetos envolvidos na produção escolar desse período eram filiados ao Partido Comunista. Liderados por Vilanova Artigas, buscavam em seus projetos e obras, localizadas via de regra em áreas extremamente carentes de equipamentos públicos, propor o edifício escolar como elemento de ordenação urbana.

Os aspectos construtivos também relacionavam-se a esse ideário, buscavam representar essa ideologia: com a utilização da estrutura em concreto armado sem revestimento, das tubulações aparentes, das alvenarias tratadas de maneira a destacar-se da estrutura principal, os arquitetos trariam para a obra uma transparência didática do seu processo de construção. Como se o prédio em si pudesse ensinar aos futuros alunos da escola a própria arquitetura proposta.

Muitas alterações contribuíram para a descaracterização das intenções originais do projeto para essa escola. A principal delas foi o fechamento dos "pilotis" com muros, grades e elementos vazados, transformando o pátio de recreação num lugar escuro e sem comunicação, nem visual, muito menos física com o espaço externo. $O$ avesso daquilo que fora proposto por Gilioli, que assim resume essa triste passagem: "Transformaram a escola num presídio!" 2 

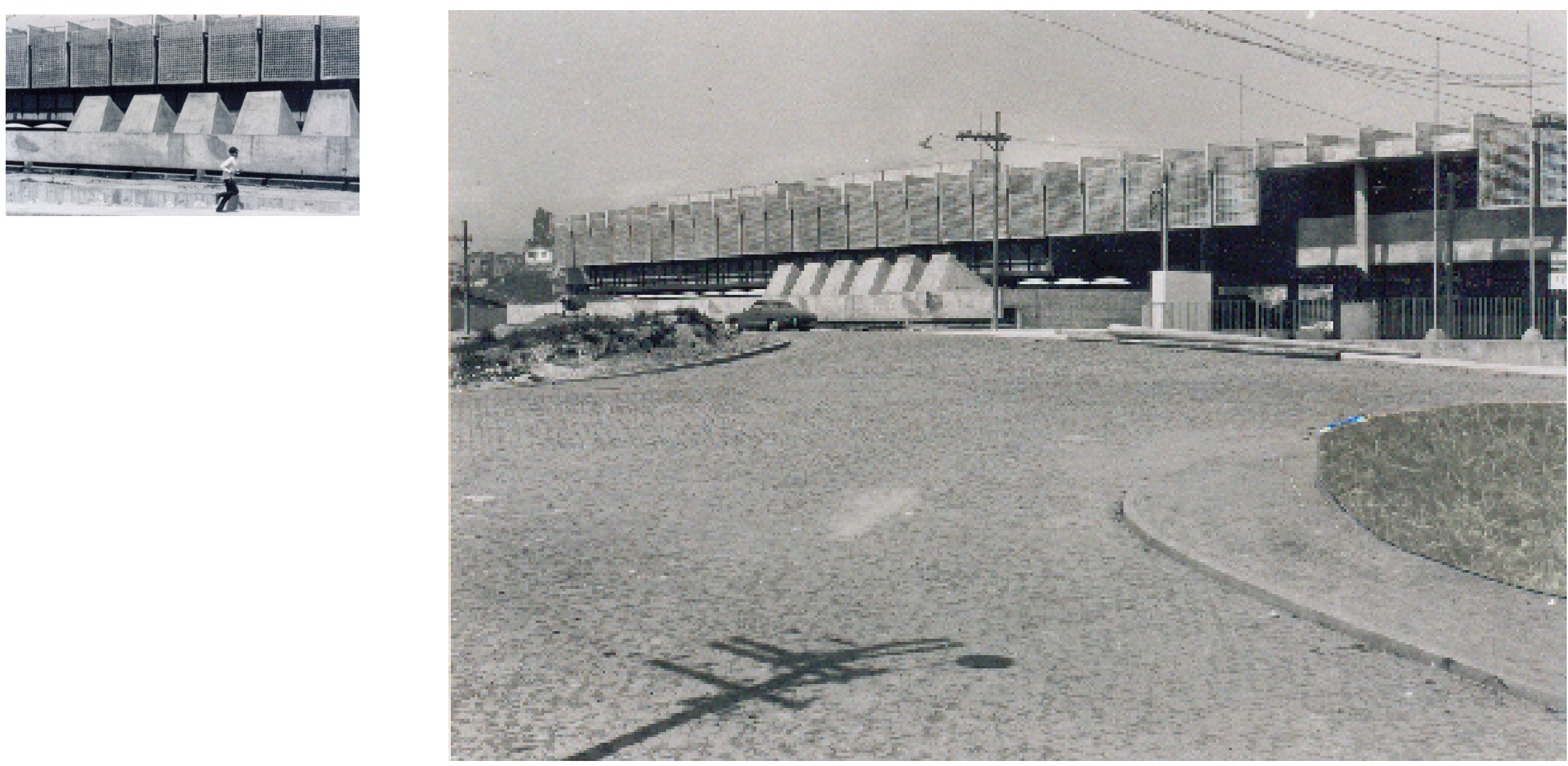


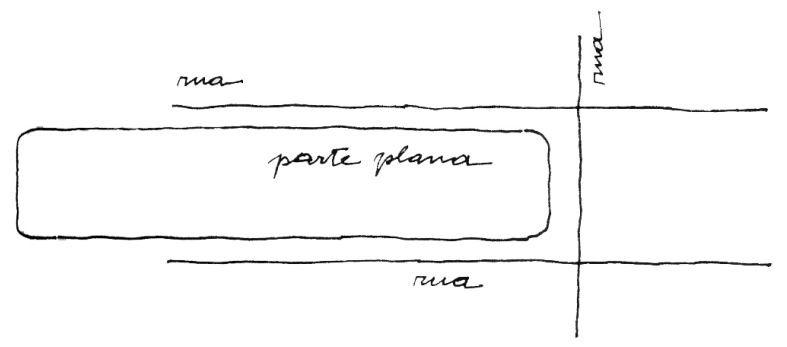

des. 1

Croquis do arquiteto Ubyrajara Gilioli
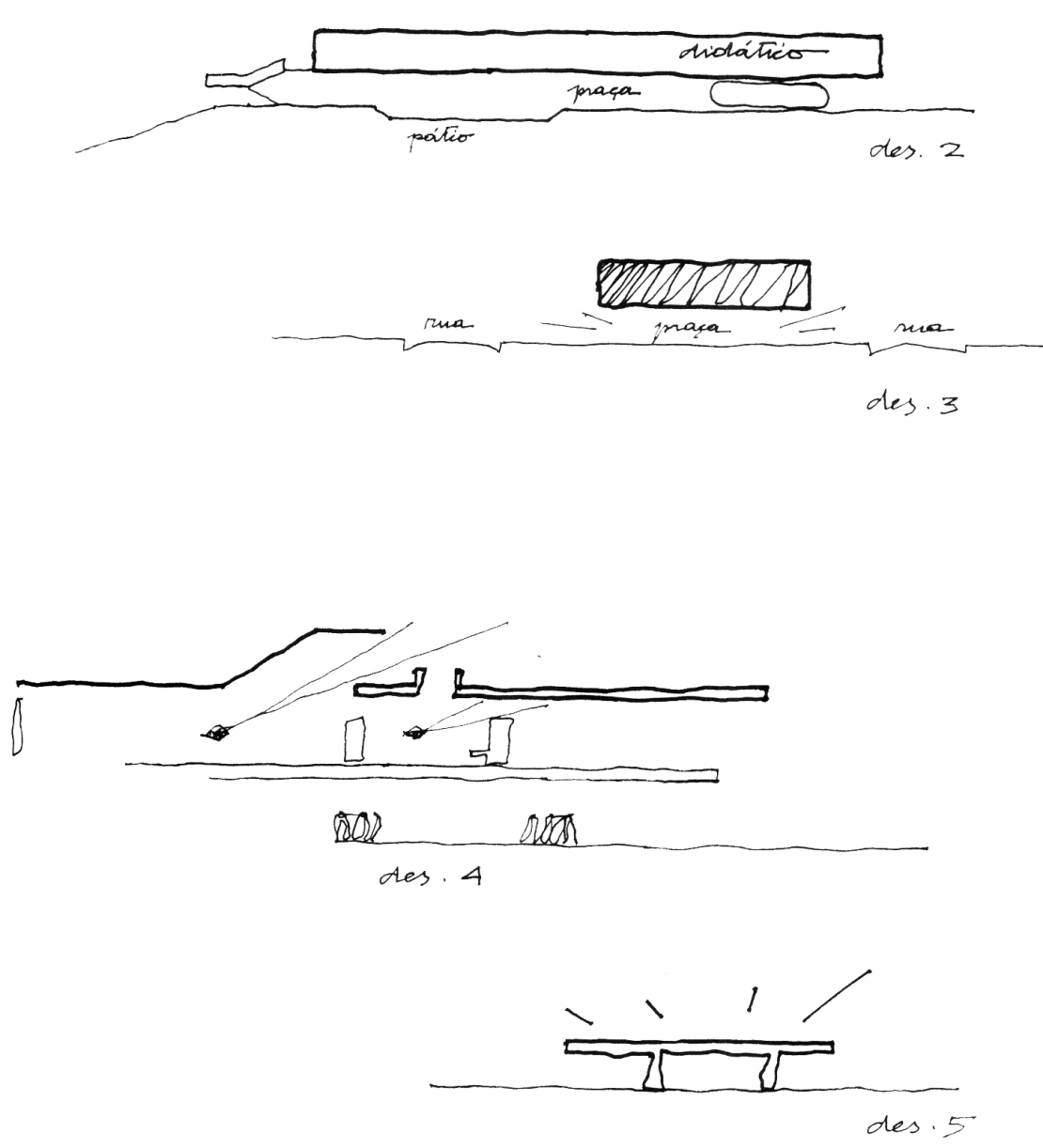


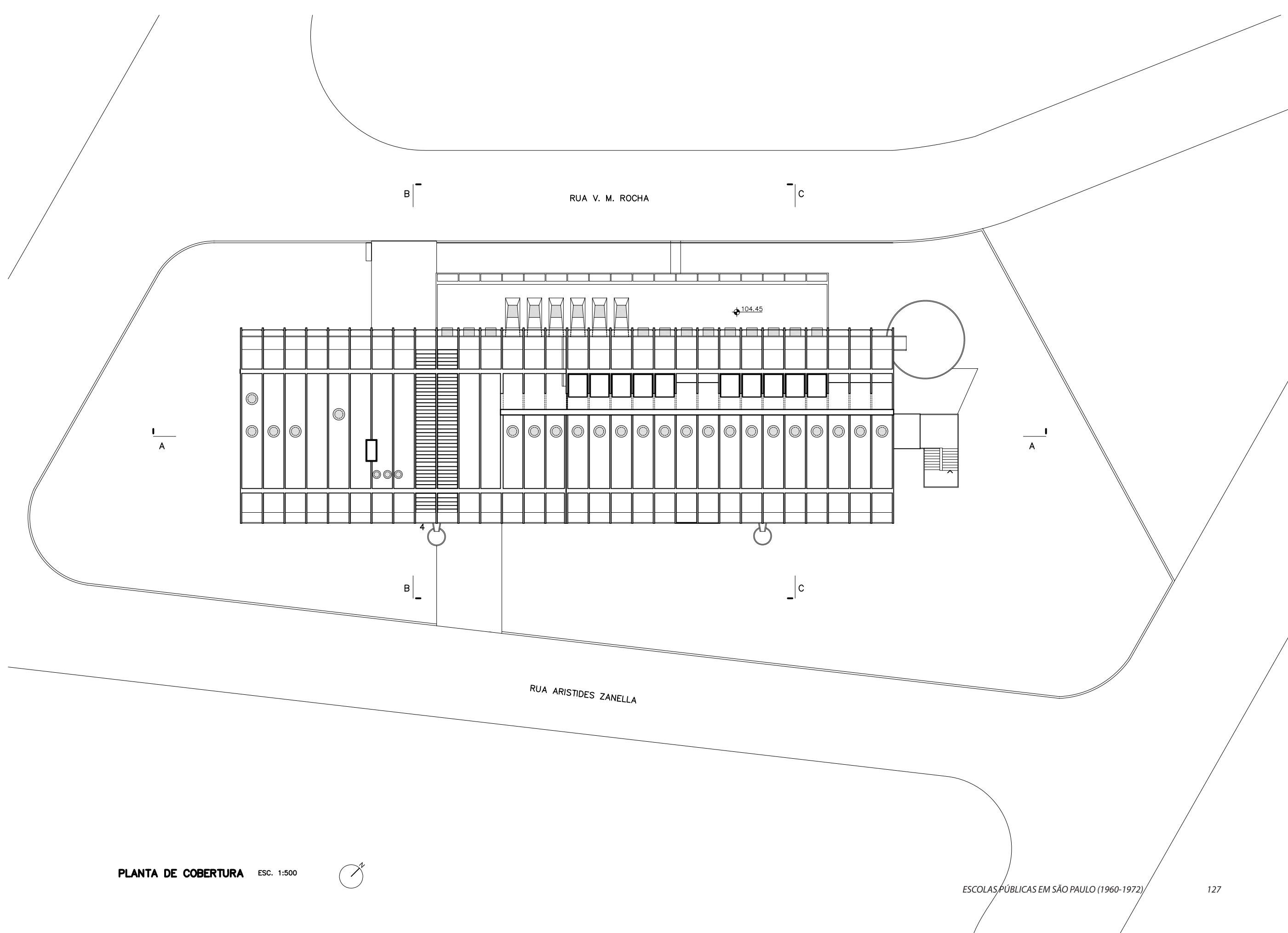




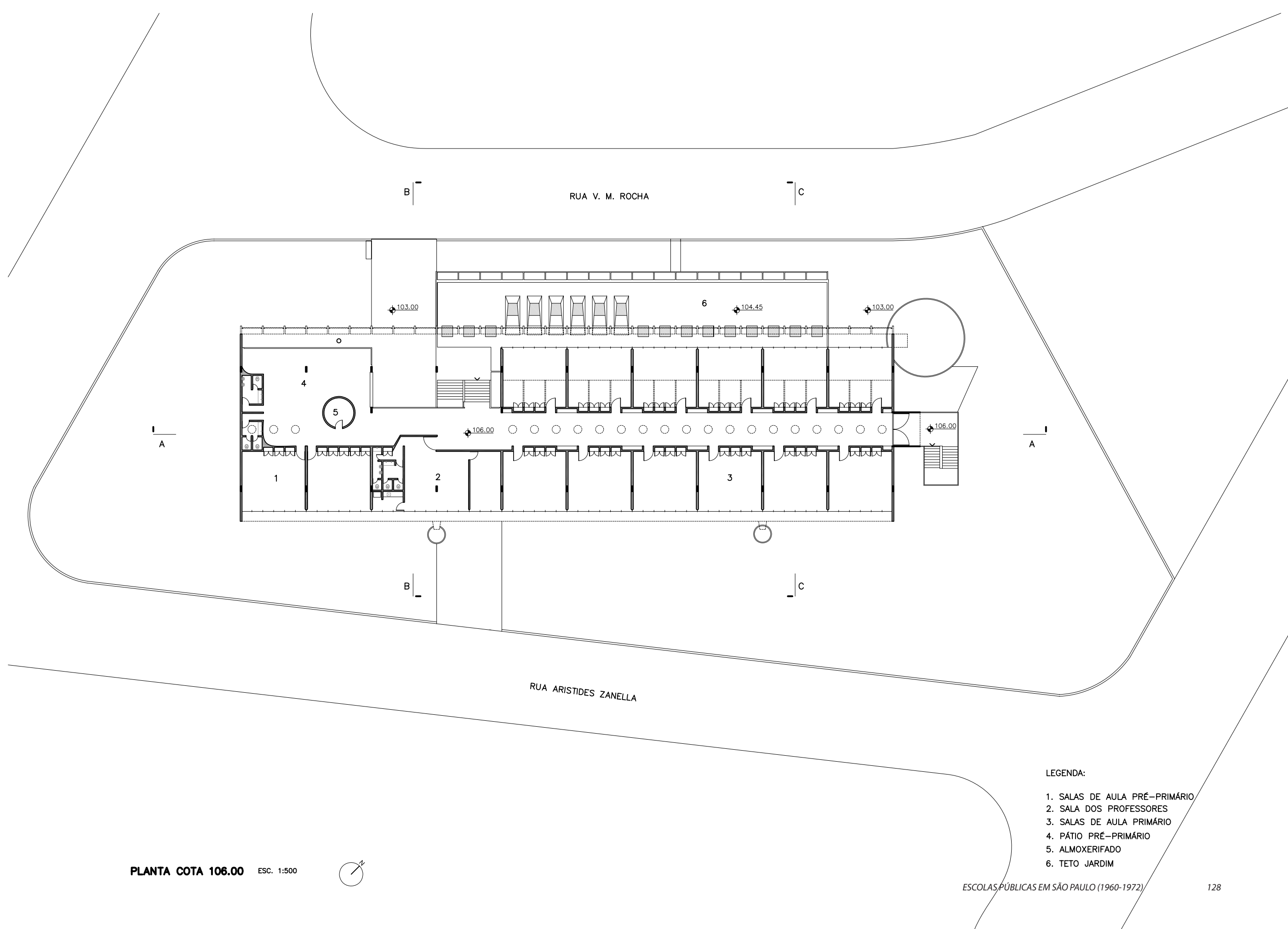




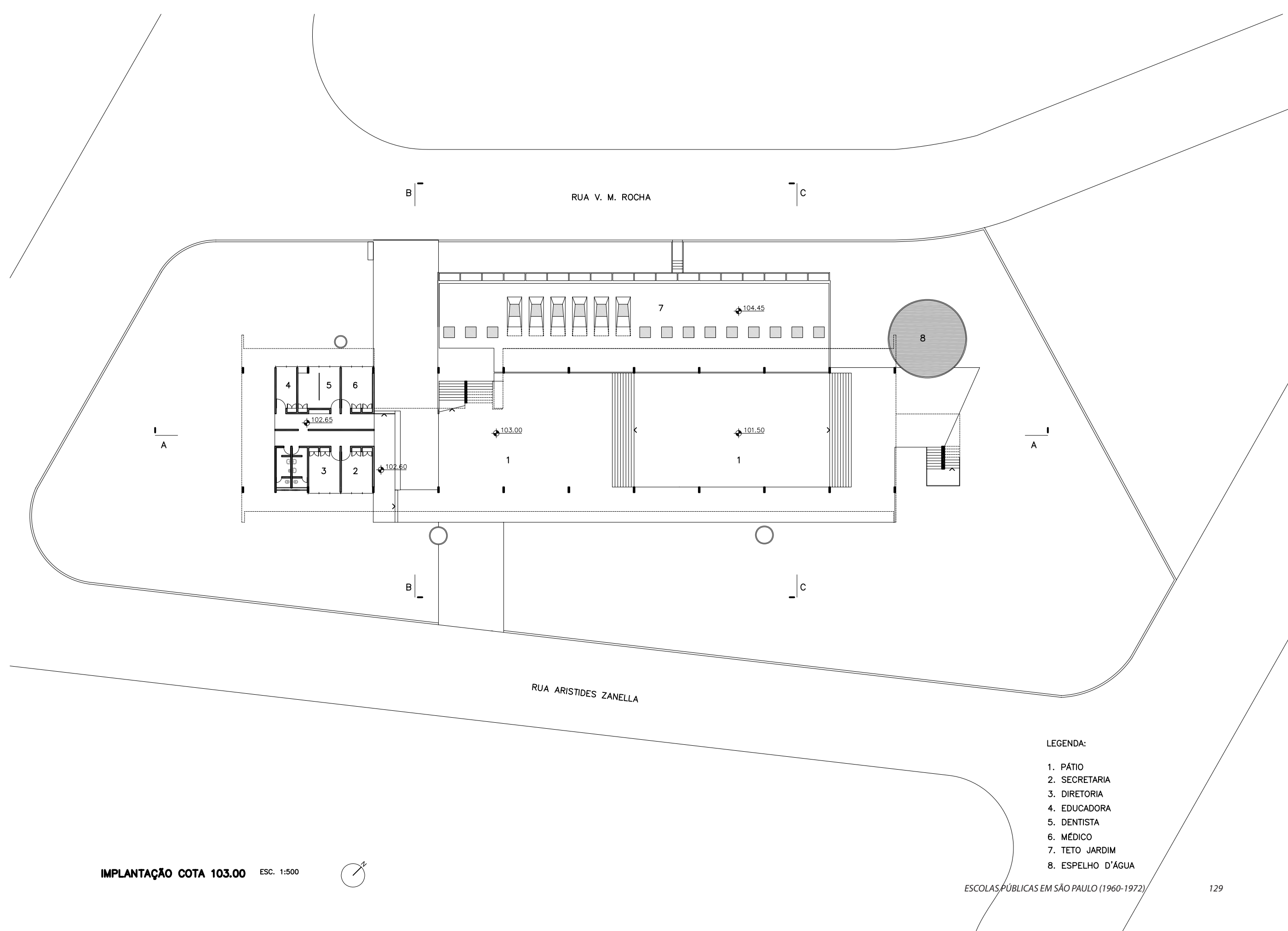




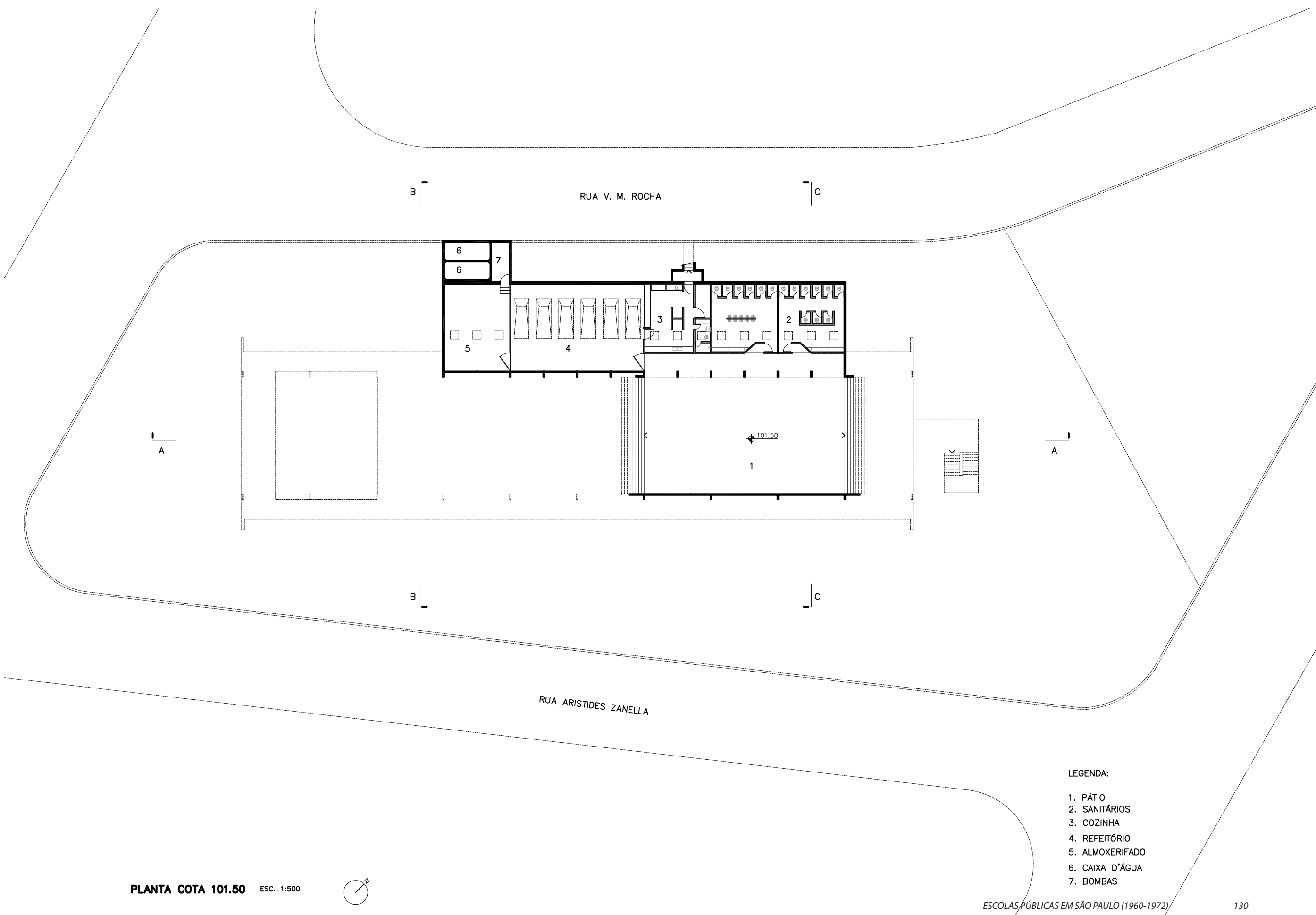




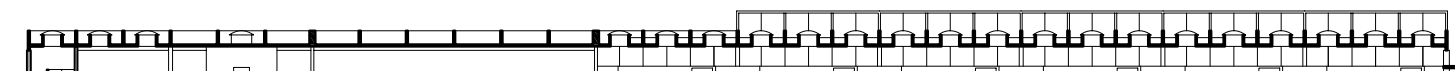

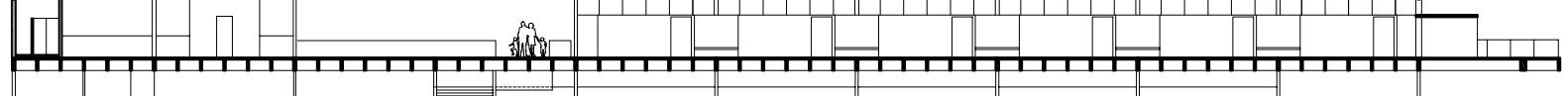

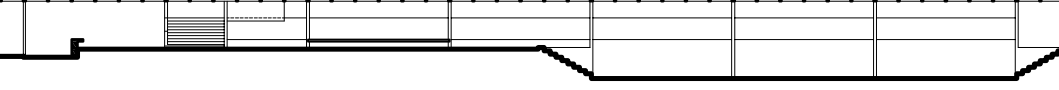

CORTE AM ESC. 1:500

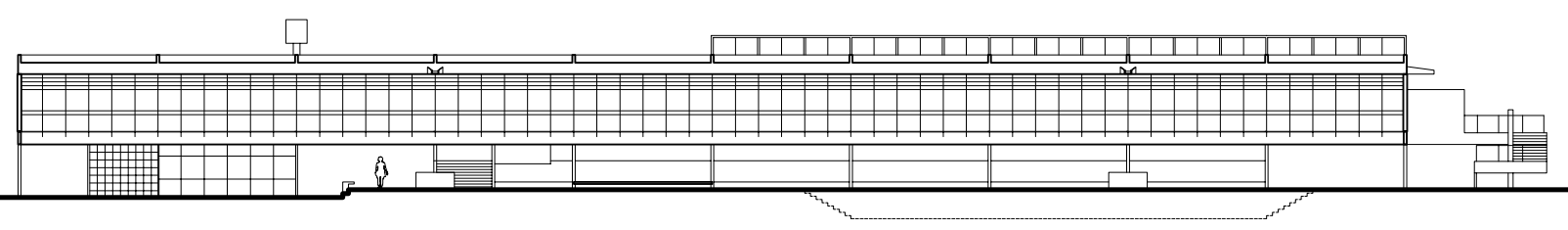

ELEVAGAO SUDESTE ESC. 1:500

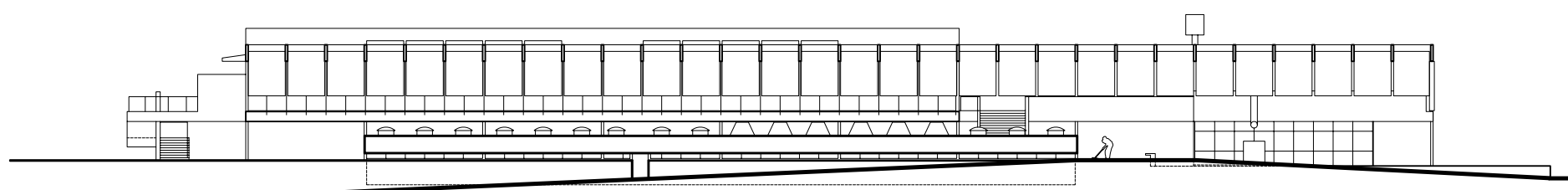

ELEVACAOAO NOROESTE ESC. 1:500 

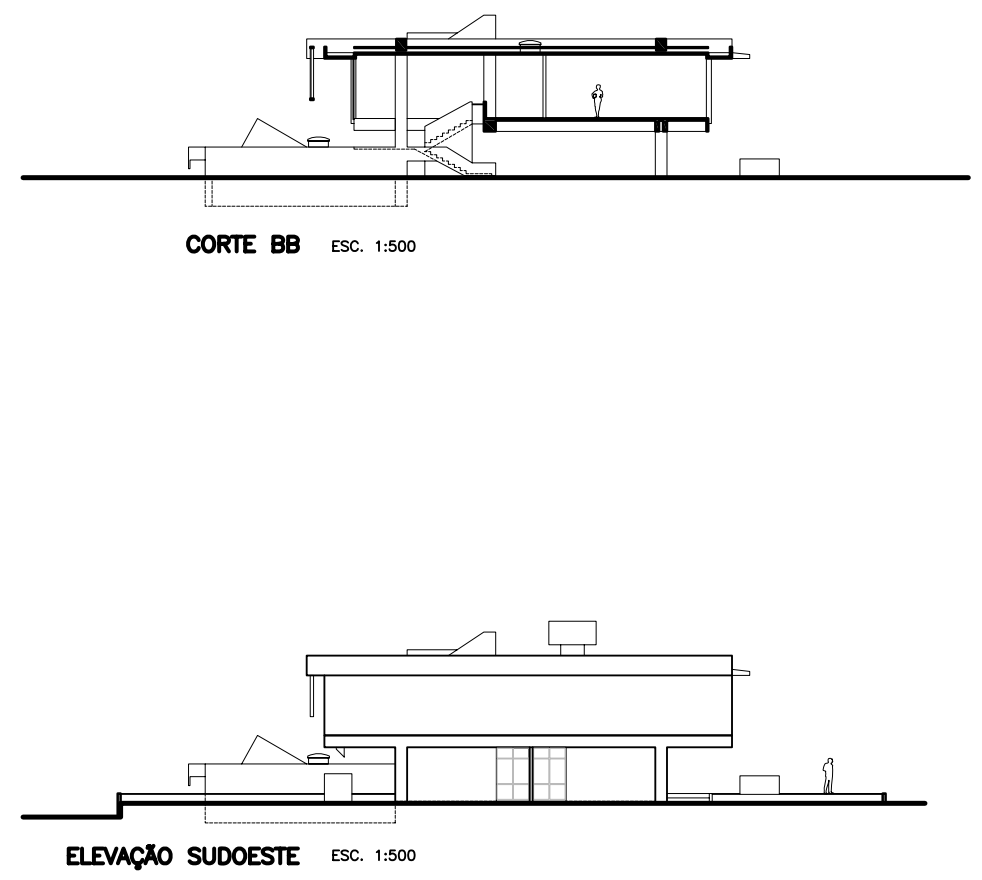
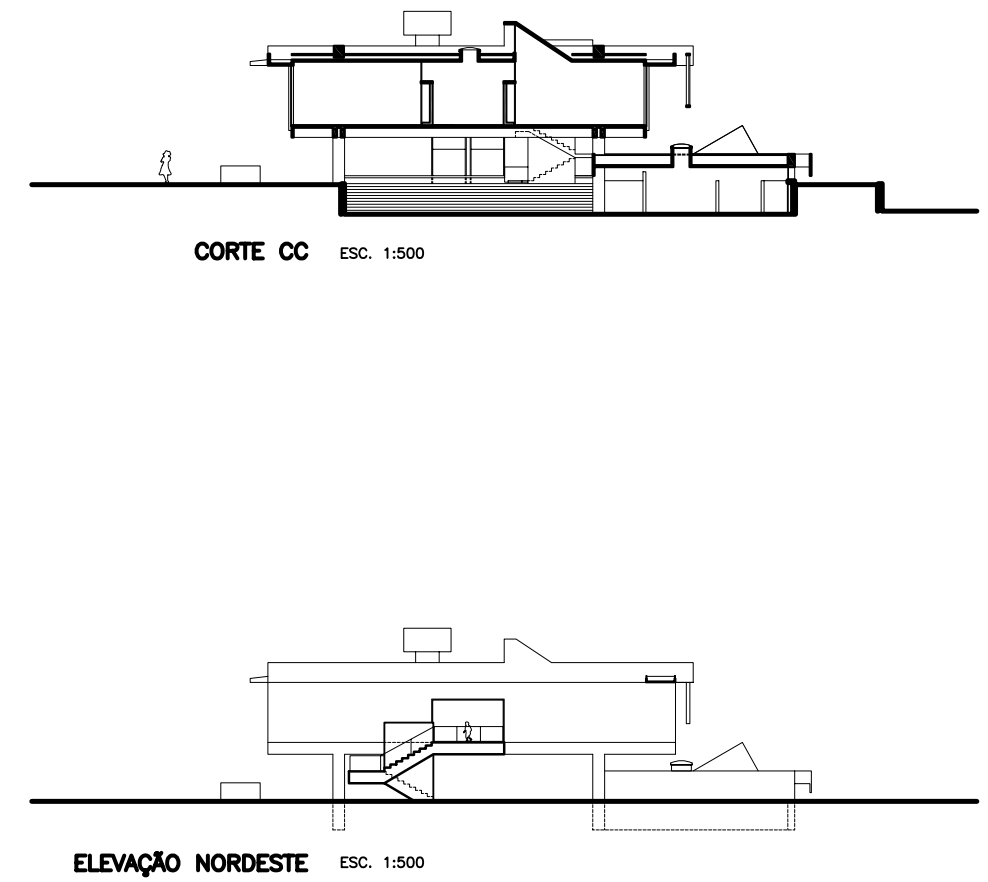

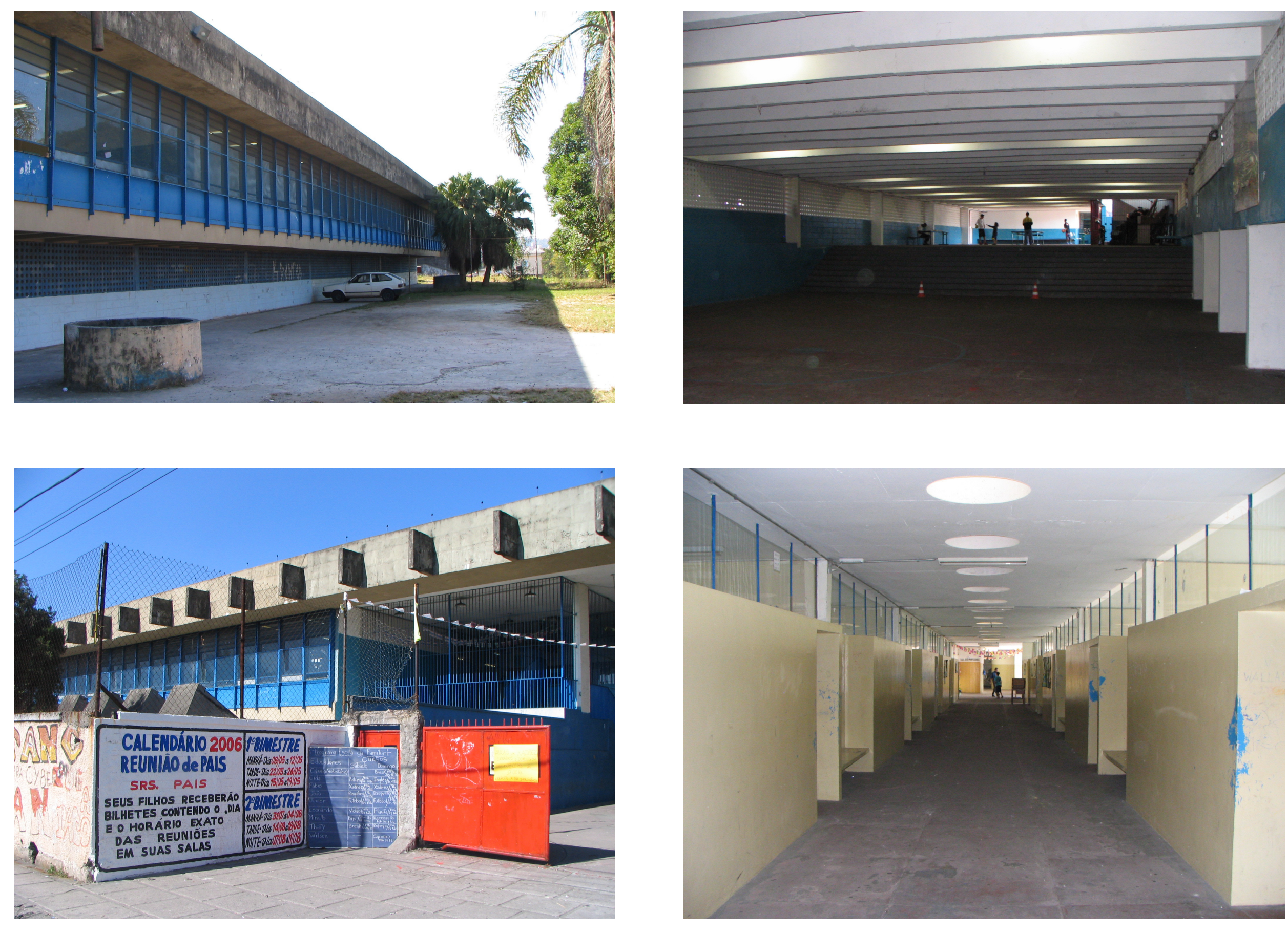


\section{EE Fausto Cardoso Figueira de Mello / 1967}

Rua Francisco Alves, 580, Vila Paulicéia, São Bernardo do Campo, SP

Arquiteto: Ubyrajara Gilioli.

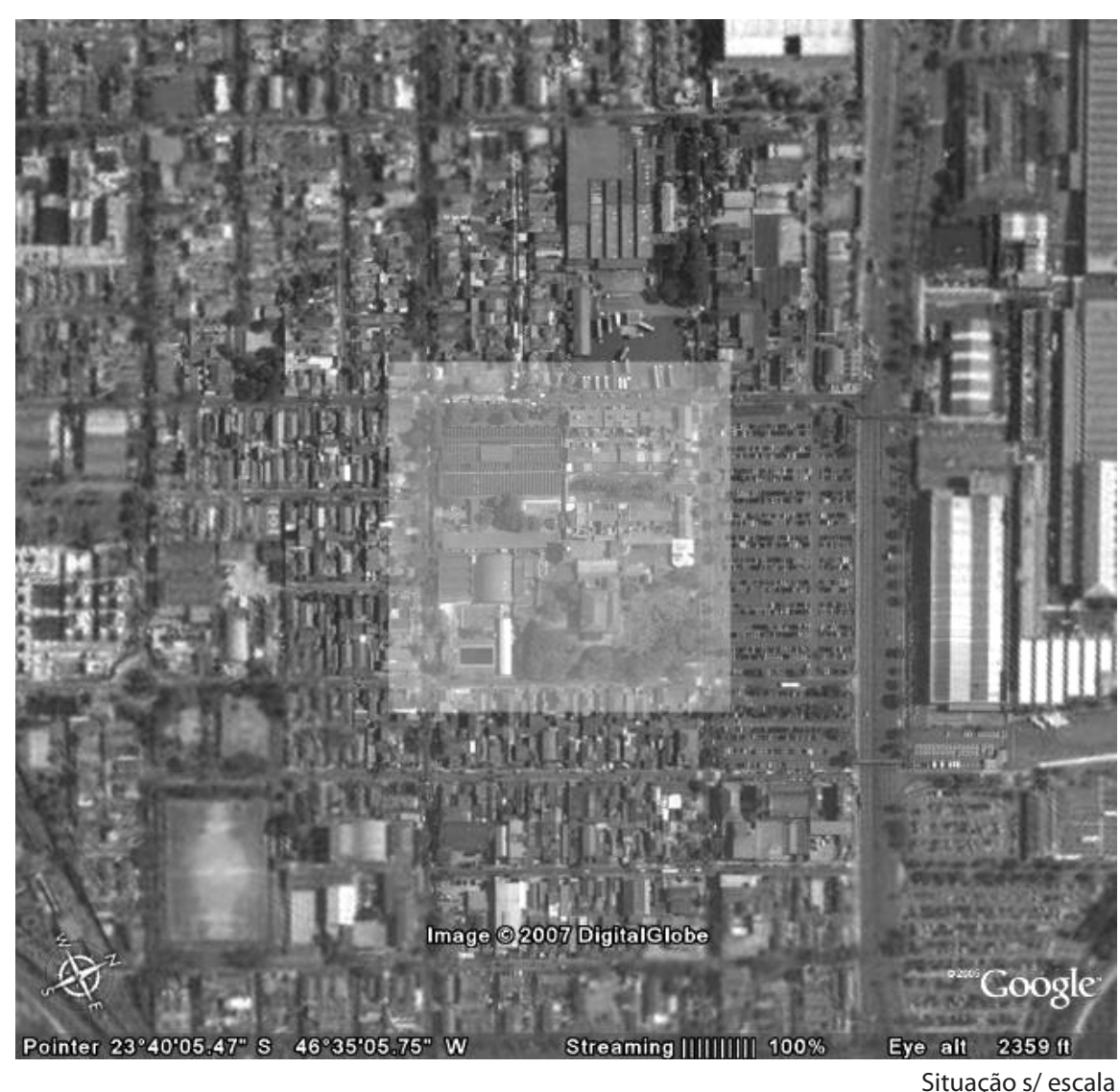



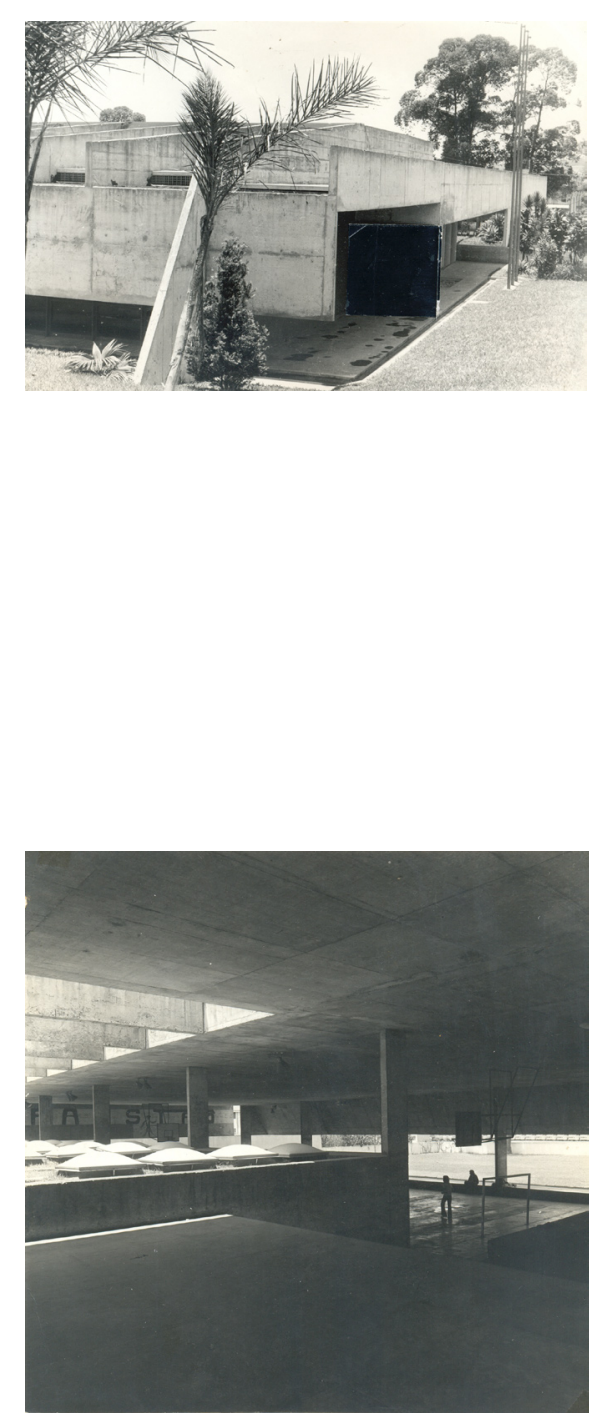

Em conformidade com a intenção de criar um centro de referência urbana, essa escola, projetada dois anos depois que a de Ferrazópolis, talvez seja a sua maior realização de Ubyrajara Gilioli.

Localizada em Vila Paulicéia, bairro operário do município de São Bernardo do Campo, a escola situa-se em terreno extenso e desnivelado. Foi implantada na porção mais alta do sítio, de modo a destacar-se em relação ao entorno e, ao mesmo tempo, liberar as visuais para a paisagem da cidade. Sua ampliação foi prevista no sentido longitudinal de seu corpo, mantendo o fundo de vale desocupado, como um parque fluvial (lugar de práticas esportivas e lazer) imediatamente vinculado ao pátio de recreação da escola.

Uma única cobertura abriga as instalações da escola, divididas em três faixas longitudinais. A primeira contém o bloco didático, doze salas de aula voltadas para a mesma orientação (face noroeste), em nível com o jardim externo e protegidas da incidência do sol por uma placa horizontal contínua de $92 \mathrm{~m}$ de comprimento, em concreto armado. Além da luz noroeste, as salas de aula recebem luz da face sudeste através de lanternins em toda sua extensão. Bem como a escola anterior (EE Luiza Collaço Queiroz Fonseca), o módulo das salas de aula tem 7.20m de largura e os caixilhos, idênticos, vão do piso ao teto e de parede a parede. A circulação também tem as mesmas qualidades que a escola anterior: generosa, ilumidada e ventilada por domus, com bancos ao longo de seu comprimento e luz nas extremidades.

A faixa intermediária abriga o bloco administrativo, o auditório, os laboratórios e as salas-ambiente na face nordeste. A outra faixa, um pavimento abaixo, agrega o pátio de recreação, quadra poliesportiva e as funções de apoio, cantina, banheiros, vestiários, depósitos, médico, dentista e, em destaque, como que flutuando sobre o pátio de recreação, o grêmio dos alunos.

A cobertura da escola merece destaque: plana e impermeabilizada em sua maior parte, configurada por vigas a cada $2.40 \mathrm{~m}$, constituindo a cada três módulos o vão da estrutura que ora inclina-se em forma de sheds para permitir a incidência da luz sudeste nos ambientes, salas de aula, administração e laboratórios; ora "falha", formando uma grande extensão de pérgula que permite a iluminação e ventilação tanto dos pátios como dos ambientes anteriormente listados; ora sobreleva-se, no caso do auditório, permitindo uma altura maior no pé-direito deste e, ao mesmo tempo possibilitando o recebimento de luz noreoeste-sudeste e ventilação cruzada e uma altura condizente com o uso proposto. Para o escoamento das águas pluviais o arquiteto fez uso de calhas, buzinotes, 

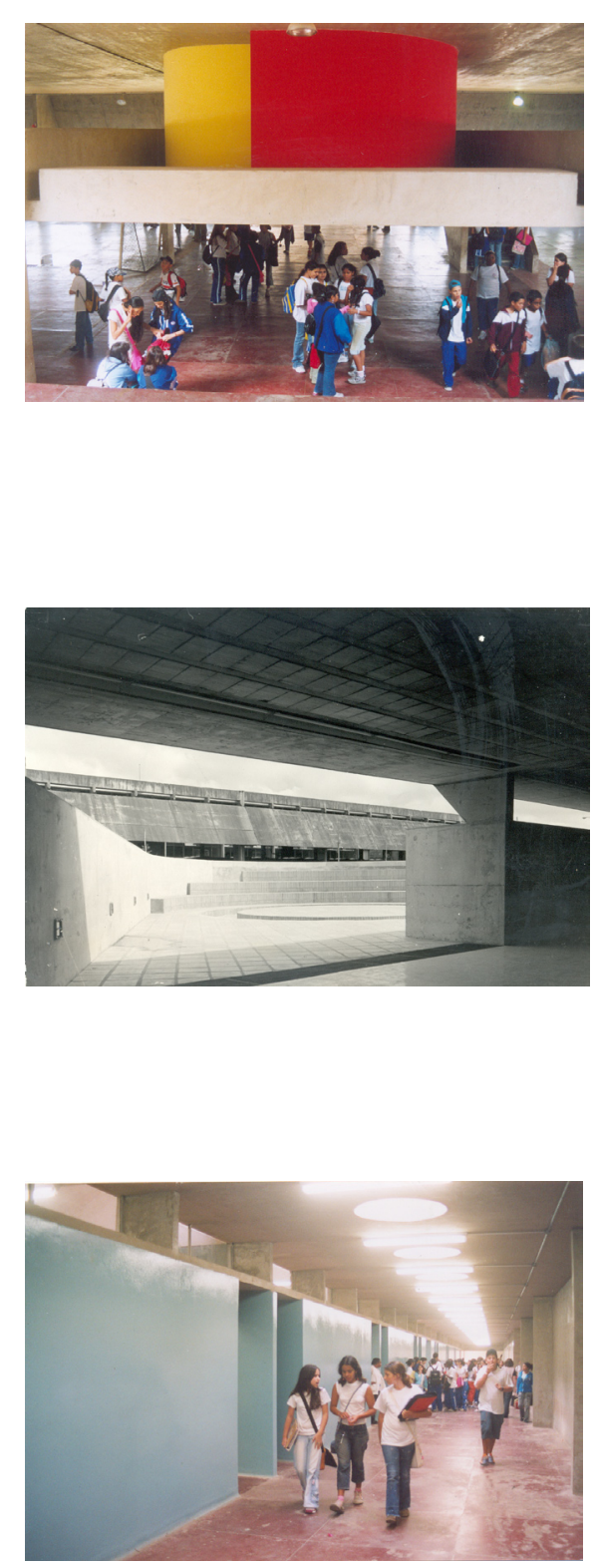

furos, dutos verticais de escoamento, caixas de captação, gárgulas, lajes jardim, etc. Uma gama de elementos do repertório moderno que puderam ser utilizados em função da grande superfície de laje.

Anos mais tarde, mais precisamente em 1975, a escola foi ampliada e o quadro encontrado era muito diferente do imaginado em princípio pelo arquiteto: o terreno havia sido substancialmente reduzido. Por esse motivo, a ampliação teve que ser pensada de outra maneira. Segundo descrição de Gilioli (1995):

“O novo prédio projetado fundamentou-se nas seguintes premissas: 1.Manutenção das visuais para a cidade desde o interior do primeiro bloco (questão dos níveis de locação); 2.Disposição interna dos espaços de forma oposta a do primeiro bloco, ou seja, com as áreas de jogos e lazer voltadas para cima, criando um grande espaço central em aberto;

3.Criação de uma arena ao ar livre em meio a esse espaço; 4.O teto curvo do novo prédio, trazendo luz pelo alto e desde a praça para o ambiente protegido as aulas; 5.A entrada auxiliar pela praça, juntando a escola, a praça e a comunidade”.

Recentemente as escolas foram restauradas e encontram-se em bom estado de conservação. A entrada pela praça prevista foi fechada e o auditório, paradoxalmente, não foi restaurado e fica permanentemente fechado. Um triste fato para uma escola que conta com um ambiente dessa importância.

GILIOLI, Ubyrajara. Arquitetura e Lugar. 1995. Tese de Doutorado- Faculdade de Arquitetura e Urbanismo da Universidade de São Paulo (FAUUSP), São Paulo, p. 101-102. 

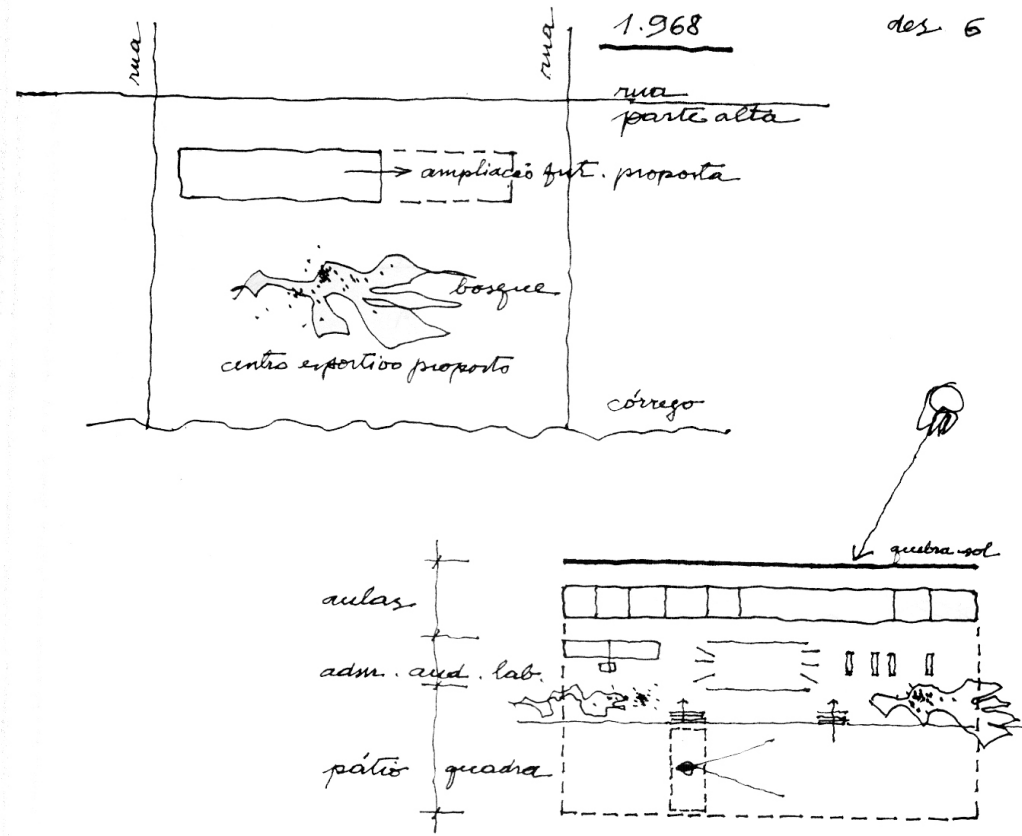

des 7

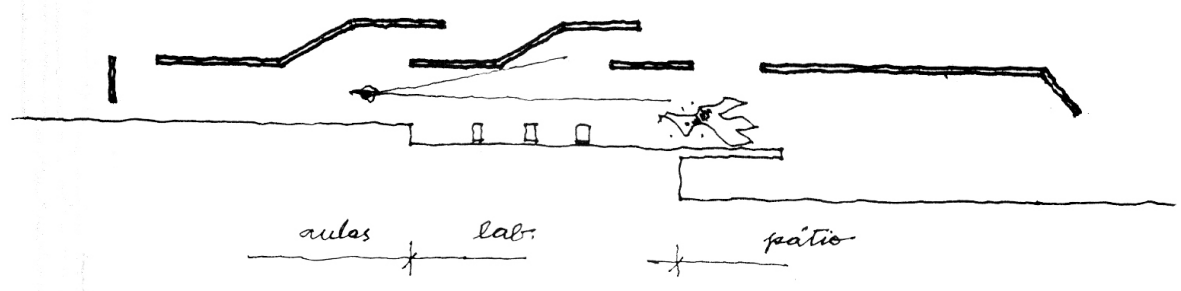

des 8

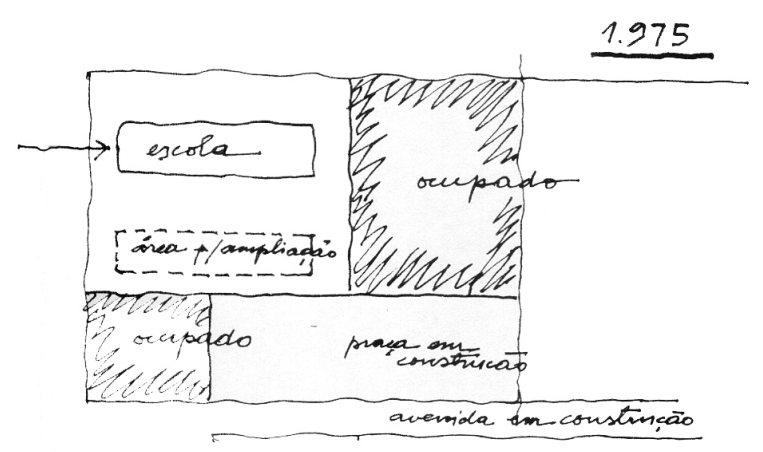

des 9
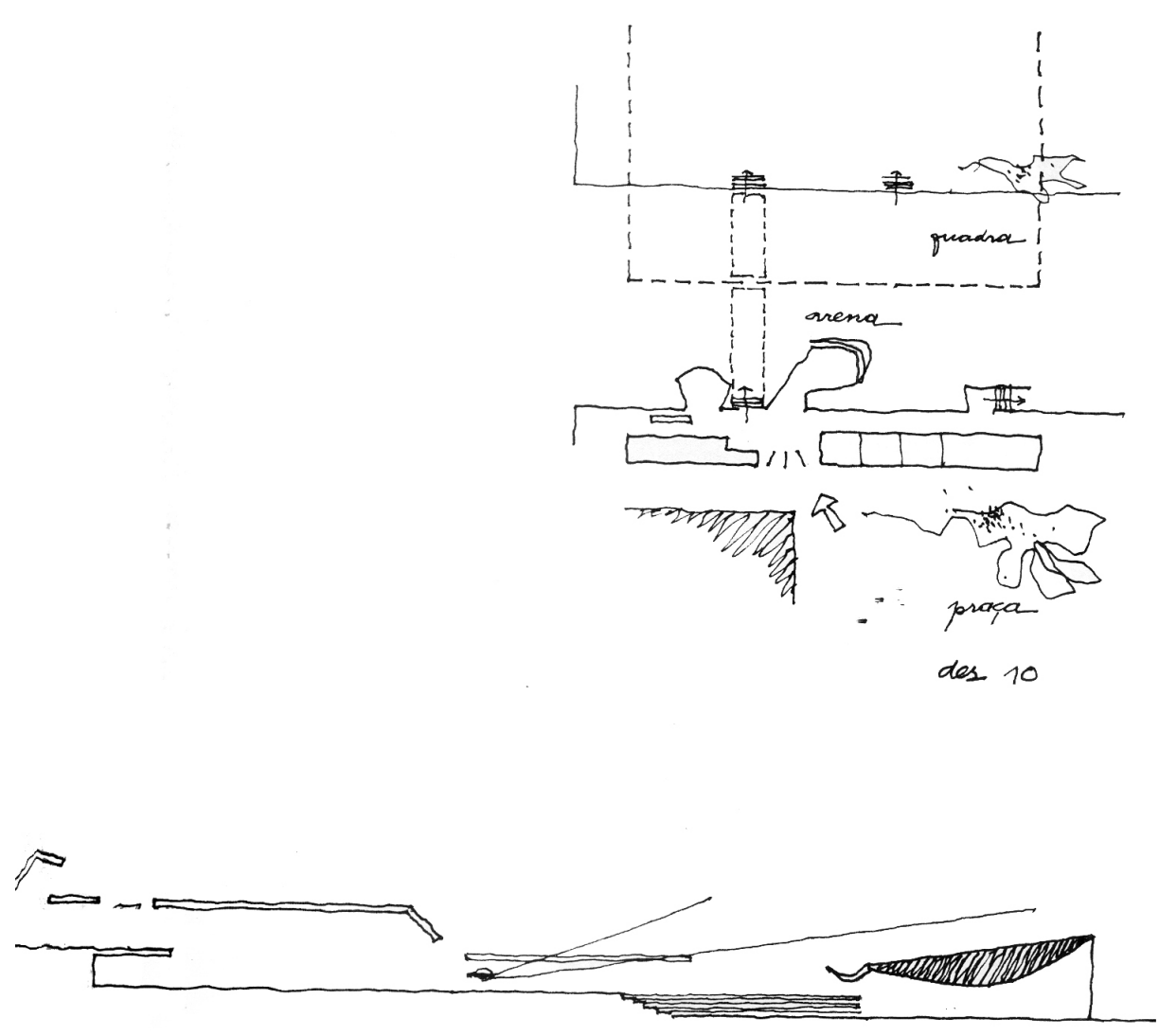

curena

Croquis do arquiteto Ubyrajara Giliol

ESCOLAS PÚBLICAS EM SÃO PAULO (1960-1972)

137 

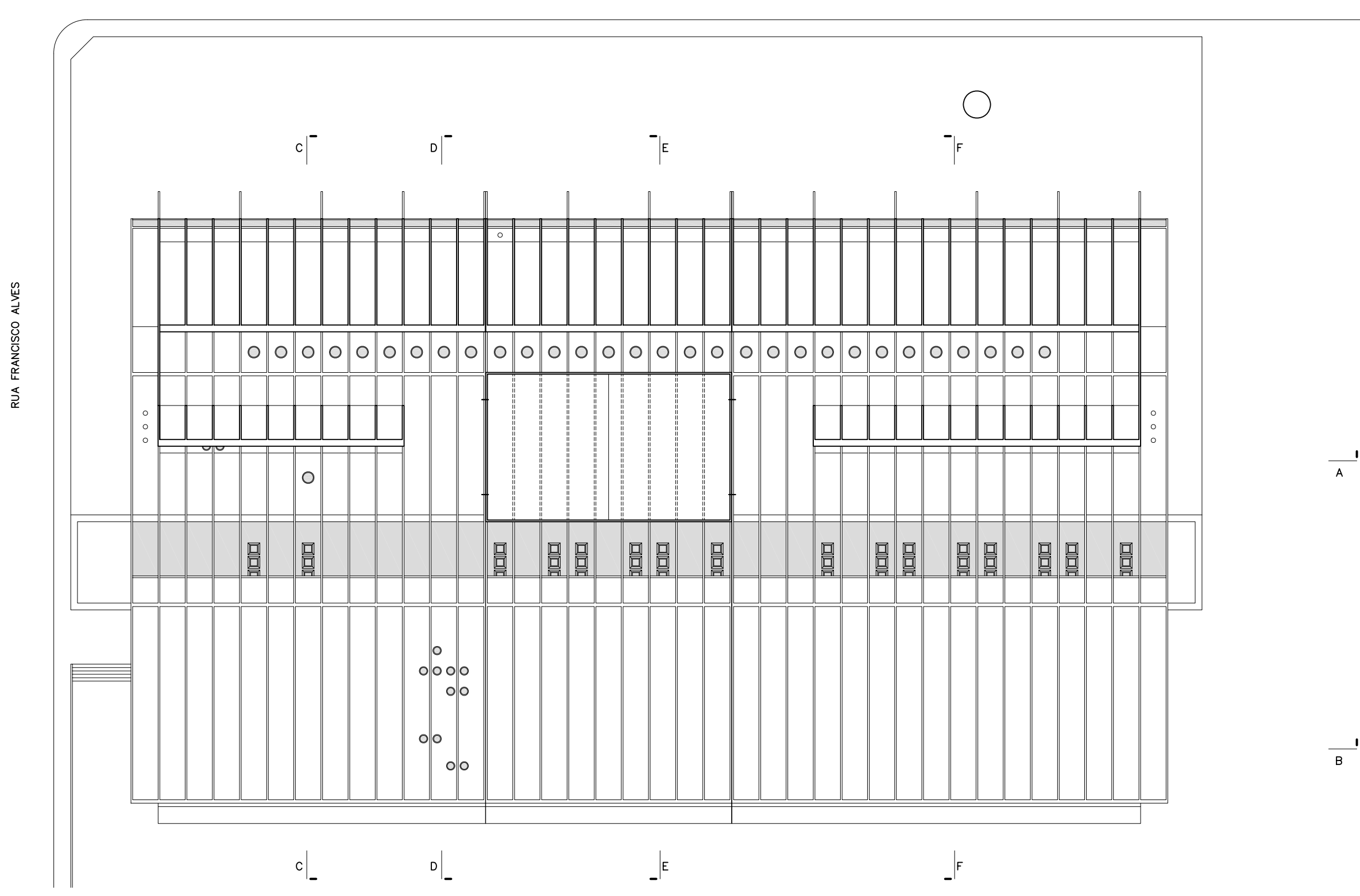

PLANTA DE COBERTURA ESC. 1:500 

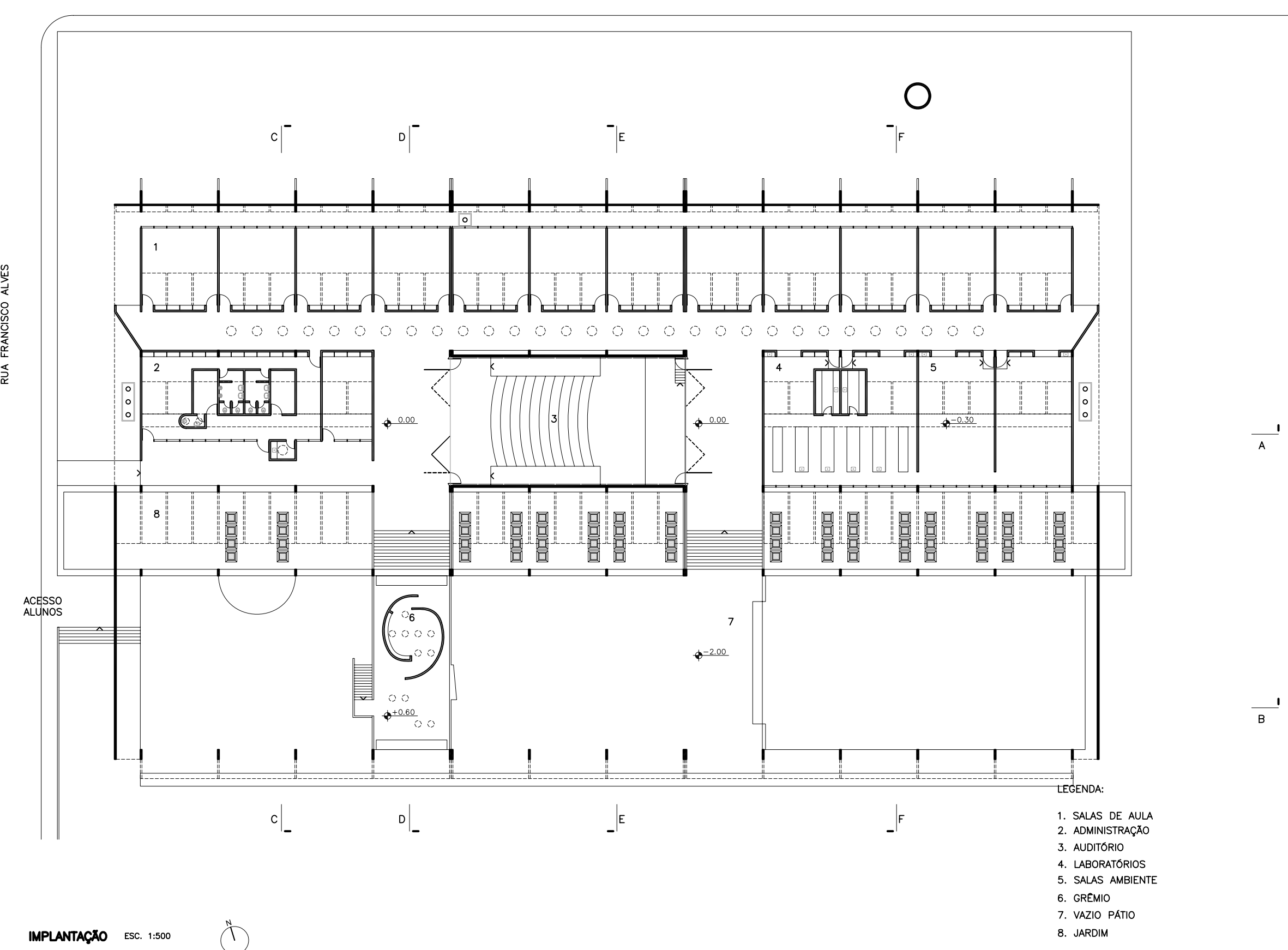


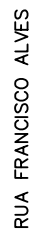
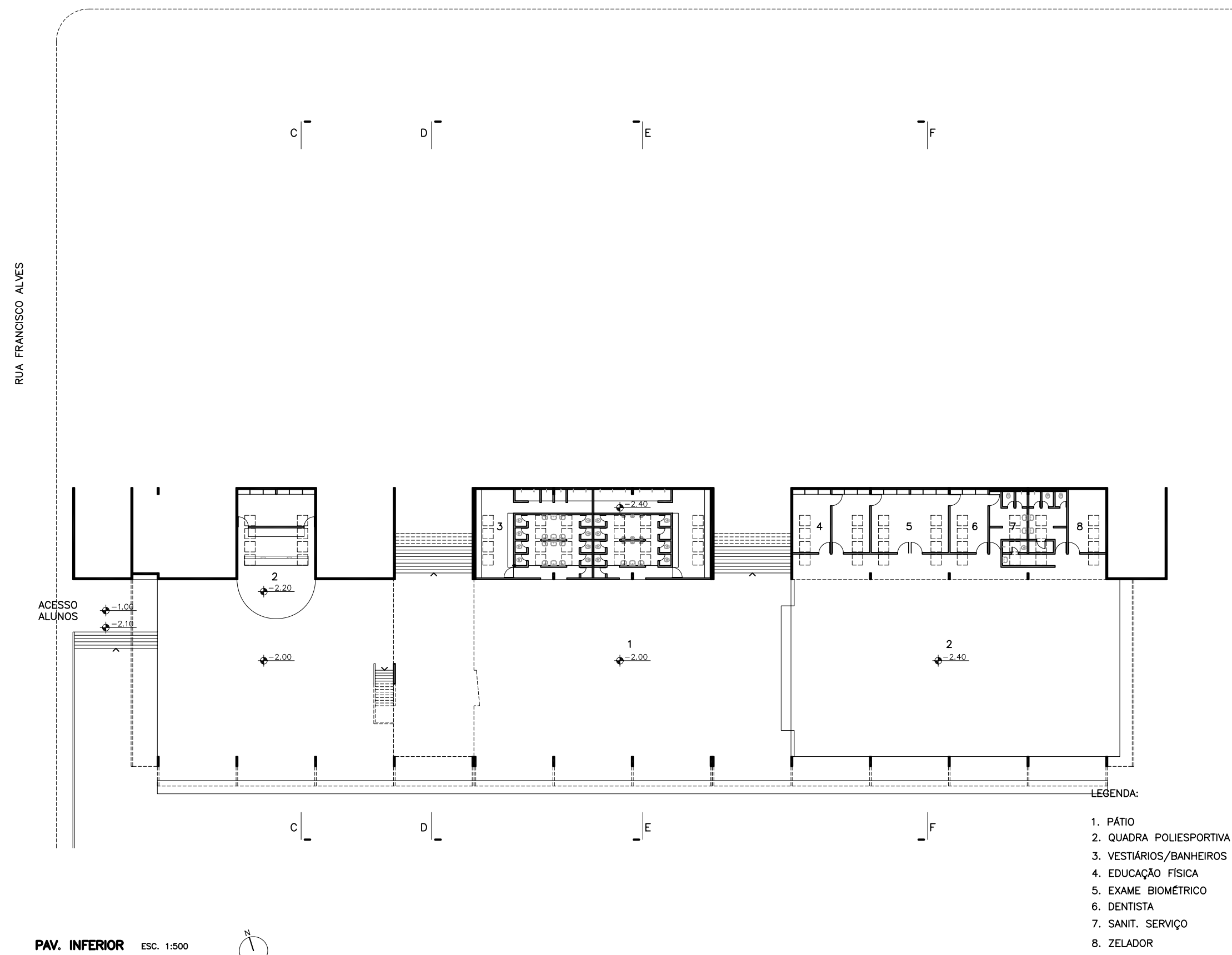


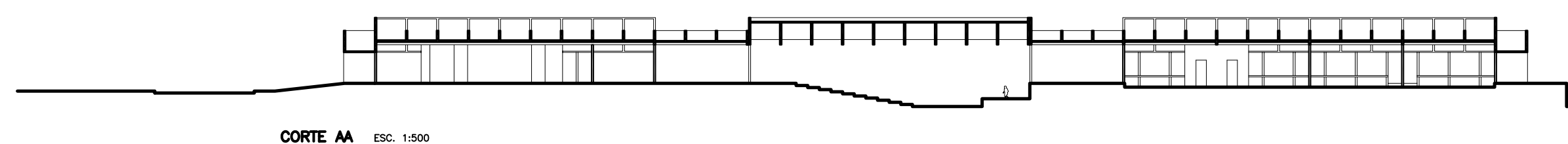

CORTE AA ESC. 1:500

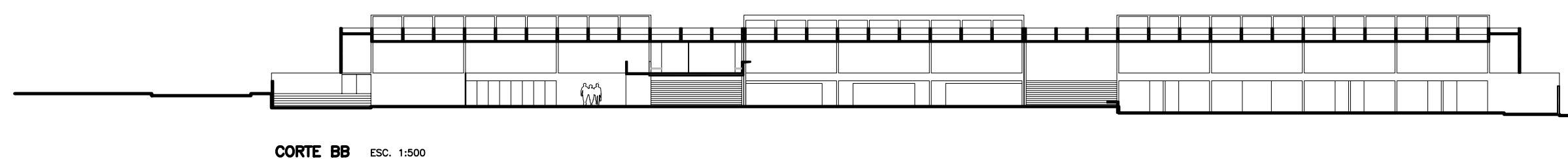

CORTE BB ESC. 1:500 


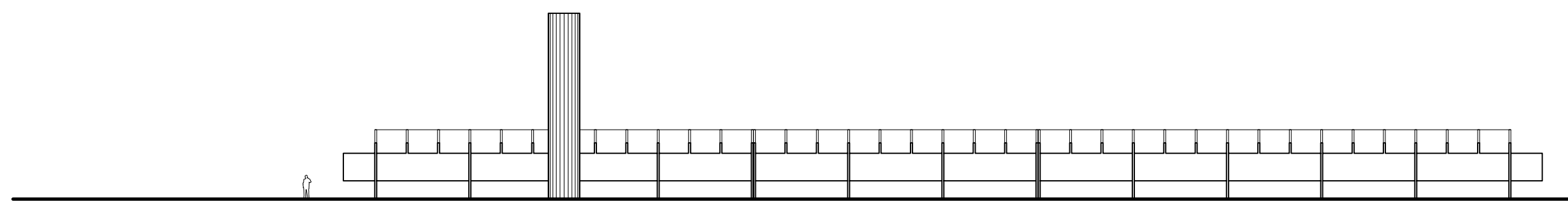

ELEVAGAO NORTE ESC. 1:500

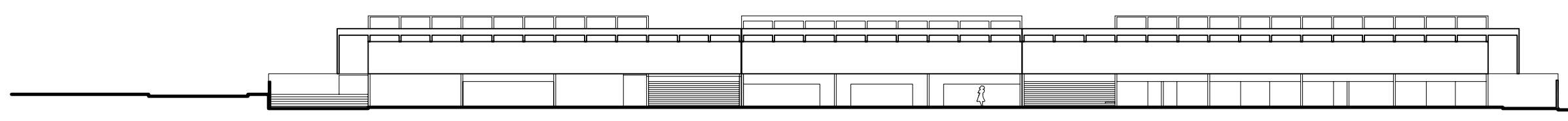

ELEVAÇAO SUL ESC. 1:500 


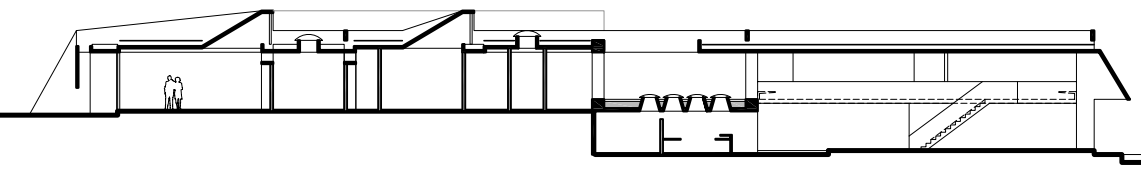

CORTE CC ESC. 1:500

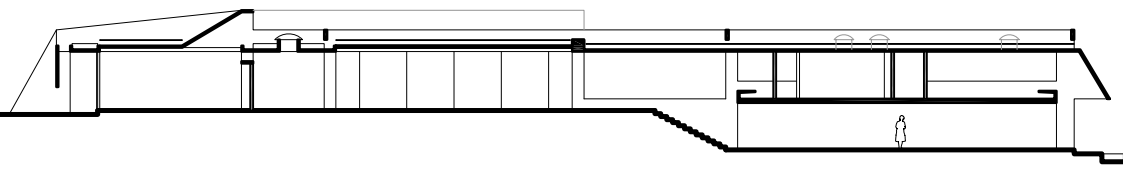

CORTE DD ESC. 1:500 


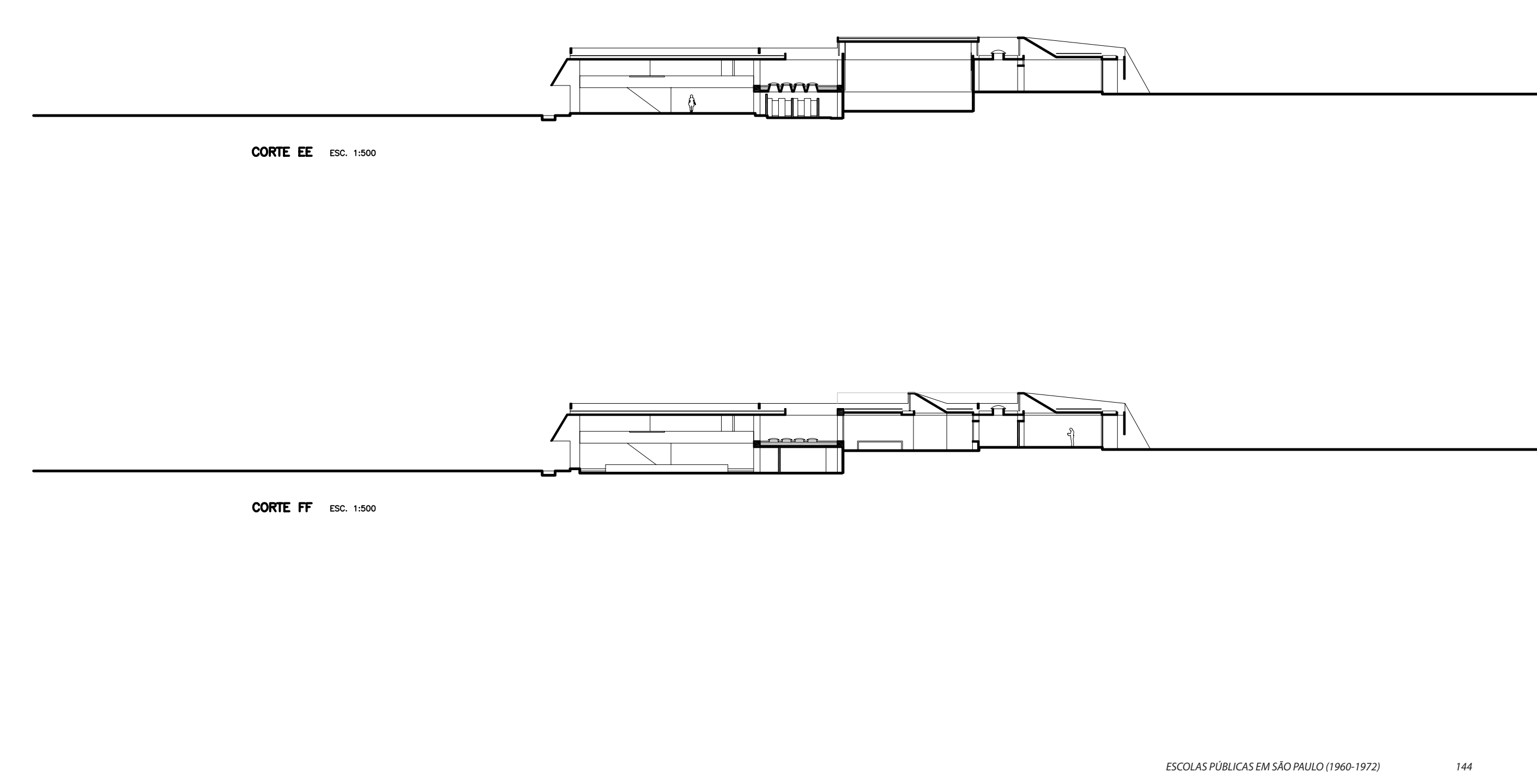




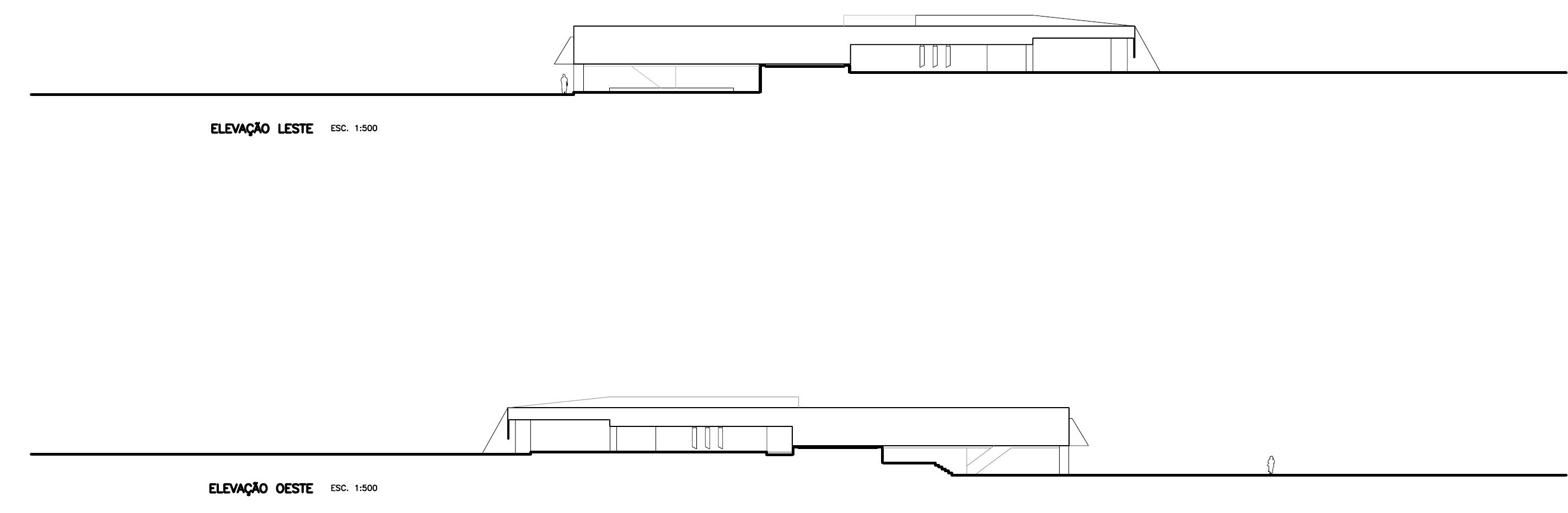




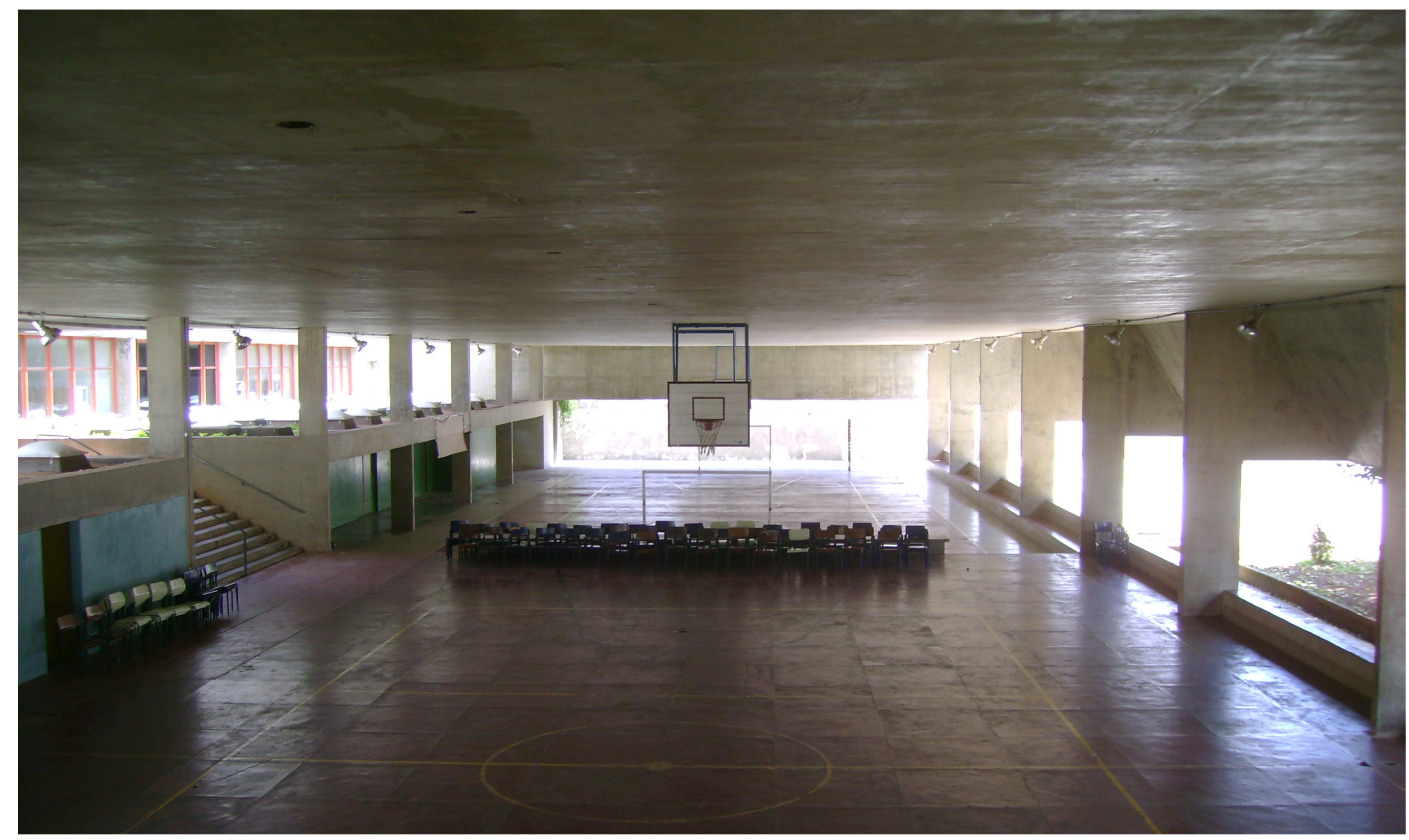




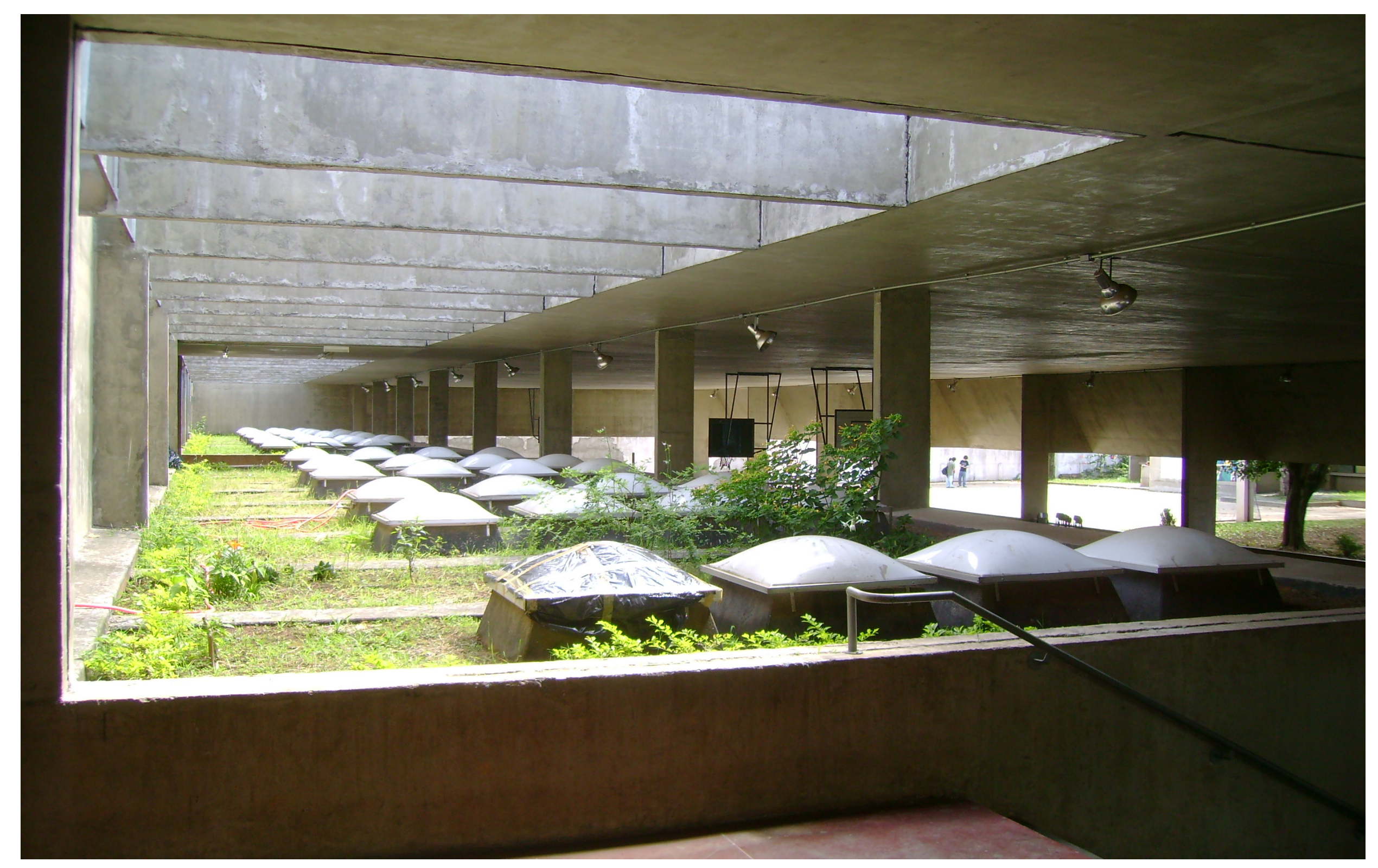



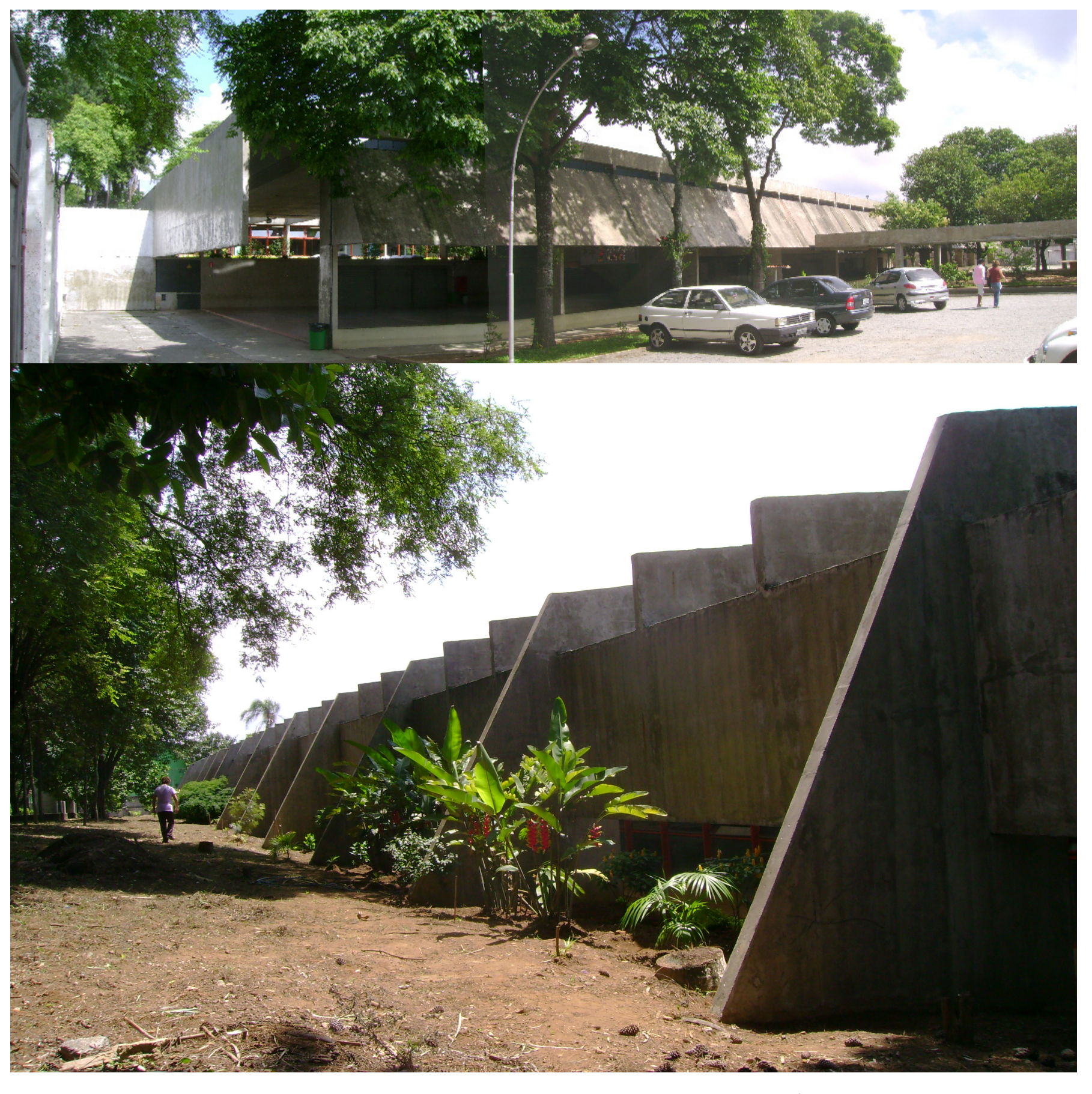

ESCOLAS PÚBLICAS EM SÃO PAULO (1960-1972) 

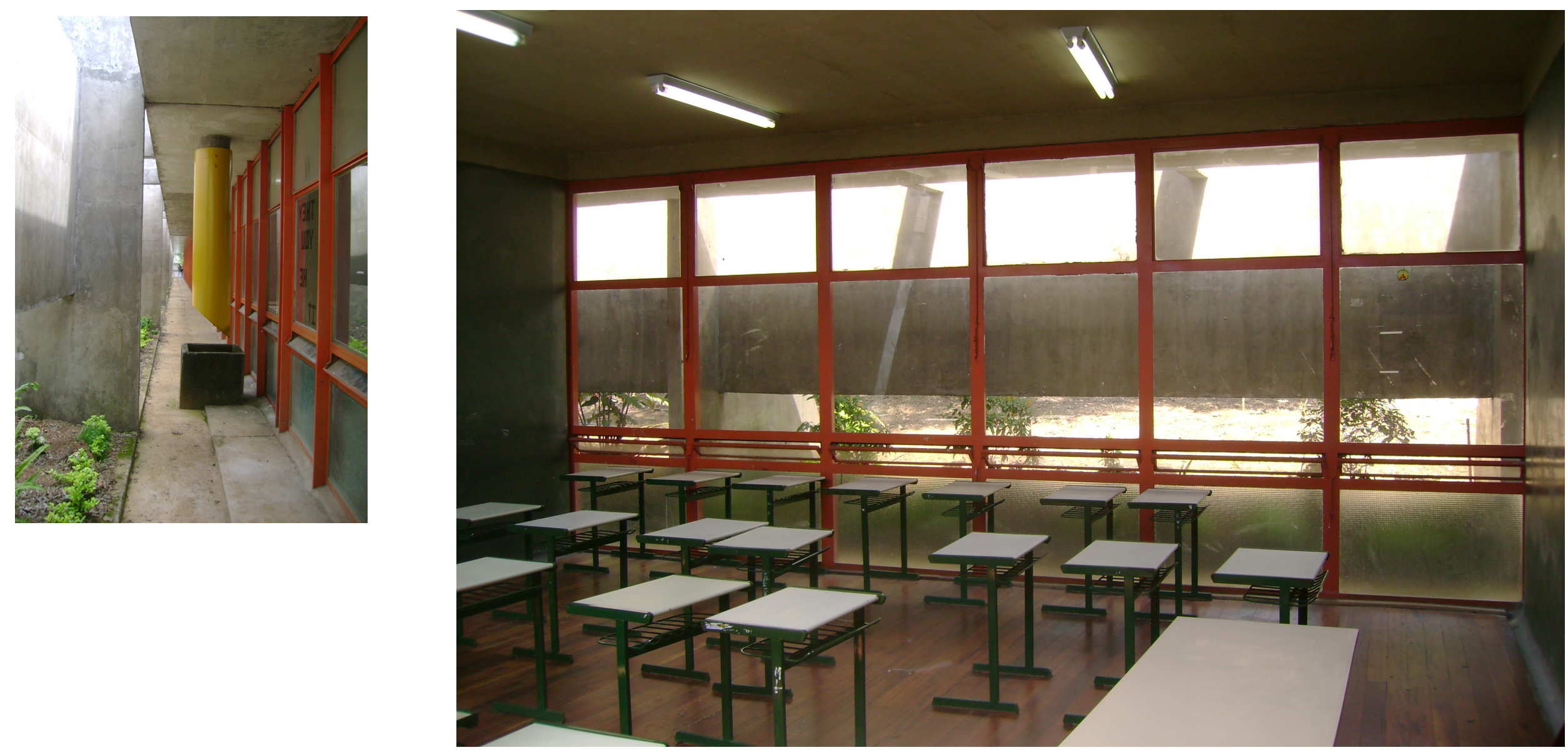


\section{EE Dom José de Camargo Barros / 1969*}

Av. Presidente Kennedy, 886, Cidade Nova I, Indaiatuba, SP

Arquiteto: Ubyrajara Gilioli.

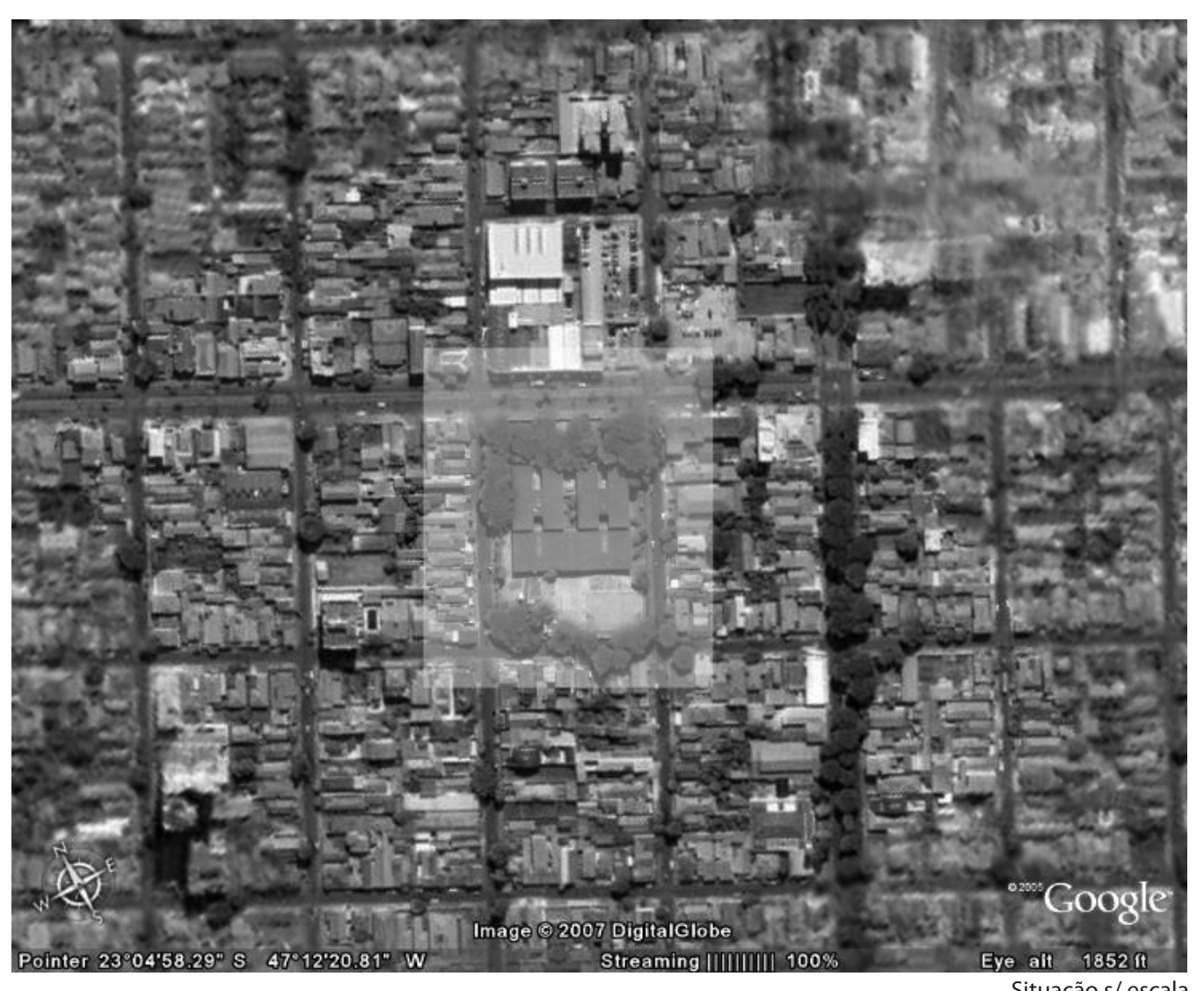

Situação s/ escala 
Das escolas reunidas nesse catálogo essa é a única que foi construída com outro projeto.

De qualquer maneira, parece-nos importante apresentar o projeto original, dado o grau de integração entre escola e cidade que sua implantação sugeria. Para o arquiteto (informação verbal) ${ }^{1}$, nesse projeto não construído, a experiência da escola aberta para a comunidade foi levada às últimas consequências. $O$ terreno escolhido para sua implantação ocuparia uma quadra toda da cidade. O arquiteto então sugeriu uma grande cobertura que, em suas palavras, abrigaria "um conjunto de acontecimentos sob um mesmo teto".2

As salas de aula foram localizadas nas extremidades laterais da quadra, estando o centro reservado às atividades de caráter mais coletivo, como pátio coberto de recreação, cantina, grêmio e outros. Dessa forma podia-se imaginar que a cidade poderia fluir através do interior da escola mesmo com as áreas mais especíicas fechadas.

Outro aspecto que merece atenção no projeto dessa escola era o programa, que previa (como na escola da Vila Paulicéia, em São Bernardo do Campo, e a escola da Liberdade, do arquiteto Paulo Mendes da Rocha), além das salas de aula para o pré-primário, $1^{\circ}$ e $2^{\circ}$ graus, oficinas para prática industrial, laboratórios de ciências, salas de artes plásticas, economia doméstica, prática agrícola entre outras atividades. Ambientes que favoreceriam a aproximação entre as atividades escolares e a vida cotidiana, conforme preconizava o educador Anísio Teixeira e difundia a equipe de planejamento do FECE. Programa que, segundo Gilioli, “irá pouco a pouco se empobrecendo até o ponto de praticamente reduzir-se a apenas salas de aula".3

Entrevista realizada com o arquiteto Ubyrajara Gilioli em seu escritório no dia 22/03/2007.

GILIOLI, Ubyrajara. Arquitetura e Lugar. 1995. Tese de Doutorado- Faculdade de Arquitetura e Urbanismo da Universidade de São Paulo (FAUUSP), São Paulo, p. 102

3 GILIOLI, Ubyrajara. Arquitetura e Lugar. 1995. Tese de Doutorado- Faculdade de Arquitetura e Urbanismo da Universidade de São Paulo (FAUUSP), São Paulo, p. 102. 

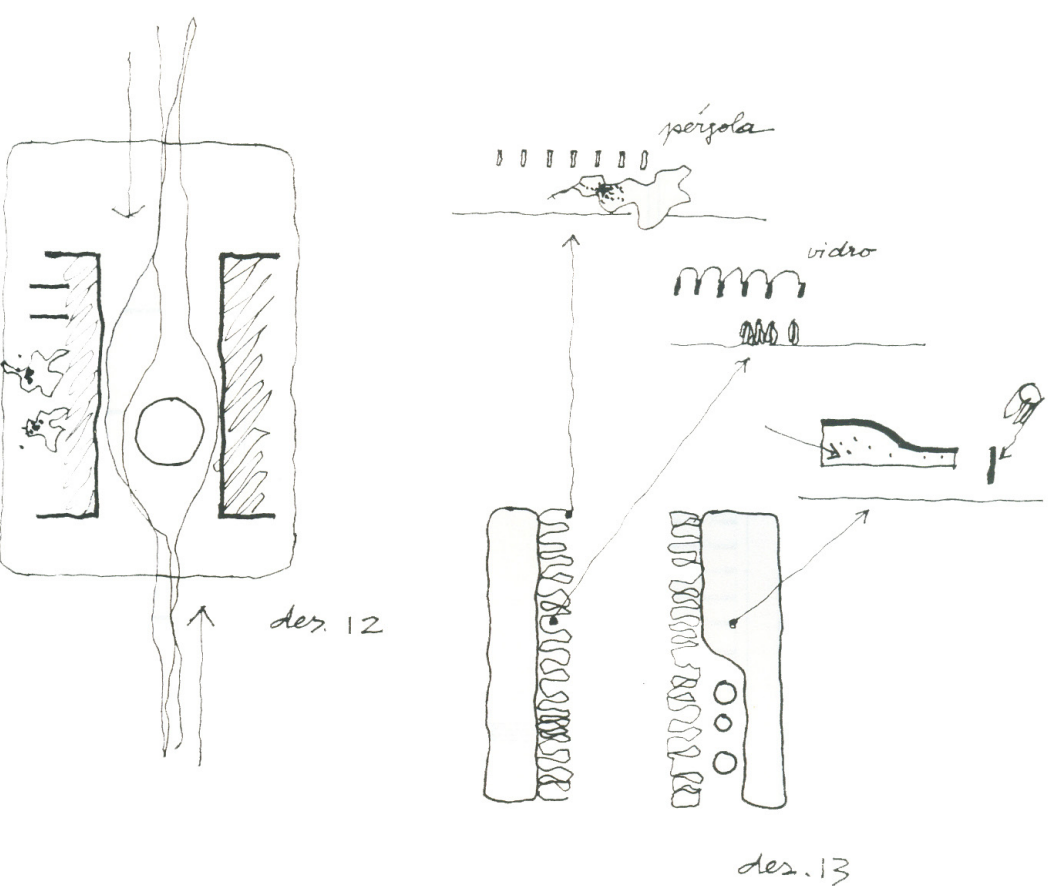 \\ Croquis do arquiteto Ubyrajara Gilioli}

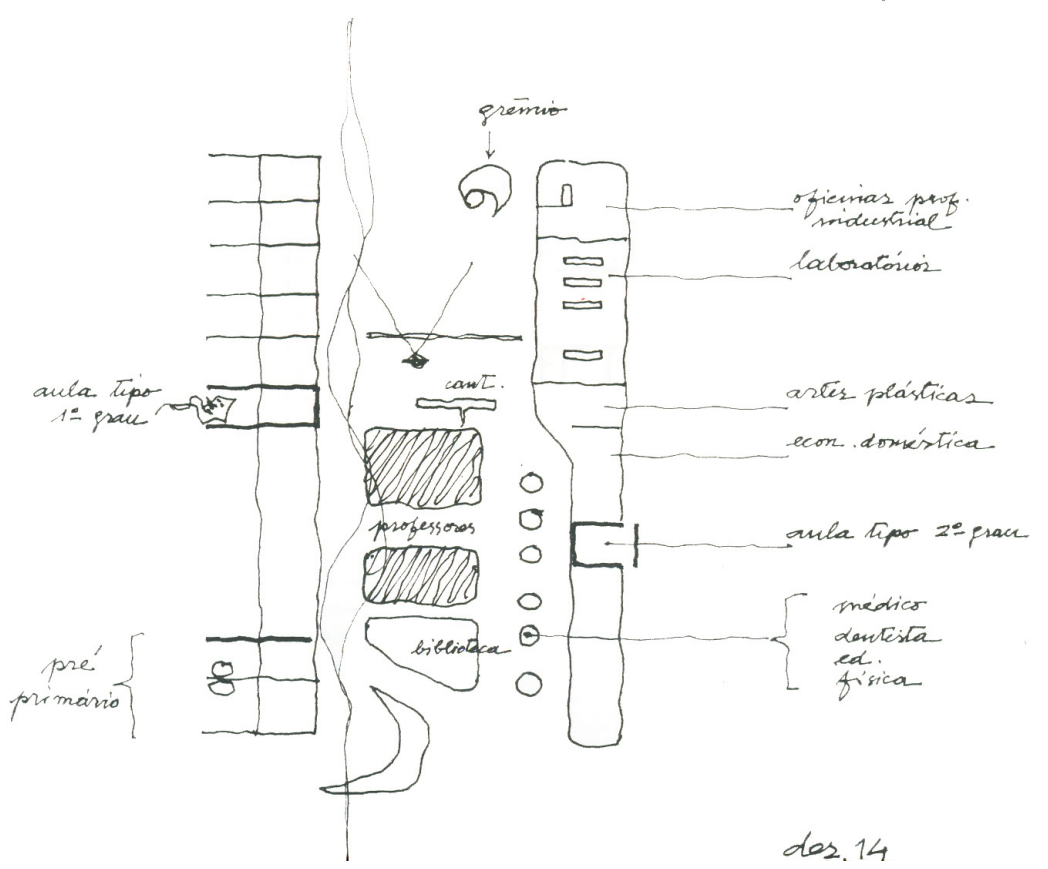




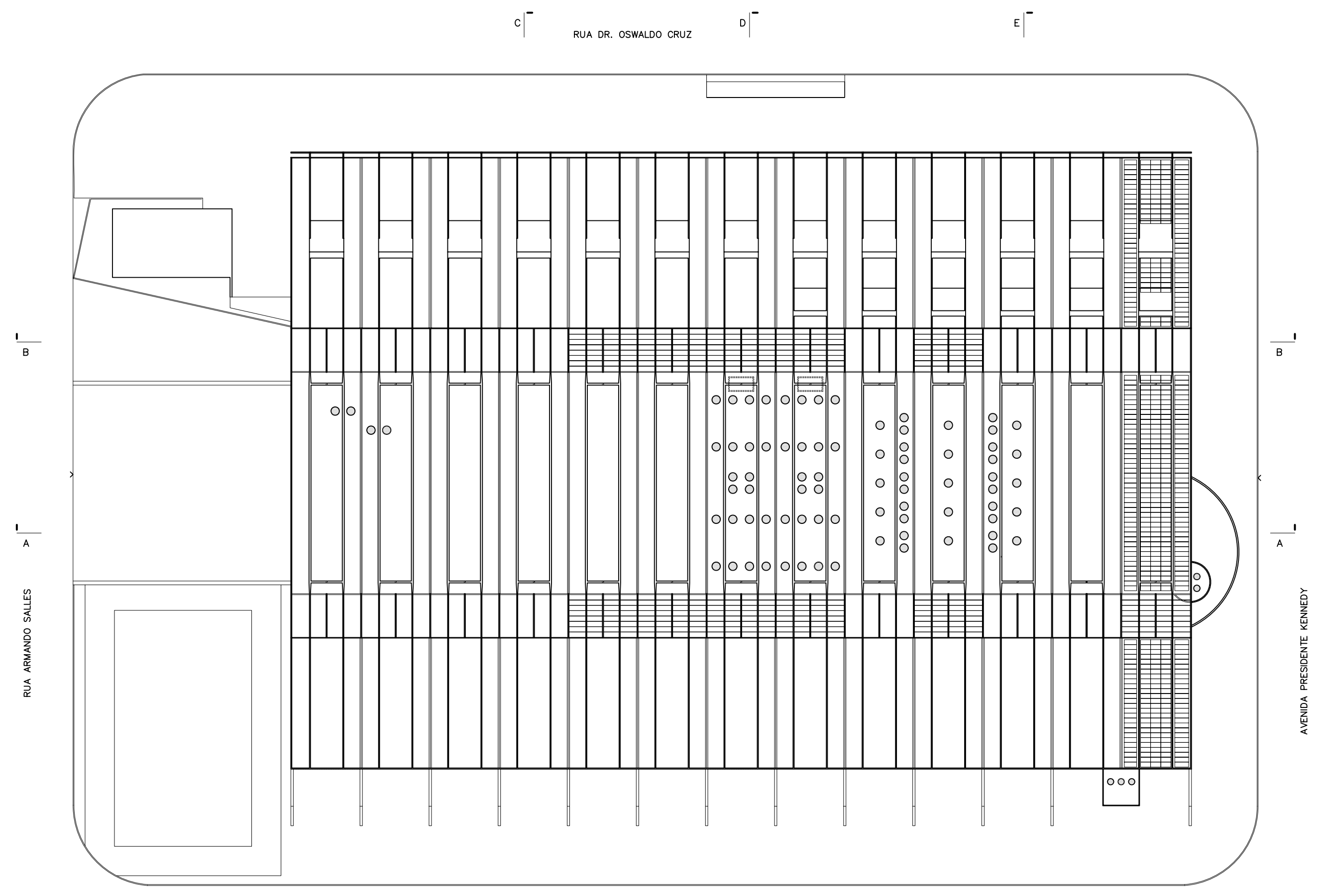

PLANTA DE COBERTURA ESC. 1:500

c|_ rua dos andradas D _

ESECLLAS PÚBLLCAS EM SÄ PAULLO (1960-1972) 


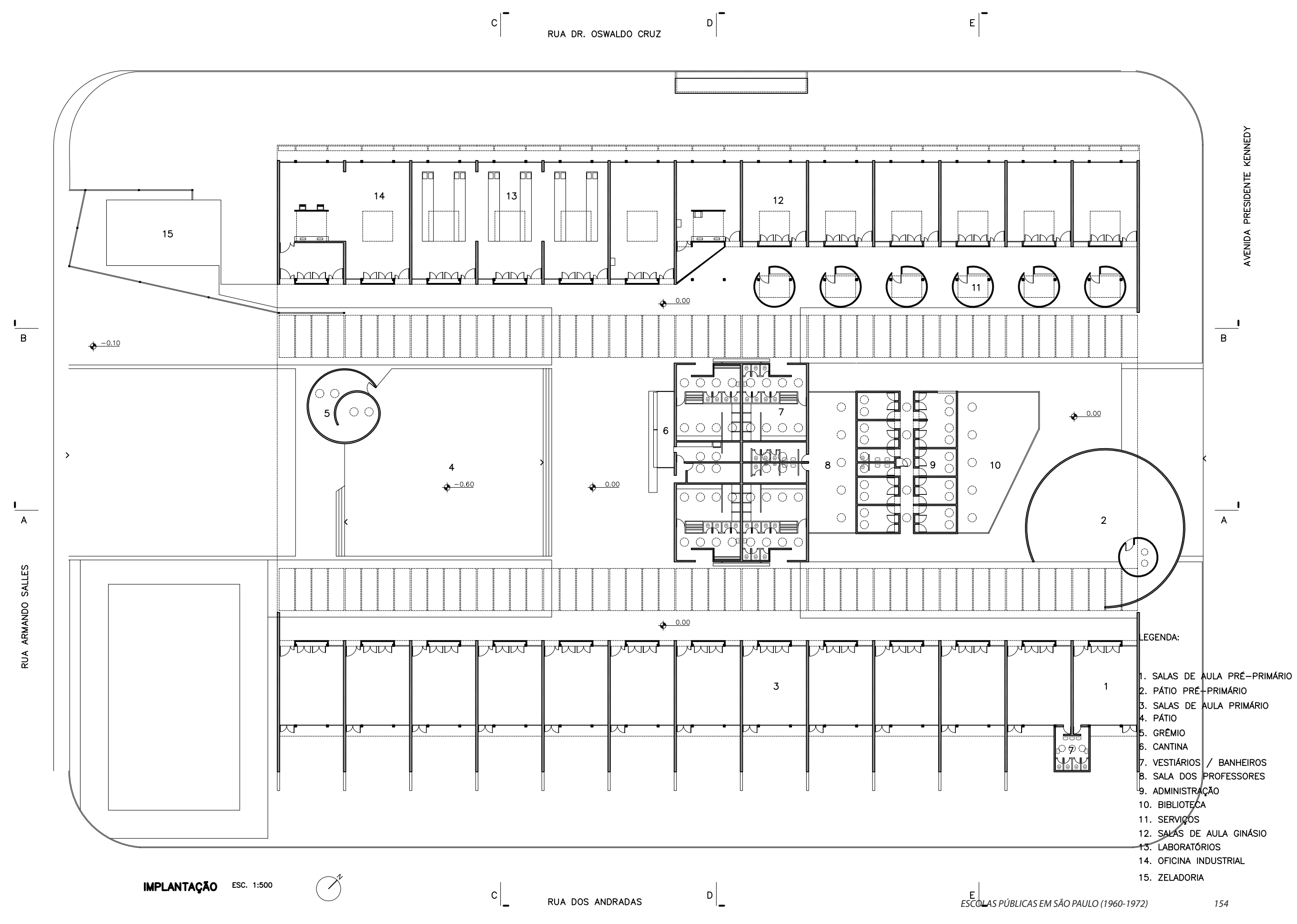




\section{L}

CORTE AA ESC. 1:500

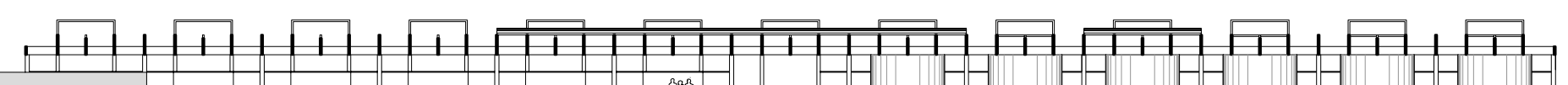

CORTE BB ESC. 1:500 


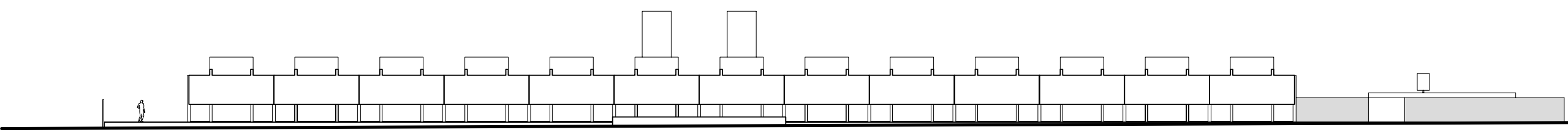

ELEVACAO NORTE ESC. 1:500

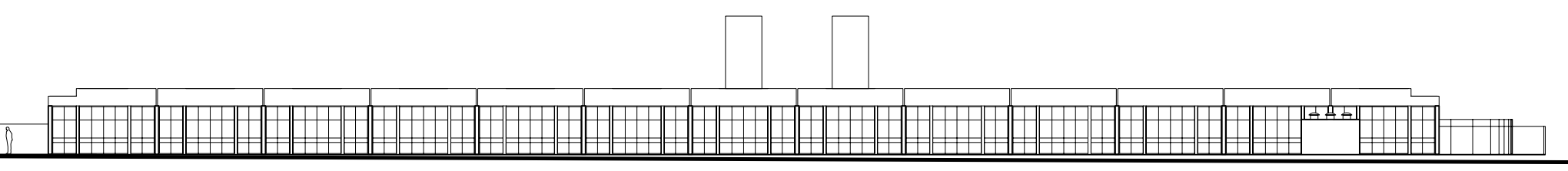

ELEVACAOO SUL ESC. 1:500 


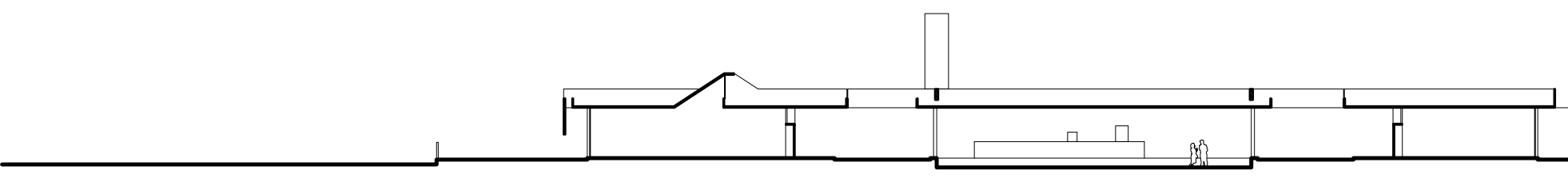

CORTE CC ESC. 1:500

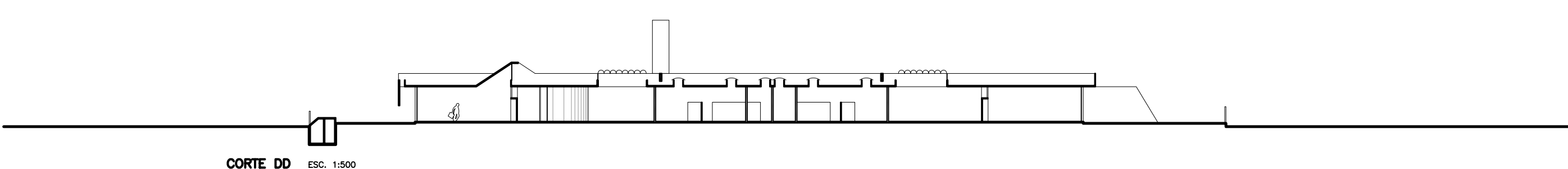

CORTE DD ESC. 1:500

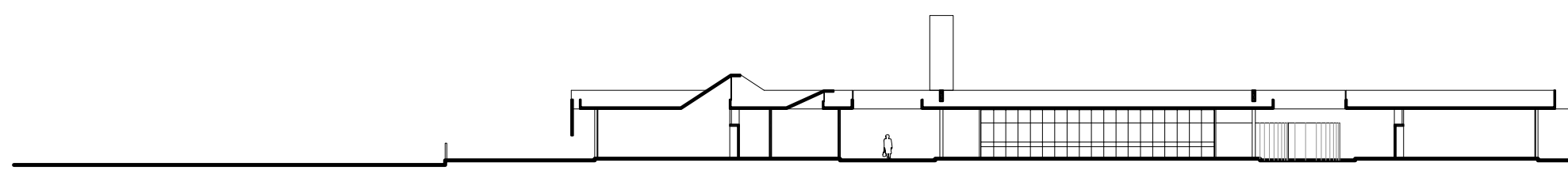

CORTE EE ESC. 1:500 


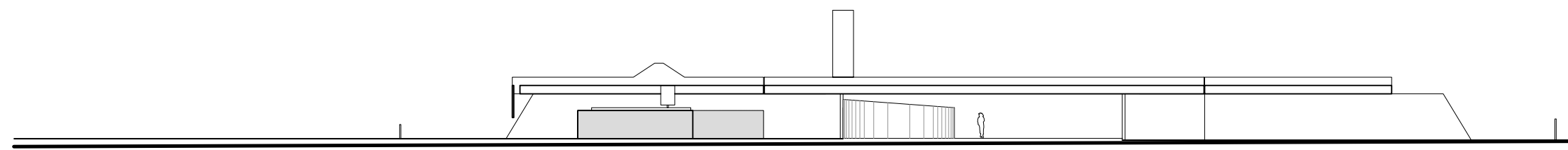

ELEVAÇAO OESTE ESC. 1:500

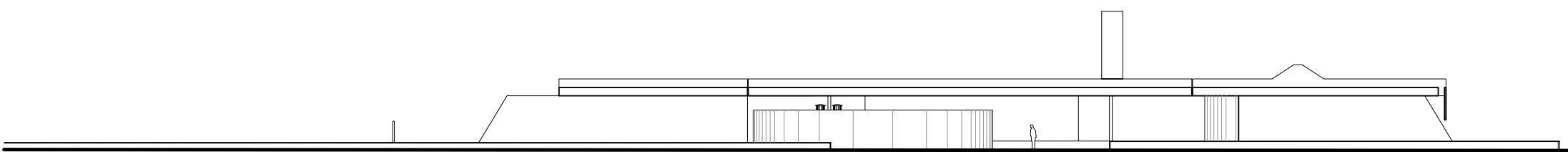




\section{EMEB Mário Martins de Almeida / 1966}

Rua São João, 133, Jardim São Paulo, São Bernardo do Campo, SP

Arquiteto: Paulo Bastos e Leo Bonfim Jr.

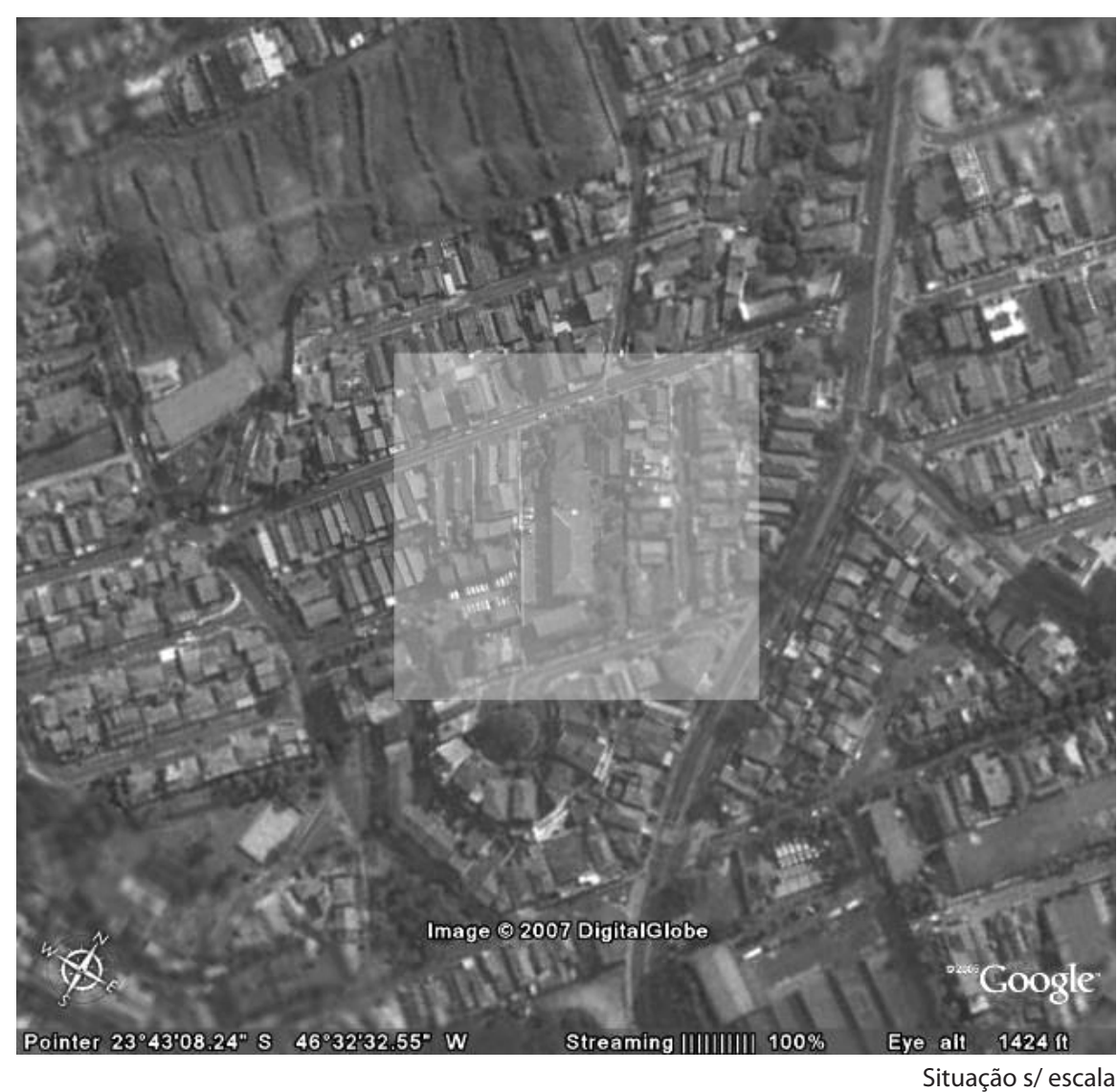



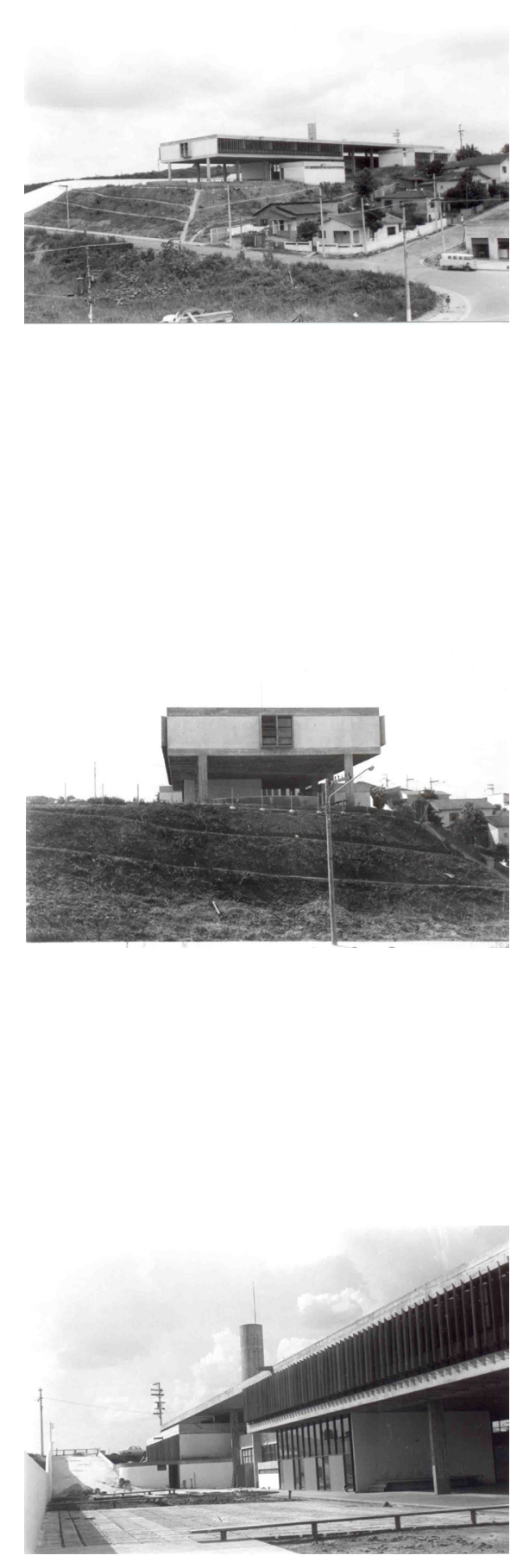

A escola de Vila Brasília tem, para Paulo Bastos (informação verbal)', grande importância porque inaugurou, em sua trajetória profissional, uma maneira de conceber o espaço que depois foi desenvolvida em outros projetos e obras: uma grande cobertura que agrega cada função com sua cobertura e estrutura independentes.

Localiza-se num terreno de acentuado declive, escolhido pelos próprios arquitetos ${ }^{2}$. Contrariando a forma convencional de ocupar um sítio com essas características, os arquitetos implantaram-na no sentido perpendicular às curvas de nível. Decisão que gerou certa dominância da escola na paisagem do bairro, sem que a construção, ao nível da rua de acesso, destoasse muito das construções circunvizinhas pois a escola, no nível da rua São João, tem a altura de um sobrado.

Da rua, o acesso é feito por uma escadaria. Chega-se a um pátio coberto, recreação do pré-primário, cujas salas encontram-se ao lado esquerdo de quem entra, em volume independente. Do lado direito, paralelo ao volume das salas de aula do pré fica o bloco administrativo. Desse lugar um jogo de rampas conduz o transeunte ao nível mais alto, onde estão situadas as salas de aula do primário, ou então ao pátio coberto de recreação, num nível abaixo. Dois outros volumes situam-se nesse nível e a ele estão diretamente vinculados, refeitório/cozinha e banheiros. A comunicabilidade dos espaços por meio da utilização de rampas articuladas com níveis a meio-piso é influência direta de Artigas e confere fluidez espacial ao edifício.

As salas de aula abrem-se para o exterior nas faces Nordeste e Sudoeste e são guarnecidas por brises verticais (placas de argamassa armada) que as protegem da incidência direta da luz solar. As coberturas dos volumes independentes (salas de pré-primário, administração, cozinha/banheiros) foram pensadas como tetos-jardim. 0 volume das salas de pré-primário tem, além dos caixilhos do piso ao teto (que funcionam também como portas de conexão das salas com o pátio externo de recreação e o parquinho), domus de iluminação e ventilação, que muito contribuem para a qualidade das mesmas. As salas de aula do primário são como as dos "pequenos", iluminadas zenitalmente e acessadas por uma galeria de circulação central, cuja luz provém de uma janela, de onde pode-se

1 Entrevista realizada com o arquiteto Paulo Bastos em 30/03/2007.

Prática comum naquele momento, especialmente nos projetos desenvolvidos em São Bernardo do Campo. Segundo o arquiteto Paulo Bastos (na mesma entrevista citada na nota acima): "A prefeitura de São Bernardo do Campo, onde recentemente havia se instalado a indústria automobilística, demandava muito trabalho. Lá havia um setor de Planejamento que com um ano de antecedência, pesquisava e listava as obras necessárias (escolas, creches, postos de saúde, estádios de futebol - tudo o que fosse necessário à vida urbana) e então contratava os projetos. O programa era dado, os arquitetos escolhiam o terreno e com rapidez uma mensagem era mandada para a Câmara, com a solicitação de desapropriação do terreno (normalmente eram terenos particulares, comprados pela prefitura). O arquiteto que estava à frente desse processo, chefe do setor de Planejamento da Prefeitura era Jorge Bonfim, arquiteto que fez o projeto para o Paço Municipal da cidade." 
avistar a paisagem.
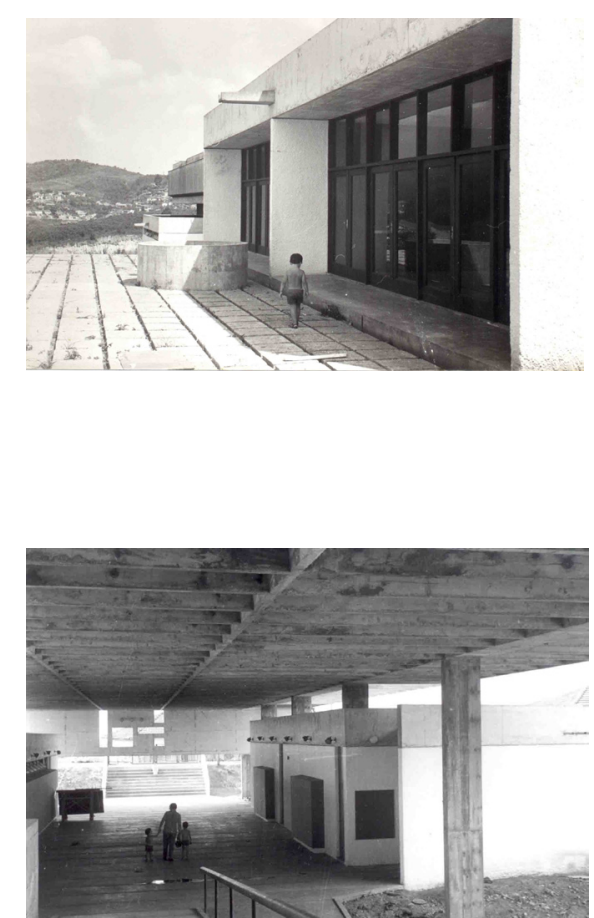

Segundo o arquiteto Paulo Bastos, "tanto das salas de aula quanto particularmente do pátio, podia-se ver toda a paisagem do entorno. Era uma forma de ligar, vamos dizer assim, o usuário, o morador, a comunidade à escola. Ligar de todas as formas: visualmente, no uso e na ausência de barreiras entre eles e a escola"(informação verbal) ${ }^{3}$.

A cobertura principal era plana e impermeabilizada. Contava no primeiro trecho com uma sucessão de pérgolas, além do reservatório de água e o duto de exaustão do fogão da cozinha e no segundo, uma série de domus de iluminação e ventilação das salas de aula. As águas das chuvas eram sempre conduzidas através de gárgulas aos receptáculos, conferindo dramaticidade ao espaço nos momentos de chuva.

A escola, originalmente estadual, foi transformada numa EMEB (Escola Municipal de Ensino Médio) e encontra-se num estado razoável de manutenção. Algumas alterações chamam a atenção: a principal delas foi a construção de um anexo na porção sudeste do terreno, obstruindo a visão da paisagem, principalmente do nível do pátio de recreação mais baixo. Parte desse mesmo pátio foi ocupado. Sobre o segundo trecho da laje existente (cobertura principal) foi construído um telhado de quatro águas convencional, obstruindo as aberturas zenitais. As coberturas dos volumes independentes se tranformaram (grande parte deles) em depósitos de carteiras velhas. 


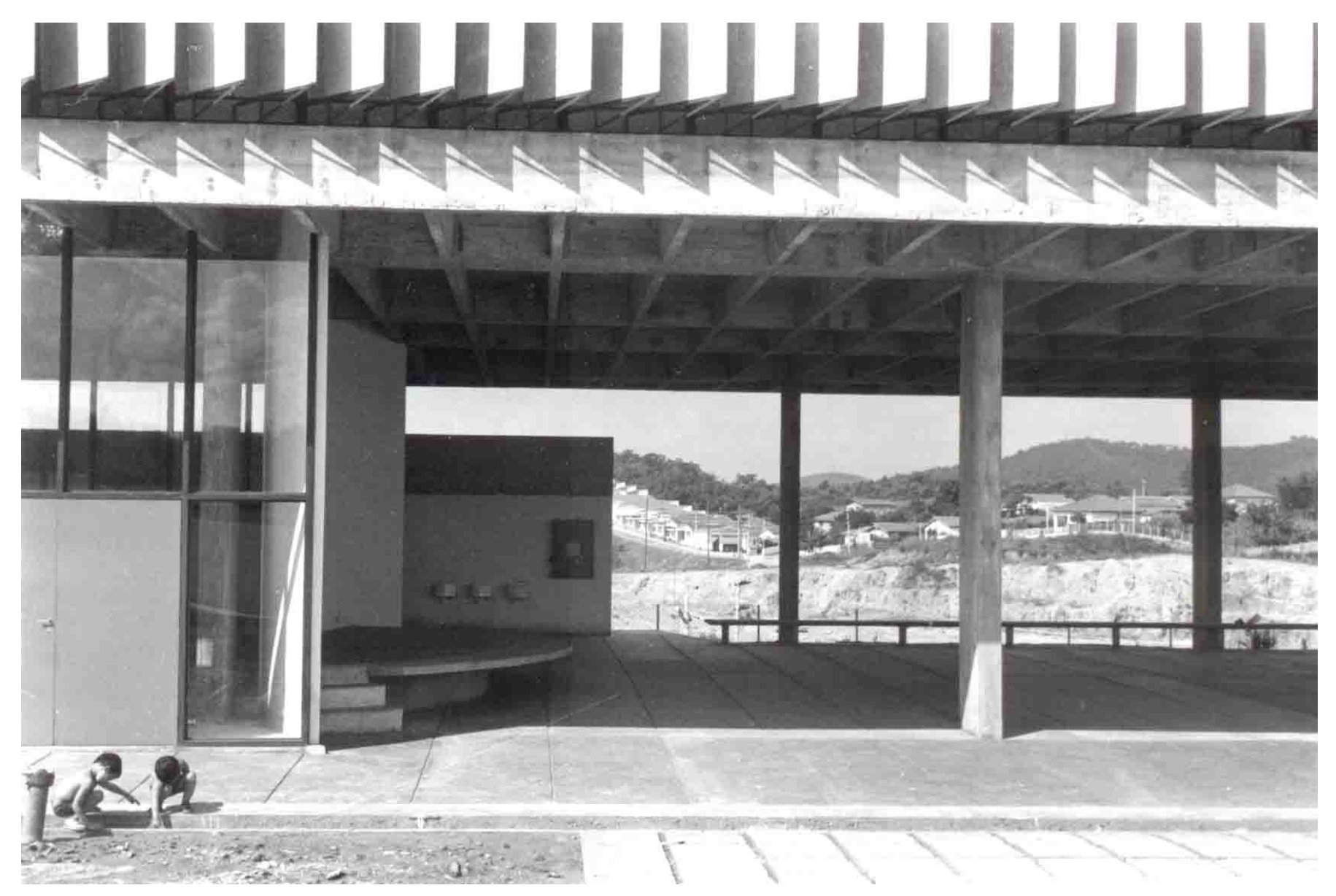




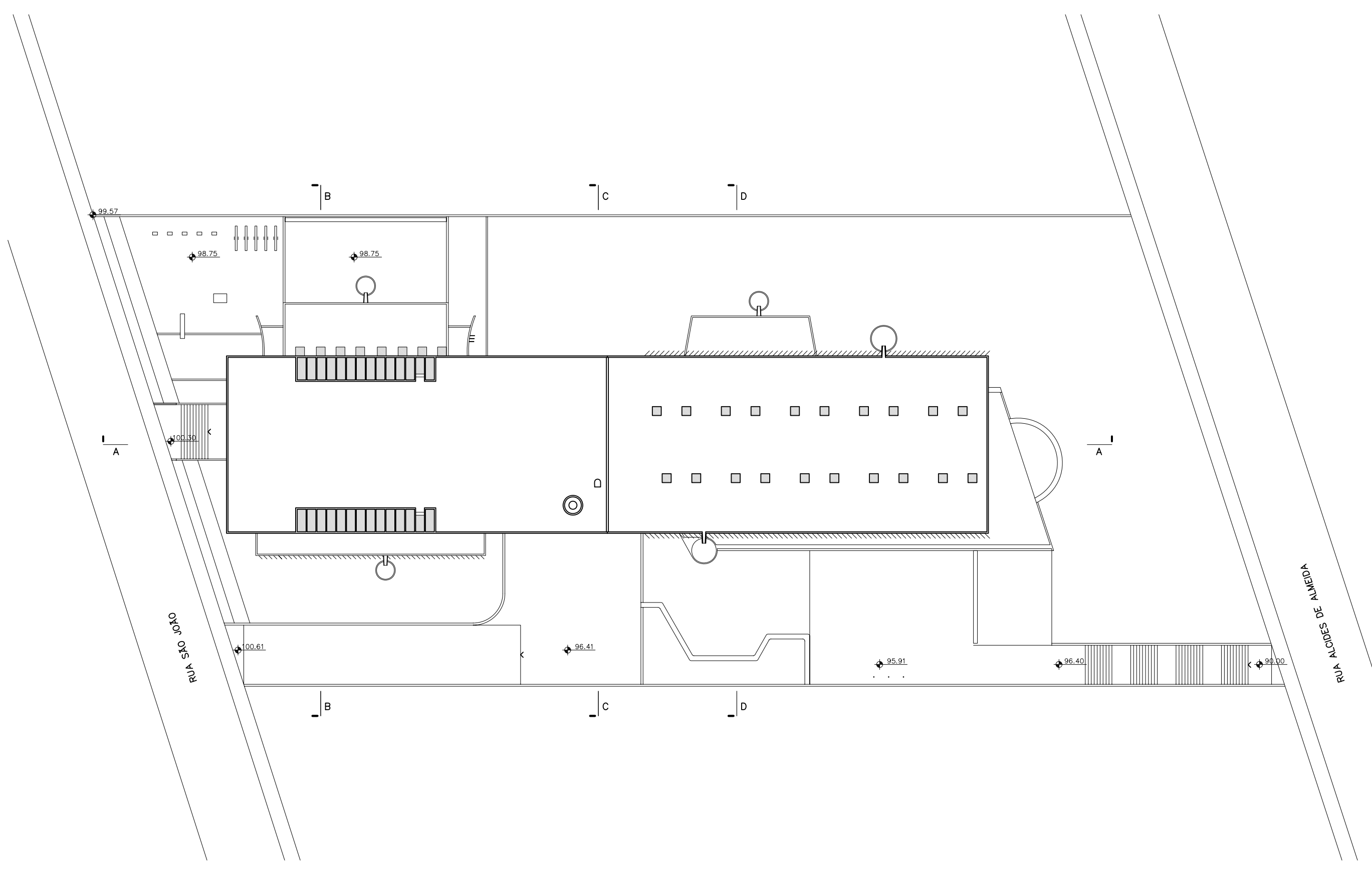




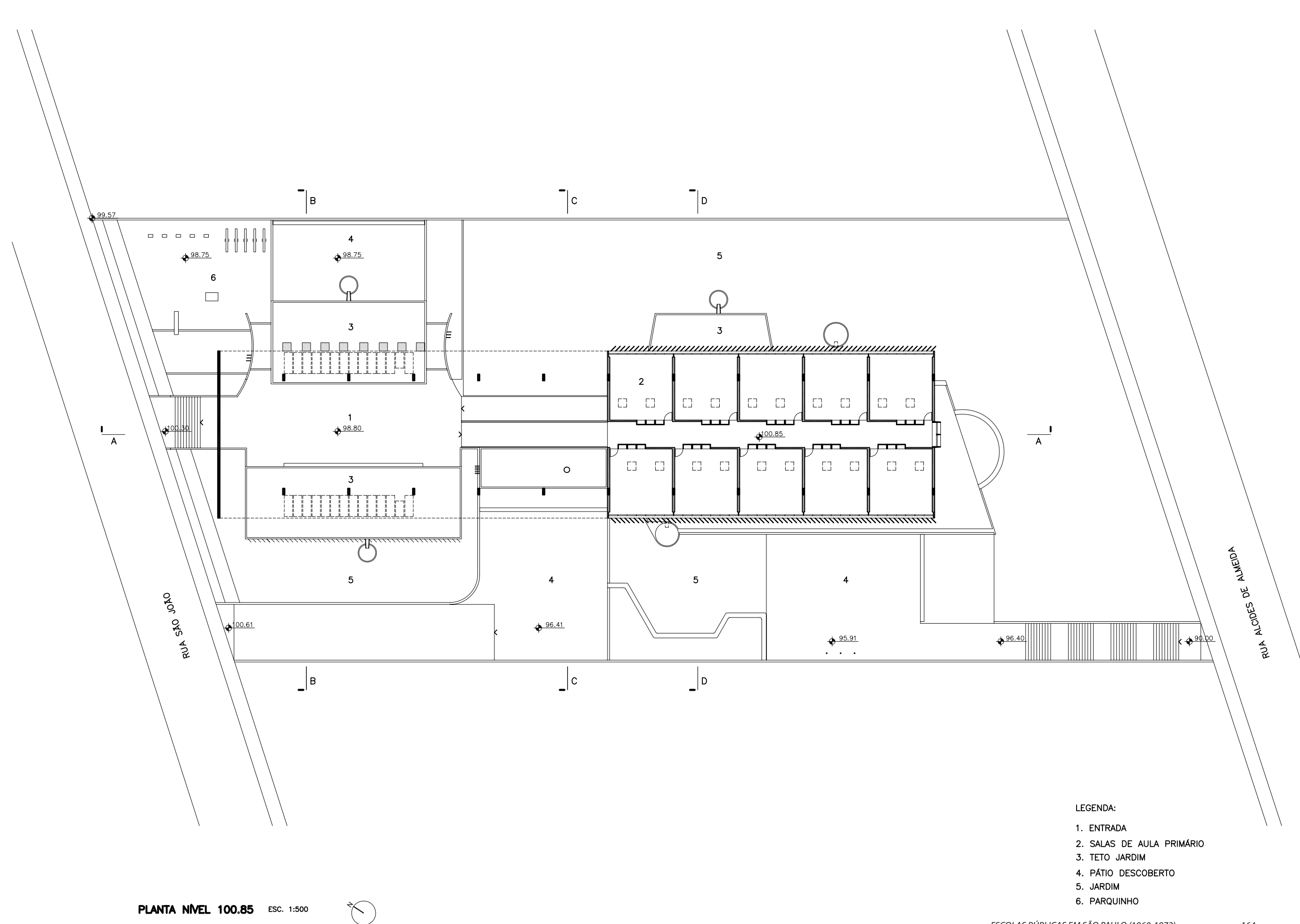

ESCOLAS PÚBLICAS EM SÃO PAULO (1960-1972) 


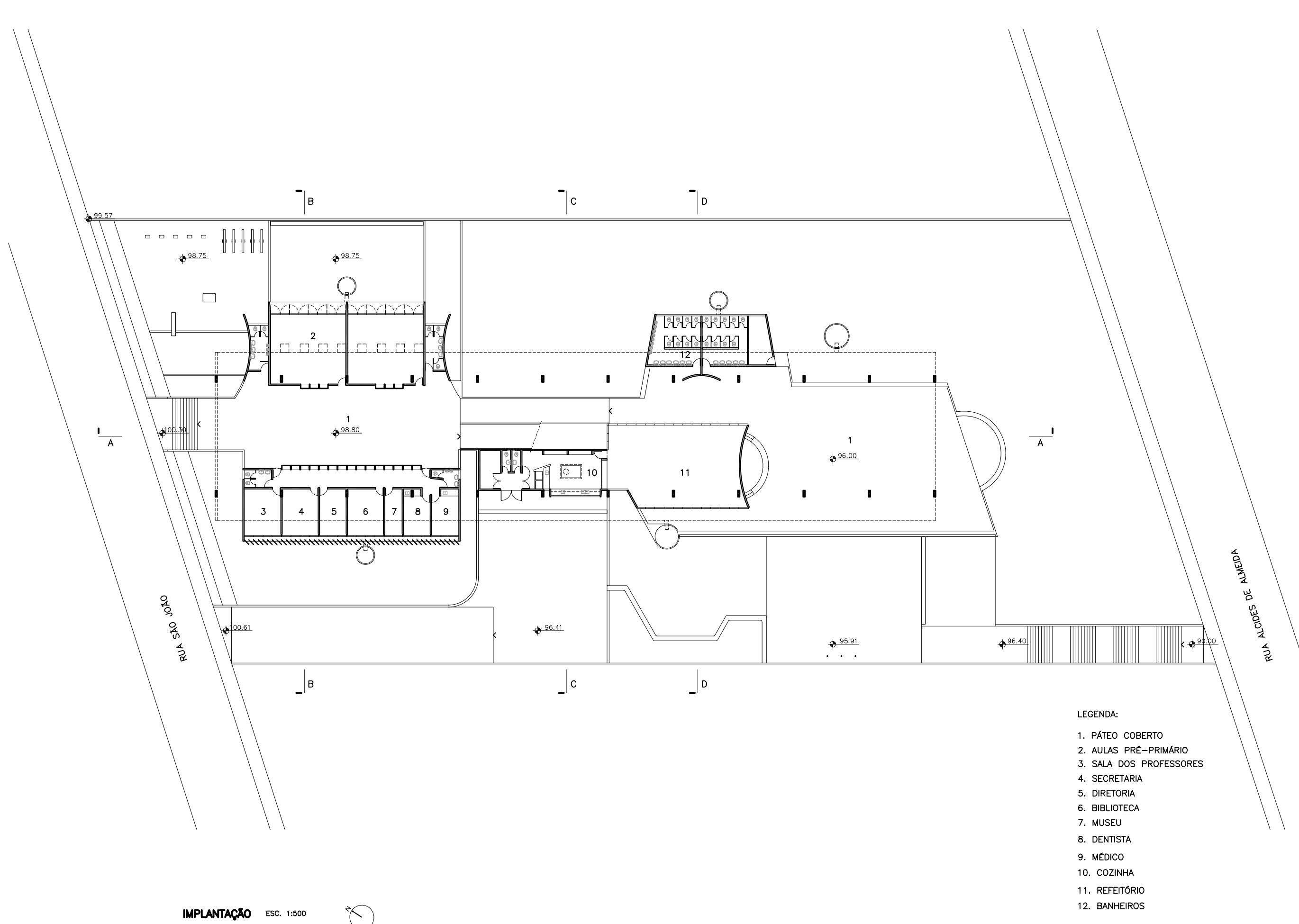




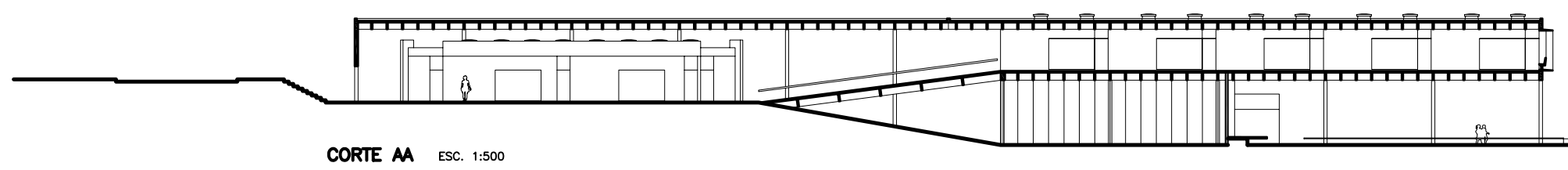

CORTE AA ESC. 1:500
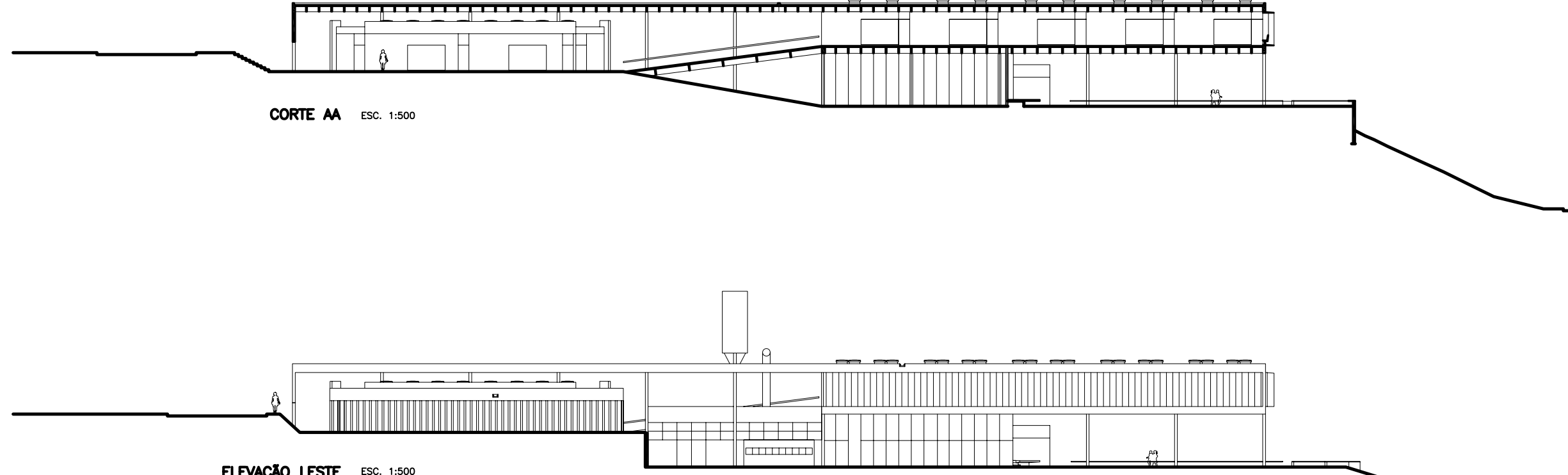

ELEVAĢAO LESTE ESC. 1:500

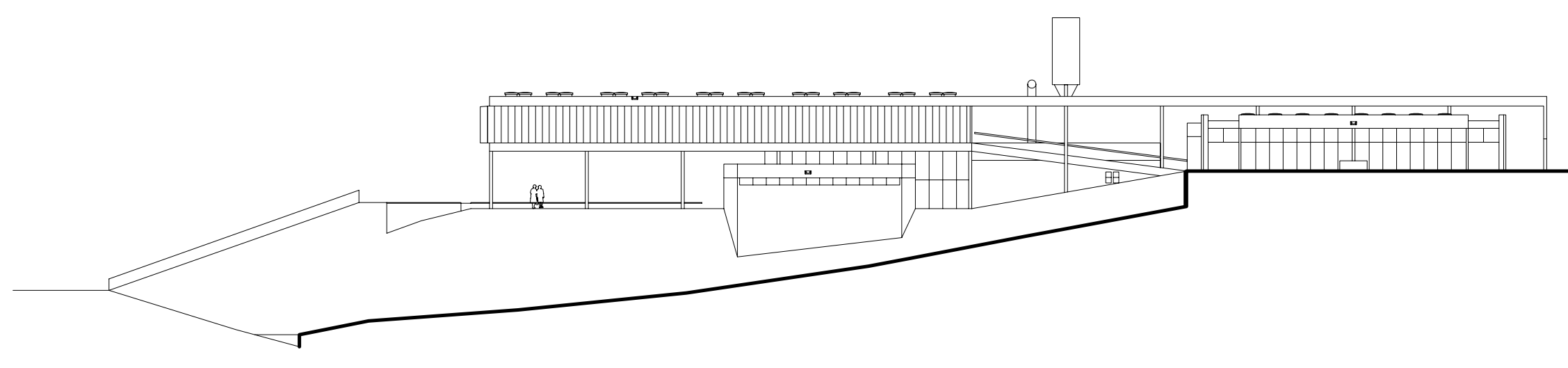

ELEVACAO OESTE ESC. 1:500 


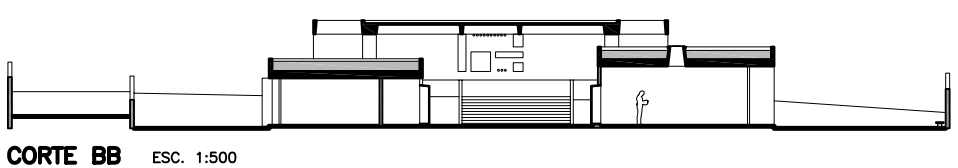

CORTE BB ESC. 1:500

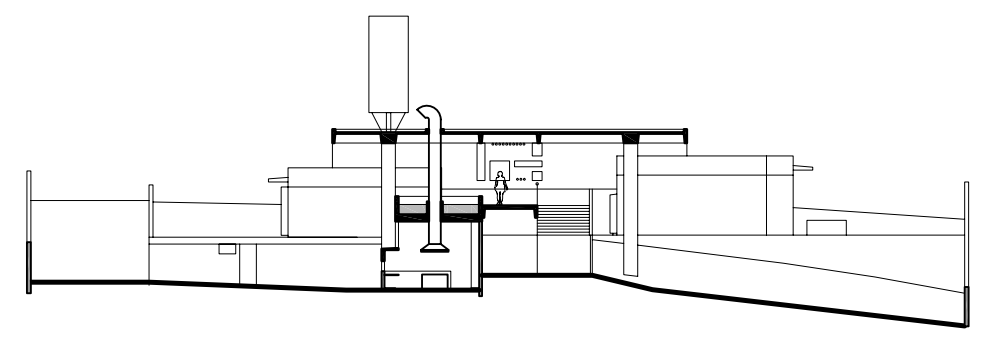

CORTE CC ESC. 1:500

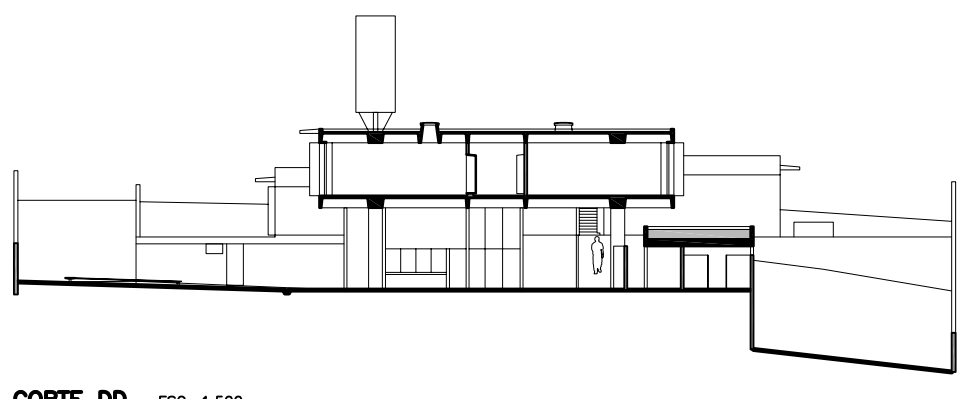

CORTE DD ESC. 1:500

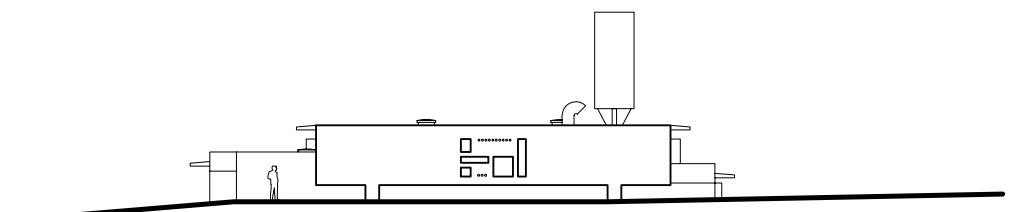

ELEVAÇAO NORTE ESC. 1:500

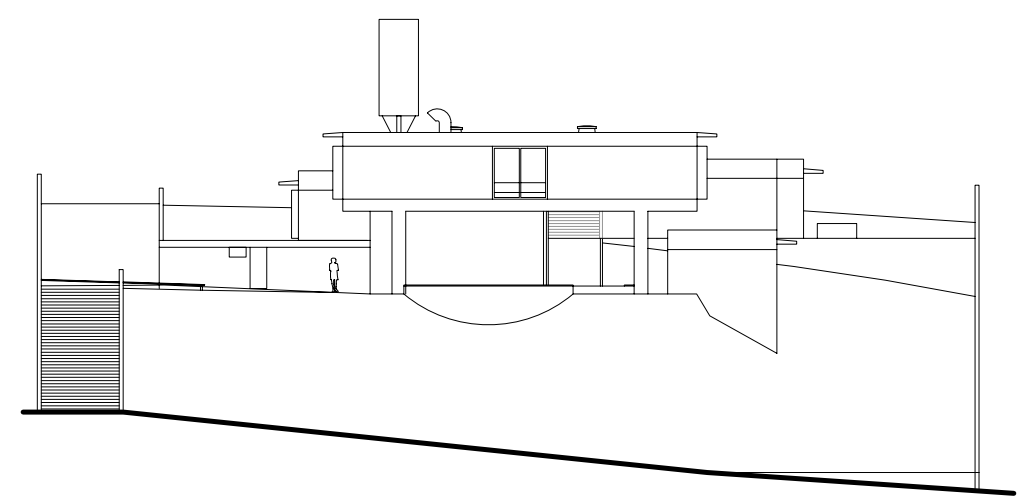

ELEVAGAO SUL ESC. 1:500 

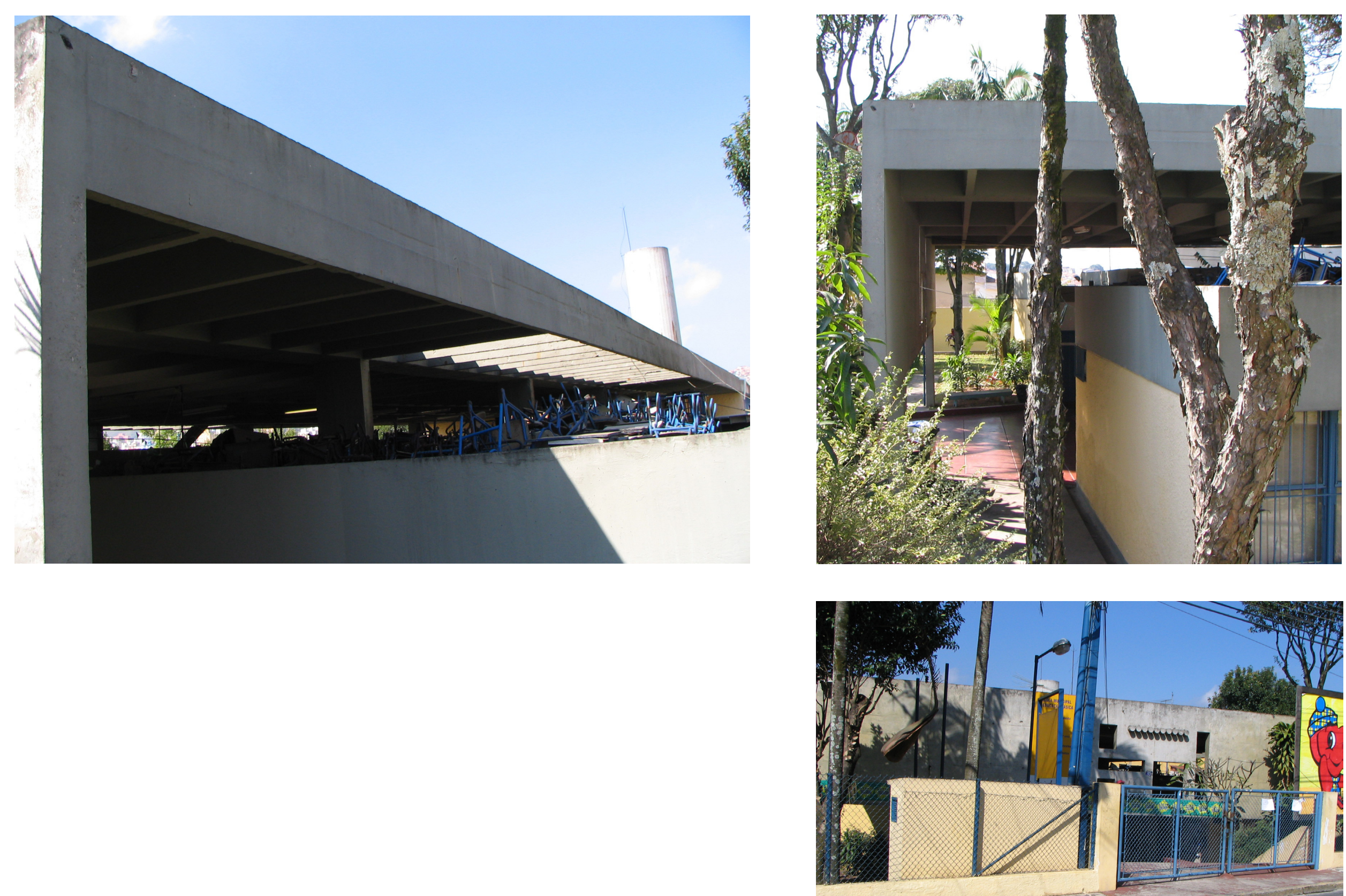

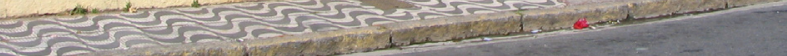
1 . 
EE Euclides Deslandes (antigo GE do Jardim Ipê) / 1967

Estrada dos Casa, 2651. Jardim Ipê, São Bernardo do Campo, SP

Arquitetos: Decio Tozzi e Luiz Carlos Ramos

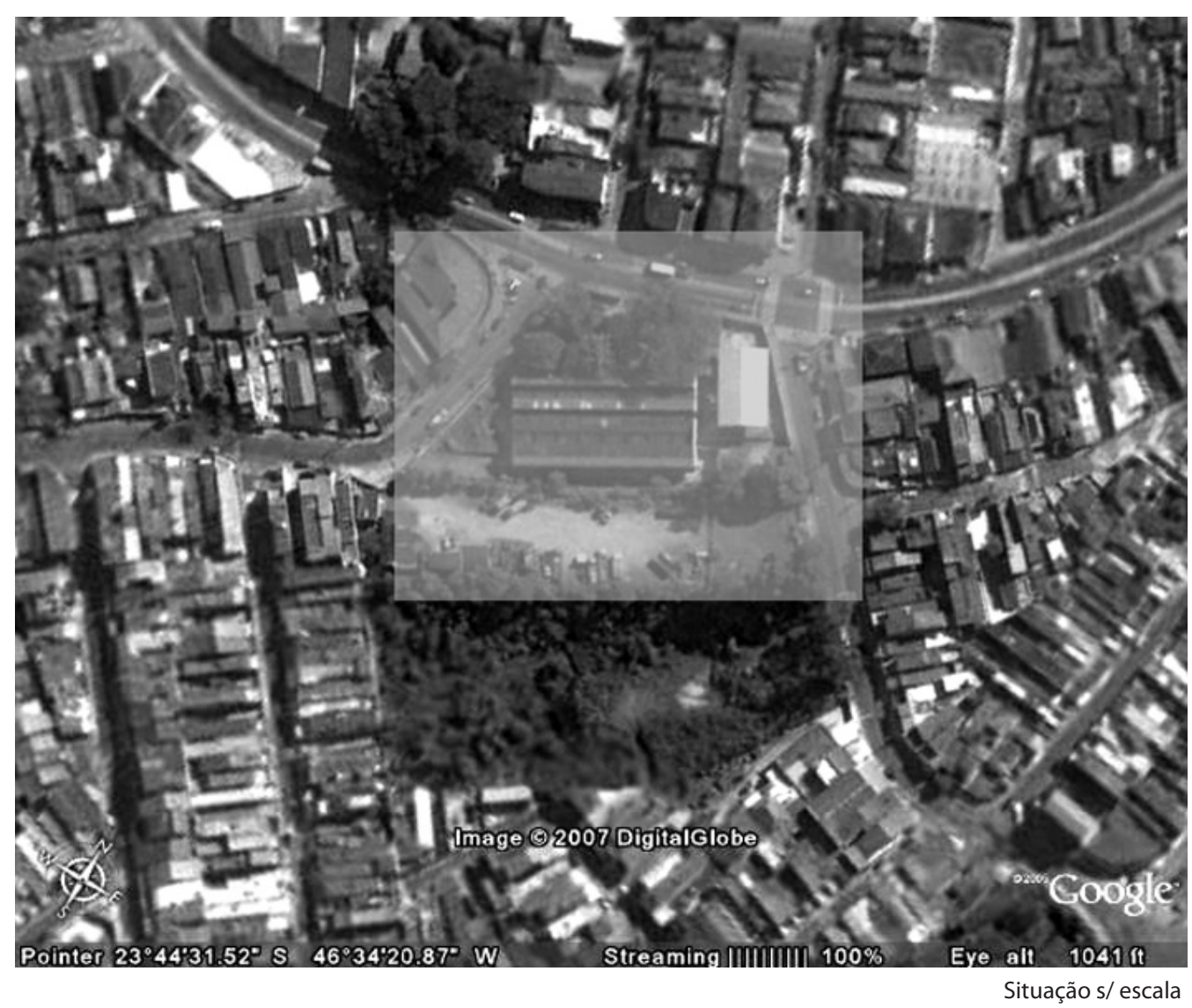



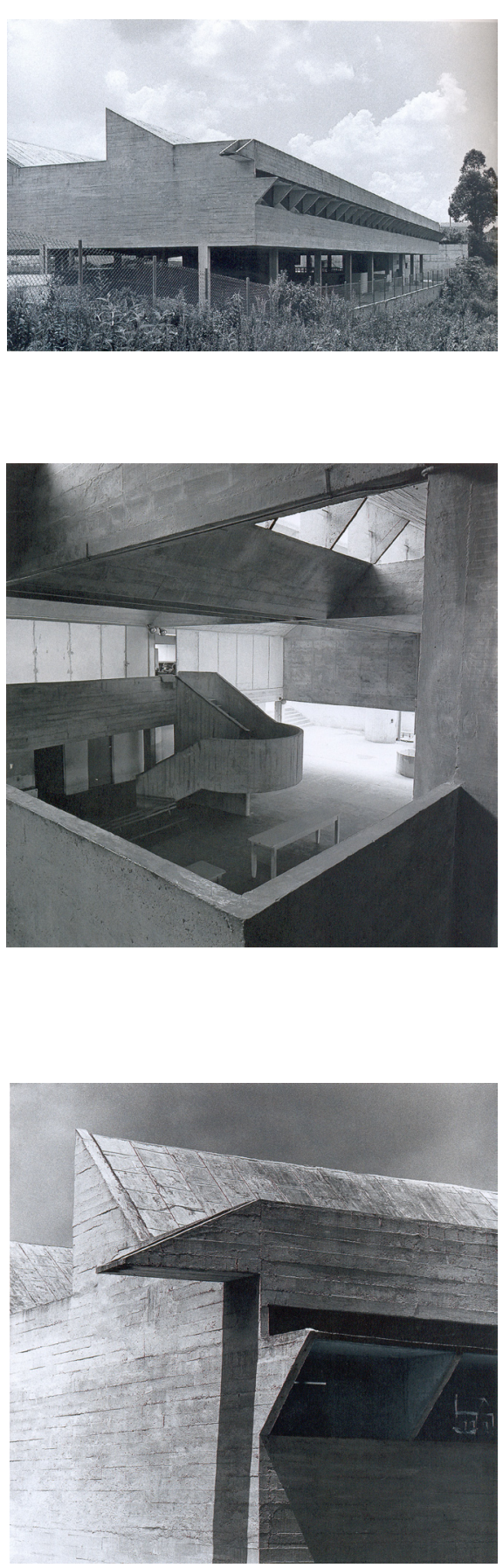

Essa obra retoma a discussão iniciada pelo arquiteto Vilanova Artigas em Itanhaém e Guarulhos: o espaço central coberto para onde voltam-se as diferentes funções da escola. O térreo era absolutamente aberto, integrando interior e exterior de maneira franca. Os únicos ambientes nesse piso eram banheiros, zeladoria, cozinha e refeitórios.

O pavimento superior, dividido em duas alas paralelas e separadas pelo vazio, abriga na face noroeste acesso administrativo, administração, médico, dentista e duas salas de aula do pré-primário e na face sudeste, as oito salas de aula destinadas ao primário. Uma ponte comunica as duas alas passando sobre o vazio. Além dela, três escadas complementam a composição do vazio e conectam os pisos, cada uma com uma forma e dimensões peculiares. A maior delas conecta a varanda de circulação das salas do primário ao pátio coberto, outra, menor, também em dois lances liga as salas do pré-pirmário ao respectivo pátio e a terceira, helicoidal, o bloco administrativo ao piso inferior.

Praticamente toda a construção foi executada em concreto armado aparente: a estrutura (uma série de pórticos equidistantes), as paredes de fechamento das salas em painéis pré-moldados, os armários sob os caixilhos de vidro das salas de aula, os peitoris e os bancos moldados "in loco" (que em quase toda a extensão das galerias de circulação substituem os guarda-corpos, agregando a estas a função de estar).

Como em todas as outras obras agrupadas nesse catálogo, a cobertura dessa escola é plana e impermeabilizada. Suas aberturas em forma de "sheds" ou lanternins (como nas fábricas do entorno) garantem uma iluminação homogênea do espaço central.

Outro aspecto interessante desse edifício são as rampas de acesso, cujo patamar de entrada fica a meio caminho dos pisos da escola. Uma das rampas direciona o acesso à escola e a outra, ao pátio, de modo a permitir usos concomitantes dos espaços. Acima, as dependências de uso mais "restrito" e abaixo, os usos mais ligados à comunidade. Os bancos do pátio coberto sugeriam o uso desses espaços abertos para aulas ao ar livre.. Segundo TOZZI (2007), naquele momento a arquitetura acompanhava o avanço pedagógico:"Essa era a liberdade sonhada por todos os teóricos como Anísio Teixeira. Na minha opinião, não há como fazer arquitetura escolar sem pensar na possibilidade plena da Pedagogia" (informação verbal)'. 
Infelizmente o térreo foi fechado e com ele o acesso da população ao centro da escola. Os espaços destinados ao lazer, à recreação e às aulas ao ar livre já não existem mais. De todo modo as aberturas zenitais ainda conferem ao interior da construção escolar uma certa luz...
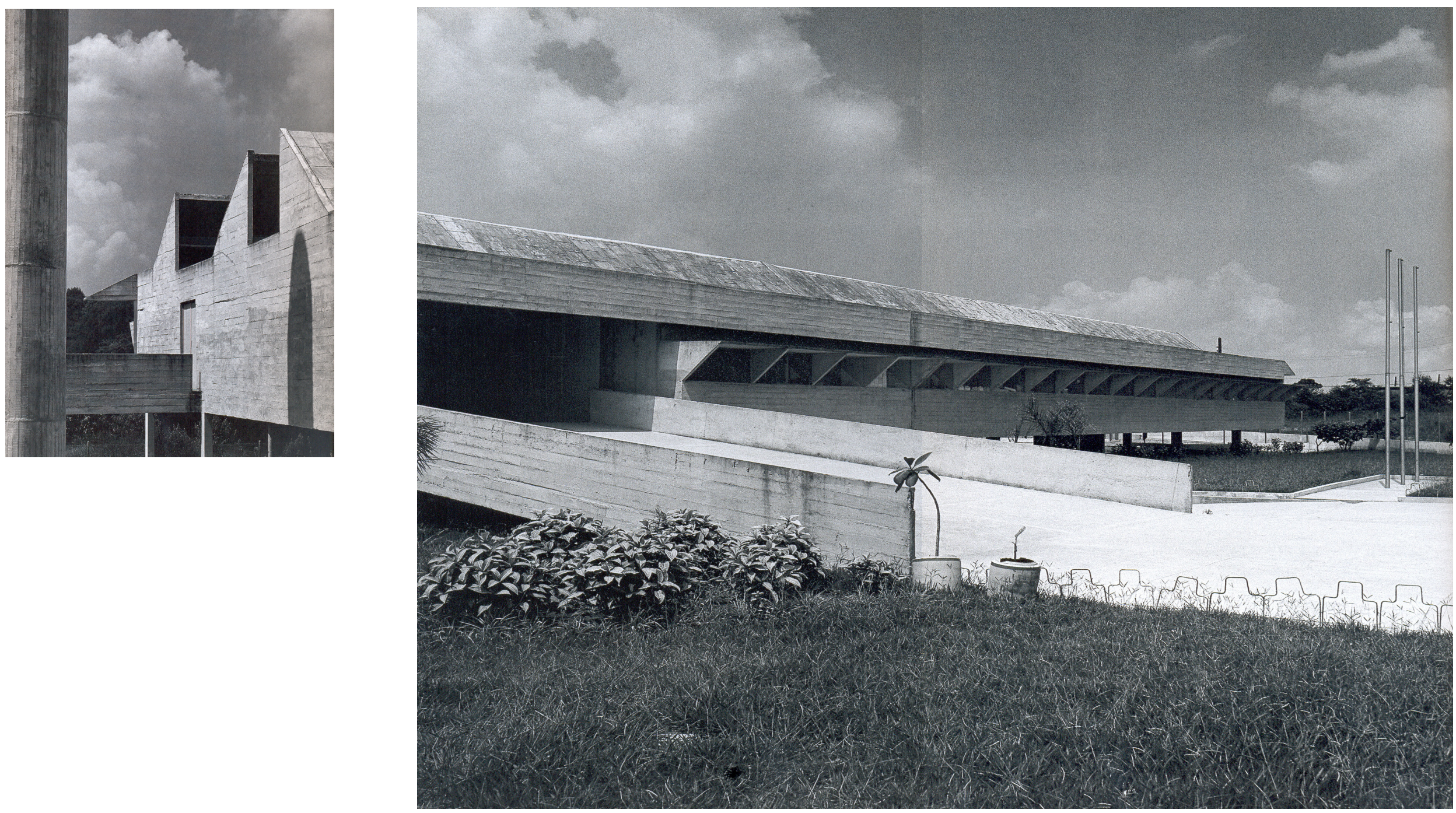

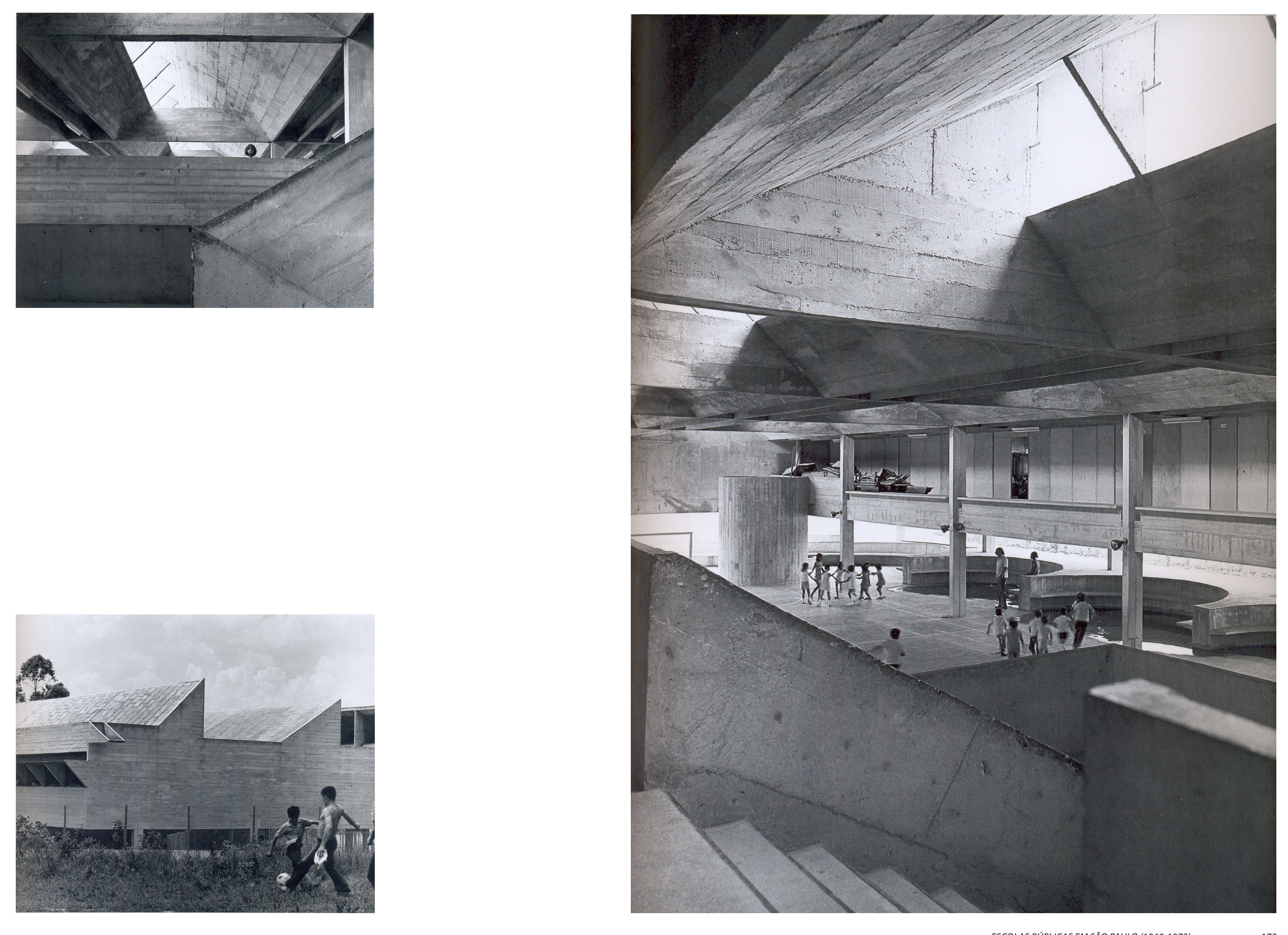


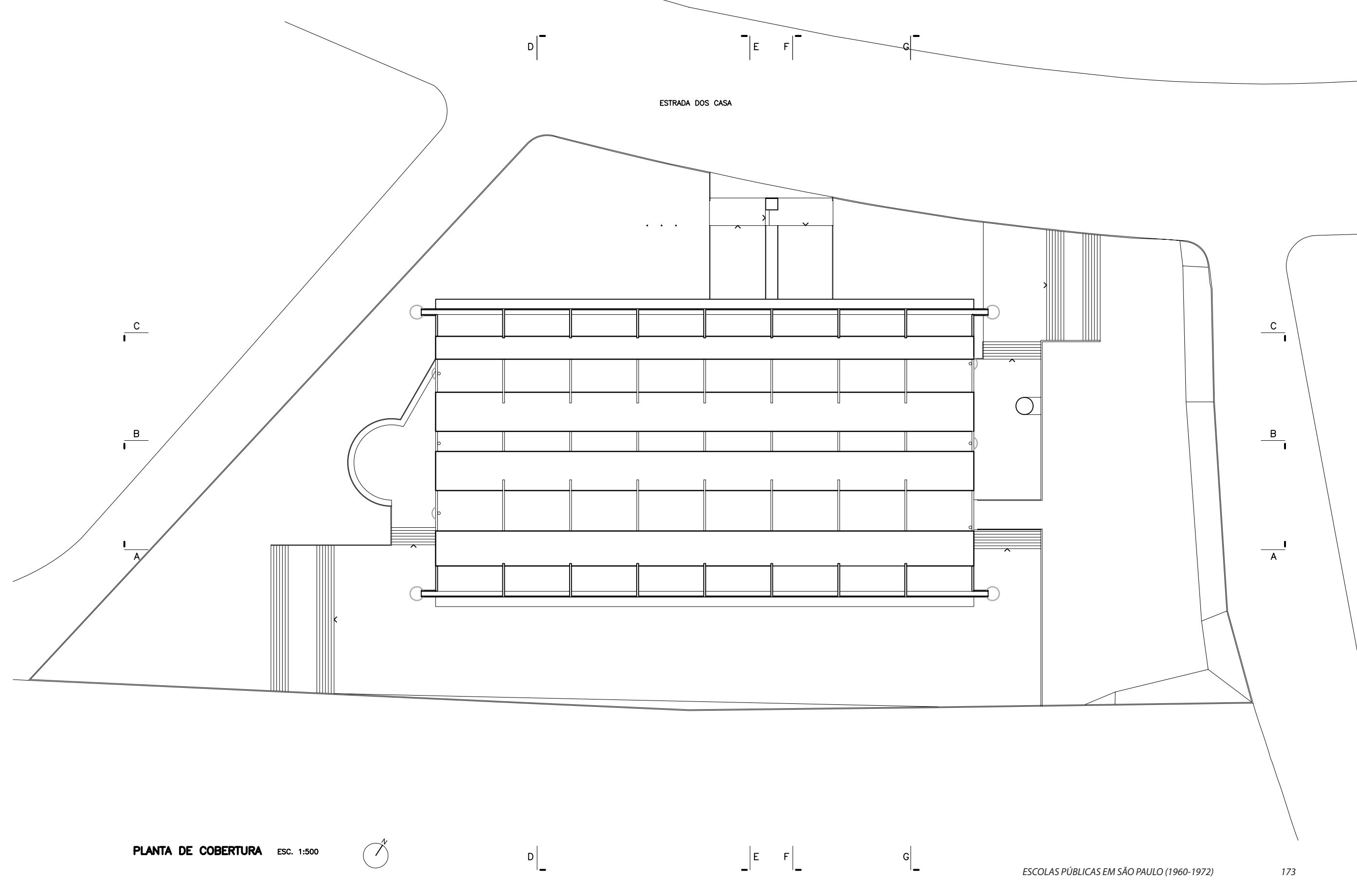




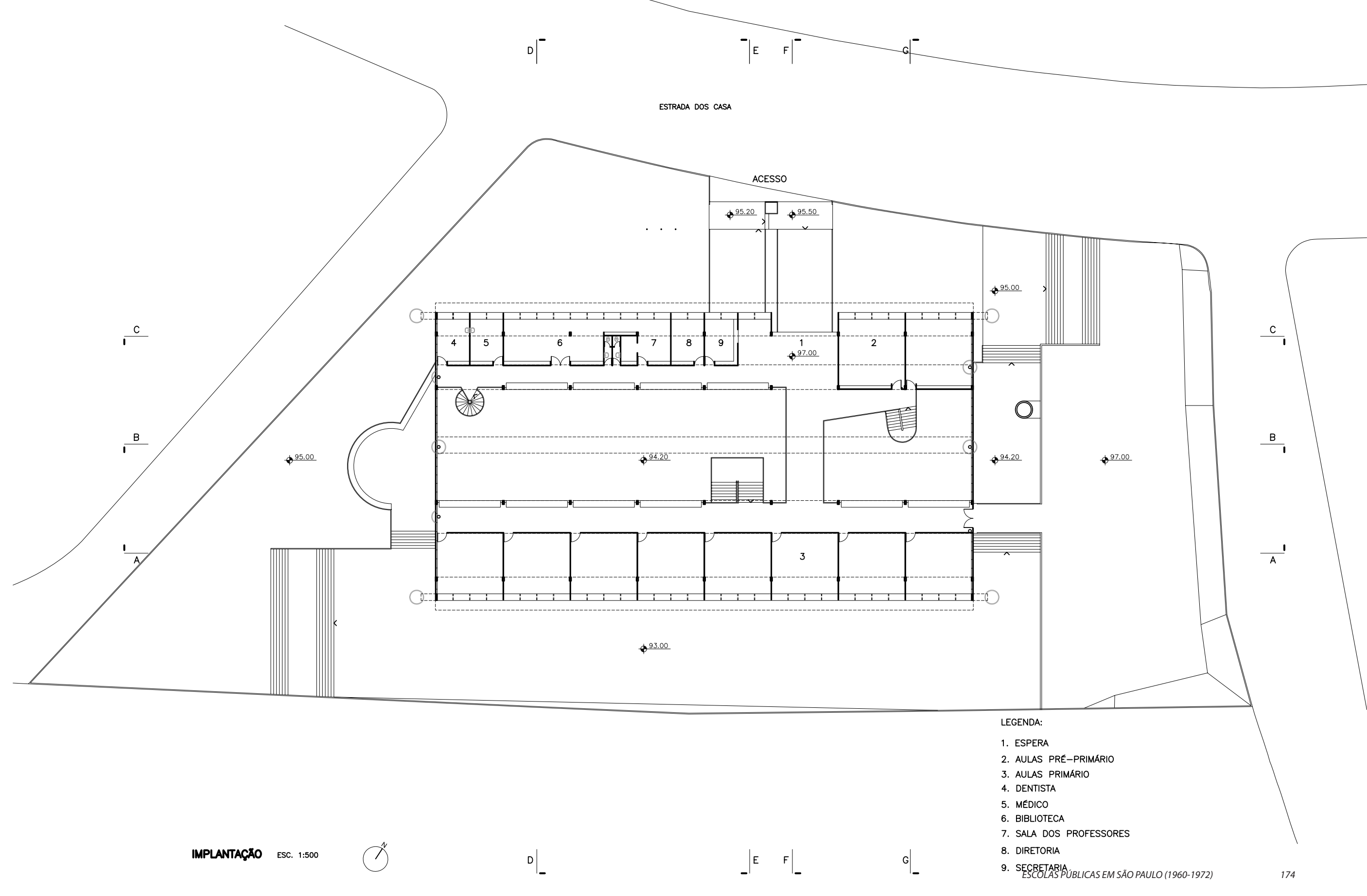




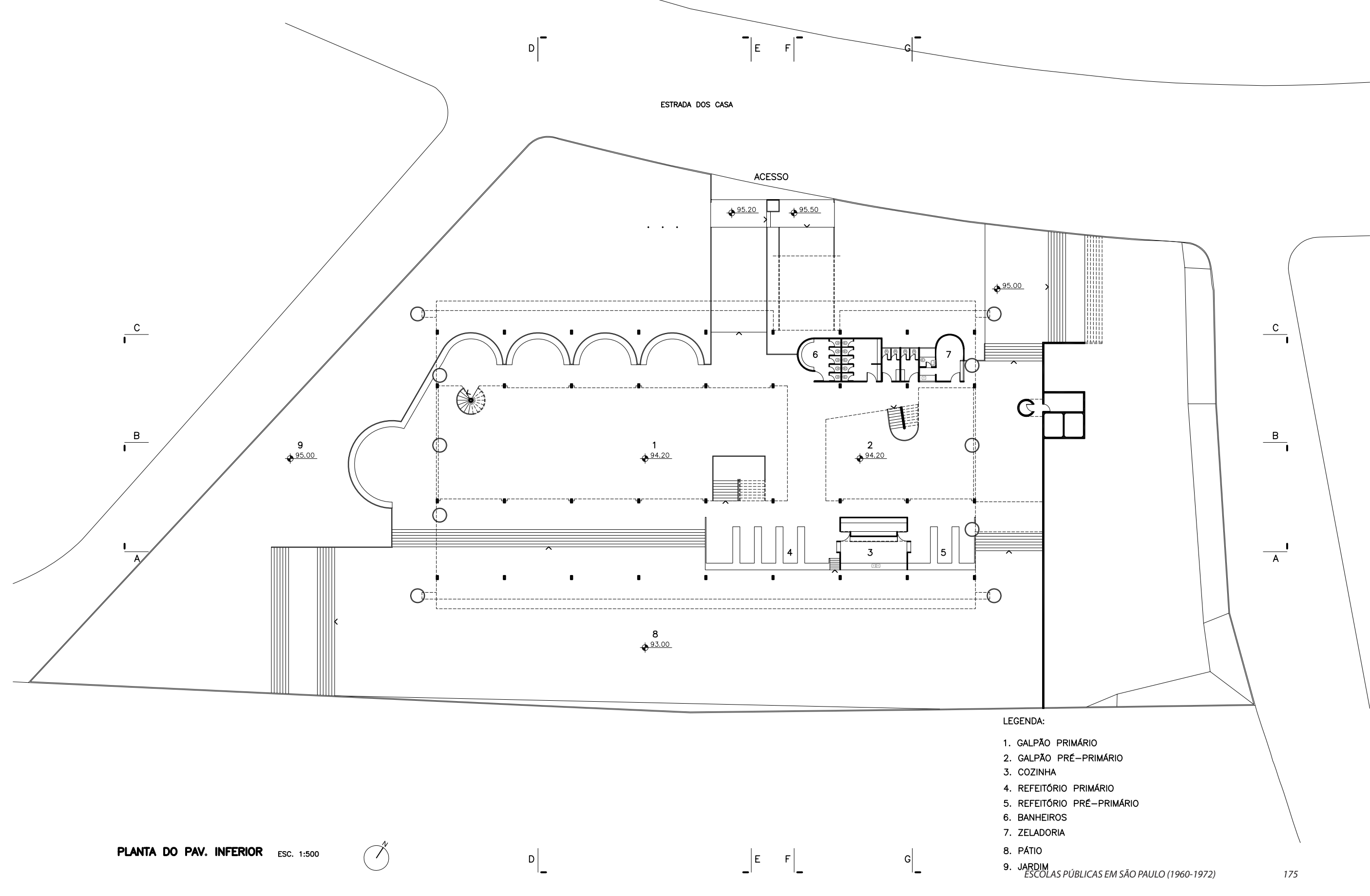



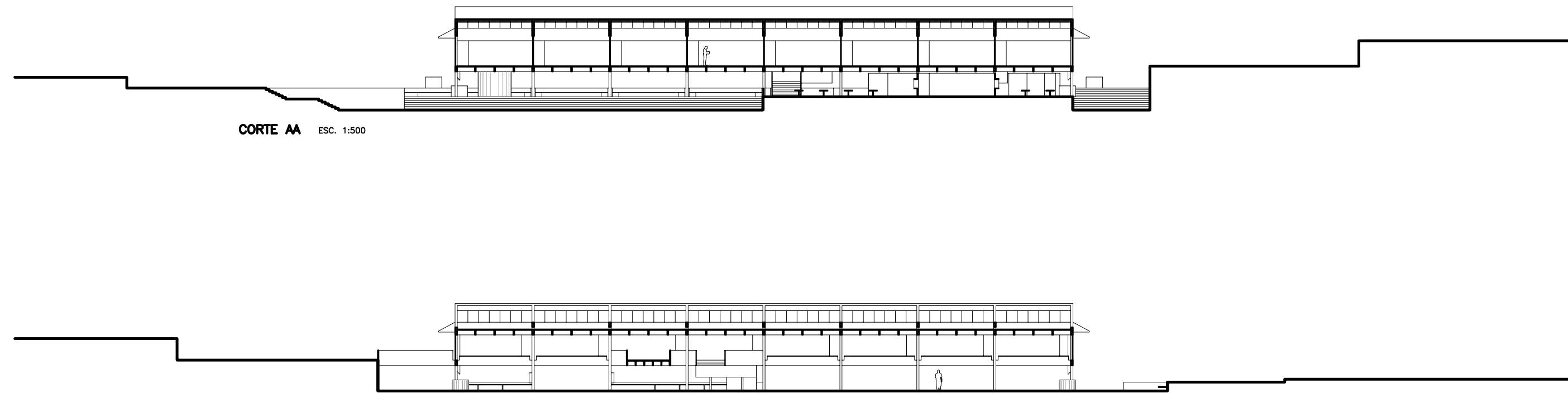

CORTE BB ESC. 1:500

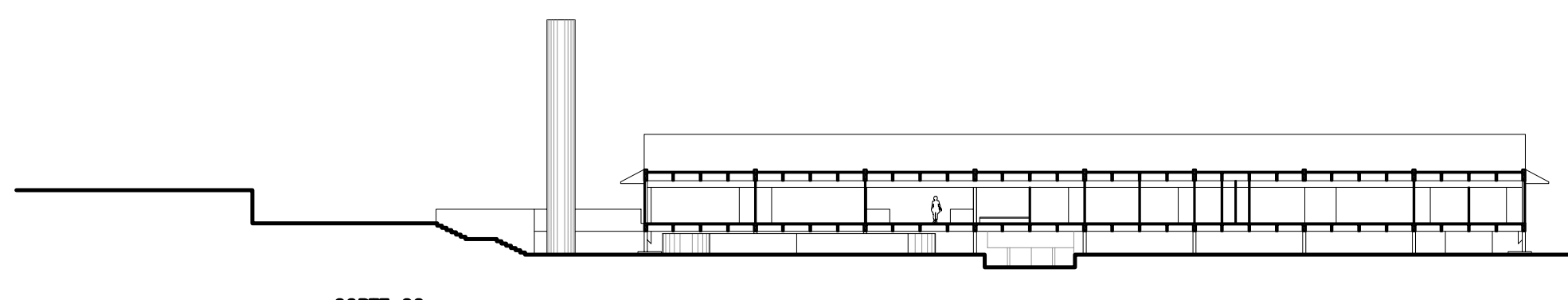

CORTE CC ESC. 1:500 


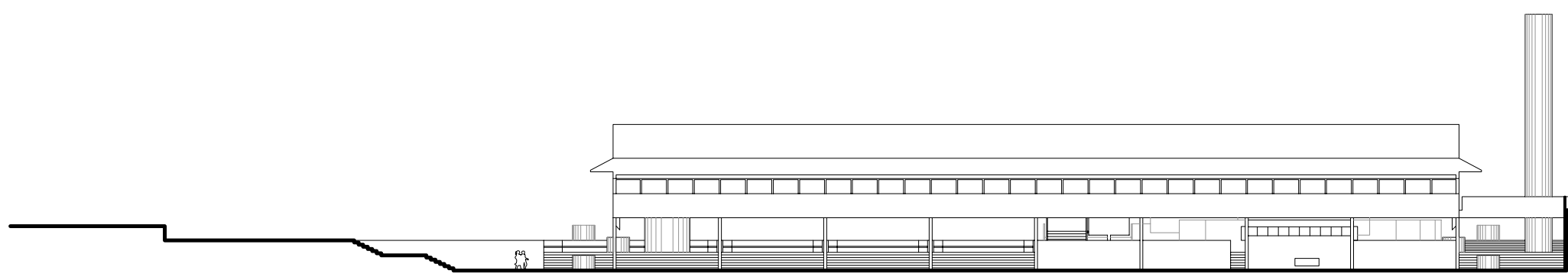

ELEVAÇAO NORTE ESC. 1:500

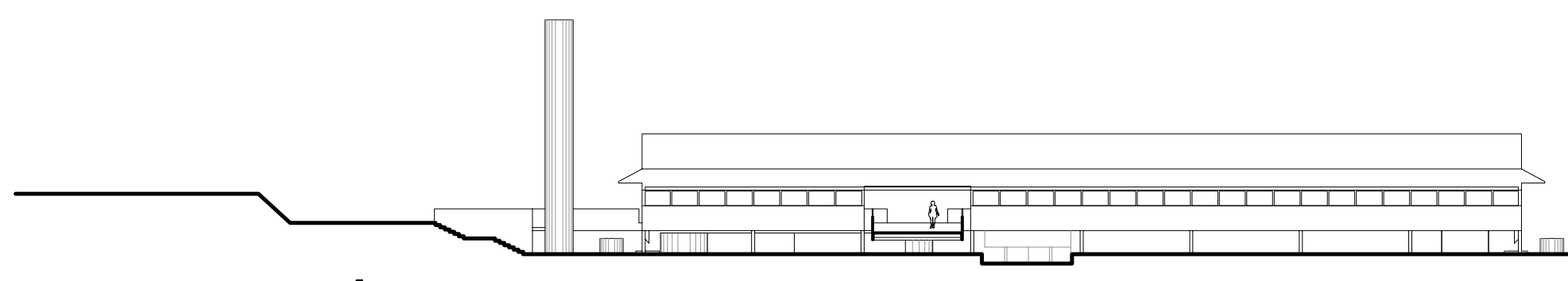

ELEVACAO SUL ESC. 1:500 


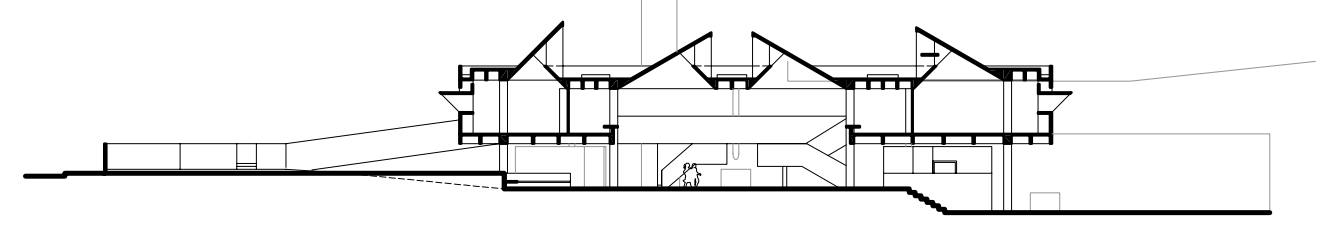

CORTE DD ESC. 1:500
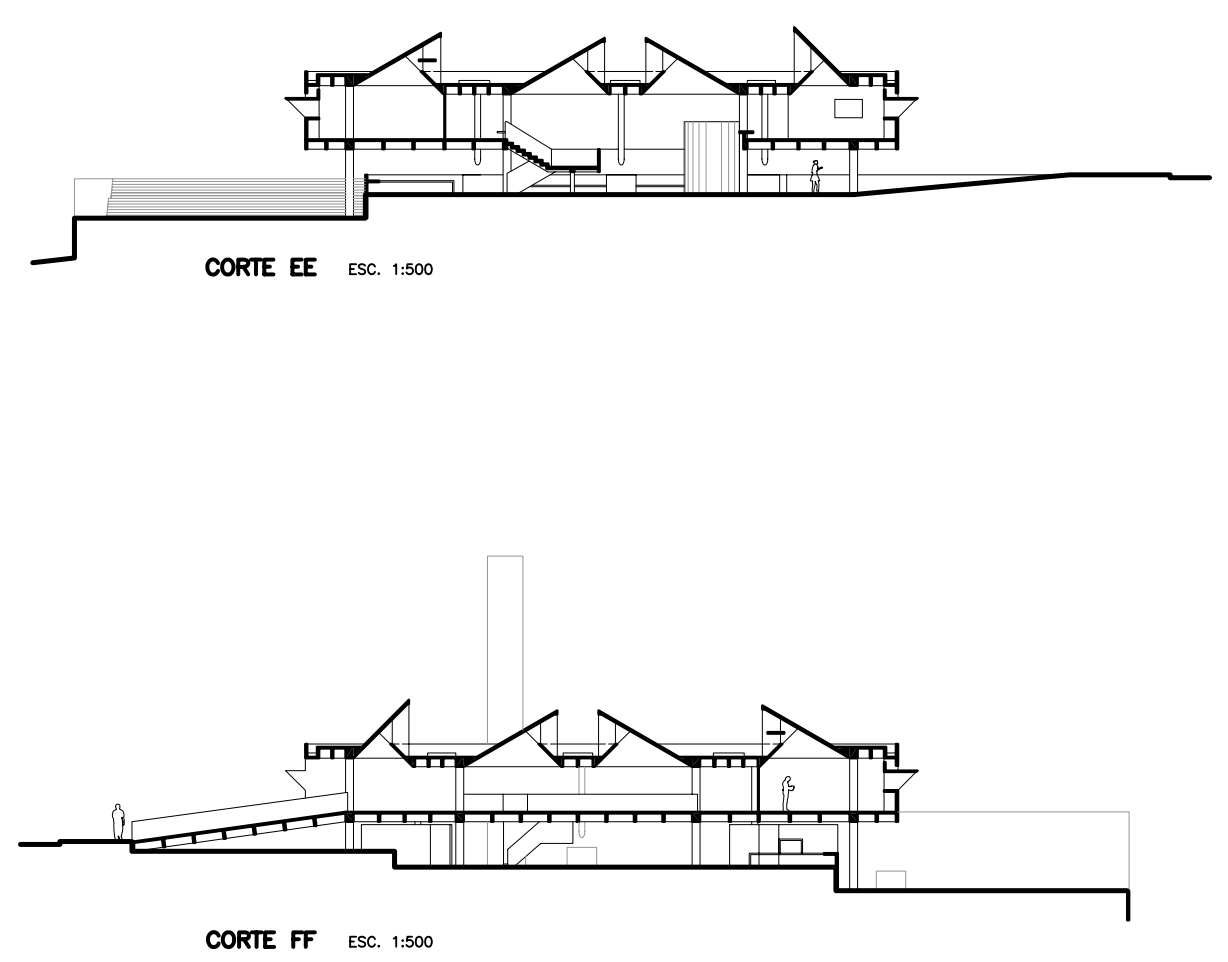

CORTE FF ESC. 1:500

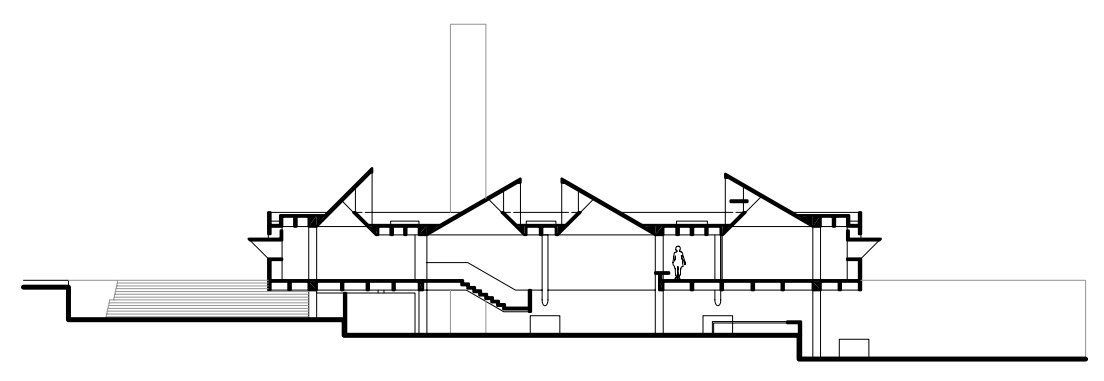

CORTE GG ESC. 1:500
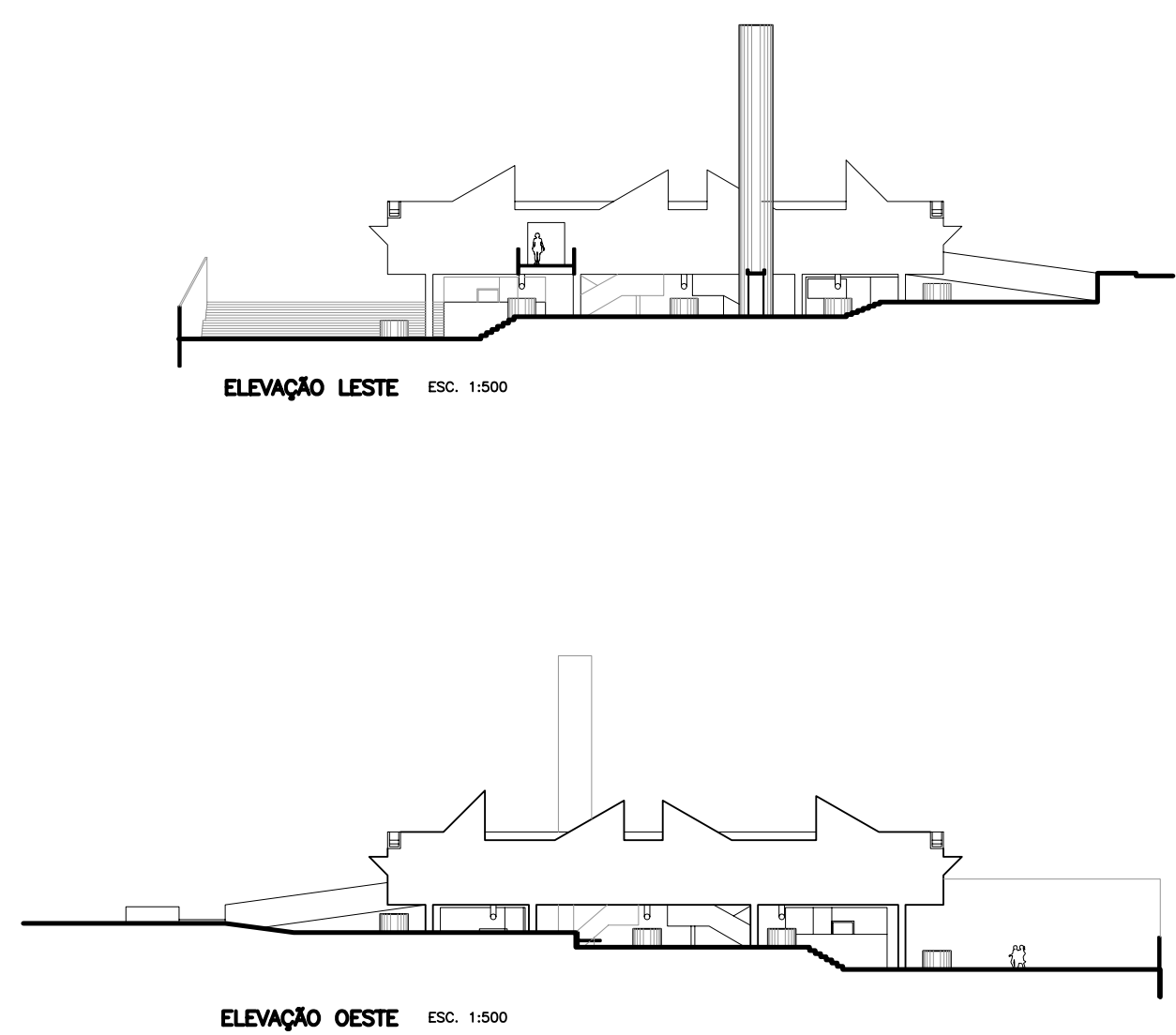

ESCOLAS PÚBLICAS EM SÃO PAULO (1960-1972) 

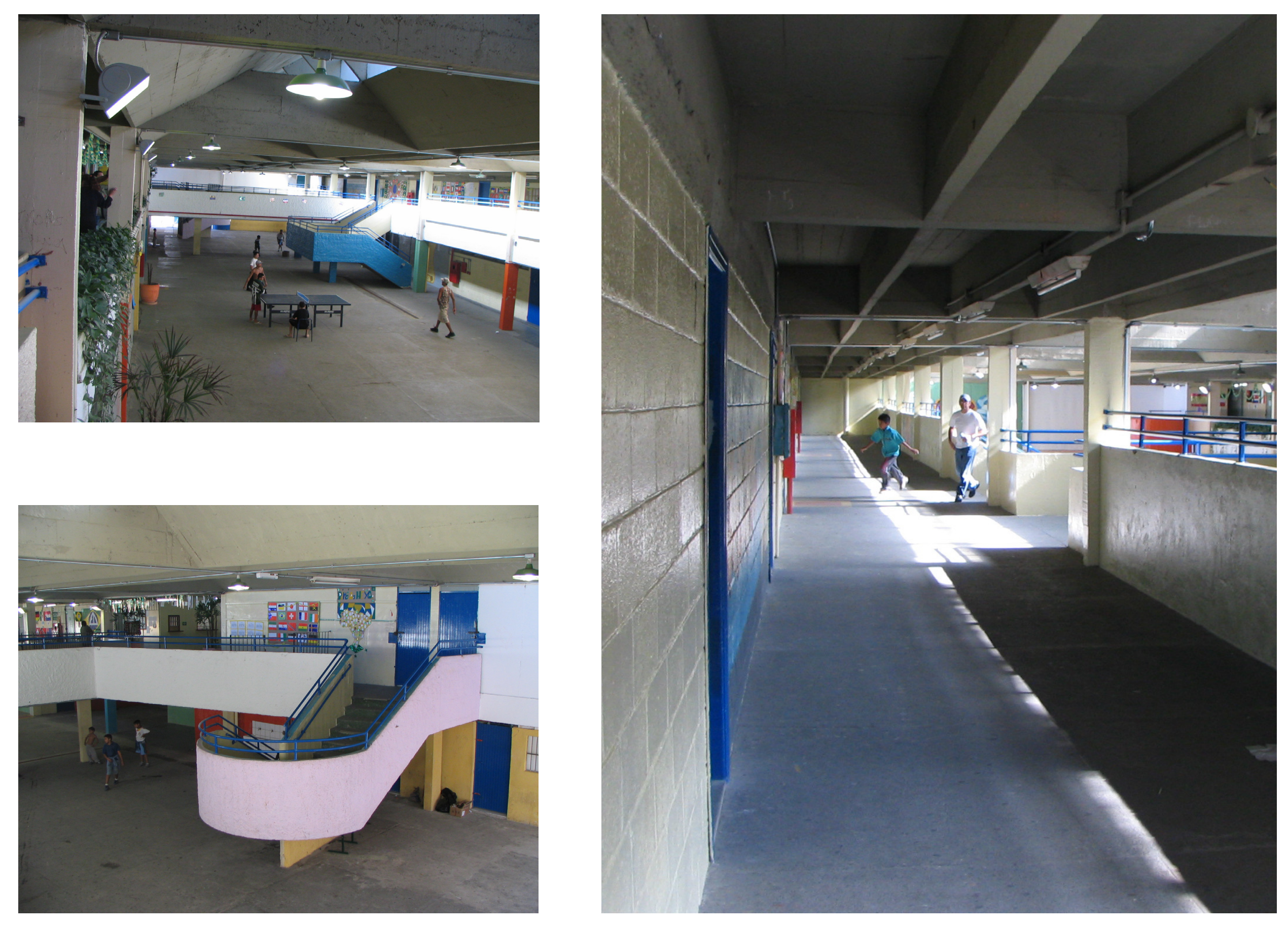


\section{Considerações finais}

Em1964, (re)início de uma era ditatorial no país, Artigas foi afastado da FAUUSP, preso e exilado no Uruguai. Em 1967 voltou à mesma faculdade para proferir a aula inaugural. Na época havia a expectativa de que ele fizesse críticas à ditadura militar em seu discurso. Mas, frustrando a maioria dos presentes, Artigas leu um belíssimo texto que versava sobre o conteúdo semântico da palavra "desenho", entendido como desígnio, intenção, desejo. E convocou os estudantes a participarem desse universo rico de possibilidades poéticas: "Que catedrais tendes no pensamento?" 1 , perguntará no final do discurso. Desse modo, pareceu defender o papel do projeto como a "arma" mais efetiva de luta contra a dura realidade imposta.

Para espanto de muitos, ainda em 1967 projeta em parceria com os arquitetos Paulo Mendes da Rocha e Fábio Penteado (dentre outros) o Conjunto Residencial Zezinho Magalhães Prado, de iniciativa estatal. No final do ano de 1968 a promulgação do Ato Institucional no 5 (Al 5), que correspondeu a um acirramento do regime militar ao decretar o fechamento do Congresso Nacional, resultou em novo afastamento de Artigas da FAUUSP (bem como de outros professores, entre eles Paulo Mendes da Rocha). O Al 5 vigorou até 1978 e sua revogação permitiu a volta do arquiteto à universidade em 1979.

Filiado ao Partido Comunista, Artigas era um crítico do regime militar e ao mesmo tempo colocava seu trabalho a serviço do poder público vilipendiado pela truculência desse regime. Essa contradição acompanha a sua trajetória e a dos outros arquitetos que compõem esse acervo. Paulo Mendes da Rocha, Ubyrajara Gilioli, Paulo Bastos e Décio Tozzi aderiram aos ideais de ação prática defendidos por Artigas: mudar o que fosse possível ou aproximarse do ideal por meio da realização das obras. Assim, paradoxalmente, as escolas apresentadas neste trabalho serviram de propaganda política à ditatura militar sob a qual foram realizadas.

Entretanto essas mesmas escolas apontavam numa direção inversa ao da ideologia conservadora e repressiva da ditadura. Em contraposição ao fechamento operado pela autoritarismo, eram escolas essencialmente abertas à comunidade. Guardavam em seu bojo um desejo de transformação da sociedade através da qualificação dos espaços de usufruto coletivo. A exemplo do Núcleo de Educação Infantil do Jardim Calux e do Grupo Escolar de 1 ARTIGAS, Vilanova. O desenho. Apud FERRAZ, Marcelo (org.). Vilanova Artigas. São Paulo: Instituto Lina Bo e P. M. Bardi / Fundação Vilanova Artigas, 1997, p.136. 
Ferrazópolis, o pátio de recreação, com suas aberturas zenitais ("aberturas para o céu", ROCHA, 1970²), eram valorizados como espaço do convívio, das relações interpessoais, das festas, enfim, do exercício da cidadania. As escolas, assim "abertas", funcionavam como antídoto ao regime.

Além disso eram, como a EMEB Mário Martins Almeida, centros de referência urbana nos locais periférios em que muitas vezes foram implantadas. Todas elas podem ser reconhecidas à distância. Tinham e ainda hoje têm lugar de destaque na paisagem. A escola na praça da era republicana de certa forma foi substituída pela praça na escola pública. Arquitetura desenhando cidade:

"Muito já se falou sobre o caráter introvertido desses projetos da "escola paulista”, como que a afirmar uma voluntária recusa da cidade em nome da constituição de um espaço urbano recriado, como um "laboratório" interno. Mas não podemos esquecer a generosa implantação desses edifícios, que fazem o piso do entorno fluir "naturalmente" para dentro dos seus espaços, sem portas nem entradas hierarquicamente definidas, incorporando a cidade quase que imperceptivelmente nesses lugares de excelência. Pode-se dizer, assim, que é um partido decididamente urbanístico que define tais projetos.”3

Das onze escolas desse acervo apenas uma está em estado razoável de conservação. As outras dez encontramse em situação lastimável. Além dos muros que as separam das calçadas, foram gradeadas, tiveram os térreos fechados, como na escola de Ferrazópolis e no Jardim Ipê. Em muitas delas o concreto aparente foi pintado e repintado seguidas vezes, como na de Vila Maria em São José dos Campos, que expunha em sua superfície as marcas de sua construção. As lajes planas foram cobertas com telhados convencionais, impedindo que a luz do céu ilumine seu interior.

Esperamos, com esse trabalho, poder contribuir para a constituição desse importante acervo de escolas públicas, de modo a poder amparar, no exercício da reflexão crítica, a prática do projeto e a conservação da arquitetura que interessa em São Paulo e no país.

"A discussão sobre a importância do estado em criar monumentos que reafirmem o seu papel diante da sociedade era e é grande. Todas as sociedades, das mais simples às mais complexas, têm um ethos, que é tributário do que é vivido e pensado. Nesse sentido, os membros de uma sociedade sabem reconhecer as construções que fazem parte (ou não) do seu patrimônio. 
A natureza das relações do cidadão (substantivo que deriva do nome do pai) é fruto dos valores e das contradições da sua sociedade. São elas, as contradições, que podem despertar consciências e percepções críticas sobre o que deve ser preservado, sobre o que deve ser transformado ou, mesmo, sobre o que pode deixar de existir para abrir um novo espaço para a

comunidade. ${ }^{4}$

4 SILVA, Janice Theodoro da A construção da cidadania e da escola nas décadas de 1950 e 1960 . In: FERREIRA, Avany de Francisco; MELLO, Mirela Geiger (organizadoras). Arquitetura Escolar Paulista: anos 1950 e 1960. Fundação para o Desenvolvimento da Educação (FDE), São Paulo, 2006, p. 57. 


\section{Crédito das llustrações}

\section{Capítulo 1}

Página 06: FERREIRA, Avany De Francisco, MELLO, Mirela Geiger de. 2006. Arquitetura Escolar Paulista - Anos 1950 e 1960. São Paulo, Fundação para o Desenvolvimento da Educação.

Páginas 09, 10: DUARTE, Hélio de Queiroz. 1951. “O problema escolar e a arquitetura” Revista Habitat n. 4. São Paulo, Habitat Editora Ltda.

Páginas 23, 24: CAVALCANTI, Lauro. 2001. Quando o Brasil era moderno: guia de arquitetura 1928/1960. Rio de Janeiro, Aeroplano.

Páginas 7, 11, 12, 13, 14, 15, 16, 17, 18, 19, 20, 21, 22: FRANCK, Klaus (org.). 1960. Affonso Eduardo Reidy: buten und projekte. Basel, Verlag Gerd Hatje Stuttgart.

Páginas 25, 26, 27: PAPADAKI, Stamo (org.). 1956. Oscar Niemeyer: Work in Progress. New York, Reinhold Publishing Corporation.

\section{Capítulo 2}

Página 36: BOESIGER, W. 1951.Richard Neutra: Buildings and Projects. Editions Girsberger, Zurique.

Páginas 44, 45, 56: FERRAZ, Marcelo. 1997. Vilanova Artigas. São Paulo, Instituto Lina Bo e P. M. Bardi / Fundação Vilanova Artigas.

Páginas 45, 48: FERREIRA, Avany De Francisco, CORRÊA, Maria Elizabeth Peirão, MELLO, Mirela Geiger de. 1998. Arquitetura Escolar Paulista - Restauro. São Paulo, Fundação para o Desenvolvimento da Educação.

Páginas 35, 38: FERREIRA, Avany De Francisco, MELLO, Mirela Geiger de. 2006. Arquitetura Escolar Paulista Anos 1950 e 1960. São Paulo, Fundação para o Desenvolvimento da Educação. 
Páginas 47, 48, 49: KAMITA, João Masao. 2000. Vilanova Artigas. São Paulo, Cosac\&Naify Edições (Espaços da Arte Brasileira).

Páginas 34, 35: MINDLIN, Henrique. 2000.Arquitetura Moderna no Brasil.2a edição.Rio de Janeiro: Aeroplano Editora/ IPHAN.

Página 53, 54, 56: VALENTIN, Fábio Rago. 2003Casas para o Ensino: as Escolas de Vilanova Artigas. Dissertação de Mestrado FAUUSP.

Página 39: Acrópole no 307, junho de 1964.

Página 40: Acrópole no 316, abril de 1965.

Página 40: Acrópole no 318, junho de 1965.

Página 39: Acrópole n 342, agosto de 1967.

Página 55: Acrópole no 377, setembro de 1970.

Página 41: Acervo do escritório de Pedro Paulo Saraiva.

Páginas 43, 45, 46, 47, 48, 49, 50, 51, 52, 55: Biblioteca FAUUSP.

Páginas 29, 30, 31, 32, 33, 37: Habitat no 4, setembro/ dezembro de 1951.

\section{Capítulo 3}

Página 78: FERREIRA, Avany De Francisco, MELLO, Mirela Geiger de. 2006. Arquitetura Escolar Paulista - Anos 1950 e 1960. São Paulo, Fundação para o Desenvolvimento da Educação.

Páginas 126, 137, 152: GILIOLI, Ubyrajara. 1995. Arquitetura e Lugar. Tese de Doutorado- FAUUSP. 
Páginas 117, 118: SPIRO, Anette 2002. Paulo Mendes da Rocha: bauten und projekte. Zürich, Verlag Niggli AG, Sulgen.

Páginas 118, 119: XAVIER, Alberto; LEMOS, Carlos A. C.; CORONA, Eduardo. 1983. Arquitetura moderna paulistana. São Paulo, Pini.

Páginas 170, 171, 172: TOZZI, Decio. 2005. Arquiteto Decio Tozzi. São Paulo, D’Áuria Editora.

Páginas 94, 95, 96: Acrópole nº 342, agosto de 1967.

Página 70: Acrópole n 343, setembro de 1967.

Páginas 123, 124: Acrópole no 365, setembro de 1969.

Páginas 59, 60, 61, 70, 71, 80, 81, 82, 92, 93, 100, 101, 115, 116: Acervo do escritório de Paulo Mendes da Rocha.

Páginas 123, 125, 135, 136: Acervo do escritório de Ubyrajara Gilioli.

Páginas 160, 161, 162: Acervo do escritório de Paulo Bastos.

Páginas 58, 69, 79, 91, 99, 114, 122, 134, 150, 159, 169: Trechos de imagens de satélite extraídas do Google Earth.

Páginas 68, 90, 97, 98, 110, 111, 112, 113, 120, 121, 133, 146, 147, 148, 149, 168, 179: Carlos Augusto Ferrata (arquivo pessoal). 


\section{Bibliografia}

ABREU, Ivanir Reis Neves. 2007. Convênio Escolar: Utopia Construída. Dissertação de Mestrado- FAUUSP.

ACAYABA, Marcos. 2007. Marcos Acayaba. Textos de Hugo Segawa, Julio Roberto Katinsky, Guilherme Wisnik. São Paulo, Cosac Naify.

ACAYABA, Marlene Milan \& FISHER, Sylvia. 1979. Arquitetura Moderna Brasileira. São Paulo, Projeto.

ACAYABA, Marlene Milan. 1986. Residências em São Paulo: 1947-1975. São Paulo, Projeto.

AMADEI, José. 1951. “O que é Convênio Escolar” Revista Habitat n. 4. São Paulo, Habitat Editora Ltda.

ARGAN, Giulio Carlo. 1992. Arte Moderna. São Paulo, Companhia das Letras,

. 1966. El Concepto del Espacio Arquitetonico. Buenos Aires, Nueva Vision.

. 1984. Gropius e a Bauhaus. Lisboa, Presença.

1992. História da Arte como História da Cidade. São Paulo, Martins Fontes.

2000. Projeto e Destino.São Paulo, Editora Ática.

ARTIGAS, Rosa. 2003. "Biografia de Vilanova Artigas". Vilanova Artigas- catálogo da exposição realizada no Instituto Tomie Ohtake.

(org). 2000. Paulo Mendes da Rocha. São Paulo, Cosac\&Naify; Associação Brasil 500 anos Artes Visuais;

Fundação Bienal de São Paulo.

ARTIGAS, João Batista Vilanova.1958. "Revisão crítica de Niemeyer” [XAVIER 1987 pp 224 e 225.] . 1960. “Ginásio Estadual de Guarulhos”. In: Revista Acrópole n. 258. São Paulo, Max Gruenwald \& Cia. . 1961. “Ginásio de Itanhaem”. In: Revista Acrópole n. 271. São Paulo, Max Gruenwald \& Cia. . 1962. “Ginásio Estadual de Guarulhos”. In: Revista Acrópole n. 281. São Paulo, Max Gruenwald \& Cia. 1970a. “Sobre escolas.... In: Revista Acrópole n. 377. São Paulo, Max Gruenwald \& Cia, set/.

. 1970b. "Plantas de escolas paulistas". In: Revista Acrópole n. 377. São Paulo, Max Gruenwald \& Cia.

. 1974. "Contribuição para o relatório sobre o ensino de arquitetura UIA - UNESCO 1974". In: Revista

Caramelo n. 06. 1993. São Paulo, FAU-USP.

. 1986. Caminhos da Arquitetura. São Paulo, Fundação Vilanova Artigas/ Pini, 2a Edição.

. 1989. A Função Social do Arquiteto. São Paulo, Fundação Vilanova Artigas/ Nobel.

BARDI, Lina Bo. 1951. "Primeiro: escolas". In: Revista Habitat n. 4. São Paulo, Habitat Editora Ltda.

BARROS, Edgard Luiz de. 1991. O Brasil de 1945 a 1964. São Paulo, Contexto. 
BARROS, Roque Spencer Maciel de. 1960. Diretrizes e bases da educação. São Paulo, Pioneira. BENÉVOLO, Leonardo. 1976. História da Arquitetura Moderna. São Paulo, Perspectiva.

BENJAMIN, Walter. 1987.Magia e Técnica, Arte e Política, trad.port., SP, Brasiliense, (Obras escolhidas 1).

BOESIGER, W. 1951.Richard Neutra: Buildings and Projects. Editions Girsberger, Zurique.

BONDUKI, Nabil (org.). 1999. Affonso Eduardo Reidy. São Paulo, Lisboa: Instituto Lina Bo e P. M. Bardi e Editotial Blau.

BONDUKI, Nabil. 1992. Construindo Territórios de Utopia. Rio de Janeiro, Fase.

1998. Origens da Habitação Social no Brasil - Arquitetura Moderna, Lei do Inquilinato e Difusão da Casa Própria. São Paulo, Estação Liberdade / Fapesp.

BOTEY, Josep Ma. 1996 Oscar Niemeyer - Obras e projetos. Barcelona, Editorial Gustavo Gili.

BRANDÃO, Carlos Rodrigues. 1985. O que é Educação. São Paulo, Editora Brasiliense, 2a . Edição.

BRITO, Alfredo; NOBRE, Ana Luíza; XAVIER, Alberto. 1991. Arquitetura Moderna no Rio de Janeiro. São Paulo, Eva/Pini.

BRUAND, Yves. 1981. Arquitetura Contemporânea no Brasil. São Paulo, Perspectiva.

CAMARGO, Mônica Junqueira. Joaquim Guedes. 2000. São Paulo, Cosac\&Naify Edições, (Espaços da Arte Brasileira).

CANDIDO, Antônio. O Discurso e a Cidade. São Paulo, Duas Cidades.

CAVALCANTI, Lauro. 2001. Quando o Brasil era Moderno: Guia de Arquitetura 1928/1960. Rio de Janeiro, Aeroplano.

CHAUÍ, Marilena, 1986. Conformismo e Resistência. Aspectos da cultura popular no Brasil, SP, Brasiliense. CONDURU, Roberto. 2000. Vital Brasil. São Paulo, Cosac\&Naify Edições, (Espaços da Arte Brasileira). CORONA, Eduardo. 1970. “Uma Exposição perdida” Revista Acrópole n. 377. São Paulo, Max Gruenwald \& Cia, set.

CORONA, Eduardo e Lemos, Carlos A. Cerqueira. 1972. Dicionários da Arquitetura Brasileira. São Paulo, Ed.

EDART.

CORRÊA, Maria Elizabeth Peirão, MELLO, Mirela Geiger de, NEVES, Helia Maria Vendramini. 1991. Arquitetura Escolar Paulista 1890-1920. São Paulo, Fundação para o Desenvolvimento da Educação.

CORRÊA, Maria Luiza. 1998. Artigas: da idéia ao desenho. Dissertação de mestrado. São Paulo. FAUUSP. 
COSTA, Lúcio. Lúcio Costa. 1995. Registro de uma Vivência. São Paulo, Empresa das Artes. 1962. Sobre Arquitetura. Porto Alegre, CEUA.

DUARTE, Hélio de Queiroz. 1951a. “O problema escolar e a arquitetura” Revista Habitat n. 4. São Paulo, Habitat Editora Ltda.

. 1951b. “A arquitetura do Convênio Escolar” In: Revista Habitat n. 4. São Paulo, Habitat Editora Ltda. . 1973. Escolas classe - Escola Parque: uma experiência educacional. São Paulo, FAUUSP.

FERRAZ, Marcelo. 1993. Lina Bo Bardi. São Paulo, Instituto Lina Bo e P. M. Bardi. . 1997. Vilanova Artigas. São Paulo, Instituto Lina Bo e P. M. Bardi / Fundação Vilanova Artigas.

FERREIRA, Avany De Francisco, CORRÊA, Maria Elizabeth Peirão, MELLO, Mirela Geiger de. 1998. Arquitetura Escolar Paulista - Restauro. São Paulo, Fundação para o Desenvolvimento da Educação.

FERREIRA, Avany De Francisco, MELLO, Mirela Geiger de. 2006. Arquitetura Escolar Paulista - Anos 1950 e 1960. São Paulo, Fundação para o Desenvolvimento da Educação.

FRAMPTON, Kenneth. 1997. História Crítica da Arquitetura Moderna. São Paulo, Martins Fontes.

FRANCASTEL, Pierre. 1988. Art et technique aux xix e txx éme. Siecles, Paris, Gallimard.

FRANCK, Klaus (org.). 1960. Affonso Eduardo Reidy: buten und projekte. Basel, Verlag Gerd Hatje Stuttgart. FREIRE, Paulo. 1983.A Pedagogia do Oprimido. São Paulo, Editora Paz e Terra, 13a. Edição. GILIOLI, Ubyrajara. 1995. Arquitetura e Lugar. Tese de Doutorado- FAUUSP.

GRAEF, Edgard A. 1995. Arte e Técnica na Formação do Arquiteto. São Paulo, Fundação Vilanova Artigas / Nobel. GREGOTTI, Vitório. 1978.Território da Arquitetura. São Paulo, Perspectiva.

HOLLANDA, Sérgio Buarque de. 1957. Caminhos e fronteiras. Rio de Janeiro, José Olympio (Documentos brasileiros, v. 89).

1995. Raízes do Brasil. São Paulo, Cia das Letras.

KAMITA, João Masao. 2000. Vilanova Artigas. São Paulo, Cosac\&Naify Edições (Espaços da Arte Brasileira).

KATINSKY, Júlio Roberto 1998. apresentação. Anistia na FAUUSP: a reintegração dos professores cassados pelo AI-5. São Paulo, FAU.

KOPP, Anatole. 1990. Quando o moderno não era um estilo e sim uma causa. São Paulo, Nobel/Edusp.

LEMOS, Carlos A. C. Lemos. 1990. Arquitetura Brasileira. São Paulo, Edições Melhoramentos/ Editora da Universidade de São Paulo. 
1981. O que é patrimônio histórico, SP, Brasiliense.

LIMA, Mayumi Watanabe de Souza. 1995. Arquitetura e Educação. São Paulo, Studio Nobel.

MARCÍllO, Maria Luiza. 2005. História da Escola em São Paulo e no Brasil. São Paulo, Imprensa Oficial do Estado de São Paulo : Instituto Fernand Braudel.

MEYER, Regina Prosperi. 1991. Metrópole e Urbanismo, São Paulo anos 50.Tese de doutoramento, FAUUSP MINDLIN, Henrique. 2000.Arquitetura Moderna no Brasil.2 a edição.Rio de Janeiro: Aeroplano Editora/ IPHAN. MORSE, Richard. 1970. Formação Histórica de São Paulo. São Paulo, Difusão Européia do Livro.

PAPADAKI, Stamo (org.). 1956. Oscar Niemeyer: Work in Progress. New York, Reinhold Publishing Corporation.

PENTEADO, Fábio. 1970. “Vilanova Artigas, construtor de escolas” In: Revista Acrópole n. 377. São Paulo, Max

Gruenwald \& Cia, set.

PIÑON, Hélio. 2002. Paulo Mendes da Rocha. São Paulo, Romano Guerra Editora.

ROCHA, Paulo Mendes da. “Edifícios escolares: comentários” In: Revista Acrópole n. 377. São Paulo, Max

Gruenwald \& Cia, set/ 1970.

, "Imagem do Brasil", Caramelo n.4, SP, GFAU, 1992.

SINGER, Helena. 1997.República de Crianças, São Paulo, Hucitec.

SINGER, Paul. 1968. Desenvolvimento econômico e evolução urbana. São Paulo, Nacional.

SOLOT, Denise Chini. 2004. Paulo Mendes da Rocha: estrutura o êxito da forma. Rio de Janeiro, Viana\&Mosley.

SKIDMORE, Thomas. 1975. Brasil: De Getúlio a Castelo. Rio de Janeiro, Paz e Terra.

SILVA, Helena Aparecida Ayoub. Conceitos, Processos e Métodos Presentes na Elaboração do Projeto de Arquitetura.

1998. Dissertação de Mestrado- FAUUSP.

SPIRO, Anette 2002. Paulo Mendes da Rocha: bauten und projekte. Zürich, Verlag Niggli AG, Sulgen.

TEIXEIRA, Anísio1951. “Um presságio de progresso” . Revista Habitat n. 4. São Paulo, Habitat Editora Ltda.

. 1999. “Educação no Brasil”. Rio de Janeiro, Editora UFRJ.

. 2000. "Pequena Introdução à Filosofia da Educação: A Escola Progressiva ou a Transformação da Escola”. Rio de Janeiro, DP\&A.

2005. “Educação e o Mundo Moderno”. Rio de Janeiro, Editora UFRJ.

TELLES, Sophia Silva. 1988. Arquitetura moderna no Brasil: o desenho da superfície. Dissertação de mestrado. São Paulo, FFLCH da Universidade de São Paulo. 
1990. "Museu da Escultura” In: Arquitetura e Urbanismo. São Paulo, Pini.

THOMAZ, Dalva Elias. 1997.Um olhar sobre Vilanova Artigas e sua contribuição à Arquitetura Brasileira. Dissertação de mestrado FAUUSP.

TOLEDO, Benedito Lima de. 1967. Prestes Maia e as Origens do Urbanismo Moderno em São Paulo. São Paulo, Empresa das Artes,1996. São Paulo.

. 1983. São Paulo: Três Cidades em um século. 2. Ed.aum. São Paulo, Duas Cidades.

TOZZI, Decio. 2005. Arquiteto Decio Tozzi. São Paulo, D’Áuria Editora.

VALENTIN, Fábio Rago. 2003Casas para o Ensino: as Escolas de Vilanova Artigas. Dissertação de Mestrado FAUUSP. WISNIK, Guilherme. 2001. Lúcio Costa. São Paulo, Cosac\&Naify Edições,

WOLFF, Silvia Ferreira Santos. 1992.Espaço e Educação - Os primeiros passos das escolas pública paulistas. São Paulo, Dissertação de mestrado - Faculdade de Arquitetura e Urbanismo da USP.

XAVIER, Alberto (org). 1987. Depoimentos de uma geração. São Paulo, ABEA/FVA/PINI.

XAVIER, Alberto; LEMOS, Carlos A. C.; CORONA, Eduardo. 1983. Arquitetura moderna paulistana. São Paulo, Pini.

sd. Projetos de Arquitetura Escolar - FECE, Tema - 3. Impresso - 1. São Paulo, Fundo Estadual de Construções Escolares.

1936. Novos Prédios para Grupo Escolar (Estudos da Directoria do Ensino e da Directoria de Obras Públicas). São Paulo. Secretaria da Educação e Saúde Publica.

1973. “Novos Rumos da Arquitetura Escolar”. In: Revista Dirigente Construtor n. 08, São Paulo, junho.

2003. Vilanova Artigas- catálogo da exposição realizada no Instituto Tomie Ohtake.

\section{Periódicos}

ACRÓPLE. São Paulo, Max Gruenwald \& Cia,

AU/ARQUITETURA E URBANISMO. São Paulo, PINI

HABITAT. São Paulo, Habitat

MÓDULO. Rio de Janeiro, Avenir

PROJETO. São Paulo, Projeto

PROJETO/ DESIGN. São Paulo, Arco 